\author{
UNIVERSIDADE DE SÃO PAULO \\ FACULDADE DE ZOOTECNIA E ENGENHARIA DE ALIMENTOS
}

GISELE LOURENÇO DA APARECIDA MAKISHI

Propriedades de soluções filmogênicas e de filmes de gelatina ou colágeno com extrato de boldo-do-Chile

PIRASSUNUNGA

2016 
GISELE LOURENÇO DA APARECIDA MAKISHI

Propriedades de soluções filmogênicas e de filmes de gelatina ou colágeno com extrato de boldo-do-Chile

Tese apresentada à Faculdade de Zootecnia e Engenharia de Alimentos da Universidade de São Paulo, como parte dos requisitos para obtenção do título de Doutor em Ciências do programa de pósgraduação em Engenharia de Alimentos.

Área de Concentração: Ciências da Engenharia de Alimentos

Orientador: Prof. Dr. Paulo José do Amaral Sobral

PIRASSUNUNGA

2016 
Dados Internacionais de Catalogação na Publicação

Serviço de Biblioteca e Informação da Faculdade de Zootecnia e Engenharia de Alimentos da Universidade de São Paulo

Makishi, Gisele Lourenço da Aparecida

M235p Propriedades de soluçōes filmogênicas e de filmes de gelatina ou colágeno com extrato de boldo-doChile / Gisele Lourenço da Aparecida Makishi ; orientador Paulo José do Amaral Sobral. -Pirassununga, 2016. $154 \mathrm{f}$.

Tese (Doutorado - Programa de Pós-Graduação em Engenharia de Alimentos) -- Faculdade de Zootecnia e Engenharia de Alimentos, Universidade de Săo Paulo.

1. biopolimeros. 2. Peumus boldus. 3. filmes ativos. 4. compostos fenólicos. 5. propriedades fisicas. I. Sobral, Paulo José do Amaral, orient. II. Titulo. 


\section{Propriedades de soluções filmogênicas e de filmes de gelatina ou colágeno com extrato de boldo-do-Chile}

Tese apresentada à Faculdade de Zootecnia e Engenharia de Alimentos da Universidade de São Paulo, como parte dos requisitos para obtenção do título de Doutor em Ciências do programa de pós-graduação em Engenharia de Alimentos.

Área de concentração: Ciências da Engenharia de Alimentos

Aprovada em: 18 de março de 2016

BANCA EXAMINADORA

Prof. Dr. Paulo José do Amaral Sobral Orientador FZEA/USP

Prof. Dr. João Borges Laurindo Universidade Federal de Santa Catarina

Dra. Milena Martelli Tosi FFCLRP/USP

Profa. Dra. Alessandra Lopes de Oliveira FZEA/USP 
Dedico aos meus pais José Carlos (sempre no coração) e Izilda, Fausto, meus afilhados, minha família e meus amigos 


\section{AGRADECIMENTOS}

Diante de uma grande conquista, sempre temos muito que agradecer:

Agradeço primeiramente à Deus, por todas as oportunidades que colocou em minha vida, e por sempre providenciar o melhor.

Agradeço à minha mãe, Izilda, por todo suporte ao longo desses anos para que eu pudesse me dedicar integralmente às minhas atividades no doutorado.

Agradeço ao meu marido Fausto Makishi, pelo amor, companheirismo e parceria ao longo de todos esses anos, essa conquista também é sua, obrigada por fazer parte da minha história.

Ao meu orientador Paulo Sobral, agradeço à confiança em mim depositada em todos estes anos de trabalho, obrigada por todo apoio profissional e pessoal.

Agradeço a Fundação CAPES pela concessão da bolsa de doutorado (cota - demanda social), também à FAPESP pela concessão da bolsa de doutorado (2013/09417-1) e pela concessão da Bolsa Estágio de Pesquisa no Exterior (BEPE) (2014/21136-0), e ao CNPq pela concessão da Bolsa de Desenvolvimento Tecnológico Industrial - Nível B que permitiram a dedicação exclusiva à este trabalho.

O que seria de mim sem minha amiga Emily Amorim (Ly), anjo que Deus colocou na minha vida, obrigada pelo apoio, pela ajuda na finalização da formatação da tese, pelas palavras de força, risadas e por me mostrar que Deus é fiel sempre. Você e sua família moram no meu coração.

Minha amiga-irmã-professora Luciana Felício ( $\mathrm{Lu}$ ) sempre cuidou de mim e me ajudou nas horas difíceis. Obrigada pelos conselhos, por ser uma boa amiga, e por todo carinho e atenção.

Minha amiga-irmã Débora Santos, obrigada por tudo, a história da nossa amizade se confunde com nossa vida acadêmica, os bancos do ZEA nunca mais serão os mesmos.

Meus queridos e essenciais Carla Luciano (Kakau), Flávia Vargas, Lucas Arantes e Tiara Gomes, quanto suporte e parceria envolvidos, vocês são especiais, só tenho a dizer: MUITO OBRIGADA!!!!

Agradeço aos meus estagiários David Bertan, Karen Arantes, Patrícia Costa e Roberta Kuniyoshi, sem vocês a realização de trabalho não seria possível.

A equipe do Laboratório de Tecnologia de Alimentos, minha segunda casa durante esses anos, meu muito obrigada 
Aos demais amigos da pós-graduação Nayla Souki, Vitor Garcia, Josiane Borges, Camila Bitencourt, Cristian Flaker e Natali Valadão agradeço pela amizade e pelos bons momentos que passamos juntos.

Agradeço aos amigos da vida que sempre foram pacientes e entenderam minhas ausências: Luana Alves, Graciele Boareto, Michele Corat e Marcelo Marçal, Guilherme e Daniela Carneiro, Melissa Selaysin, Carol Silva, Bianca Franzini, Guilherme e Susana Costa, Sirlei Carvalho, Haenae Ament, Amanda Figueiredo, Marcela e Emília Scherma.

Aos técnicos Ana Mônica Bittante, Rodrigo Lourenço, Roseli Lacerda, Carla Lourenço e Guilherme Silva agradeço pela prestatividade e paciência em ensinar.

Agradeço à Profa Perla Relkin (AgroParis Tech) pela oportunidade de realização do intercâmbio, bem como à Profa Marie Noëlle Maillard e o técnico Even Le Roux pelo auxílio com as análises cromatográficas. Além disso, agradeço toda equipe da AgroParis Tech Massy pela cordialidade, respeito e atenção com que fui recebida.

Aos meus companheiros de laboratório na AgroParis Tech, pela amizade, companheirismo e generosidade Gaëlle Petite, Monique Miaranalisoa Randrianarivo, Jenny Wu, Samira Fernandes Nassar e Bezaye Taye.

Meu muito obrigada aos professores do Departamento de Engenharia de Alimentos (ZEA), em especial, Samantha Pinho, Rosemary Carvalho, Alessandra Lopes, Izabel Moraes, Cynthia Ditchfield, Rogers Ribeiro, Fernanda Vanin e Vivian Lara.

Agradeço à minha família, meus irmãos, cunhadas e sobrinhos pela paciência, entendimento, respeito e carinho, em especial, ao meu irmão Gilberto e sua esposa Carminha pelo suporte financeiro para que esse sonho pudesse se concretizar.

Meu muito obrigada mais cheio de amor e carinho aos meus afilhados Tales, Isadora e Beatriz, sua existência por si só me faz abençoada e muito mais feliz.

Meu muito obrigada à equipe da Academia Vida, Deisi, Norma, Audrey, Alex, Michel, Rafael, Anderson (em memória), Thais, Bruna e Tia Cris, esse lugar foi o refúgio para o alívio do estresse diário.

Agradeço à todos os funcionários da Faculdade de Zootecnia e Engenharia de Alimentos, o bom desempenho de suas funções nos permitem realizar nosso trabalho de forma tranquila.

Agradeço à todos que de alguma forma contribuíram para realização deste trabalho,

Muito Obrigada, 
"L'avenir a plusieurs noms: pour les faibles, il se nomme l'inaccessible. Pour les peureux, il se nomme l'inconnu. Pour les courageux, il se nomme opportunité". (Victor Hugo)

"Que ninguém se engane, só consigo a simplicidade através de muito trabalho".

(A hora da estrela - Clarice Lispector) 


\section{RESUMO}

Filmes à base de biopolímeros podem ser utilizados para produção de embalagens ativas, que além de proteger os alimentos, podem interagir com o produto. No caso de embalagens ativas com atividade antioxidante, tem-se privilegiado o uso de agentes antioxidantes naturais, considerando-se que o uso de antioxidantes sintéticos tem sido questionado, sobretudo em relação à sua inocuidade. Existem muitos extratos de plantas já conhecidos por sua atividade antioxidante, que têm sido utilizados com frequência em estudos de filmes à base de biopolímeros, não somente por serem ricos em polifenóis, mas principalmente por sua boa interação com a matriz polimérica. O extrato de boldo-do-Chile (Peumus boldus) possui atividade antioxidante comprovada, entretanto, não existem relatos sobre sua adição em filmes. Dessa forma, o objetivo geral desta tese foi o desenvolvimento de filmes à base de colágeno ou gelatina adicionados de extrato de boldo-do-Chile, com propriedades físicas e funcionais para seu emprego como embalagens bioativas. Foram realizadas as caracterizações (fenólicos totais, ABTS, DPPH, cor, ${ }^{\circ}$ Brix e pH) do extrato aquoso de boldo-do-Chile, preparado em quatro diferentes temperaturas. Além disso, foram avaliadas as propriedades reológicas e térmicas da solução de gelatina, e também foram elaborados filmes com as soluções de gelatina e colágeno a partir de soluções filmogênicas com diferentes concentrações de macromoléculas e extrato de boldo. Esses filmes foram caracterizados para conhecimento de suas propriedades mecânicas (tração e perfuração), propriedades óticas (cor e opacidade), espessura, umidade e solubilidade em água. Uma concentração de macromoléculas foi escolhida para a realização de análises complementares, a saber: análises térmicas (DSC), cristalinidade por difração de raio $\mathrm{X}$ (DRX), permeabilidade ao vapor de água (PVA), microscopia eletrônica de varredura (MEV), brilho, espectroscopia de infravermelho com transformada de Fourier (FTIR), ângulo de contato, propriedades de barreira UV/Visível e atividade antioxidante. A adição do extrato de boldo-do-Chile nos filmes de gelatina e colágeno produziu filmes com atividade antioxidante, sem prejuízo às demais propriedades estudadas. Observou-se que o extrato aquoso de boldo-do-Chile apresentou propriedades antioxidantes, mas que foram dependentes da temperatura de extração. O extrato de boldo-do-Chile foi capaz de modificar as propriedades térmicas das soluções filmogênicas de gelatina, não sendo observado efeito nas análises reológicas. Por outro lado, o extrato aquoso de boldo-do-Chile não influenciou as propriedades mecânicas, solubilidade, umidade, cristalinidade e a permeabilidade ao vapor de água dos filmes de gelatina ou colágeno. Algumas propriedades térmicas sofreram 
efeito dos extratos, mas as análises de FTIR não mostraram a formação de novas interações. As propriedades óticas e de barreira UV/Visível foram influenciadas pelo extrato de boldodo-Chile, sendo que os filmes se apresentaram mais amarelados com o aumento da concentração do extrato de boldo-do-Chile. As micrografias mostraram filmes de gelatina bastante homogêneos e filmes de colágeno com superfícies mais rugosas. Os resultados de brilho e ângulo de contato corroboraram com estas respostas. Em conclusão, os filmes de ambas macromoléculas apresentaram atividade antioxidante, podendo dessa forma, serem considerados como filmes ativos.

Palavras-chave: Biopolímeros, Peumus boldus, filmes ativos, compostos fenólicos, propriedades físicas. 


\begin{abstract}
Biopolymers based films can be used for the production of active packaging, which in addition to protecting food, can interact with the product. In the case of active packaging with antioxidant activity, natural antioxidants has been privileged, considering the use of synthetic antioxidants has been questioned, especially in relation to their safety. There are many plant extracts known for their antioxidant activity, which have been frequently used in studies of biopolymers based films, not only for being rich in polyphenols, but particularly by their good interaction with the polymer matrix. The boldo extract (Peumus boldus) has antioxidant activity, however, there are no reports on its addition in films. Thus, the objective of this thesis was the development of collagen- or gelatin-based films adding boldo extract, and the analysis of their physical and functional properties for its use as bioactive packaging. The analysis (total phenolics, ABTS, DPPH, color, Brix and $\mathrm{pH}$ ) of the aqueous extract of boldo were realized under four diverse temperatures. Furthermore, rheological and thermal properties of gelatin solution were evaluated, and in addition, films were prepared with filmogenic solutions of gelatin and collagen in different concentrations of macromolecules and boldo extract. These films were characterized for understanding of their mechanical properties (tensile and puncture tests), optical properties (color and opacity), thickness, moisture and solubility in water. A concentration of macromolecules has been chosen to carry out further analysis, namely: thermal analysis (DSC), crystallinity by X-ray diffraction (XRD), water vapor permeabillity (WVP), scanning electron microscopy (SEM), gloss, Fourier transform infrared spectroscopy (FTIR), contact angle, UV / Visible barrier properties and antioxidant activity. The addition of boldo extract at gelatin and collagen films produced films with antioxidant activity, without prejudice to other properties studied. It was observed that aqueous extract of boldo presented antioxidant properties, but they were dependent on the extraction temperature. Boldo extract was able to modify the thermal properties of filmogenic solutions of gelatin, without effect on rheological analysis. Moreover, the aqueous extract of boldo did not influence the mechanical properties, solubility in water, moisture, crystallinity and water vapor permeability of films of gelatin or collagen. Some thermal properties were affected by extracts, although FTIR analysis did not show formation of new interactions. Optical and UV/Visible barrier properties were infuenced by the addition of boldo extraction, and the films presented had high yellowness with increasing concentration of boldo extract. The micrographs showed gelatin films quite homogenous and collagen films with rough surfaces. Gloss and the contact angle results
\end{abstract}


corroborated these answers. In conclusion, the films of both macromolecules have antioxidant activity and can, thus, be considered as active films.

Keywords: Biopolymers, Peumus boldus, active films, phenolic compounds, physical properties. 


\section{LISTA DE FIGURAS}

Figura 1: Esquema de classificação dos compostos fenólicos

Figura 2: Produção dos extratos de boldo-do-Chile (a) extração em banho termostatizado

(b) filtração do extrato. 35

Figura 3: Estrutura química e reação com um antioxidante. 37

Figura 4: Identificação dos poços segundo as diluições realizadas 40

Figura 5: Imagem de uma solução de colágeno com $2 \mathrm{~g}$ de colágeno/100g de SF 46

Figura 6: Representação gráfica da variação das cores para os parâmetros L*, a* e b* (CIELab) 49

Figura 7: Sistema célula+filme+sílica-gel utilizado nas determinações de permeabilidade ao vapor de água.

Figura 8: Ângulo de contato entre a gota e a superfície do sólido ..................................... 53

Figura 9: Amostra de extrato aquoso de boldo-do-Chile produzido à $45^{\circ} \mathrm{C}$........................ 59

Figura 10: Cores dos extratos de boldo-do-Chile produzidas utilizando os resultados da

Tabela 6 no Programa EasyRGB.

Figura 11: Curva do tempo de estabilização do extrato de boldo-do-Chile para a análise de DPPH.

Figura 12: Imagens das análises microbiológicas para o extrato de boldo-do-Chile produzido à $45^{\circ} \mathrm{C}$ (a) Escherichia coli, (b) Salmonella spp, (c) Staphylococcus aureus (d) Pseudomonas aeruginosa.

Figura 13: Imagens das análises microbiológicas para o extrato de boldo-do-Chile produzido à $60^{\circ} \mathrm{C}$ (a) Escherichia coli, (b) Salmonella spp, (c) Staphylococcus aureus (d) Pseudomonas aeruginosa.

Figura 14: Imagens das análises microbiológicas para o extrato de boldo-do-Chile produzido à $90^{\circ} \mathrm{C}$ (a) Escherichia coli, (b) Salmonella spp, (c) Staphylococcus aureus (d) Pseudomonas aeruginosa.

Figura 15: Cromatograma UHPLC-DAD-MS feito em modo electrospray positivo do extrato aquoso do boldo produzido à $30^{\circ} \mathrm{C}$.

Figura 16: Cromatograma UHPLC-DAD-MS feito em modo electrospray negativo do extrato aquoso do boldo produzido à $30^{\circ} \mathrm{C}$.

Figura 17: Exemplo de curva de varredura de deformação da solução de gelatina à $50^{\circ} \mathrm{C} 71$

Figura 18: Exemplo de curva de varredura de deformação da solução de gelatina à $5^{\circ} \mathrm{C} . .72$ 
Figura 19: Exemplo de curva de varredura de temperatura para a solução de gelatina elaborada com $8 \mathrm{~g} / 100 \mathrm{~g}$ de gelatina e $150 \mathrm{~g}$ de boldo/100g de gelatina.

Figura 20: Exemplo de curva de varredura de frequência para uma solução de gelatina elaborada com $8 \mathrm{~g} / 100 \mathrm{~g}$ de SF.

Figura 21: Exemplos de curvas de varredura de frequência para todas as concentrações de extrato de boldo-do-Chile.

Figura 22: Módulo de armazenamento - (G' em Pa) em função da variação da frequência para as diferentes concentrações de gelatina.

Figura 23: Curvas de fluxo das soluções com $2 \mathrm{~g}$ de gelatina/100g de SF (dados experimentais ajustados ao modelo Newtoniano)

Figura 24: Curvas de fluxo das soluções com $4 \mathrm{~g}$ de gelatina/100g de SF(dados experimentais ajustados ao modelo Newtoniano).

Figura 25: Curvas de fluxo das soluções com $6 \mathrm{~g}$ de gelatina/100g de SF ajustadas ao modelo Newtoniano

Figura 26: Curvas de fluxo das soluções com $8 \mathrm{~g}$ de gelatina/100g de SF ajustadas ao modelo Newtoniano.

Figura 27: Exemplo de evolução do módulo de perda - G” ao longo do tempo (5h)

Figura 28: Exemplo de termograma de uma solução 8g de gelatina/100g de solução filmogênica (_ temperatura ; ___ fluxo de calor) com uma isoterma à $5^{\circ} \mathrm{C}$ de 90minutos.

Figura 29: Exemplos da zona IV que foi integrada para obtenção da entalpia de fusão $(\Delta H$ $\mathrm{em} \mathrm{J/g)}$

Figura 30: Efeito da concentração de gelatina sobre a entalpia de fusão.

Figura 31: Entalpia de fusão $(\Delta \mathrm{H})$ para as soluções de gelatina em diferentes concentrações para isotermas à $5^{\circ} \mathrm{C}$ durante 30 minutos.

Figura 32: Entalpia de fusão $(\Delta \mathrm{H})$ para as soluções de gelatina em várias concentrações passando por uma isoterma $5^{\circ} \mathrm{C}$ durante 60 minutos.

Figura 33: Entalpia de fusão $(\Delta \mathrm{H})$ para as soluções de gelatina em várias concentrações submetidas à uma isoterma à $5^{\circ} \mathrm{C}$ por 90 minutos. 90 Figura 34: Valores de $\Delta \mathrm{H}$ em função da duração da isoterma à $5^{\circ} \mathrm{C}$ para a amostra com $6 \mathrm{~g}$ de gelatina/100g de solução.

Figura 35: Entalpia de fusão $(\Delta \mathrm{H})$ para as soluções de gelatina com $6 \mathrm{~g}$ de gelatina/100g de solução passando por uma isoterma à $5^{\circ} \mathrm{C}$ por 240 minutos 
Figura 36: Entalpia de fusão $(\Delta \mathrm{H})$ para as soluções de gelatina com $6 \mathrm{~g}$ de gelatina $/ 100 \mathrm{~g}$ de solução sem extrato avaliadas pelo tempo de isotermas diferentes.

Figura 37: Resposta para módulo de armazenamento - $\mathrm{G}^{\prime}(\mathrm{Pa})$ para a formulação de colágeno em diferentes "gap".

Figura 38: Resposta para módulo de perda - G”(Pa) para a formulação de colágeno em diferentes "gap".

Figura 39: Exemplos de filmes de gelatina adicionado de extrato de boldo-do-Chile........ 96

Figura 40: Imagens dos filmes de colágeno produzidos na concentração de 6\% (w/w)... 107 Figura 41: Exemplos de termogramas para os filmes de gelatina e colágeno adicionados de diferentes concentrações de extrato de boldo Controle; $50 \mathrm{~g}$ de extrato de boldo/100g de macromoléculas; _ـ $150 \mathrm{~g}$ de extrato de boldo/100g de macromoléculas

Figura 42: Exemplos de difratogramas para os filmes de gelatina e colágeno adicionados de $50 \mathrm{~g}$ de extrato de boldo-do-Chile/100g de macromoléculas

Figura 43: Espectros obtidos para os filmes de gelatina produzidos com diferentes concentrações de extrato de boldo

Figura 44: Espectros obtidos para os filmes de colágeno produzidos com diferentes concentrações de extrato de boldo.

Figura 45: Permeabilidade ao vapor de água (PVA) para os filmes de gelatina e colágeno adicionados de extrato de boldo-do-Chile em diferentes concentrações 126

Figura 46: Micrografias de filmes de gelatina da superfície de secagem (a), (b), (c), em contato com a placa (d), (e), (f) e criofraturada (g), (h), (i) (aumento de 1,0k)

Figura 47: Micrografias dos filmes de colágeno da superfície de secagem (a), (b), (c), em contato com a placa (d), (e), (f) e criofraturada (g), (h), (i) (aumento de 1,0k)

Figura 48: Exemplos de imagens capturadas na determinação do ângulo de contato para filmes de colágeno das superfícies em contato com ar (a, b, c) e em contato com a placa (d, e, f).

Figura 49: Exemplos de imagens capturadas na determinação do ângulo de contato para filmes de gelatina das superfícies em contato com ar (a, b, c) e em contato com a placa (d, e, f).

Figura 50: Propriedades de barreira UV/Visível dos filmes de gelatina (G) e colágeno (C) produzidos com diferentes concentrações de extrato de boldo

Figura 51: Resposta para a inibição do reagente ABTS em relação à concentração de extrato de boldo-do-Chile adicionado aos filmes de $\bigcirc$ gelatina e $\bigcirc$ colágeno 


\section{LISTA DE TABELAS}

Tabela 1: Estrutura das aporfinas encontradas nas folhas do boldo-do-Chile. 28

Tabela 2: Estrutura das benzilisoquinolinas encontradas nas folhas de boldo-do-Chile..... 28

Tabela 3: Gradiente linear empregado nas análises UHPLC-DAD-MS $®$ dos extratos de boldo

Tabela 4: Teor de aminoácidos da gelatina e do colágeno utilizados como macromoléculas neste estudo

Tabela 5: Efeito da temperatura de extração sobre o teor de sólidos solúveis ( ${ }^{\circ}$ Brix) e o pH do extrato de boldo-do-Chile (Peumus boldus).

Tabela 6: Efeito da temperatura de extração sobre os parâmetros de cor ( $L^{*}, a^{*}$ e b*) do extrato de boldo-do-Chile (Peumus boldus).

Tabela 7: Resultados obtidos para a avaliação do potencial antioxidante dos extratos de boldo-do-Chile produzidos em diferentes temperaturas.

Tabela 8: Alcaloides e flavonoides identificados à partir da análise UHPLC-DAD-MS realizada em modo electrospray positivo do extrato aquoso do boldo produzido à $30^{\circ} \mathrm{C} .68$ Tabela 9: Flavonoides identificados à partir da análise UHPLC-DAD-MS estabelecidas em modo electrospray em modo negativo do extrato aquoso de boldo produzido à $30^{\circ} \mathrm{C} \ldots \ldots . .70$

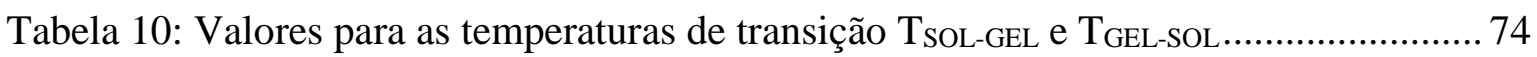
Tabela 11: Histerese $(\Delta \mathrm{T})$ da temperatura das soluções ( $\mathrm{T}_{\text {SOL-GEL }}$ e $\mathrm{T}_{\mathrm{GEL}-\mathrm{SOL}}$ ) de gelatina em diferentes concentrações de macromoléculas e extrato de boldo-do-Chile. .75 Tabela 12: Resultados obtidos para a viscosidade das soluções filmogênicas em diferentes concentrações

Tabela 13: Temperatura de fusão dos géis de gelatina determinada nos ensaios de $\mu$ DSC realizados segundo a metodologia descrita

Tabela 14: Espessura dos filmes de gelatina adicionados de extrato de boldo em diferentes concentrações de macromolécula e extrato de boldo-do-Chile

Tabela 15: Valores de umidade e solubilidade dos filmes de gelatina adicionados de extrato de boldo-do-Chile em diferentes concentrações de macromolécula e extrato. .98 Tabela 16: Valores da tensão na ruptura (TR), elongação na ruptura (ER) e módulo de elasticidade (ME) dos filmes de gelatina adicionados de extrato de boldo em diferentes concentrações de macromolécula e extrato. 
Tabela 17: Valores da força na perfuração (FP), deformação na perfuração (DP) dos filmes de gelatina adicionados de extrato de boldo em diferentes concentrações de macromolécula e extrato.

Tabela 18: Resultados dos parâmetros $\mathrm{L}^{*}, \mathrm{a}^{*} \mathrm{e} \mathrm{b}^{*}$ de filmes produzidos em diferentes concentrações de gelatina e extratos de boldo-do-Chile

Tabela 19: Valores de diferença total de cor $\left(\Delta \mathrm{E}^{*}\right)$ e opacidade para os filmes produzidos em diferentes concentrações de gelatina e extrato de boldo-do-Chile. 105

Tabela 20: Espessura dos filmes de gelatina adicionados de extrato de boldo em diferentes concentrações de macromolécula e extrato de boldo-do-Chile 108 Tabela 21: Valores para umidade e solubilidade para os filmes de colágeno adicionados de extrato de boldo em diferentes concentrações de macromolécula e extrato. 109

Tabela 22: Valores da tensão na ruptura (TR), elongação na ruptura (ER) e módulo de elasticidade (ME) dos filmes de colágeno adicionados de extrato de boldo em diferentes concentrações de macromolécula e extrato.

Tabela 23: Valores da força na perfuração (FP), deformação na perfuração (DP) dos filmes de colágeno adicionados de extrato de boldo em diferentes concentrações de macromolécula e extrato.

Tabela 24: Resultados obtidos dos parâmetros $\mathrm{L}^{*}, \mathrm{a}^{*} \mathrm{e} \mathrm{b}^{*}$ de filmes produzidos em diferentes concentrações de colágeno e extratos de boldo-do-Chile.....

Tabela 25: Valores de diferença total de $\operatorname{cor}\left(\Delta \mathrm{E}^{*}\right)$ e opacidade para os filmes produzidos em diferentes concentrações de colágeno e extrato de boldo-do-Chile. 116

Tabela 26: Resultados dos parâmetros obtidos para as análises térmicas dos filmes de gelatina e colágeno adicionados de extrato de boldo-do-Chile em diferentes concentrações

Tabela 27: Brilho dos filmes de gelatina e colágeno da superfície em contato com o ar de secagem

Tabela 28: Resultados do ângulo de contato dos filmes de gelatina e colágeno da superfície em contato com o ar de secagem 


\section{SUMÁRIO}

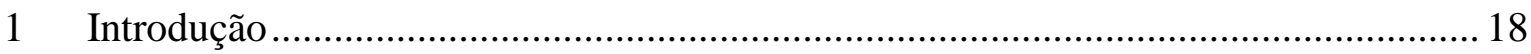

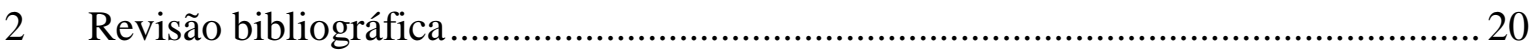

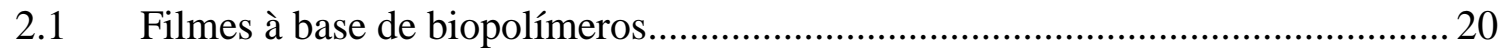

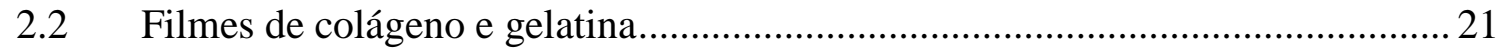

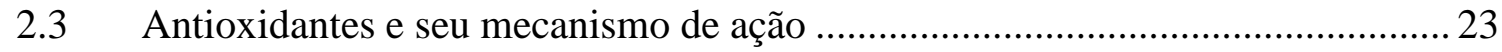

2.4 Características gerais de antioxidantes naturais e particularidades do boldo-do

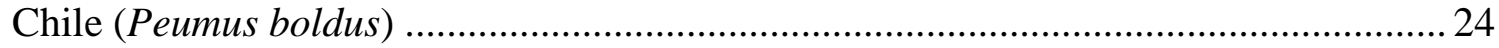

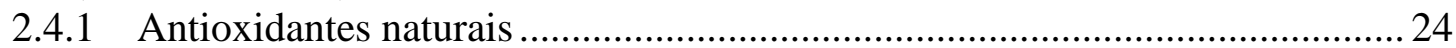

2.4.2 Boldo-do-Chile (Peumus boldus) ................................................................. 27

2.5 Filmes ativos com adição de extratos de planta ................................................ 30

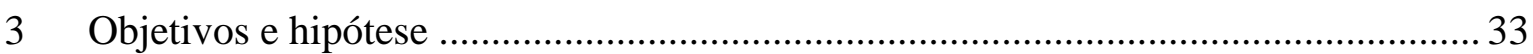

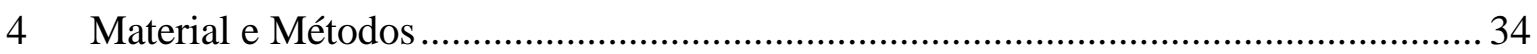

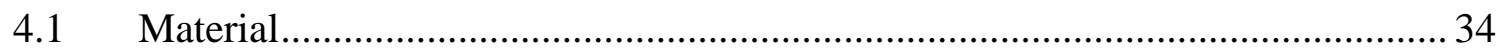

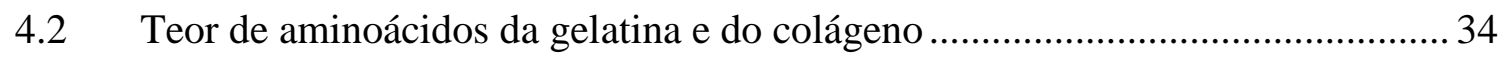

4.3 Preparo do extrato aquoso de boldo-do-Chile ................................................... 34

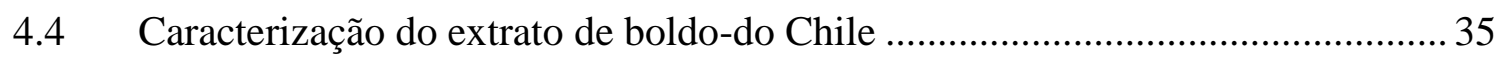

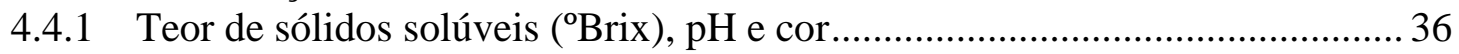

4.4.2 Fenólicos totais (Método de Folin-Ciocalteau) ................................................. 36

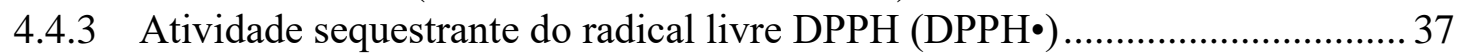

4.4.4 Atividade antioxidante pelo método ABTS $\left(\mathrm{ABTS}^{+\bullet}\right)$...................................... 38

4.4.5 Análise microbiológica: Teste de Sensibilidade pelo Método de Poço Difusão.

4.4.6 Identificação dos compostos por UHPLC-DAD-MS ...................................... 41

4.5 Elaboração das soluções filmogênicas .............................................................. 42

4.6 Caracterização das soluções filmogênicas de gelatina ...................................... 43

4.6.1 Propriedades reológicas das soluções de gelatina ....................................... 43

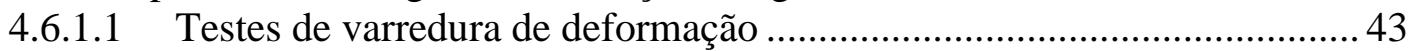

4.6.1.2 Testes de varredura de temperatura ...................................................... 44

4.6.1.3 Testes de varredura de frequência ............................................................ 44

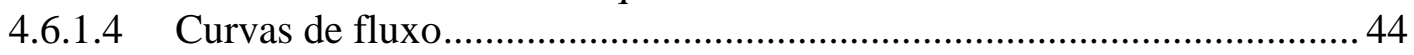

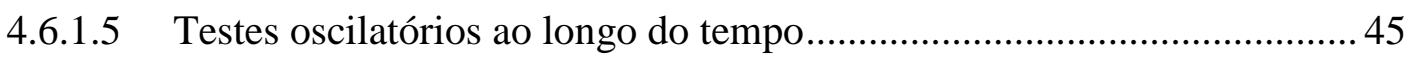

4.6.2 Análises térmicas das soluções filmogênicas de gelatina................................ 45

4.7 Caracterização das soluções filmogênicas de colágeno ………............................. 46

4.8 Preparo e caracterização dos filmes...................................................................... 47

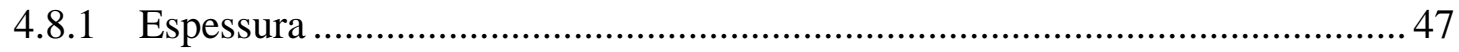

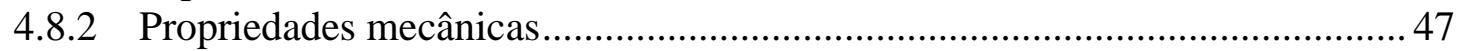

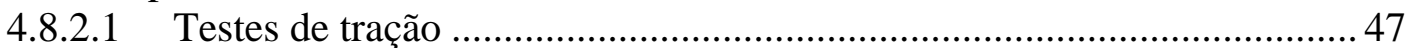

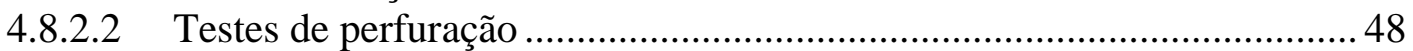

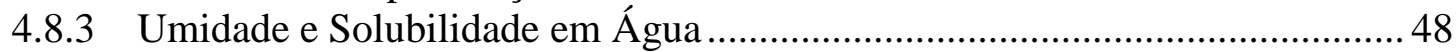




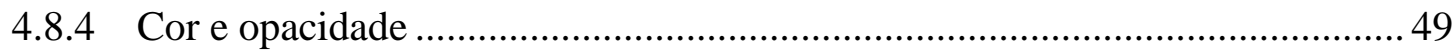

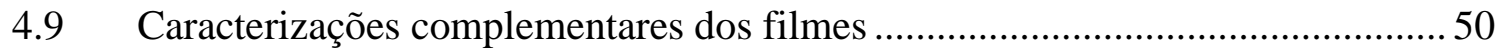

4.9.1 Análises térmicas por calorimetria diferencial de varredura ..........................50

4.9.2 Análises de cristalinidade por difratometria de raio X ................................. 51

4.9.3 Espectroscopia de infravermelho com transformada de Fourier (FTIR)......... 51

4.9.4 Permeabilidade ao vapor de água (PVA) ..................................................... 51

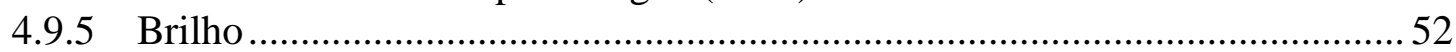

4.9.6 Determinação do ângulo de contato .......................................................... 53

4.9.7 Microscopia eletrônica de varredura (MEV) …….......................................... 54

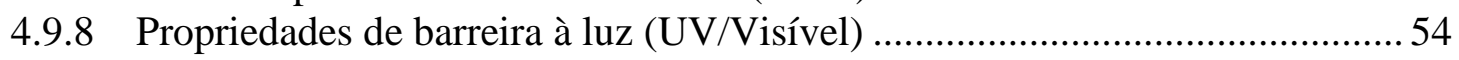

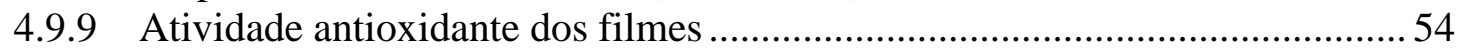

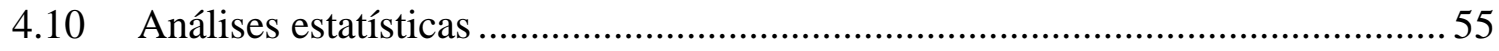

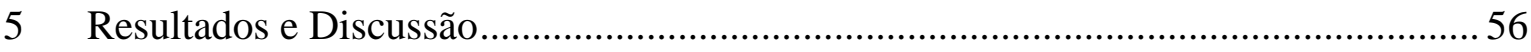

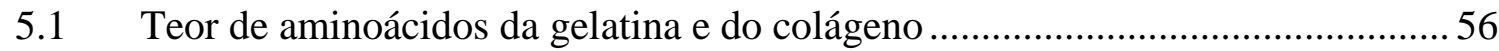

5.2 Caracterizações dos extratos de boldo-do-Chile ................................................58

5.2.1 Teor de sólidos solúveis ( ${ }^{\circ}$ Brix $), \mathrm{pH}$ e cor..........................................................5 58

5.2.2 Avaliação do potencial antioxidante (fenólicos totais, DPPH e ABTS) ......... 60

5.2.3 Análise microbiológica: Teste de Sensibilidade pelo Método de Poço Difusão.

5.2.4 Identificação dos compostos fenólicos por UHPLC-DAD-MS

5.3 Caracterização das soluções filmogênicas de gelatina ........................................... 71

5.3.1 Propriedades reológicas das soluções de gelatina ........................................ 71

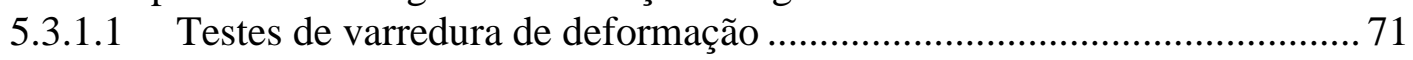

5.3.1.2 Testes de varredura de temperatura .................................................... 72

5.3.1.3 Testes de varredura de frequência .......................................................... 76

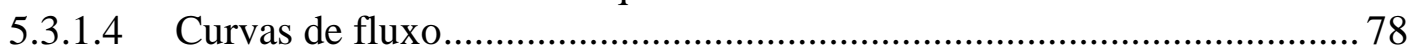

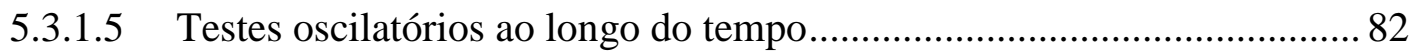

5.3.2 Análises térmicas das soluções de gelatina .................................................... 83

5.4 Caracterização das soluções filmogênicas de colágeno ....................................... 94

5.5 Estudo das propriedades dos filmes de gelatina aditivados com extrato de boldodo-Chile 96

5.5.1 Avaliação do efeito das concentrações do extrato de boldo-do-Chile e de gelatina nas propriedades mecânicas, solubilidade em água e propriedades óticas dos

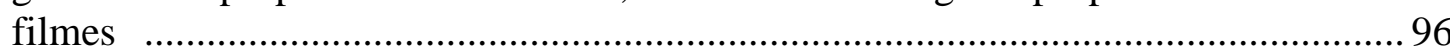

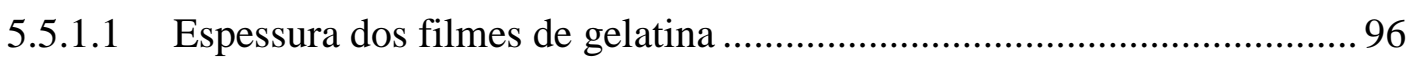

5.5.1.2 Umidade e Solubilidade em água dos filmes de gelatina ....................... 97

5.5.1.3 Propriedades mecânicas por testes de tração ........................................... 99

5.5.1.4 Propriedades mecânicas por testes de perfuração.................................. 102

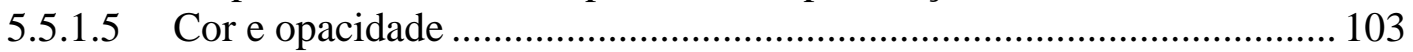

5.6 Estudo das propriedades dos filmes de colágeno aditivados com extrato de boldo-do-Chile

5.6.1 Avaliação do efeito das concentrações do extrato de boldo-do-Chile e de colágeno nas propriedades mecânicas, solubilidade e propriedades óticas dos filmes ...

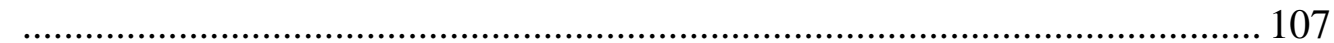

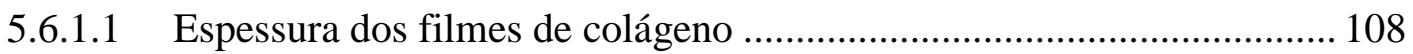

5.6.1.2 Umidade e solubilidade dos filmes de colágeno ................................. 108 
5.6.1.3 Propriedades mecânicas por testes de tração de filmes de colágeno ..... 109

5.6.1.4 Propriedades mecânicas por testes de perfuração de filmes de colágeno....

\subsubsection{Cor e opacidade}

5.7 Propriedades de filmes de gelatina e colágeno produzidos com $6 \mathrm{~g}$ de macromoléculas/100g de SF aditivados com extrato de boldo-do-Chile.....

5.8 Caracterizações complementares dos filmes ................................................ 118

5.8.1 Análises térmicas por calorimetria diferencial de varredura ......................... 118

5.8.2 Análises de cristalinidade por difratometria de raio X ............................... 122

5.8.3 Espectroscopia de infravermelho com transformada de Fourier (FTIR)...... 123

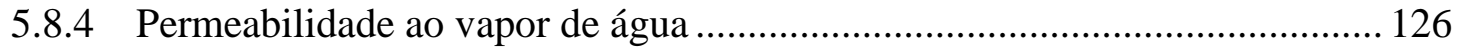

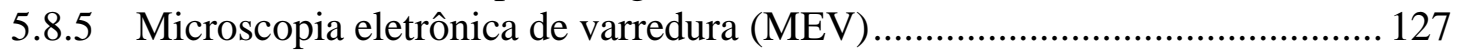

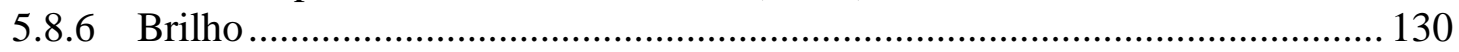

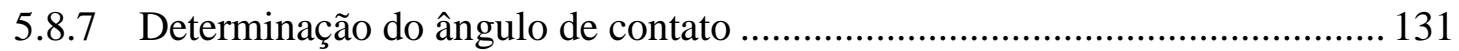

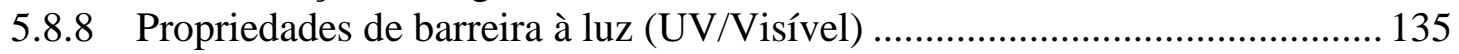

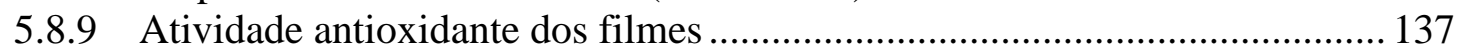

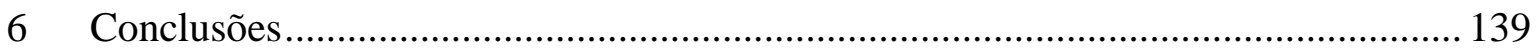

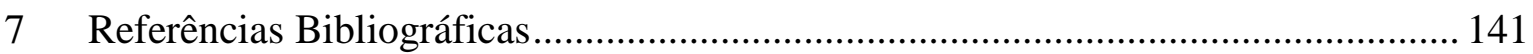




\section{Introdução}

A busca por materiais de embalagem biodegradáveis produzidos à partir de fontes renováveis, visando a redução de problemas ambientais, têm aumentado a cada dia. Sabese que os filmes à base de biopolímeros podem ser considerados uma alternativa aos materiais sintéticos (KROCHTA, 2002; TORRES, 1994). Aliado à isso, nos últimos anos, tem havido uma demanda por embalagens que ofereçam melhorias sobre a vida útil de alimentos, sendo que, o principal fator apontado como causador da perda de qualidade é a oxidação (HONG; KROCHTA, 2006; LI et al., 2014).

A oxidação se dá, basicamente, pela ação dos radicais livres que reagem com os lipídeos presentes nos alimentos. Para diminuir a ação desses radicais livres podem-se utilizar agentes antioxidantes (CHEN et al., 2012; DEL RÉ; JORGE, 2012). Os antioxidantes são substâncias que podem prevenir a ação desses radicais impedindo a oxidação de alimentos que podem acarretar no desenvolvimento de sabores estranhos, alterações de cor e sabor e perdas nutricionais (MARCOS et al., 2014).

Atualmente, as pesquisas se concentram em embalagens biodegradáveis de alimentos com agentes antioxidantes de fontes naturais, como extratos de plantas. Isso porque o uso de antioxidantes sintéticos, como o BHA (butil-hidroxi-anisol) ou BHT (butil-hidroxi-tolueno), tem sido questionado, sobretudo em relação à sua inocuidade (DEL RÉ; JORGE, 2012; LI et al., 2014; MARCOS et al., 2014).

Assim, os agentes antioxidantes oriundos de fontes naturais, como extratos de plantas, surgem como uma possível alternativa à substituição dos agentes sintéticos. E, sua adição em filmes à base de biopolímeros possibilita a produção de embalagens ativas (BITENCOURT et al., 2014).

Vários estudos sobre filmes ativos têm sido realizados com antioxidantes naturais, principalmente compostos fenólicos presentes em extratos aquosos de vegetais, como alternativas aos antioxidantes sintéticos. Assim, Gómez-Guillén et al. (2007) estudaram a adição de extrato aquoso de murta (Ugni molinae Turcz) em filmes de gelatina de peixe, e Gómez-Estaca et al. (2007) aditivaram filmes de gelatina com extratos aquosos de orégano e alecrim. Moradi et al. (2012) e Cerqueira et al. (2010) produziram filmes ativos a base de quitosana aditivado com extrato de semente de uva, e filmes de galactomanana com extrato de semente de acácia, respectivamente. Norajit, Kim e Ryu (2010) desenvolveram filmes ativos a base de alginato contendo extrato aquoso de ginseng. 
Extrato aquoso de chá verde foi adicionado em filmes de isolado proteico de soja (THEIVENDRAN, HETTIARACHCHY; JONHSON, 2006), filmes de quitosana (SIRIPATRAWAN; HARTE, 2010), filmes a base de blendas de ágar e gelatina (GIMÉNEZ et al., 2013) e filmes à base de gelatina de peixe (LI et al., 2014). Li et al. (2014) estudaram a adição de outros extratos em filmes de gelatina de peixe, como o extrato de semente de uva e o extrato de gengibre. Bitencourt et al. (2014) estudaram a produção de filmes ativos de gelatina adicionados de extrato de cúrcuma. Todos esses autores consideraram que produziram filmes com atividades antioxidantes.

Um vegetal ainda não empregado em estudos sobre filmes com atividade antioxidante é o boldo-do-Chile: Peumus boldus, que é uma planta nativa do Chile, pertencente à família Monimiaceae. Normalmente, infusões de folhas desta erva são recomendados para o tratamento de problemas digestivos e hepáticos (RUIZ et al., 2008). $\mathrm{Na}$ literatura, é possível encontrar muitas informações relacionadas às propriedades antioxidantes do extrato de boldo-do-Chile e sobre o alto teor de substâncias fenólicas (FALÉ et al., 2012; MATSUBARA; RODRIGUEZ-AMAYA, 2006; MORAIS et al., 2009; O'BRIEN; CARRASCO-POZO; SPEISKY, 2006; RUIZ et al., 2008; UQUICHE et al., 2012), podendo ser, portanto, uma boa fonte de antioxidantes naturais a ser aplicada em filmes proteicos (gelatina ou colágeno).

Além da adição do extrato de boldo-do-Chile conferir propriedades antioxidantes a estes filmes, espera-se que, devido à presença de compostos fenólicos, melhore as propriedades físico-químicas destes materiais (BIFANI et al., 2007). De acordo com Wang et al. (2012), a adição de compostos fenólicos em materiais proteicos pode provocar alterações químicas (ex.: reticulação) que implicariam em um rearranjo estrutural das cadeias polipeptídicas. 


\section{Revisão bibliográfica}

\subsection{Filmes à base de biopolímeros}

Os filmes à base de biopolímeros são uma alternativa aos plásticos convencionais, podendo ser produzidos a partir de fontes naturais ou sintéticas. Os biopolímeros naturais são produzidos principalmente a partir de plantas, animais e microrganismos, e ainda, podem ser obtidos a partir de resíduos de processos da indústria alimentícia (STEVENS, 2002; TORRES, 1994).

Os principais biopolímeros, do ponto de vista tecnológico, são proteínas e polissacarídeos. Os polissacarídeos mais empregados na elaboração de filmes são celulose (ARVANITOYANNIS; BILIADERIS, 1999; TOMÉ, 2008), quitosana (KHOSHGOZARAN-ABRAS et al., 2012; SRINIVASA et al., 2004; SRINIVASA; RAMESH; THARANATHAN, 2007) e amido (JANSSON; THUVANDER, 2004; TALJA et al., 2008; YOON, PARK, BYUN, 2012). Os filmes à base de polissacarídeos, normalmente, são transparentes e oferecem moderada barreira contra oxigênio e dióxido de carbono sendo bastante compatíveis com outros materiais, entretanto possuem alta permeabilidade ao vapor de água e alta solubilidade em água, além de baixas propriedades mecânicas (SOUZA; DITCHFIELD; TADINI, 2010).

Por outro lado, as proteínas mais utilizadas em estudos de filmes comestíveis e/ou biodegradáveis são o glúten (LENS et al., 2003; MARCUZZO et al., 2010; SUN; SONG; ZHENG, 2007), as proteínas do soro do leite (GALIETTA et al., 1998; GOUNGA; XU; WANG, 2007; OSÉS et al. 2009), a gelatina (ALVES et al., 2011; SOBRAL et al., 2001; VANIN et al., 2005) e o colágeno (ANGELE et al., 2004; WOLF; SOBRAL; TELIS, 2009; SILVA et al., 2001). Os filmes de proteínas possuem boa barreira ao oxigênio, mas apresentam uma pobre barreira ao vapor de água. Em geral possuem melhores propriedades que os filmes à base de polissacarídeos. Essas características estão intimamente relacionadas aos aminoácidos que compõem as proteínas. Como se tratam de 20 aminoácidos, existe uma grande variação nas propriedades dos filmes, devido às inúmeras combinações estruturais possíveis que as proteínas podem assumir (KROCHTA, 2002; PÉREZ-GAGO, 2011). 


\subsection{Filmes de colágeno e gelatina}

Conforme mencionado anteriormente, o colágeno e a gelatina são proteínas bastante empregadas nos estudos com filmes biodegradáveis e/ou comestíveis. O colágeno é uma proteína complexa e fibrosa presente em todos os tecidos animais. De acordo com Friess (1998), existem 13 tipos de colágeno que diferem entre si pelo arranjo e tamanho das cadeias polipeptídicas, mas o colágeno mais abundante é o de Tipo I, que é predominante em animais de ordem superior (mamíferos), especialmente na pele, tendões e ossos. Ele é constituído por três cadeias polipeptídicas helicoidais unidas por ligações cruzadas intermoleculares. Sua estrutura é caracterizada pela repetição do triplete glicina, prolina e hidroxipolina. (ARVANITOYANNIS, 2002; CONCA, 2002; FRIESS, 1998; GÓMEZ-GUILLÉN et al., 2011; KALMAN, 2004).

A extração de colágeno a partir de couro de bovino origina dois tipos de produtos: fibras de colágeno e pó de colágeno. Ambos podem ser empregados na produção de biomateriais, e, tanto o pó, como a fibra, são insolúveis em água, mas é possível solubilizá-los pela redução do pH do meio (WOLF; SOBRAL; TELIS, 2009).

O colágeno tem sido bastante estudado como biomaterial na área médica devido à sua abundância e biocompatibilidade (ANGELE et al., 2004; CHARULATHA; RAJARAM, 2003; SIONKOWSKA, 2000; SIONKOWSKA et al., 2010), mas existem também trabalhos que utilizam essa macromolécula para elaboração de filmes biodegradáveis e/ou comestíveis (DEIBER; PEIROTTI, OTTONE, 2011; GÓMEZGUILLÉN et al., 2011; GROVER et al., 2012; HE et al., 2011; WOLF; SOBRAL; TELIS, 2009), com principal destaque para invólucros comerciais de salsichas que já são produzidos com colágeno (OSBURN, 2002; THARANATHAN, 2003).

Em geral, os filmes de colágeno apresentam-se como boa barreira ao oxigênio desde que utilizados em baixa umidade relativa (MAIA; PORTE; SOUZA, 2000). Especificamente para uso como embalagens, Wolf, Sobral e Telis (2009) desenvolveram filmes compósitos de colágeno, isto é, colágeno em pó foi solubilizado e colágeno em fibra insolúvel foi usado como carga de reforço.

A gelatina, por sua vez, é obtida por hidrólise parcial do colágeno. Sua estrutura primária é bastante semelhante à do colágeno, com algumas diferenças que podem ser atribuídas aos processos de tratamento e extração. Dentre as diferenças existentes, o processo de extração remove os grupos asparagina e glutamina. De forma geral, a 
composição da gelatina varia de acordo com a origem do colágeno da qual ela foi extraída, bem como do método de extração (ARVANITOYANNIS, 2002).

Basicamente, existem dois tipos de gelatina em função do tipo de extração: Gelatina Tipo A e Tipo B. Essa diferenciação depende do tratamento que foi dado ao colágeno antes da extração. A gelatina do Tipo A é produzida a partir de hidrólise ácida do colágeno, e os ácidos mais utilizados são o ácido sulfúrico e o ácido clorídrico. Para a produção de gelatina do Tipo B, utiliza-se um tratamento alcalino (EYSTURSKARĐ et al., 2009; KALMAN, 2004; RATANAVARAPORN et al., 2010).

Segundo Eysturskarð et al. (2009), o tratamento influencia diretamente o ponto isoelétrico $(\mathrm{pI})$ da gelatina. $\mathrm{O}$ pI da gelatina produzida por via alcalina (gelatina tipo B) fica entre 4,8-5,2, que é inferior ao ponto isoelétrico da gelatina produzida por via ácida, que se situa entre 8-9. Na tecnologia de filmes, a gelatina mais utilizada é a de tipo A.

A gelatina tem excelentes propriedades filmogênicas, e é produzida em muitos países, com baixo custo. Em sua composição, encontram-se frações de glicina (cerca de $33 \%$ ), prolina e hidroxiprolina (22\%), o restante, 45\%, é constituído por 17 aminoácidos, sendo que desta fração, a alanina é o mais abundante (ARVANITOYANNIS, 2002; KALMAN, 2004; SOBRAL et al., 2001). Diferentemente do colágeno, a gelatina pode ser solubilizada em água acima de $45^{\circ} \mathrm{C}$, sendo, portanto, uma das raras proteínas consideradas como hidrocoloides.

Os filmes de gelatina são, em geral, transparentes, homogêneos, flexíveis e de fácil manipulação, além disso, eles possuem alta permeabilidade ao vapor de água e são bastante sensíveis a umidade relativa (SOBRAL et al., 2001; ARVANITOYANNIS, 2002). Existem muitos trabalhos sobre filmes de gelatina, pura ou em blendas com outros biopolímeros, inclusive sobre a produção de capsulas para medicamentos (BUSSEMER; DASHEVSKY; BODMEIER, 2003; DONG; WANG; DU, 2006).

$\mathrm{Na}$ área de coberturas e filmes biodegradáveis e/ou comestíveis existem muitos trabalhos que avaliam as propriedades desses materiais produzidos a partir dessa macromolécula com diferentes tipos de plastificantes, aditivos e também com modificações químicas, visando melhoria das propriedades físicas dos filmes (ALVES et al., 2011; BIGI et al., 2001; BERGO; MORAES; SOBRAL, 2013; BERGO; SOBRAL, 2007; CARVALHO; GROSSO, 2004; 2006; GÓMEZ-GUILLÉN et al., 2007; SOBRAL et al., 2001; SPANNEBERG et al., 2012; VANIN et al., 2005). 


\subsection{Antioxidantes e seu mecanismo de ação}

Os antioxidantes podem fazer parte da composição dos alimentos, mas, normalmente são adicionados aos produtos durante o processamento, sendo que seu papel é, basicamente, evitar a oxidação dos alimentos, mantendo a qualidade dos alimentos, prolongando a vida-de-prateleira (GERMAN, 2002; REISCHE; LILLARD; EITENMILLER, 2008).

Segundo Reische, Lillard e Eitenmiller (2008), os antioxidantes podem ser classificados pelo mecanismo de ação em antioxidantes primários e secundários. Sendo que algumas substâncias podem apresentar mais do que um mecanismo de atuação, e nesse caso, esses compostos são conhecidos como antioxidantes de função múltipla.

Os antioxidantes primários são também conhecidos como antioxidantes do tipo I ou antioxidantes de quebra de cadeia. Devido à natureza química destas moléculas, elas podem atuar como receptores livres/removedores (scavengers) de radicais, atrasando ou inibindo a etapa de iniciação, ou ainda, interrompendo a propagação de autoxidação. $\mathrm{O}$ mecanismo de ação dos antioxidantes preventivos é impedir a formação de espécies reativas de oxigênio (ROS) ou de espécies removedoras (scavenge species) responsáveis pela iniciação da oxidação. Os antioxidantes de quebra de cadeia atuam interceptando radicais propagadores de oxidação. De fato, existem substâncias que são capazes de atuar de ambas as maneiras para impedir a oxidação lipídica (KALOGEROPOULOS; CHIOU, 2009; WANASUNDARA; SHAHIDI, 2005). Os exemplos mais comuns de antioxidantes primários são o butil-hidroxi-anisol (BHA), butil-hidroxi-tolueno (BHT), terc-butilhidroquinona (TBHQ) e propil galato (PG), que são sintéticos, e os tocoferóis, que são naturais (RAMALHO; JORGE, 2006; REISCHE; LILLARD; EITENMILLER, 2008).

Os antioxidantes secundários, ou tipo 2, atuam diminuindo a taxa de oxidação por várias ações diferentes. No entanto, eles não convertem radicais livres em produtos mais estáveis (WANASUNDARA; SHAHIDI, 2005). Existe uma subclassificação dos antioxidantes secundários, baseada em sua maneira de atuação. São eles:

- Sinergistas, que são substâncias com pouca ou nenhuma atividade antioxidante, que atuam aumentando a atividade dos antioxidantes primários, quando utilizados em combinação. Exemplos: ácido cítrico e ácido tartárico (REISCHE; LILLARD; EITENMILLER, 2008); 
- Removedores de oxigênio são compostos que atuam capturando o oxigênio presente no meio, formando compostos estáveis, tornando-o, desta forma, indisponível para atuarem como propagadores da autoxidação. Exemplos: ácido ascórbico, ascorbatos, sulfito e eritorbatos (RAMALHO; JORGE, 2006);

- Antioxidantes biológicos incluem várias enzimas, como glucose oxidade, superóxido dismurtase e catalases. Estas substâncias podem remover oxigênio ou compostos altamente reativos de um sistema alimentício (WANASUNDARA; SHAHIDI, 2005);

- Agentes quelantes complexam íons metálicos, principalmente cobre e ferro, que catalisam a oxidação lipídica. Os exemplos mais comuns são ácido cítrico e seus sais, fosfatos e sais de ácido etileno diamino tetra acético (EDTA) (HALLIWELL， 2001; RAMALHO; JORGE， 2006; WANASUNDARA; SHAHIDI, 2005);

- Antioxidantes mistos incluem compostos presentes em plantas e animais, sendo esses, proteínas hidrolisadas, flavonoides e derivados de ácido cinâmico, dentre outros (RAMALHO; JORGE, 2006).

\subsection{Características gerais de antioxidantes naturais e particularidades do boldo-do Chile (Peumus boldus)}

\subsubsection{Antioxidantes naturais}

O emprego de antioxidantes sintéticos tem sido bastante questionado com relação a inocuidade, uma vez que existem trabalhos que demonstram a toxidez dessas substâncias. Com isso, as pesquisas concentram-se em compostos naturais que possuem essa funcionalidade (DEL RÉ; JORGE, 2012; SHAHIDI; ZHONG, 2005). Aliado à isso, surge o apelo para a diminuição do consumo de produtos alimentos industrializados, cuja produção reconhecidamente envolva o emprego de substanciais quantidades de aditivos sintéticos (VALENTÃO et al., 2002).

Os antioxidantes naturais são constituídos por compostos fenólicos, vitaminas e enzimas. Essas substâncias são capazes de atuar na autoxidação e prevenção da 
rancificação. Os compostos antioxidantes provenientes de plantas não possuem uma maneira de atuação antioxidante exclusiva, sendo considerados antioxidantes mistos (RAMALHO; JORGE, 2006; OLIVEIRA et al., 2009; SHAHIDI, 1997; SHAHIDI; ZHONG, 2005).

Os compostos fenólicos das plantas, quando vivas, protegem as plantas contra oxidação por injúria nos tecidos. Esses compostos se oxidam e combinam com proteínas e outros compostos. Além disso, os compostos fenólicos protegem as plantas contra os herbívoros, pois conferem um sabor amargo (MUKHOPADHYAY, 2000; SHAHIDI, 1997).

De acordo com Macheix, Fleuriet e Sarni-Manchado (2006), vários compostos fenólicos (Figura 1) foram identificados no reino vegetal, e todos eles têm em comum a presença de um ou vários ciclos benzênicos ligados à hidroxila, sendo que esses grupos funcionais conferem o poder antioxidante à essas substâncias. Esses compostos fenólicos se diferenciam pela estrutura da cadeia carbônica de base (cadeias simples ou polimerizadas), e também pelo grau de modificação (grau de oxidação, hidroxilação e metilação), ou ainda pelas ligações com outras moléculas (glucídeos, lipídeos e proteínas).

Figura 1: Esquema de classificação dos compostos fenólicos

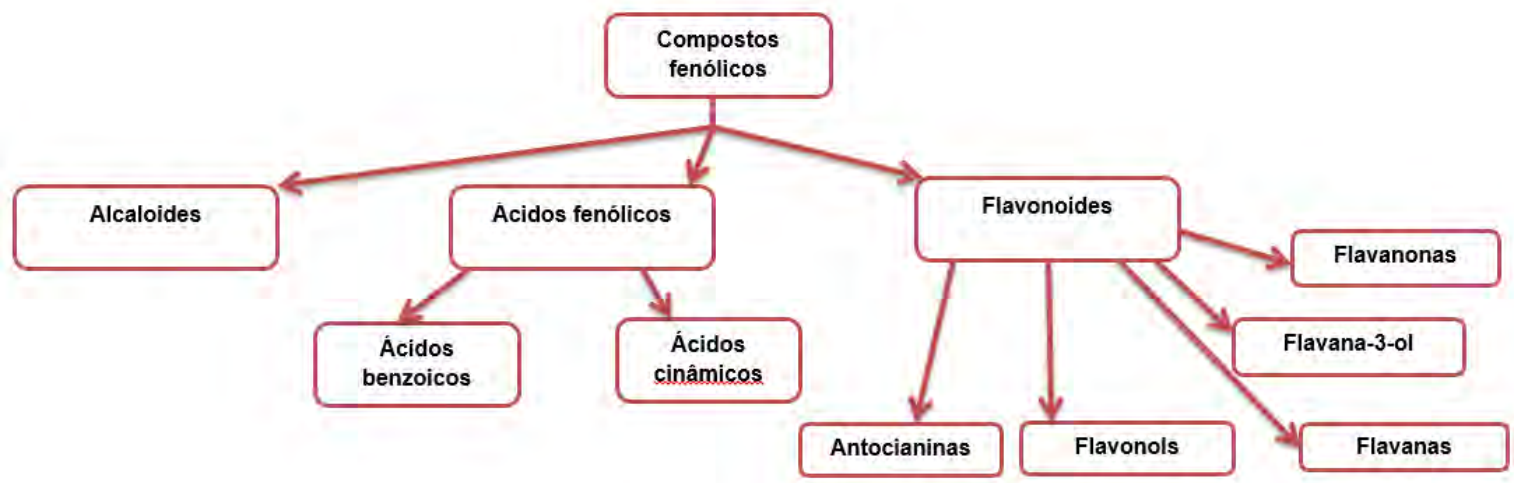

Fonte: COLLIN, S. et al. Chapitre 1 : Nomenclature et voies de synthèses des principaux polyphénols. In: COLLIN, S.; CROUZET, J. Polyphénols et procédés. Lavoisier, p. 5-27, 2011.

No grande grupo dos compostos fenólicos, os flavonoides e os ácidos fenólicos são os que mais se destacam e, são considerados os antioxidantes mais comuns de fontes naturais (BROINIZI et al., 2007). Quimicamente, eles possuem um anel aromático com 
uma ou mais hidroxilas, podendo apresentar outros grupos substituintes em sua estrutura, como ésteres, metil-ésteres e glicosídios (DEL RÉ; JORGE, 2012).

Os flavonoides são produtos secundários do metabolismo das plantas. Nesse grupo encontram-se as antocianinas, catequinas, flavonas, flavonóis, isoflavonas e proantocianidinas, todos antioxidantes e que tem como principal característica de atuação a capacidade de se complexar com íons metálicos. No entanto, observa-se que, os flavonoides também podem atuar como antioxidantes primários e removedores de ânions superóxido. São comumente encontrados em especiarias e ervas para chás em geral (MUKHOPADHYAY, 2000; NAKATANI, 1997; REISCHE; LILLARD; EITENMILLER, 2008; SHAHIDI, 1997).

Assim como os flavonoides, os ácidos fenólicos, como ácido caféico, p-cumárico, ferúlico, gálico, hidroxibenzóico, etc, essas substâncias também reagem com íons metálicos. As flavonas (ex: luteolina, diosmetina e nobiletina) e flavonóis (ex: kaempferol, miricetina e quercetina) são bastante comuns em frutas na forma de glicosídeos, mas também é possível encontra-los em ervas para chás e no vinho. Destes compostos, a quercetina merece destaque como um potente antioxidante (MUKHOPADHYAY， 2000; NAKATANI, 1997; REISCHE; LILLARD; EITENMILLER, 2008; SHAHIDI, 1997).

Segundo Troncoso et al. (2005), existem alguns fatores que podem influenciar na presença desses compostos nas plantas, como origem, espécie, fase de desenvolvimento durante a colheita, estímulos proporcionados pelo meio (fatores climáticos, exposição a microrganismos e insetos).

De acordo com Del Ré e Jorge (2012), algumas especiarias, como manjericão, orégano, sálvia e alecrim, possuem um elevado teor de compostos fenólicos, flavonoides e terpenoides. Morais et al. (2009) confirmaram a presença de compostos fenólicos antioxidantes no chá verde (Camelia sinensis), na canela (Cinnamonum zeylanicum), no cravo (Eugenia aromatica), e em folhas de louro (Laurus nobilis). Matsubara e Rodriguez-Amaya (2006) encontraram teores de importantes antioxidantes, como a quercetina e kaempferol em chá de boldo-do-Chile (Peumus boldus M.), chá de camomila (Matricaria chamomilla L.), chá preto (Camellia sinensis) e chá de erva doce (Pimpinella anisum L.). 


\subsubsection{Boldo-do-Chile (Peumus boldus)}

O boldo-do-Chile (Peumus boldus) é uma planta rasteira e endêmica do Chile que é frequentemente utilizada no preparo de infusões (DEL VALLE et al., 2004; DEL VALLE et al., 2005; UQUICHE et al., 2012; SOTO et al., 2014). O chá de boldo é utilizado como estimulante digestivo, diurético, relaxante e em tratamentos de distúrbios hepáticos e da vesícula biliar (FALÉ et al. 2012; SOTO et al., 2014).

As folhas de boldo possuem mais de 30 compostos, como quercetina, glicosídeos, kaempferol, fenólicos, proantocianinas, que possuem efeito antioxidante e quimiopreventivo (SOTO et al., 2014). Além disso, existem teores consideráveis de taninos, óleos essenciais (ascaridol e cineol), flavonoides (catequinas) e alcaloides (boldina), a esses compostos também é atribuída à atividade antioxidante do boldo-doChile (O'BRIEN; CARRASCO-POZO; SPEISKY, 2006; QUEZADA et al., 2004; SCHMEDA-HIRSCHMANN et al., 2003).

Os alcaloides, substâncias que também possuem atividade antioxidante reconhecida, podem ser encontrados em folhas de boldo (Peumus boldus Mol.), sendo que os mais frequentes são as aporfinas (Tabela 1) e as benzilisoquinolinas (Tabela 2) (O'BRIEN; CARRASCO-POZO; SPEISKY, 2006). Dentre as aporfinas, a boldina [(S)2,9-Dihydroxy-1,10-dimethoxy-aporphine] é a mais abundante (O'BRIEN; CARRASCO-POZO; SPEISKY, 2006). Existem outras substâncias dessa mesma família que podem ser igualmente encontradas nas folhas do boldo. 
Tabela 1: Estrutura das aporfinas encontradas nas folhas do boldo-do-Chile.

\begin{tabular}{lcclcccc}
\hline Nome & $\mathbf{1}$ & $\mathbf{2}$ & $\mathbf{3}$ & $\mathbf{6}$ & $\mathbf{9}$ & $\mathbf{1 0}$ & $\mathbf{1 1}$ \\
\hline Boldina & $\mathrm{OCH}_{3}$ & $\mathrm{OH}$ & $\mathrm{H}$ & $\mathrm{CH}_{3}$ & $\mathrm{OH}$ & $\mathrm{OCH}_{3}$ & $\mathrm{H}$ \\
Glaucina & $\mathrm{OCH}_{3}$ & $\mathrm{OCH}_{3}$ & $\mathrm{H}$ & $\mathrm{CH}_{3}$ & $\mathrm{OCH}_{3}$ & $\mathrm{OCH}_{3}$ & $\mathrm{H}$ \\
Isoboldina & $\mathrm{OH}$ & $\mathrm{OCH}_{3}$ & $\mathrm{H}$ & $\mathrm{CH}_{3}$ & $\mathrm{OH}$ & $\mathrm{OCH}_{3}$ & $\mathrm{H}$ \\
Bulbocapnina & $-\mathrm{O}-\mathrm{CH}_{2}-\mathrm{O}-$ & $\mathrm{H}$ & $\mathrm{CH}_{3}$ & $\mathrm{H}$ & $\mathrm{OCH}_{3}$ & $\mathrm{OH}$ \\
Anonaina & $-\mathrm{O}-\mathrm{CH}_{2}-\mathrm{O}-$ & $\mathrm{H}$ & $\mathrm{H}$ & $\mathrm{H}$ & $\mathrm{H}$ & $\mathrm{H}$ \\
Apomorfina & $\mathrm{H}$ & $\mathrm{H}$ & $\mathrm{H}$ & $\mathrm{CH}_{3}$ & $\mathrm{H}$ & $\mathrm{OH}$ & $\mathrm{OH}$ \\
3-Bromo-boldina & $\mathrm{OCH}_{3}$ & $\mathrm{OH}$ & $\mathrm{Br}$ & $\mathrm{CH}_{3}$ & $\mathrm{OH}$ & $\mathrm{OCH}_{3}$ & $\mathrm{H}$ \\
3-Iodo-boldina & $\mathrm{OCH}_{3}$ & $\mathrm{OH}$ & $\mathrm{I}$ & $\mathrm{CH}_{3}$ & $\mathrm{OH}$ & $\mathrm{OCH}_{3}$ & $\mathrm{H}$ \\
N-metilglaucina & $\mathrm{OCH}_{3}$ & $\mathrm{OCH}$ & $\mathrm{H}$ & $\left(\mathrm{CH}_{3}\right)_{2}$ & $\mathrm{OCH}_{3}$ & $\mathrm{OCH}_{3}$ & $\mathrm{H}$ \\
N-metilboldina & $\mathrm{OCH}_{3}$ & $\mathrm{OH}$ & $\mathrm{H}$ & $\left(\mathrm{CH}_{3}\right)_{2}$ & $\mathrm{OH}$ & $\mathrm{OCH}_{3}$ & $\mathrm{H}$ \\
N-metilaurotetanina & $\mathrm{OCH}_{3}$ & $\mathrm{OCH}$ & $\mathrm{H}$ & $\mathrm{CH}_{3}$ & $\mathrm{OH}$ & $\mathrm{OCH}_{3}$ & $\mathrm{H}$ \\
Norglaucina & $\mathrm{OCH}_{3}$ & $\mathrm{OCH}_{3}$ & $\mathrm{H}$ & $\mathrm{H}$ & $\mathrm{OCH}_{3}$ & $\mathrm{OCH}_{3}$ & $\mathrm{H}$ \\
\hline
\end{tabular}<smiles>O=[NH+]C1Cc2ccccc2-c2cccc3c2C31</smiles>

Fonte: FALÉ, P.L. et al. Acetylcholinesterase inhibition, antioxidant activity and toxicity of Peumus boldus water extracts on HeLa and Caco-2 cell lines. Food and Chemical Toxicology, v. 50, p. 2656-2662, 2012.; O'BRIEN, P.; CARRASCO-POZO, C.; SPEISKY, H. Boldine and its antioxidant or health-promoting properties. Chemico-Biological Interactions, v. 159, p. 1-17, 2006.

Além das aporfinas, é possível encontrar um outro tipo de alcaloide que são as benzilisoquinolinas (O'BRIEN; CARRASCO-POZO; SPEISKY, 2006), das quais a representamte mais conhecida é a reticulina (O'BRIEN; CARRASCO-POZO; SPEISKY, 2006; SOTO et al., 2014).

Tabela 2: Estrutura das benzilisoquinolinas encontradas nas folhas de boldo-do-Chile.

\begin{tabular}{llllll}
\hline Nome & $\mathbf{2}$ & $\mathbf{4}$ & $\mathbf{5}$ & $\mathbf{6}$ & $\mathbf{7}$ \\
\hline Reticulina & $\mathrm{CH}_{3}$ & $\mathrm{OCH}_{3}$ & $\mathrm{OH}$ & $\mathrm{OCH}_{3}$ & $\mathrm{OH}$ \\
Coclaurina & $\mathrm{H}$ & $\mathrm{OH}$ & $\mathrm{H}$ & $\mathrm{OCH}_{3}$ & $\mathrm{OH}$ \\
Laudanosina & $\mathrm{CH}_{3}$ & $\mathrm{OCH}_{3}$ & $\mathrm{OCH}_{3}$ & $\mathrm{OCH}_{3}$ & $\mathrm{OCH}_{3}$ \\
Laudanosolina & $\mathrm{CH}_{3}$ & $\mathrm{OH}$ & $\mathrm{OH}$ & $\mathrm{OH}$ & $\mathrm{OH}$ \\
N-metilcoclaurina & $\mathrm{CH}_{3}$ & $\mathrm{OH}$ & $\mathrm{H}$ & $\mathrm{OCH}_{3}$ & $\mathrm{OH}$
\end{tabular}<smiles>c1ccc(CC2NCCc3ccccc32)cc1</smiles>

Fonte: FALÉ, P.L. et al. Acetylcholinesterase inhibition, antioxidant activity and toxicity of Peumus boldus water extracts on HeLa and Caco-2 cell lines. Food and Chemical Toxicology, v. 50, p. 2656-2662, 2012.; O'BRIEN, P.; CARRASCO-POZO, C.; SPEISKY, H. Boldine and its antioxidant or health-promoting properties. Chemico-Biological Interactions, v. 159, p. 1-17, 2006.

Ainda de acordo com O’Brien, Carrasco-Pozo e Speisky (2006), em se tratando de infusões (extratos aquosos), são maiores os teores de catequina, ácido gálico e tânico, encontrando-se baixos teores de alcaloide (boldina), sendo que, em extratos etanólicos o comportamento observado é o inverso (FALÉ et al., 2012). 
O mecanismo de ação das substâncias antioxidantes, presentes nas infusões de boldo (extração aquosa em alta temperatura), é característico de um removedor de radicais livres, mas, algumas substâncias presentes, como os flavonoides podem atuar como antioxidantes mistos (RAMALHO; JORGE, 2006; SCHMEDA-HIRSCHMAN et al., 2003).

Muitos fatores podem influenciar o tipo de compostos presentes nas folhas do boldo, bem como os teores encontrados nos diferentes extratos. Segundo Troncoso et al. (2005), fatores ligados a produção da planta, sua colheita e as partes da planta utilizadas podem influenciar no teor e no tipo de compostos extraídos. Além disso, é necessário considerar algumas condições do processo de extração, como a temperatura e o tipo de solvente utilizado. 


\subsection{Filmes ativos com adição de extratos de planta}

Por definição, uma embalagem pode ser considerada como ativa, quando tiver a propriedade de selecionar, liberar progressivamente, absorver ou transformar um composto, ou um gás (GONTARD, 2000). Na maioria dos casos, o desenvolvimento de filmes ativos implica na adição, na formulação do material, de um componente ativo, isto é, com certa atividade (ex.: antioxidante, antimicrobiano, filtro UV, dentre outros) (LÓPEZ-RUBIO et al., 2004).

Os filmes com adição de antioxidantes naturais são vistos hoje, como uma das tecnologias mais interessantes na tecnologia de filmes ativos. Esses filmes podem proteger os alimentos tanto contra danos físicos, como contra danos químicos, além de possibilitar uma redução no teor de conservantes nos alimentos (AKHATAR et al., 2012, 2013).

Existem muitos trabalhos envolvendo filmes à base de biopolímeros adicionados de extratos vegetais. Gómez-Guillén et al. (2007) estudaram a adição de extrato aquoso de murta (Ugni molinae Turcz) em filmes de gelatina de peixe, os autores obtiveram filmes transparentes com discreto decréscimo nas propriedades mecânicas, por outro lado, os filmes apresentaram boas propriedades de barreira ao vapor de água e barreira UV/Visível e além disso, os filmes apresentaram atividade antioxidante proporcional a adição do extrato.

Filmes de gelatina bovina e de atum foram aditivados com extratos aquosos de orégano e alecrim. Observou-se que os filmes elaborados com as gelatinas bovina e a gelatina de peixe se comportaram de maneira diferente na presença dos polifenóis contidos nos extratos de orégano e alecrim. Os filmes de gelatina bovina aditivados com os extratos apresentaram propriedades semelhantes à formulação sem extrato, já os filmes de gelatina de peixe adicionados dos extratos de alecrim e orégano tiveram decréscimo em algumas propriedades, como a solubilidade, a permeabilidade e as propriedades mecânicas (GÓMEZ-ESTACA et al., 2009c). Gómez-Estaca et al. (2009a) também incorporaram extratos aquosos de orégano e alecrim em filmes de gelatina bovina e gelatina de atum e estudaram as propriedades antioxidantes dos filmes. Os autores constataram que o extrato aquoso de orégano conferiu maior propriedade antioxidante aos filmes de ambas macromoléculas. 
Moradi et al. (2012) trabalharam com filmes de quitosana adicionados de extrato comercial de sementes de uva. Estes autores observaram que a adição do extrato de semente uva diminuiu as propriedades mecânicas dos filmes, sendo que estes ficaram mais hidrofílicos (menores ângulos de contato). No entanto, a permeabilidade ao vapor de água permaneceu inalterada e, além disso, os filmes apresentaram poder antioxidante.

Em filmes de galactomanana adicionados de extrato etanólico de semente de acácia (Gleditsia triacanthos) foi observado que, a permeabilidade ao vapor de água (PVA), aumentou em função do aumento da concentração do extrato nos filmes. A atividade antioxidante também aumentou, assim como a coloração dos filmes (CERQUEIRA et al., 2010).

Extrato aquoso de chá verde foi adicionado em filmes à base de blendas de ágar e gelatina. Os filmes apresentaram atividade antioxidante e a permeabilidade ao vapor de água diminuiu com a adição do extrato (GIMÉNEZ et al., 2013). Siripatrawan e Harte (2010) trabalharam com filmes de quitosana com extrato aquoso de chá verde. Esses autores obtiveram filmes aditivados com melhores propriedades mecânicas que a formulação controle. Além disso, a PVA dos filmes diminuiu e foi constatada atividade antioxidante devido a adição do extrato.

Filmes de gelatina de peixe apresentaram incremento nas propriedades mecânicas e diminuição da permeabilidade ao vapor de água, quando adicionados de extrato de algas marinhas. A solubilidade dos filmes também diminuiu, os autores relataram a ocorrência de ligações entre fenóis oxidados presentes no extrato e as cadeias polipeptídicas de gelatina (RATTAYA; BENJAKUL; PRODPRAN, 2009). Norajit, Kim e Ryu (2010) desenvolveram filmes ativos a base de alginato contendo extrato hidroetanólico de ginseng e obtiveram filmes menos resistentes, porém com excelentes propriedades antioxidantes.

Extratos hidroetanólicos de canela, cravo e anis foram adicionados em filmes de gelatina de peixe e provocaram, de maneira geral, um aumento nas propriedades mecânicas e uma diminuição na permeabilidade ao vapor de água. Além disso, os filmes apresentaram maior pigmentação com a adição do extrato (HOQUE; BENJAKUL; PRODPRAN, 2011). Assim como no estudo de Rattaya, Benjakul e Prodpran (2009), os autores reportaram as melhorias obtidas neste estudo à interações entre os compostos fenólicos presentes nos extratos e as cadeias polipeptídicas de gelatina.

Li et al. (2014) estudaram a adição de extratos comerciais de chá verde, semente de uva, gengibre e ginkgo em filmes de gelatina e reportaram que em todos os casos foram 
produzidos filmes ativos com propriedades mecânicas ligeiramente inferiores à formulação controle.

Bitencourt et al. (2014) trabalharam com filmes de gelatina suína e relataram melhorias nas propriedades mecânicas e nas solubilidades dos filmes, quando estes foram aditivados com extrato etanólico de cúrcuma. Também foi reportada a atividade antioxidante dos filmes que aumentou proporcionalmente ao aumento na concentração do extrato nas formulações.

Além da produção de filmes ativos, pode-se, devido à presença de compostos fenólicos, observa-se que em alguns casos foi possível melhorar as propriedades físicoquímicas destes materiais (BIFANI et al., 2007; BITENCOURT et al., 2014; HOQUE; BENJAKUL; PRODPRAN, 2011; RATTAYA; BENJAKUL; PRODPRAN, 2009; SIRIPATRAWAN; HARTE, 2010;). De acordo com Wang et al. (2012), a adição de compostos fenólicos em materiais proteicos pode provocar alterações químicas que implicariam em um rearranjo estrutural das cadeias polipeptídicas. 


\section{Objetivos e hipótese}

O objetivo geral deste trabalho foi o desenvolvimento de filmes à base de colágeno ou gelatina adicionados de extrato de boldo-do-Chile com propriedades físicas e funcionais para emprego como embalagens bioativas.

Os objetivos específicos foram:

- Avaliação das condições de extração e das propriedades antioxidantes do extrato aquoso de boldo-do-Chile;

- Estudo das propriedades térmicas e reológicas das soluções filmogênicas elaboradas com gelatina e colágeno adicionadas de extrato de boldo-do-Chile

- Estudo das relações entre as propriedades mecânicas, umidade e solubilidade dos filmes e a adição do extrato em diferentes concentrações de macromoléculas e de extrato de boldo-do-Chile;

- Caracterização complementar das propriedades dos filmes de gelatina e colágeno produzidos com diferentes concentrações de extrato de boldo-do-Chile.

A hipótese considerada neste projeto é que a adição do extrato de boldo-do-Chile na formulação da solução filmogênica produzirá filmes com atividade antioxidante e possivelmente com propriedades mecânicas melhoradas, uma vez que os polifenóis presentes nesse extrato podem provocar rearranjos estruturais nas macromoléculas. 


\section{Material e Métodos}

\subsection{Material}

Para a execução desse projeto, foi utilizado colágeno em pó, doado pela Novaprom Food Ingredients Ltda, e gelatina de pele suína, do Tipo A, adquirida da indústria Gelita do Brasil Ltda (São Paulo, Brasil); e glicerol, como plastificante (Synth). O extrato de boldo-do-Chile foi produzido a partir de folhas secas adquiridas no mercado local, da marca Flores e Ervas (Florien LTDA). A origem e produção das plantas são desconhecidas. A gelatina e o plastificante foram utilizados sem nenhum tratamento prévio. Para o acondicionamento dos filmes, foram utilizados nos dessecadores, solução saturada de brometo de sódio (Synth). Para a produção das soluções de colágeno foi utilizado ácido acético para o abaixamento do $\mathrm{pH}$.

Também foram utilizados reagente de Folin-Ciocalteu (Merck), carbonato de sódio (Merck), ácido gálico (Sigma Aldrich), 2,2-difenil-1-picrilidrazil (DPPH) (Sigma Aldrich), 2,2'-azinobis(3-etilbenzotiazolina-6-ácido sulfônico) (ABTS) (Sigma Aldrich), persulfato de potássio (Merck), etanol anidro (Dinâmica) e trolox (Sigma Aldrich).

Para as análises cromatográficas foram utilizados ácido fórmico, acetonitrila e metanol (Qualidade LC/MS, Carlo Erba). Os padrões utilizados foram catequina, epicatequina, isorhamnetina, boldina, rutina, quercetina e kaempferol (Sigma Aldrich).

\subsection{Teor de aminoácidos da gelatina e do colágeno}

A determinação do teor de aminoácidos na gelatina e no colágeno foi realizado no laboratório Labtec (Hortolândia - SP). A análise foi realizada por cromatografia líquida de alta eficiência (HPLC) segundo a metodologia descrita por Hagen, Frost e Augustin (1989). As análises foram realizadas em duplicata.

\subsection{Preparo do extrato aquoso de boldo-do-Chile}

O extrato de boldo-do-Chile foi preparado com as folhas, de acordo com adaptações da metodologia utilizada por Bifani et al. (2007). As folhas de boldo-do-Chile 
foram trituradas e peneiradas (mesh 48) para padronização da granulometria. $\mathrm{O}$ extrato foi produzido com $5 \mathrm{~g}$ de pó de boldo-do-Chile em $50 \mathrm{~mL}$ de água destilada, sob agitação mecânica (TE039 Tecnal) em banho ultratermostatizado (MA 184 Marconi) durante 30 minutos (Figura 2a). Após o resfriamento dos extratos, esses foram filtrados (filtro Whatman $n^{\circ} 1$ ) e armazenados em frascos âmbar em geladeira (Figura 2b). Os extratos preparados foram utilizados em um período máximo de 24 horas. A extração foi realizada em quatro temperaturas diferentes $\left(30,45,60\right.$ e $\left.90^{\circ} \mathrm{C}\right)$, o objetivo foi verificar se havia efeito da temperatura de extração sobre as propriedades estudadas para os extratos produzidos.

Figura 2: Produção dos extratos de boldo-do-Chile (a) extração em banho termostatizado (b) filtração do extrato.
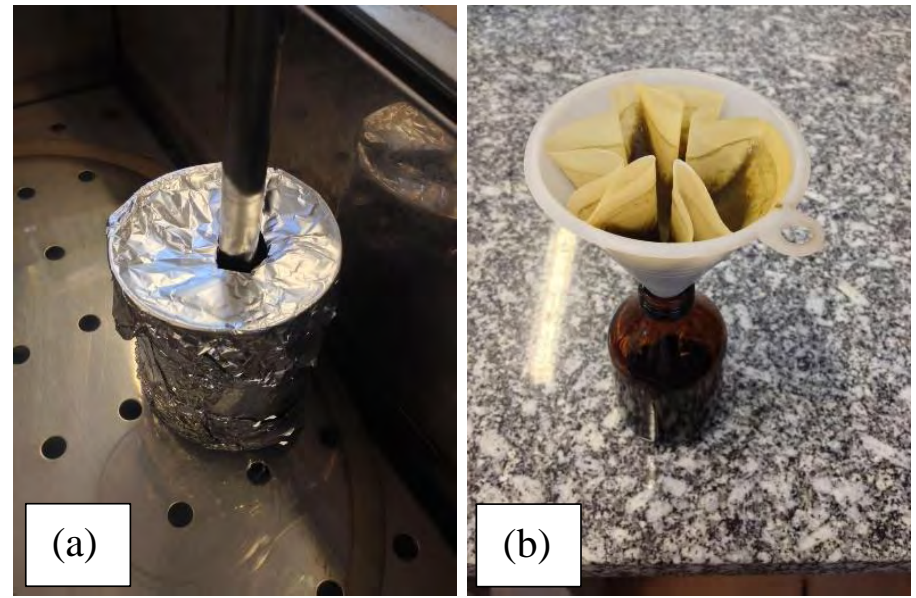

Fonte: Própria autoria

\subsection{Caracterização do extrato de boldo-do Chile}

Os extratos produzidos nas quatro temperaturas foram caracterizados com relação à cor, $\mathrm{pH}$, teor de sólidos solúveis e ao seu poder antioxidante (fenólicos totais, DPPH e ABTS). Para a realização das análises que mesuraram o potencial antioxidante a concentração dos extratos foi normalizada, ou seja, baseando-se no ${ }^{\circ}$ Brix diluíram-se os extratos de modo que todos ficassem com o mesmo teor de sólidos solúveis. Como análise microbiológica, foi realizado teste de sensibilidade de poço de difusão. A identificação dos compostos fenólicos foi realizada por UHPLC-DAD-MS. As metodologias utilizadas encontram-se descritas nos tópicos a seguir. 


\subsubsection{Teor de sólidos solúveis $\left({ }^{\circ} \mathrm{Brix}\right)$, $\mathrm{pH}$ e cor}

A análise de cor foi realizada nos extratos líquidos utilizando-se uma célula de quartzo. As amostras foram colocadas na célula, com o auxílio de um aparato para controlar a altura de líquido dentro da célula. A análise foi realizada com um colorímetro Miniscan XE (HunterLab), os parâmetros de cor do padrão CIELab (L*, a*, b*) foram determinados com cinco medidas para cada replicata.

Para a determinação do $\mathrm{pH}$, foram realizadas três medidas sucessivas em cada replicata em um potenciômetro de bancada (modelo PG 2000, Gehaka) (AOAC, 1995).

A determinação de sólidos solúveis foi feita por refratometria, utilizando um refratômetro de bancada, à $25^{\circ} \mathrm{C}$. A resposta foi expressa em ${ }^{\circ}$ Brix. Foram realizadas três medidas para cada replicata.

\subsubsection{Fenólicos totais (Método de Folin-Ciocalteau)}

O teor de compostos fenólicos totais foi determinado pelo método espectrofotométrico de Folin-Ciocalteau, utilizando-se ácido gálico como padrão de referência. Este método colorimétrico baseia-se na redução dos ácidos fosfomolíbdico e fosfotúngstico em solução alcalina. O reagente de Folin-Ciocalteau oxida os fenolatos, reduzindo os ácidos a um complexo azul Mo-W (Molibdênio-Tungstênio) que foi quantificado espectrofotometricamente à 750nm (MUNIZ; MATTOS; MORETTI, 2012; NEVES; ALENCAR; CARPES, 2009; SINGLETON; ROSSI, 1965).

Para essa análise, os extratos foram diluídos em água em duas concentrações (10 e $20 \mu \mathrm{L} / \mathrm{mL}$ ), os reagentes foram preparados de acordo com o protocolo utilizado por Singleton e Rossi (1965). Utilizando-se tubos de ensaio, à $250 \mu \mathrm{L}$ de amostra diluída foram adicionados $2 \mathrm{~mL}$ de água destilada e $250 \mu \mathrm{L}$ do reagente de Folin-Ciocalteau. Decorridos 3 minutos, adicionaram-se $250 \mu \mathrm{L}$ de carbonado de sódio $\left(\mathrm{Na}_{2} \mathrm{CO}_{3}\right)$. Os tubos de ensaio contendo as amostras foram mantidos por 30 minutos à $37^{\circ} \mathrm{C}$ por 30 minutos. Então, foi realizada a leitura em um espectrofotômetro UV/Visível (Lambda 35, Perkin Elmer) à 750nm. O cálculo da concentração de compostos fenólicos foi realizado a partir da curva padrão, elaborada com soluções de ácido gálico em concentrações que variaram de 0 a $0,080 \mathrm{mg} / \mathrm{mL}$. O resultado foi expresso em $\mathrm{mg}$ de ácido gálico/mL de extrato. 


\subsubsection{Atividade sequestrante do radical livre DPPH (DPPH•)}

O método utilizando o radical livre DPPH é usualmente aplicado por ser um método rápido, prático e com boa estabilidade. Assim, foi possível avaliar a atividade antioxidante baseando-se na capacidade dos extratos em sequestrar radicais livres (BRAND-WILLIANS; CUVELIER; BERSET, 1995; PRADO, 2009; SUCUPIRA et al., 2012). Para a realização das análises, primeiramente deve-se determinar o tempo de estabilização, que consiste no tempo mínimo em que o extrato deve permanecer em contato com o radical proporcionando a maior redução possível. A redução do radical DPPH foi monitorada pelo decréscimo da absorbância durante a reação (BRANDWILLIANS; CUVELIER; BERSET, 1995; PRADO, 2009).

A molécula de 2,2-difenil-1-picrilidrazil (DPPH) caracteriza-se como um radical livre estável, caracterizado pela cor violeta escuro e que possui uma banda de absorção, quando diluído em etanol, entre 515 e 520nm (BONDET; BRAND-WILLIAMS; BERSET, 1997; MOLYNEUX, 2004). Quando uma solução de DPPH é misturada com um agente que seja capaz de doar um átomo de hidrogênio, ela dá origem à forma reduzida, que perde a cor violeta tornando-se amarelo pálido (Figura 3) (MOLYNEUX, 2004).

Figura 3: Estrutura química e reação com um antioxidante.

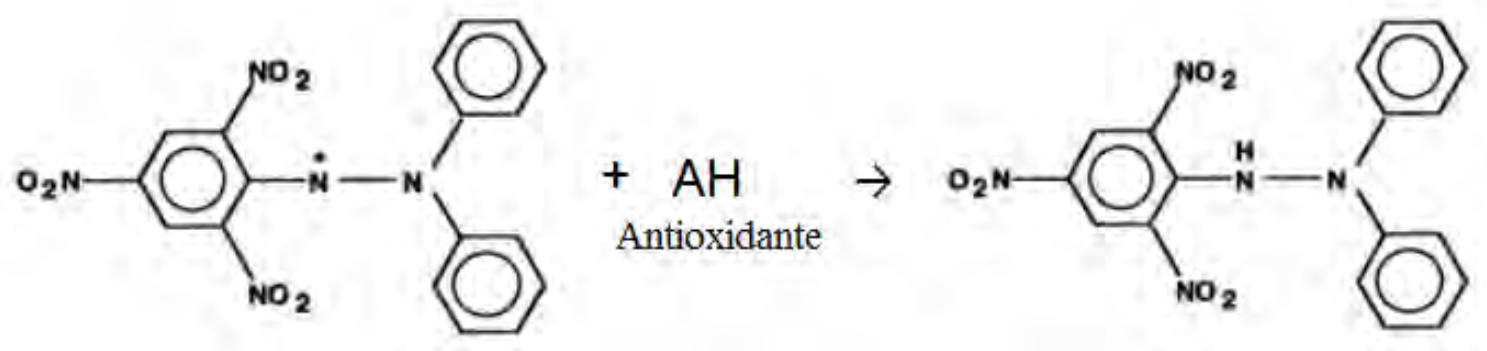

Fonte: MOLYNEUX, P. The use of the stable free radical diphenylpicrylhydrazyl (DPPH) for estimating antioxidant activity. Songklanakarin Journal of Food Science and Technology, v. 26, n. 2, p. 211-219, 2004.

As análises foram realizadas seguindo o protocolo analítico de Rufino et al. (2007). Uma solução etanólica de 2,2-difenil-1-picrilidrazil (DPPH) foi preparada na concentração de $60 \mu \mathrm{M}$, sendo armazenada ao abrigo da luz. Foram preparadas 10 diluições das amostras em etanol anidro (99\%), em concentrações que variaram de 5 a 
$50 \mu \mathrm{L} / \mathrm{mL}$. Em tubos de ensaio foram colocados $0,1 \mathrm{~mL}$ das amostras diluídas juntamente com 3,9mL de solução DPPH. Como branco, $0,1 \mathrm{~mL}$ das amostras foram diluídos com 3,9mL de etanol anidro (99\%). As leituras foram realizadas em espectrofotômetro UV/Visível (Lambda 35, Perkin Elmer) à 515nm. O cálculo do índice EC 50 foi realizado a partir da inibição da absorbância inicial da solução de DPPH, sendo obtida a concentração do extrato que seja capaz de inibir $50 \%$ do poder oxidante do reagente $\mathrm{DPPH}$, esse resultado foi expresso em $\mathrm{mL}$ de extrato/L de etanol.

\subsubsection{Atividade antioxidante pelo método ABTS $\left(\mathrm{ABTS}^{+\bullet}\right)$}

A análise da atividade antioxidante pelo método ABTS 2,2'- azinobis(3etilbenzotiazolina-6-ácido sulfônico) consiste em avaliar a capacidade dos extratos em capturar o cátion $\mathrm{ABTS}^{+\bullet}$, reação que provoca um decréscimo na absorbância (RUFINO et al., 2007; SUCUPIRA et al., 2012).

O radical ABTS é um composto quimicamente estável, possui alta solubilidade em água, e que pode ser gerado por reações enzimáticas ou químicas, apresentando um máximo de absorbância a 414nm, e de medidas secundárias de absorbância a 645, 734 e 815nm (RE et al., 1999).

Entretanto, existem outras maneiras de se obter esse radical, como por exemplo, a partir da oxidação do persulfato de potássio $\left(\mathrm{K}_{2} \mathrm{~S}_{2} \mathrm{O}_{8}\right)$, sendo que a reação ocorre por um período de 12 a 16 horas, em ausência de luz. Assim, produz-se o radical ABTS, que apresenta cor azul esverdeado, que com a adição de um agente antioxidante perde a coloração. Com a perda de cor, a porcentagem de inibição do $\mathrm{ABTS}^{+\bullet}$ é determinada em função do Trolox, que é o padrão utilizado e submetido às mesmas condições analíticas do antioxidante (PRADO, 2009; RE et al., 1999; RUFINO et al., 2007; SUCUPIRA et al., 2012).

O radical ABTS utilizado nas análises foi produzido por oxidação do persulfato de potássio. Os extratos de boldo-do-Chile analisados foram previamente diluídos (10 e $30 \mu \mathrm{L} / \mathrm{mL}$ ) em etanol (99\%), em seguida, as soluções foram centrifugadas em uma centrifuga refrigerada (Thermoiec, CENTRAGP8R, EUA), a $4000 \mathrm{rpm}$, por 5 minutos. Em tubos de ensaio, foram colocados $30 \mu \mathrm{L}$ das diluições e em seguida foram adicionados os $3 \mathrm{~mL}$ do reagente ABTS previamente diluído em etanol $(99 \%)(\sim 2,1 \mathrm{~mL}$ de reagente em 100mL de etanol). Após o tempo de reação da amostra com o radical ABTS (6 
minutos), as amostras foram analisadas em um espectrofotômetro UV/Visível (Lambda 35, Perkin Elmer, EUA), com um comprimento de onda de 734nm. Como branco, foram utilizados os mesmos $30 \mu \mathrm{L}$ de amostra, no entanto, foram adicionados $3 \mathrm{~mL}$ de etanol (RE et al., 1999; RUFINO et al., 2007).

Para os cálculos da atividade antioxidante foi construída uma curva padrão com Trolox (agente antioxidante sintético) e etanol, com 10 diluições que variaram de (25 a $2500 \mu \mathrm{mol} / \mathrm{L}$ ) e as leituras também foram realizadas à $734 \mathrm{~nm}$. Os resultados foram expressos em TROLOX equivalente, ou seja, mg de Trolox/mL de extrato, representando o quanto o extrato de boldo-do-Chile se comportou como o antioxidante Trolox, frente ao oxidante ABTS (RE et al., 1999; RUFINO et al., 2007).

\subsubsection{Análise microbiológica: Teste de Sensibilidade pelo Método de Poço Difusão}

Para a realização das análises de determinação da atividade antimicrobiana dos extratos aquosos de boldo-do-Chile, foram escolhidas as temperaturas com maior atividade antioxidante $\left(45,60\right.$ e $\left.90^{\circ} \mathrm{C}\right)$ e foram utilizadas quatro cepas das seguintes bactérias: Escherichia coli, ATCC 25922; Pseudomonas aeruginosa, ATCC 15442; Salmonella spp, ATCC 13076 e Staphylococcus aureus, ATCC 25923.

Os testes foram realizados a partir do testes de sensibilidade por meio do método de poço difusão de acordo com DUARTE et al., (2007) e MARTIN (2012). Dessa forma, os extratos foram filtrados em membranas com porosidade de $22 \mu \mathrm{m}$ e $33 \mathrm{~mm}$ de diâmetro, previamente autoclavadas, para assegurar a esterilidade dos mesmos. Após a filtragem, os extratos foram diluídos nas seguintes proporções: $100 \%$ (2mL de extrato), $75 \%$ (1,5mL de extrato e $0,5 \mathrm{~mL}$ de água destilada filtrada), $50 \%$ ( $1 \mathrm{~mL}$ de extrato e $1 \mathrm{~mL}$ de água destilada filtrada), $25 \%$ ( $0,5 \mathrm{~mL}$ de extrato e $1,5 \mathrm{~mL}$ de água destilada filtrada), $10 \%$ ( $0,2 \mathrm{~mL}$ de extrato e $1,8 \mathrm{~mL}$ de água filtrada) e $0 \%$ (apenas $2 \mathrm{~mL}$ de água destilada filtrada). Para o preparo do controle positivo, homogeneizou-se uma cápsula de clorafenicol (antibiótico) em $20 \mathrm{~mL}$ de água destilada filtrada em membrana com porosidade de $22 \mu \mathrm{m}$ e 33mm de diâmetro, previamente autoclavada.

Após o cultivo de $1 \mathrm{~mL}$ das cepas em $10 \mathrm{~mL}$ de caldo BHI (Bacillus cereus, Bacillus subitilis, Escherichia coli, Salmonella spp e Staphylococcus aureus) ou TSB (Pseudomonas aeruginosa) a $37^{\circ} \mathrm{C}$ por 24 horas, as suspensões bacterianas foram ajustadas em espectrofotômetro no comprimento de onda em $625 \mathrm{~nm}$ com a utilização da 
escala de Mac Farland 0,5Mac, que corresponde a 0,08 a 0,10 de absorbância, ou seja 1 a $2 \times 10^{8} \mathrm{UFC} / \mathrm{mL}$. Posteriormente, $200 \mu \mathrm{L}$ do inóculo padronizado foi homogeneizado em $200 \mathrm{~mL}$ de meio ágar Muller Hilton, previamente autoclavado e mantido a $45^{\circ} \mathrm{C}-50^{\circ} \mathrm{C}$, para a obtenção de uma concentração bacteriana de 1,5 x 10 $10^{5} \mathrm{UFC} / \mathrm{mL}$.

Os poços foram cortados como auxílio de uma ponteira de 1000uL estéril e descartável após a solidificação do ágar e, em seguida, a parte cortada foi retirada com o auxílio de uma ponteira de 100uL estéril e descartável. Os poços forma identificados com o número das diluições (Figura 4), e foram depositados $40 \mu \mathrm{L}$ das devidas soluções em seus respectivos poços. No poço central foi colocado o antibiótico Clorafenicol (controle positivo) e no poço de número 1 colocou-se água destilada (controle negativo).

Figura 4: Identificação dos poços segundo as diluições realizadas

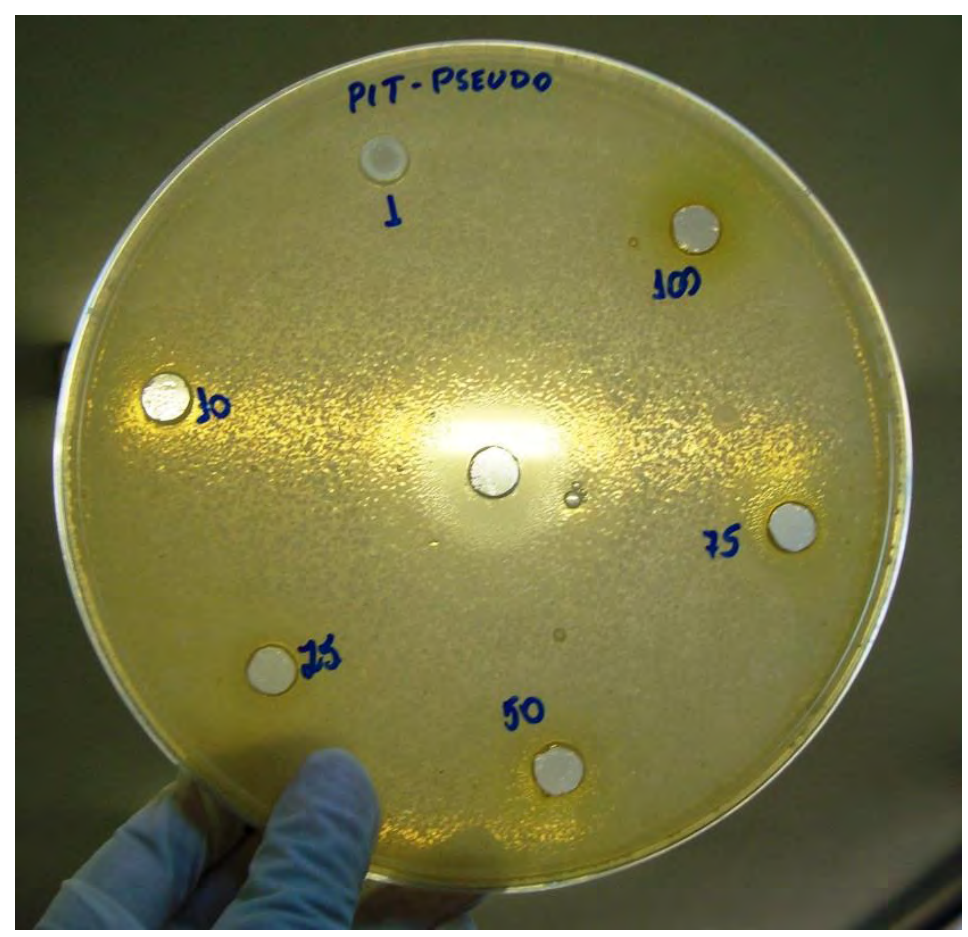

Fonte: Própria autoria

As placas permaneceram por 1 hora em temperatura ambiente para que o extrato pudesse se difundir no meio. Após esse período, as mesmas foram incubadas a $37^{\circ} \mathrm{C}$ por 24 horas para que se realizasse a medição dos halos formados (zona de inibição). 


\subsubsection{Identificação dos compostos por UHPLC-DAD-MS}

Para a realização das análises cromatográficas, o extrato foi produzido a partir de $2 \mathrm{~g}$ de pó de boldo-do-Chile adicionado de $20 \mathrm{~mL}$ de água ultrapura (System Simplicity 185, Millipore). O extrato foi produzido por agitação magnética em um banho maria com temperatura controlada $\left(30,45,60\right.$ ou $\left.90^{\circ} \mathrm{C}\right)$. Em seguida, o extrato foi colocado em tubos e centrifugados a $10.000 \mathrm{~g}$ durante 10 minutos, à temperatura ambiente, em uma centrífuga (Heraeus Biofuge fresco D 37520). O sobrenadante foi filtrado em filtros de Nylon de $0,22 \mu \mathrm{m}$ de porosidade (VWR) e levados para a análise cromatográfica. Cada extração foi realizada em triplicata.

A análise para identificação dos compostos foi realizada por cromatografia líquida de ultra-alta perfomance acoplada de um detector UV-Visível e um espectometro de massa (UHPLC-DAD-MS). A fase estacionária foi uma coluna Acquity UHPLC ${ }^{\circledR}$ BEH C18 (comprimento 10mm; diâmetro interno 2,1mm; partículas $1,7 \mu \mathrm{m}$ ) equipado com uma pré-coluna $(5 \times 2,1 \mathrm{~mm})$ Acquity Vaunguard de mesma qualidade e termostatizada à $30^{\circ} \mathrm{C}$. A metodologia foi adapatada da literatura encontrada para extratos de boldo-doChile produzidos com diferentes tipos de solvente, como metanol e água (FALÉ et al., 2012; SIMIRGIOTIS; SCHMEDA-HIRSCHMANN, 2010; SOTO et al. 2014).

A eluição foi realizada com um gradiente utilizando as fases móveis A (água contendo $0,1 \% \mathrm{v} / \mathrm{v}$ ácido fórmico) e B (acetonitrila contendo $0,1 \% \mathrm{v} / \mathrm{v}$ de ácido fórmico) (Tabela 3). A taxa de eluição empregada foi de $0,490 \mathrm{~mL} / \mathrm{min}$ e o volume injetado de $0,5 \mu \mathrm{L}$.

Tabela 3: Gradiente linear empregado nas análises UHPLC-DAD-MS $®$ dos extratos de boldo

\begin{tabular}{ccc}
\hline Tempo $(\mathbf{m i n})$ & $\mathbf{A ~ ( \% )}$ & $\mathbf{B}(\boldsymbol{\%})$ \\
\hline 0 & 90 & 10 \\
0,99 & 90 & 10 \\
6,70 & 80 & 20 \\
7,51 & 25 & 75 \\
15,67 & 25 & 75 \\
15,81 & 0 & 100 \\
17,50 & 0 & 100 \\
18,00 & 90 & 10 \\
20,00 & 90 & 10 \\
\hline
\end{tabular}


O espectro dos compostos eluídos foi medido entre 190 e 500nm com um detector DAD. As condições de ionização utilizadas em espectrometria de massa foram: tensão do capilar $-0,5 \mathrm{kV}$, tensão do cone $-40 \mathrm{~V}$, fonte de compensação - $80 \mathrm{~V}$, temperatura da fonte $-130^{\circ} \mathrm{C}$, temperatura de dessolvatação $-550{ }^{\circ} \mathrm{C}$, o fluxo do gás do cone $-50 \mathrm{~L} / \mathrm{h}$ e o fluxo do gás de dessolvatação $1200 \mathrm{~L} / \mathrm{h}$. A aquisição dos dados foi realizada em modo MS centroide em uma gama de m/z de 50 a 1200 com um tempo de aquisição de $0,2 \mathrm{~s} / \mathrm{scan}$. A energia de colisão de baixa energia e de alta energia foram, respectivamente, $6 \mathrm{eV}$ e de 15 a $45 \mathrm{eV}$. Os espectros de massa foram identificados com auxílio do software MassLynx ${ }^{\circledR}$.

\subsection{Elaboração das soluções filmogênicas}

Foram produzidas soluções filmogênicas (SF) com gelatina e colágeno, a metodologia utilizada para cada uma das macromoléculas empregadas encontra-se descrita a seguir.

Soluções de Gelatina: Primeiramente a gelatina foi hidratada durante 30 minutos, à temperatura ambiente. Em seguida, foi solubilizada em banho termostático (MA 184 Marconi) à $70^{\circ} \mathrm{C}$ por 15 minutos. Decorrido esse tempo, a solução foi colocada sob agitação magnética (TE 085 Tecnal) até que a temperatura atingisse $55^{\circ} \mathrm{C}$. Então, o extrato de boldo-do-Chile foi adicionado e a agitação magnética foi mantida por 5 minutos. Depois, o plastificante (glicerol) foi adicionado e manteve-se a agitação por mais 1 minuto para homogeneização.

Soluções de Colágeno: O colágeno foi solubilizado em água com $\mathrm{pH}=3$, ajustado com ácido acético glacial, sob agitação, por 30 minutos à $90^{\circ} \mathrm{C}$ em banho termostático (MA 184 Marconi) com agitação mecânica (TE 039 Tecnal) (WOLF; SOBRAL; TELIS, 2009). Decorrido esse tempo, a solução foi colocada sob agitação magnética (TE 085 Tecnal) e quando a temperatura atingiu $55^{\circ} \mathrm{C}$, foi adicionado o extrato de boldo-do-Chile, O tempo de homogeneização foi de 5 minutos. Por fim, o plastificante (glicerol) foi adicionado e a solução mantida sob agitação por mais 1 minuto.

Dessa forma, as soluções foram consideradas como preparadas para as caracterizações e/ou aplicação no suporte. 


\subsection{Caracterização das soluções filmogênicas de gelatina}

Este tópico trata das caracterizações das soluções filmogênicas de gelatina, segundo suas propriedades reológicas e suas propriedades térmicas.

\subsubsection{Propriedades reológicas das soluções de gelatina}

As propriedades viscoelásticas das soluções filmogênicas (SF) foram estudadas a fim de avaliar se a adição do extrato de boldo-do-Chile alterava as propriedades reológicas e térmicas destas soluções. As soluções filmogênicas foram preparadas com as seguintes formulações:

- Concentração de gelatina: 2, 4, 6 e $8 \mathrm{~g} / 100 \mathrm{~g} \mathrm{SF}$.

- $\quad$ Concentração de extrato de boldo: 0, 50 e $150 \mathrm{~g} / 100 \mathrm{~g}$ de gelatina.

- $\quad$ Concentração de glicerol: 30g/100g de macromolécula.

Os testes reológicos das soluções filmogênicas foram realizados em um reômetro (AR2000 Advanced Rheometer; TA Instruments, New Castle, DE, USA) utilizando a geometria de cone e placa ( $6 \mathrm{~cm}$ de diâmetro e ângulo de $2^{\circ}$ ) para os testes oscilatórios e a geometria de cilindros concêntricos para os testes estacionários. O equipamento conta com controle de temperatura e os resultados foram analisados com auxílio do software Rheology Advantage Data Analysis V.5.3.1 (TA Instruments).

Foram realizados testes dinâmicos com ensaios oscilatórios com tensão controlada, para a determinação das propriedades viscoelásticas: módulo de armazenamento (G') e módulo de perda (G”). Especificamente, foram realizados os ensaios descritos a seguir.

\subsubsection{Testes de varredura de deformação}

Os testes de varredura de deformação foram realizados para determinação do intervalo de viscoelasticidade linear. Por questões de limites técnicos do equipamento para as soluções à $50^{\circ} \mathrm{C}$, no domínio sol, as amostras foram analisadas com deformações variando entre $0-100 \%$, e para as amostras à $5^{\circ} \mathrm{C}$, no domínio gel, as amostras foram analisadas em deformações variando de 0 à $15 \%$, sendo que em ambos os casos a 
frequência utilizada foi constante e igual à $1 \mathrm{~Hz}$. O resultado desse teste determinou a deformação que foi usada nos testes posteriores (MORAES et al., 2009).

\subsubsection{Testes de varredura de temperatura}

As soluções filmogênicas (SF) foram colocadas na geometria do reômetro, onde permaneceu em repouso para relaxamento das tensões, durante 5 minutos. Em seguida a solução foi submetida a uma rampa de resfriamento de 50 até $5^{\circ} \mathrm{C}$, e de aquecimento de 5 à $50^{\circ} \mathrm{C}$. A taxa de variação da temperatura foi $2^{\circ} \mathrm{C} / \mathrm{min}$, e a taxa de deformação foi $2 \%$, que foi selecionada previamente. As temperaturas de transições TsOL-GEL, no resfriamento, e $\mathrm{T}_{\mathrm{GEL}-\mathrm{SOL}}$, no aquecimento foram obtidas como a partir da primeira derivada do módulo de armazenamento em função da temperatura (JORGE et al. 2014; MORAES et al., 2009; PERESSINI et al., 2003).

\subsubsection{Testes de varredura de frequência}

Assim como para os demais testes realizados, uma vez colocadas na geometria do reômetro as soluções filmogênicas permaneceram 5 minutos em repouso, para relaxamento das tensões. As amostras foram resfriadas $\left(2^{\circ} \mathrm{C} / \mathrm{min}\right)$ até $5^{\circ} \mathrm{C}$, para a formação dos géis e estes foram submetidos aos testes de varredura de frequência que variou de 0,01 a 10Hz (VALENCIA et al., 2015). A evolução de G' em função da frequência forneceu informações sobre o tipo de gel formado a partir das soluções filmogênicas (HELLIO-SERUGHETTI; DJABOUROV 2006a,b)

\subsubsection{Curvas de fluxo}

As curvas de fluxo das soluções filmogênicas foram obtidas por testes estacionários. Esses testes foram realizados à a $50^{\circ} \mathrm{C}$, garantindo-se que a solução permaneceu sempre na região sol (MORAES et al., 2009; PERESSINI et al., 2003). O intervalo de taxa de deformação escolhido variou de 0 a $200 \mathrm{~s}^{-1}$, e as amostras foram submetidas a três rampas de taxa de deformação, sendo estas: crescente, decrescente e crescente, com duração de dois minutos cada (JORGE et al., 2014; VALENCIA et al., 
2015). A resposta obtida das curvas de fluxo para as SF foi a viscosidade ( $\mu, \mathrm{mPa} . \mathrm{s})$, isso porque estas se tratarem de fluidos Newtoniano.

\subsubsection{Testes oscilatórios ao longo do tempo}

Os testes oscilatórios ao longo do tempo avaliaram o comportamento das soluções ao longo do tempo. Os testes foram realizados $50^{\circ} \mathrm{C}$ (domínio sol), mantendo-se constantes a frequência $(1 \mathrm{~Hz})$ e a taxa de deformação $(2 \%)$, foram realizadas medidas oscilatórias por até $5 \mathrm{~h}$ de modo que a solução permanecesse na fase sol. Assim, foram feitas medidas oscilatórias por até 5h. A presença de inflexões nos gráficos dos módulos de armazenamento $\left(G^{\prime}\right)$ ou perda (G”) ao logo do tempo sugere que houve mudança de comportamento que podem indicar a formação de novas ligações intermoleculares (HELLIO-SERUGHETTI; DJABOUROV, 2006a).

\subsubsection{Análises térmicas das soluções filmogênicas de gelatina}

As análises térmicas foram realizadas utilizando um microDSC SETARAM (Caluire-France) equipado com uma célula de grande volume (1000mg de solução de gelatina). A análise térmica foi realizada segundo as etapas descritas a seguir:

- Isoterma à $50^{\circ} \mathrm{C}$ durante 5 minutos;

- Resfriamento até $5^{\circ} \mathrm{C}$ com uma velocidade de $1^{\circ} \mathrm{C} / \mathrm{min}$;

- Isoterma à $5^{\circ} \mathrm{C}$ por diferentes períodos (30, 60 e 90 minutos).

- Aquecimento do gel até $50^{\circ} \mathrm{C}$ com velocidade de $1^{\circ} \mathrm{C} / \mathrm{min}$.

A partir dessa análise foi possível determinar a temperatura e a entalpia de fusão $(\Delta \mathrm{H} \mathrm{em} \mathrm{J/g)}$ para as diferentes soluções elaboradas com e sem extrato de boldo-do-Chile.

Realizados esses ensaios, foi escolhida uma concentração de gelatina para elaboração de uma solução filmogênica a ser submetida à uma isoterma de 240 minutos à $5^{\circ} \mathrm{C}$. Essa análise foi realizada para verificar o possível efeito do tempo nas propriedades térmicas. 


\subsection{Caracterização das soluções filmogênicas de colágeno}

As soluções filmogênicas (SF) elaboradas com colágeno produzidas ao longo desta tese mostraram-se, na verdade, sistemas particulados (Figura 5) mesmo para a menor concentração de macromolécula ( $2 \mathrm{~g}$ de colágeno/100g de SF). Além disso, havia precipitação de partículas ao longo do tempo, diminuindo a reprodutibilidade dos resultados. Assim, optou-se pela não realização das análises térmicas das SF de colágeno, sendo realizado somente um teste reológico (estudo do efeito do espaçamento) que será descrito no próximo tópico.

Figura 5: Imagem de uma solução de colágeno com $2 \mathrm{~g}$ de colágeno/100g de SF

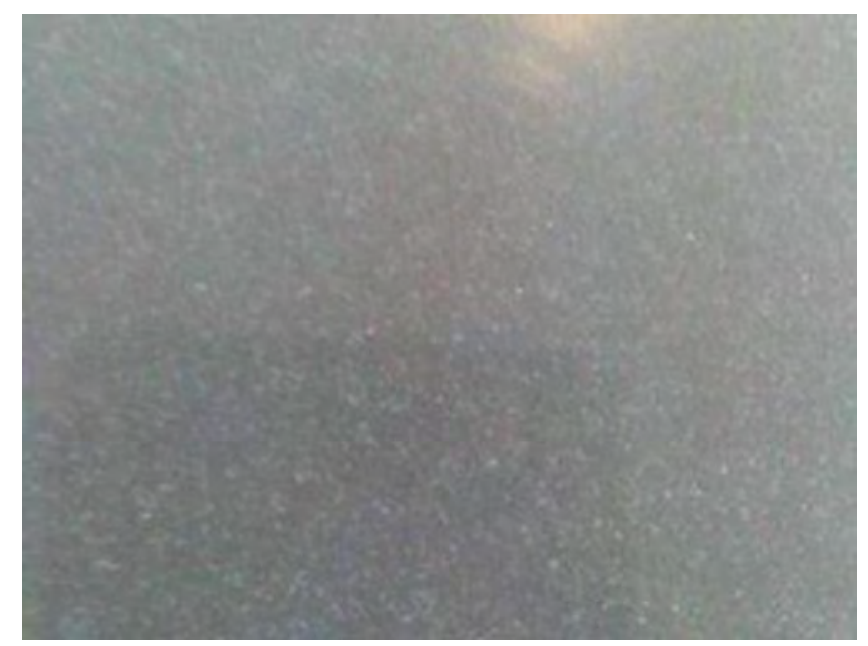

Fonte: Própria autoria.

As soluções de colágeno foram submetidas a testes oscilatórios de varredura de tensão. A geometria utilizada foi a placa plana com $6 \mathrm{~cm}$ de diâmetro, após ser colocada no equipamento, a amostra de solução filmogênica foi mantida em repouso (5 minutos), para relaxamento das tensões. Foi realizada uma varredura de tensão de 0 a $3 \mathrm{~Pa}$, a temperatura foi mantida à $50^{\circ} \mathrm{C}$ e a frequência $1 \mathrm{~Hz}$. O espaçamento ("gap") variou de 1000 à 2000mm para que fosse observado efeito do gap sobre o G' e o G” em função da variação da tensão. O espaçamento ideal é aquele em que não há variação nos módulos G' e G” (ALBANO; FRANCO; TELIS, 2014). 


\subsection{Preparo e caracterização dos filmes}

Os filmes foram produzidos pela técnica "casting" que consistiu na dispersão da solução filmogênica em placas de poliestireno $(\mathrm{d}=150 \mathrm{~mm})$. Os filmes foram submetidos à secagem por $24 \mathrm{~h}$, a $30^{\circ} \mathrm{C}$ em estufa com circulação de ar (MA 037 - TECNAL). Após isso, os filmes foram preparados, de acordo com os testes a serem realizados, e em seguida, acondicionados em dessecadores contendo solução saturada de $\mathrm{NaBr}$ (58\% de umidade relativa), a $25^{\circ} \mathrm{C}$, por 7 dias, antes de serem caracterizados.

\subsubsection{Espessura}

A espessura dos filmes foi determinada como a média aritmética de dez medidas aleatórias feitas com um micrômetro digital (resolução 0,001mm, MITUTOYO) (THOMAZINE; CARVALHO; SOBRAL, 2005).

\subsubsection{Propriedades mecânicas}

As propriedades mecânicas dos filmes foram avaliadas por testes de tração e perfuração utilizando-se um texturômetro iCON Texture analyser (TA Instruments). Os dados foram analisados com auxílio do Exponent Lite Express (versão 4,013,0 XT Express).

\subsubsection{Testes de tração}

Para os testes de tração, foram preparadas amostras de 15 x $90 \mathrm{~mm}^{2}$ que foram fixas na sonda de tração com separação inicial de 50mm, e a velocidade de realização do teste foi estabelecida em 1,0mm/s. A tensão na ruptura (TR, em MPa) e a elongação na ruptura (ER, em \%) foram obtidas diretamente das curvas de tensão versus elongação, já, o módulo elástico (ME, em MPa/\%) foi obtido a partir do cálculo da inclinação da porção linear da curva (ASTM D882 - 10, 2010b). 


\subsubsection{Testes de perfuração}

Os testes de perfuração foram realizados segundo Sobral et al. (2001), onde amostras circulares $(\mathrm{d}=46 \mathrm{~cm})$ foram colocadas em um suporte cilíndrico e perfuradas por uma sonda $(\mathrm{d}=3 \mathrm{~cm})$ com velocidade de $1 \mathrm{~mm} / \mathrm{s}$. A força na perfuração $(\mathrm{FP}$, em $\mathrm{N})$ foi obtida da curva força versus distância (mm). A deformação na perfuração (DP, em \%) foi calculada a partir da distância percorrida pela sonda, com a equação 1 .

$$
\text { Deformação }(\%)=\left[\frac{\left(\sqrt{d^{2}+1_{0}^{2}}-1_{0}\right)}{1_{0}}\right] \times 100
$$

Onde:

d é a distância percorrida pela sonda, em mm;

$l_{0}$ é o comprimento inicial do filme (raio $=23 \mathrm{~mm}$ ).

\subsubsection{Umidade e Solubilidade em Água}

A determinação da umidade foi feita por gravimetria. As amostras dos filmes foram colocadas em pesa filtros e levadas à estufa à $105^{\circ} \mathrm{C}$ por 24 horas (GONTARD; GUILBERT; CUQ, 1992).

A determinação da solubilidade em água dos filmes foi realizada segundo adaptações da metodologia de Gontard, Guilbert e Cuq (1992). As amostras foram cortadas em discos $(\mathrm{d}=2 \mathrm{~cm})$ e colocadas em $50 \mathrm{~mL}$ de água, permanecendo sob agitação durante 24 horas. Decorrido esse período, o material restante foi recuperado, colocado em pesa filtro e seco em estufa à $105^{\circ} \mathrm{C}$ por mais 24 horas. A solubilidade foi calculada com a equação 2 .

$$
\text { Solubilidade }(\%)=\left(\frac{m_{i}-m_{f}}{m_{i}}\right) \times 100
$$

Onde:

$\mathrm{m}_{\mathrm{i}}$ é a massa seca inicial do filme, em g;

$\mathrm{m}_{\mathrm{f}}$ é a massa seca final do filme, após o teste de solubilidade, em $\mathrm{g}$. 


\subsubsection{Cor e opacidade}

A cor dos filmes foi medida por meio dos padrões do CIELab: L* luminosidade, variando de 0 (preto) a 100 (branco); $\mathrm{a}^{*}$ de verde (-) à vermelho (+); e b*, de azul (-) à amarelo (+) (Figura 6), determinados com um colorímetro Miniscan XE (HunterLab), trabalhando com D65 e luz do dia, com o auxílio do programa Universal Software 3.2 (HunterLab Associates Laboratory). Os filmes foram colocados na placa branca e foram realizadas 10 medidas aleatórias. A diferença total de cor $\left(\Delta \mathrm{E}^{*}\right)$ foi determinada com a equação 3 (ASTM D2244 - 11, 2011).

Figura 6: Representação gráfica da variação das cores para os parâmetros L*, a* e b* (CIELab)

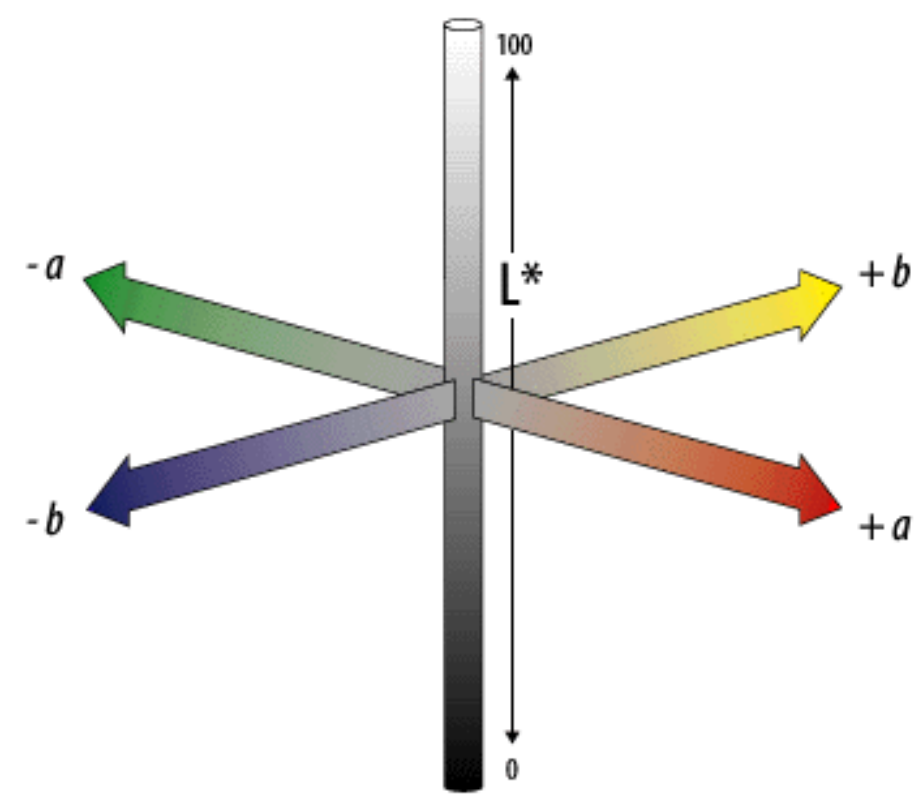

Fonte: CIELAB. Representação do sólido de cores. Disponível em:< http://dba.med.sc.edu/price/irf/Adobe_tg/models/cielab.html.>. Acesso em: 29 de setembro de 2015.

$$
\Delta \mathrm{E}^{*}=\sqrt{\left(\Delta \mathrm{L}^{*}\right)^{2}+\left(\Delta \mathrm{a}^{*}\right)^{2}+\left(\Delta \mathrm{b}^{*}\right)^{2}}
$$

Onde:

$\Delta \mathrm{L}^{*}=\mathrm{L}^{*}{ }_{\text {amostra }}-\mathrm{L}^{*}$ padrão;

$\Delta \mathrm{a}^{*}=\mathrm{a}^{*}{ }_{\text {amostra- }} \mathrm{a}^{*}$ padrão;

$\Delta \mathrm{b}^{*}=\mathrm{b}^{*}{ }_{\text {amostra- }} \mathrm{b}^{*}$ padrão 


\subsection{Caracterizações complementares dos filmes}

Para a realização das caracterizações complementares dos filmes foi escolhida uma formulação. A escolha baseou-se nos testes realizados (propriedades mecânicas, solubilidade, umidade, cor e opacidade) e também na maquinabilidade durante a produção dos filmes.

A formulação com maior concentração de macromoléculas $(8 \mathrm{~g} / 100 \mathrm{~g}$ de $\mathrm{SF})$ apresentou propriedades mecânicas superiores quando comparada às outras formulações, sem diferença nos outros parâmetros já mencionados. No entanto, durante a elaboração dos filmes a incorporação de bolhas de ar, e a dificuldade de solubilização das macromoléculas fizeram com que a formulação escolhida fosse a que continha $6 \mathrm{~g}$ de macromoléculas $/ 100 \mathrm{~g}$ de SF. Assim, as análises descritas nos tópicos seguintes foram realizadas em filmes de gelatina ou colágeno, sem adição de extrato de boldo-do-Chile (controle) e com 50 e $150 \mathrm{~g}$ de extrato de boldo-do-Chile/100g de macromoléculas.

\subsubsection{Análises térmicas por calorimetria diferencial de varredura}

As análises térmicas dos filmes foram realizadas utilizando-se um calorímetro diferencial de varredura modelo DSC TA 2010. As amostras de filmes, previamente acondicionadas em dessecadores com sílica-gel (3 semanas), foram pesadas ( $\pm 10 \mathrm{mg}) \mathrm{em}$ cápsulas de alumínio, hermeticamente fechadas. As cápsulas foram aquecidas, juntamente com uma cápsula vazia como referência, a $10^{\circ} \mathrm{C} / \mathrm{min}$, de -150 a $150^{\circ} \mathrm{C}$, em uma atmosfera inerte $\left(45 \mathrm{~mL} / \mathrm{min}\right.$ de $\left.\mathrm{N}_{2}\right)$. Após a primeira varredura de temperatura, as cápsulas foram resfriadas rapidamente, utilizando-se nitrogênio líquido e uma segunda varredura foi realizada nas mesmas condições da primeira. A temperatura de transição vítrea (Tg) (ponto médio), a temperatura de fusão $(\mathrm{Tm})$ (pico) e a entalpia de fusão $(\Delta \mathrm{H}$ em J/g de macromoléculas) foram calculadas pelo programa Universal Analysis V1.7F software (TA Instruments) (ALVES et al., 2011; SOBRAL et al., 2001). 


\subsubsection{Análises de cristalinidade por difratometria de raio $\mathrm{X}$}

As análises de determinação de cristalinidade dos filmes foram realizadas no Instituto de Física de São Carlos da Universidade de São Paulo no Laboratório de RaiosX do Grupo de Cristalografia. Foi utilizado um X-ray diffratometer RU200B (Rigaku Rotaflex), com ânodo de $\mathrm{Cu}$, operando a temperatura ambiente com $40 \mathrm{kV}$ e corrente de $80 \mathrm{~mA}$. As amostras foram cortadas em retângulos de aproximadamente $7 \times 12 \mathrm{~mm}^{2}$ e e analisadas à velocidade de 2Ө/minuto (BERGO; SOBRAL, 2007).

\subsubsection{Espectroscopia de infravermelho com transformada de Fourier (FTIR)}

Para as análises de FTIR, os filmes foram acondicionados por sete dias em dessecadores contendo sílica-gel. Após o período de acondicionamento, as amostras foram colocadas de forma sobreposta sob o sensor do espectrômetro (Spectrum One Perkin Elmer). Foram realizadas 16 varreduras na faixa espectral de $400 \mathrm{a} 4000 \mathrm{~cm}^{-1} \mathrm{com}$ resolução de $2 \mathrm{~cm}^{-1}$. Os dados foram coletados e tratados com o software Spectrum One, (Spectrum One, versão 5.3) (BERGO; SOBRAL, 2007; VICENTINI et al., 2005).

\subsubsection{Permeabilidade ao vapor de água (PVA)}

A determinação da permeabilidade ao vapor de água dos filmes foi realizada por gravimetria (ASTM E96-96M, 2010a), com gradiente de umidade relativa igual à $100 \%$. Utilizaram-se amostras circulares dos filmes, que foram fixadas em células com um anel perfurado (área exposta $31,17 \mathrm{~cm}^{2}$ ) contendo sílica-gel (Figura 7). 
Figura 7: Sistema célula+filme+sílica-gel utilizado nas determinações de permeabilidade ao vapor de água.

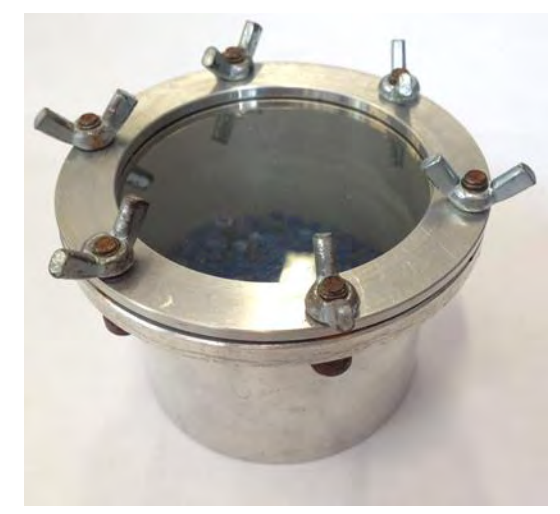

Fonte: Própria autoria

O sistema foi acondicionado em um dessecador contendo água destilada, e pesado diariamente durante 6 dias em uma balança semi-analítica (Marte AS2000). A permeabilidade ao vapor de água foi calculada utilizando-se a equação 5 e o resultado expresso em g.mm/ $/ \mathrm{m}^{2} . \mathrm{h} . \mathrm{kPa}$.

$$
\operatorname{PVA}\left(\mathrm{g} \cdot \mathrm{mm} / \mathrm{h} \cdot \mathrm{m}^{2} \cdot \mathrm{kPa}\right)=\frac{\mathrm{G} \cdot \mathrm{x}}{\mathrm{t} \cdot A_{e} \cdot\left(\mathrm{P}_{1}-\mathrm{P}_{2}\right)}
$$

Onde:

$\mathrm{x}$ : espessura média dos filmes $(\mathrm{mm})$;

$\mathrm{A}_{\mathrm{e}}$ : área exposta $\left(\mathrm{m}^{2}\right)$;

$\mathrm{P}_{1}$ : pressão de vapor da água da água pura $\left(2,642 \mathrm{kPa}\right.$, à $\left.25^{\circ} \mathrm{C}\right)$;

$\mathrm{P}_{2}$ : pressão de vapor da sílica-gel $(0 \mathrm{kPa})$

$\mathrm{G} / \mathrm{t}(\mathrm{g} / \mathrm{h})$ : coeficiente angular da regressão linear da reta de ganho de massa do sistema versus tempo.

\subsubsection{Brilho}

O brilho dos filmes foi medido utilizando-se um glossímetro Rhopoint 20/60 (Rhopoint-NOVO-GLOSS Lite 20/60 ${ }^{\circ}$ STATISTICAL), realizando-se 10 medidas 
aleatórias, no ângulo de $60^{\circ}$. As medidas foram realizadas em ambos os lados dos filmes, ou seja, na superfície em de secagem e na superfície em contato com a placa (VILLALOBOS et al., 2005).

\subsubsection{Determinação do ângulo de contato}

As medidas do ângulo de contato $(\Theta)$ foram realizadas utilizando-se um tensiômetro G1 Kruss (Kruss, GmgH, Alemanha) com auxílio de um software de análise de imagem (Drom Shape Analysis, Kruss GmgH, Alemanha). As medidas foram realizadas depositando-se uma gota de água deionizada $(\sim 1 \mu \mathrm{L})$ na superfície das amostras de filme $\left(50 \times 15 \mathrm{~mm}^{2}\right)$ com auxílio de uma seringa de precisão. A imagem da gota foi fotografada com uma câmera digital durante 30s. Foram realizadas 7 medidas para cada amostra de ambos lados (superfície em contato com a placa e em contato com o ar).

O ângulo de contato consiste no ângulo formado entre a superfície do sólido e uma tangente que passa pela superfície da gota encontrando à superfície ar-líquido-sólido (ZISMAN, 1964) (Figura 8).

Figura 8: Ângulo de contato entre a gota e a superfície do sólido

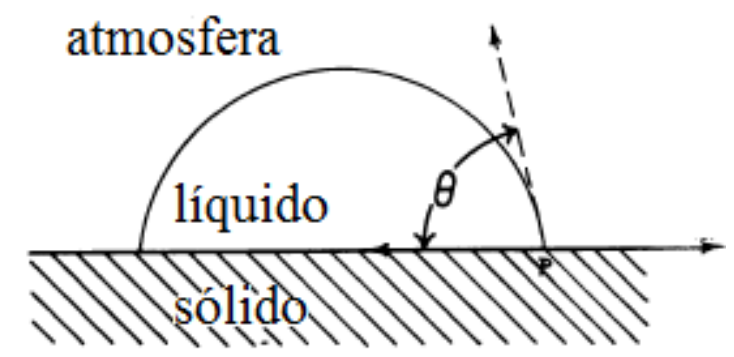

Fonte: ZISMAN, W.A. Relation of the equilibrium contact angle to liquid and solid constitution. Advances in Chemistry Series, Washington, USA, v.43 p. 1-51, 1964.

A partir do valor do ângulo de contato de uma superfície é possível determinar o grau de hidrofobicidade ou hidrofilicidade de um sólido, sendo que, valores elevados de ângulo implicam em superfícies hidrofóbicas e valores baixos, por consequência, implicam em superfícies hidrofílicas. Em geral, adota-se a definição estabelecida por Vogler (1998), onde para $\Theta>65^{\circ}$, considera-se o material hidrofóbico e para $\Theta<65^{\circ}$, 
considera-se o material hidrofílico (KARBOWIAK; DEBEAUFORT; VOILLEY, 2006; VOGLER, 1998).

\subsubsection{Microscopia eletrônica de varredura (MEV)}

A captura de imagens por microscopia eletrônica de varredura dos filmes foi realizada nas superfícies de secagem e em contato com a placa. As amostras também foram criofraturadas, em nitrogênio líquido, para observação da estrutura interna. A análise de microscopia eletrônica de varredura foi realizada em um microscópio eletrônico de varredura microscópio MEV Hitachi, TM3000 (Tokyo, Japão) com feixe a 5 e a $15 \mathrm{kV}$

\subsubsection{Propriedades de barreira à luz (UV/Visível)}

As propriedades de barreira a luz visível e ultravioleta foram determinadas utilizando-se um espectrofotômetro UV/Visível (Lambda 35, Perkin Elmer) com comprimento de onda variando de 200 a $800 \mathrm{~nm}$. A resposta obtida foi a variação da transmitância dos filmes. Os filmes foram cortados em tiras de $10 \mathrm{~cm}$ de comprimento por 1,0 cm de largura, e colocados no lugar da cubeta de forma que o feixe de luz do aparelho passasse através do filme. Estas análises foram realizadas em triplicata (BITENCOURT et al., 2014; FANG et al., 2002).

\subsubsection{Atividade antioxidante dos filmes}

A atividade antioxidante dos filmes foi medida utilizando-se o método de ABTS com algumas adaptações (RE et al., 1999). O reagente ABTS foi produzido por oxidação do persulfato de potássio, assim como o reagente utilizado para as análises dos extratos de boldo-do-Chile (ver tópico 4.4.4). As amostras de filmes foram cortadas em quadrados de $1 \mathrm{~cm}$ de lado, e pesadas $( \pm 1,0 \mathrm{~g}$ de filme) em $50 \mathrm{~mL}$ de água destilada (BITENCOURT et al., 2014; MORADI et al., 2012). As amostras foram solubilizadas em banho termostático à $55^{\circ} \mathrm{C}$ por 10 minutos. Em tubos de ensaio, adicionaram-se $2,949 \mathrm{~mL}$ de regente ABTS à uma alíquota de $60 \mu \mathrm{L}$ da amostra de filme solubilizada. Os tubos de 
ensaio foram mantidos à $37^{\circ} \mathrm{C}$ por 10 minutos e em seguida, as amostras foram centrifugadas utilizando-se uma centrífuga refrigerada (Thermoiec, Centragp8r, EUA) à 3000rpm por 5 minutos. Então procedeu-se a leitura das absorbâncias à $734 \mathrm{~nm}$, em espectrofotômetro UV/Visível (Lambda 35, Perkin Elmer). A inibição do radical ABTS foi a resposta obtida para mesurar a atividade antioxidante dos filmes, sendo calculada com a equação 6 (BITENCOURT et al., 2014; GUTIÉRREZ et al., 2012; MORADI et al., 2012).

$$
\text { Inibição } A B T S(\%)=\left(\frac{A B S_{\text {ABTSinicial }}-A B S_{A B T S f i l m e}}{A B S_{A B T S \text { inicial }}}\right) \times 100
$$

Onde:

$\mathrm{ABS}_{\mathrm{ABTSinicial}}$ : Absorbância inicial do reagente $\mathrm{ABTS}$ à $734 \mathrm{~nm}$

$\mathrm{ABS}_{\mathrm{ABTSfilme}}$ : Absorbância das amostras de filmes solubilizadas

\subsection{Análises estatísticas}

De maneira geral, os dados foram submetidos a análises estatísticas de ANOVA e teste de Tukey, em "two-way" para verificar diferenças significativas entre as médias, utilizando-se o programa SAS versão 9.1 (MAKISHI et al., 2013). 


\section{Resultados e Discussão}

\subsection{Teor de aminoácidos da gelatina e do colágeno}

O teor de aminoácidos das macromoléculas envolvidas nesta tese foi determinado a fim de verificar a disponibilidade de aminoácidos possíveis de interagir com os compostos fenólicos contidos no extrato de boldo-do-Chile. Do ponto de vista químico da interação proteína- composto fenólico, esta pode ocorrer de diferentes maneiras, sendo as principais: ligação de hidrogênio, ligação iônica, interações hidrofóbicas e aromáticas. Além das ligações já mencionadas, as mais interessantes são as ligações covalentes, uma vez que estas são irreversíveis e influenciar as propriedades (químicas) de ambas as substâncias envolvidas na reação (ROHN, 2014).

A interação dos aminoácidos da gelatina e do colágeno com os compostos fenólicos se daria por meio de ligações covalentes, entre estes e os grupos hidroxilas e anéis benzênicos, que seriam capazes de estabilizar a cadeia polipeptídica incrementando algumas propriedades (LEE, 2004; MARQUIÉ et al., 1995). Segundo Marquié et al. (1995) e Carvalho e Grosso (2004) os aminoácidos mais susceptíveis à formação de ligações covalentes são: arginina, histidina e lisina.

Os resultados obtidos tanto para a gelatina, como para o colágeno, (Tabela 4) foram bastante semelhantes, havendo diferença significativa $(p<0,05)$ somente para a isoleucina que foi levemente superior no colágeno, para a metionina que teve um maior valor na gelatina e para a histidina que não foi identificada no colágeno. Os aminoácidos com teor majoritário foram a glicina, a prolina e a hidroxiprolina, que representam juntos 47,9 e 48,6\% na gelatina e no colágeno, respectivamente. Esses aminoácidos formam o triplete que compõe a base da estrutura tanto da gelatina como do colágeno (ARVANITOYANNIS, 2002; CONCA, 2002). 
Tabela 4: Teor de aminoácidos da gelatina e do colágeno utilizados como macromoléculas neste estudo

\begin{tabular}{|c|c|c|}
\hline \multirow{2}{*}{ Aminoácidos } & Gelatina & Colágeno \\
\hline & \multicolumn{2}{|c|}{ Teor (g/100g de proteínas) } \\
\hline Alanina & $8,9 \pm 0,0^{\mathrm{a}}$ & $9,0 \pm 0,2^{\mathrm{a}}$ \\
\hline Arginina & $9,6 \pm 0,0^{\mathrm{a}}$ & $9,6 \pm 0,2^{\mathrm{a}}$ \\
\hline Ácido aspártico & $4,9 \pm 0,2^{\mathrm{a}}$ & $5,0 \pm 0,1^{\mathrm{a}}$ \\
\hline Glicina & $23,4 \pm 0,0^{\mathrm{a}}$ & $23,8 \pm 0,1^{\mathrm{a}}$ \\
\hline Isoleucina & $1,1 \pm 0,0^{\mathrm{b}}$ & $1,4 \pm 0,1^{\mathrm{a}}$ \\
\hline Leucina & $2,8 \pm 0,0^{\mathrm{a}}$ & $2,9 \pm 0,0^{\mathrm{a}}$ \\
\hline Ácido glutâmico & $9,3 \pm 0,0^{\mathrm{a}}$ & $9,4 \pm 0,0^{\mathrm{a}}$ \\
\hline Lisina & $4,7 \pm 0,1^{\mathrm{a}}$ & $4,6 \pm 0,1^{\mathrm{a}}$ \\
\hline Metionina & $0,4 \pm 0,1^{\mathrm{a}}$ & $0,1 \pm 0,1^{\mathrm{b}}$ \\
\hline Fenilalanina & $1,8 \pm 0,0^{\mathrm{a}}$ & $1,7 \pm 0,0^{\mathrm{a}}$ \\
\hline Tirosina & $0,6 \pm 0,0^{\mathrm{a}}$ & $0,6 \pm 0,0^{\mathrm{a}}$ \\
\hline Treonina & $1,6 \pm 0,0^{\mathrm{a}}$ & $1,7 \pm 0,0^{\mathrm{a}}$ \\
\hline Prolina & $13,7 \pm 0,1^{\mathrm{a}}$ & $13,7 \pm 0,0^{\mathrm{a}}$ \\
\hline Hidroxiprolina & $10,8 \pm 0,0^{\mathrm{a}}$ & $11,1 \pm 0,2^{\mathrm{a}}$ \\
\hline Valina & $2,2 \pm 0,0^{\mathrm{a}}$ & $2,0 \pm 0,1^{\mathrm{a}}$ \\
\hline Histidina & $0,9 \pm 0,0$ & ND \\
\hline Serina & $3,3 \pm 0,0^{\mathrm{a}}$ & $3,3 \pm 0,1^{\mathrm{a}}$ \\
\hline
\end{tabular}

Fonte: Própria autoria

a,b letras minúsculas diferentes na mesma linha indicam diferença significativa para o mesmo parâmetro.

O resultado obtido para o perfil de aminoácidos da gelatina foi semelhante ao de Carvalho e Grosso (2004), com exceção para o valor da glicina que foi de 32 (g/100g de gelatina). Com relação ao perfil de aminoácidos para o colágeno Wolf, Sobral e Telis (2009) estudaram colágeno de origem bovina e o teor de aminoácidos obtidos por esses autores foi bastante semelhante ao determinado neste estudo. Chaudry et al. (1997) determinaram os teores de glicina, prolina e hidroxiprolina e encontrou 26,6, 14,4 e 12,8 $\mathrm{g} / 100 \mathrm{~g}$ de proteínas, respectivamente. Esses valores são bastante semelhantes aos encontrados neste estudo, entretanto, sabe-se que a origem do colágeno pode influenciar no teor dos aminoácidos presente na amostra (CONCA, 2002). 


\subsection{Caracterizações dos extratos de boldo-do-Chile}

\subsubsection{Teor de sólidos solúveis ( $\left({ }^{\circ} \mathrm{Brix}\right), \mathrm{pH}$ e cor}

Na Tabela 5 encontram-se os resultados obtidos para o teor de sólidos solúveis, onde se pode observar um efeito estatístico significativo $(\mathrm{p}<0,05)$ para a temperatura de extração. O teor de sólidos solúveis, expresso em ${ }^{\circ}$ Brix, aumentou com o aumento da temperatura de extração, os valores encontrados ficaram entre 3,1 e $4,3^{\circ}$ Brix.

Tabela 5: Efeito da temperatura de extração sobre o teor de sólidos solúveis ( ${ }^{\circ} \mathrm{Brix}$ ) e o pH do extrato de boldo-do-Chile (Peumus boldus).

\begin{tabular}{ccc}
\hline Temperatura de extração $\left({ }^{\circ} \mathbf{C}\right)$ & OBrix & $\mathbf{p H}$ \\
\hline $\mathbf{3 0}$ & $3,1 \pm 0,2^{\mathrm{c}}$ & $5,1 \pm 0,1^{\mathrm{a}}$ \\
$\mathbf{4 5}$ & $3,4 \pm 0,1^{\mathrm{bc}}$ & $5,1 \pm 0,1^{\mathrm{a}}$ \\
$\mathbf{6 0}$ & $3,6 \pm 0,1^{\mathrm{b}}$ & $5,0 \pm 0,0^{\mathrm{a}}$ \\
$\mathbf{9 0}$ & $4,3 \pm 0,2^{\mathrm{a}}$ & $5,0 \pm 0,0^{\mathrm{a}}$ \\
\hline
\end{tabular}

Fonte: Própria autoria

a,b letras minúsculas diferentes na mesma coluna indicam diferença significativa para o mesmo parâmetro.

Por outro lado, a temperatura não influenciou $(\mathrm{p}>0,05)$ o $\mathrm{pH}$ dos extratos, que

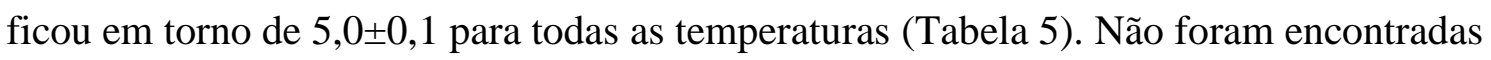
informações na literatura sobre o teor de sólidos solúveis e $\mathrm{pH}$ de extratos produzidos a partir de plantas.

Com relação aos parâmetros de cor L*, $\mathrm{a}^{*}$ e $\mathrm{b}^{*}$ (Tabela 6) observou-se que a variação da temperatura apresentou efeito sobre todos os parâmetros. Os valores para a luminosidade ( $\mathrm{L}^{*}$ ) ficaram entre 26,9 e 36,9 . Com relação ao parâmetro a*, que está relacionado a variação entre vermelho (+) e verde (-), observou-se que embora tenha havido diferença estatística significativa $(\mathrm{p}<0,05)$, os resultados foram muito próximos ficando ao redor de 25 (Tabela 6), indicando que coloração do extrato tende mais para o vermelho. O mesmo comportamento pode ser observado para o parâmetro b*, que é a variação do amarelo (+) ao azul (-), cujas respostas variaram de 39 a 57, o que indica a presença de tons amarelos no extrato. Os parâmetros determinados representam, no seu conjunto, uma coloração marrom avermelhada (Figura 9). 
Tabela 6: Efeito da temperatura de extração sobre os parâmetros de cor ( $L^{*}, a^{*}$ e b*) do extrato de boldo-do-Chile (Peumus boldus).

\begin{tabular}{cccc}
\hline $\begin{array}{c}\text { Temperatura de } \\
\text { extração }\left({ }^{\mathbf{0}} \mathbf{C}\right)\end{array}$ & $\mathbf{L}^{*}$ & $\mathbf{a}^{*}$ & $\mathbf{b}^{*}$ \\
\hline $\mathbf{3 0}$ & $36,9 \pm 0,1^{\mathrm{a}}$ & $24,0 \pm 1,2^{\mathrm{bc}}$ & $56,6 \pm 5,1^{\mathrm{a}}$ \\
$\mathbf{4 5}$ & $26,9 \pm 2,4^{\mathrm{c}}$ & $23,6 \pm 2,0^{\mathrm{c}}$ & $38,9 \pm 6,4^{\mathrm{b}}$ \\
$\mathbf{6 0}$ & $28,8 \pm 1,5^{\mathrm{bc}}$ & $27,4 \pm 0,5^{\mathrm{ab}}$ & $45,9 \pm 2,7^{\mathrm{ab}}$ \\
$\mathbf{9 0}$ & $33,0 \pm 3,6^{\mathrm{ab}}$ & $27,6 \pm 1,2^{\mathrm{a}}$ & $54,2 \pm 6,6^{\mathrm{a}}$ \\
\hline
\end{tabular}

Fonte: Própria autoria

a,b letras minúsculas diferentes na mesma coluna indicam diferença significativa para o mesmo parâmetro.

Figura 9: Amostra de extrato aquoso de boldo-do-Chile produzido à $45^{\circ} \mathrm{C}$

Fonte: Própria autoria

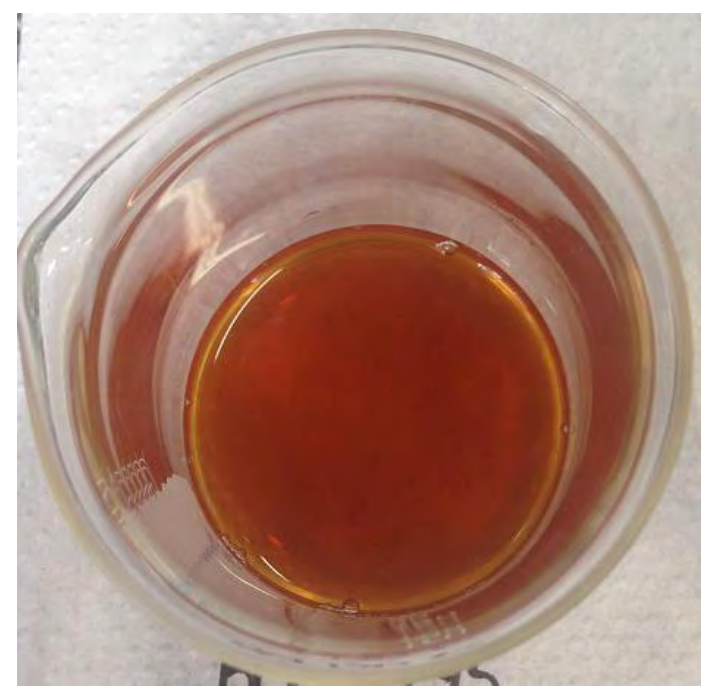

De maneira geral os extratos produzidos apresentaram a mesma coloração, amostras das tonalidades dos extratos produzidos foram geradas com o Programa EasyRGB (Figura 10) (http://www.easyrgb.com/index.php?X=CALC). 
Figura 10: Cores dos extratos de boldo-do-Chile produzidas utilizando os resultados da Tabela 6 no Programa EasyRGB.
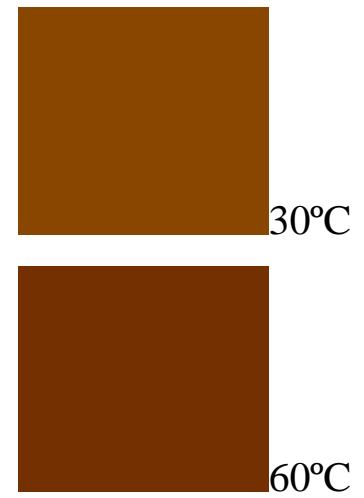
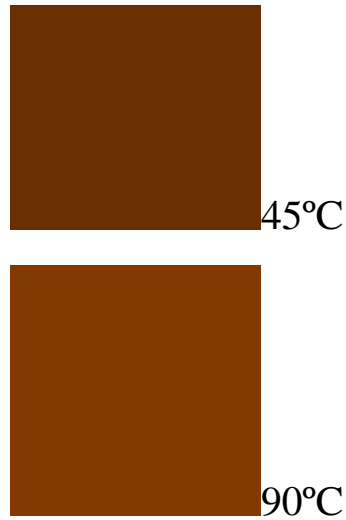

Fonte:EASYRGB. Disponível em: <http://www.easyrgb.com/index.php?X=CALC>. Acesso em: 03 de outubro de 2015.

\subsubsection{Avaliação do potencial antioxidante (fenólicos totais, DPPH e ABTS)}

Foram analisados os extratos aquosos produzidos nas quatro temperaturas: 30, 45, 60 e $90^{\circ} \mathrm{C}$. As análises realizadas para determinar a atividade antioxidante dos extratos aquosos de boldo-do-Chile confirmaram o potencial antioxidante desses extratos. Além disso, observou-se que houve efeito da temperatura no poder antioxidante dos mesmos.

Para a realização da análise do potencial antioxidante do extrato de boldo-doChile, a partir da atividade sequestrante do radical DPPH, foi necessária uma avaliação prévia acerca do tempo de estabilização do extrato frente ao radical DPPH. Esse ensaio seguiu a metodologia descrita no item 4.4.3, sendo que a amostra do extrato foi colocada em contato com o reagente DPPH e a absorbância foi medida a cada 5 minutos até a estabilização da medição. De acordo com Prado (2009), o tempo de estabilização deve ser avaliado para cada erva ou planta não para cada extrato produzido, uma vez que a concentração e o tipo de extração não exercem influência sobre o tempo de reação com o radical.

Para o extrato de boldo-do-Chile produzido nesse trabalho, percebeu-se que a amostra atingiu um patamar com 10 minutos (Figura 11). No entanto, para assegurar tempo suficiente para que o extrato reagisse com o radical, escolheu-se aumentar o tempo de estabilização para 25 minutos. 
Figura 11: Curva do tempo de estabilização do extrato de boldo-do-Chile para a análise de DPPH.

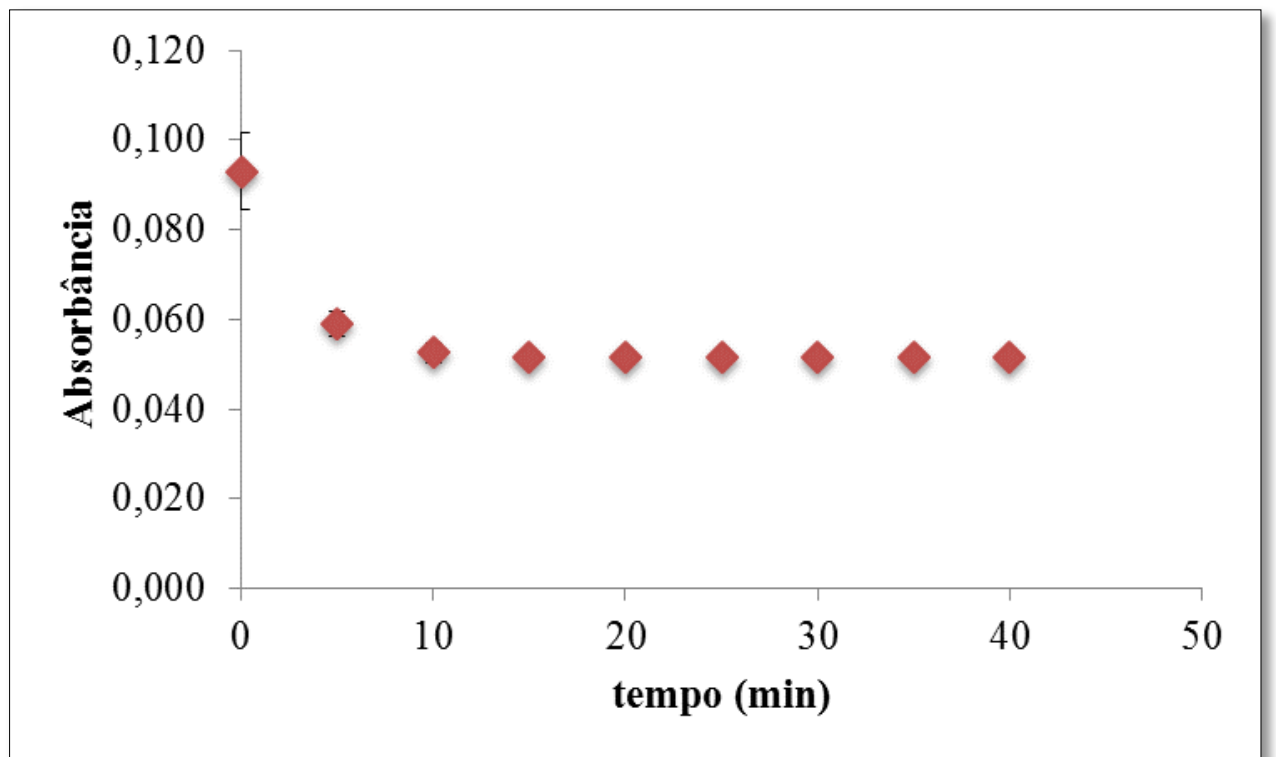

Fonte: Própria autoria

Os resultados obtidos paras as análises antioxidantes (fenólicos totais, DPPH e ABTS) encontram-se na Tabela 7. Para a análise de DPPH, o resultado obtido foi expresso pelo índice EC 50, que trata da concentração mínima de extrato necessária à inibição do radical DPPH. Observou-se que não houve diferença estatística significativa $(p>0,05)$ para as temperaturas 45,60 e $90^{\circ} \mathrm{C}$, com valor médio de $23,9 \mathrm{~mL}$ de extrato/L de etanol. $\mathrm{O}$ extrato produzido à $30^{\circ} \mathrm{C}$ apresentou o maior valor de concentração $(31,4 \mathrm{~mL}$ de extrato/L de etanol). Dessa forma, os extratos produzidos de 45 à $90^{\circ} \mathrm{C}$ apresentaram maior potencial antioxidante perante ao radical DPPH.

Com relação ao teor de fenólicos totais (Tabela 7), observou-se que extratos de boldo-do-Chile produzidos nas temperaturas de 45,60 e $90^{\circ} \mathrm{C}$ apresentaram maior teor de fenólicos totais do que o produzido à $30^{\circ} \mathrm{C}(\mathrm{p}<0,05)$. Entretanto, não houve diferença estatística significativa ( $p>0,05)$ para a concentração de fenólicos para as temperaturas de 45,60 e $90^{\circ} \mathrm{C}$. 
Tabela 7: Resultados obtidos para a avaliação do potencial antioxidante dos extratos de boldo-do-Chile produzidos em diferentes temperaturas.

\begin{tabular}{|c|c|c|c|}
\hline Temperatura de extração $\left({ }^{\circ} \mathrm{C}\right)$ & $\begin{array}{c}\text { DPPH } \\
\text { EC 50(mL de } \\
\text { extrato/L de } \\
\text { etanol) }\end{array}$ & $\begin{array}{c}\text { Fenólicos } \\
\text { Totais } \\
\text { (mg de ácido } \\
\text { gálico/mL de } \\
\text { extrato) }\end{array}$ & $\begin{array}{c}\text { ABTS } \\
\text { (mg de } \\
\text { TROLOX/mL } \\
\text { de extrato) }\end{array}$ \\
\hline 30 & $31,4 \pm 4,4^{\mathrm{a}}$ & $2,5 \pm 0,2^{\mathrm{b}}$ & $5,5 \pm 0,2^{\mathrm{b}}$ \\
\hline 45 & $23,7 \pm 1,0^{\mathrm{b}}$ & $3,0 \pm 0,1^{\mathrm{a}}$ & $7,4 \pm 0,2^{\mathrm{a}}$ \\
\hline 60 & $24,3 \pm 2,6^{\mathrm{b}}$ & $3,0 \pm 0,2^{\mathrm{a}}$ & $7,3 \pm 0,2^{\mathrm{a}}$ \\
\hline 90 & $23,8 \pm 1,2^{\mathrm{b}}$ & $2,9 \pm 0,1^{\mathrm{a}}$ & $7,3 \pm 0,3^{\mathrm{a}}$ \\
\hline
\end{tabular}

Fonte: Própria autoria

a,b letras minúsculas diferentes na mesma coluna indicam diferença significativa para o mesmo parâmetro.

Ao medir a atividade antioxidante do extrato de boldo-do-Chile (Peumus boldus) pelo método ABTS (Tabela 7), observou-se o mesmo comportamento que para as demais análises, ou seja, não houve diferença estatística significativa ( $\mathrm{p}>0,05)$ para as temperaturas 45,60 e $90^{\circ} \mathrm{C}$, apresentando um valor médio de 7,3 $\pm 0,1 \mathrm{mg}$ de Trolox equivalente $/ \mathrm{mL}$ de extrato). Já a extração realizada à $30^{\circ} \mathrm{C}$ produziu extratos com menor $(\mathrm{p}<0,05)$ poder antioxidante frente ao radical ABTS $(5,5 \mathrm{mg}$ de Trolox equivalente/mL de extrato).

Falé et al. (2012) produziram extratos de boldo-do-Chile utilizando $10 \mathrm{~g}$ de folhas frescas em $300 \mathrm{~mL}$ de água destilada à $100^{\circ} \mathrm{C}$, o líquido recolhido da filtração foi liofilizado e sua atividade antioxidante foi determinada pelo método DPPH. O extrato produzido apresentou potencial antioxidante superior (EC50 igual à $18,7 \mathrm{~mL}$ de extrato/L de etanol) aos extratos produzidos neste estudo. Como os autores trabalharam com o extrato liofilizado, os compostos antioxidantes ficam mais concentrados o que justifica a maior atividade antioxidante encontrada.

De maneira geral, os resultados do teor de fenólicos totais obtidos neste estudo foram superiores aos encontrados na literatura. Muñoz-Velázquez et al. (2012), prepararam de infusões de boldo-do-Chile (Peumus boldus) preparadas com $1 \mathrm{~g}$ de folhas em $200 \mathrm{~mL}$ de água destilada à $100^{\circ} \mathrm{C}$ por 10 minutos. O teor de fenólicos totais foi de $312,7 \pm 4,4 \mu \mathrm{g}$ de ácido gálico/mL de extrato $(0,3127 \pm 0,0044 \mathrm{mg}$ de ácido gálico/mL de 
extrato). Vaquero et al. (2010) também estudaram o comportamento de infusões de boldodo-Chile preparadas com $2 \mathrm{~g}$ de folhas e $250 \mathrm{~mL}$ de água destilada à $90^{\circ} \mathrm{C}$ por 10 minutos, e com relação ao teor de fenólicos totais esses autores encontraram 409mg de ácido gálico/L de infusão $(0,409 \mathrm{mg}$ de ácido gálico/mL de infusão). Ainda com infusões de boldo-do-Chile, Alarcón et al. (2008) obtiveram como resultado $376 \mathrm{mg}$ de ácido gálico/litro de infusão (0,376mg de ácido gálico/ml de infusão), sendo estas preparadas com $2 \mathrm{~g}$ de folhas e $150 \mathrm{~mL}$ de água destilada à $95-100^{\circ} \mathrm{C}$ por 5 minutos.

Para a análise de redução do radical ABTS, os resultados obtidos neste estudo foram igualmente superiores aos encontrados na literatura. Muñoz-Velázquez et al. (2012) nas condições de extração já citadas, obtiveram para suas infusões de boldo-doChile uma atividade antioxidante igual a $3,61 \pm 0,1 \mu \mathrm{mol}$ de TROLOX $/ \mathrm{mL}$ de extrato $(0,904 \mathrm{mg}$ de TROLOX/mL de extrato), sendo bastante inferior aos resultados obtidos nesta tese.

Os extratos de boldo-do-Chile produzidos neste estudo apresentaram, de forma geral, propriedades antioxidantes superiores aos resultados encontrados na literatura. Isso pode ser justificado pelas diferentes condições de extração (tempo e temperatura), e pela diferença na relação planta:água. Ressalta-se que extratos estudados nesta tese foram produzidos com $5 \mathrm{~g}$ de pó de boldo-do-Chile em $50 \mathrm{~mL}$ de água destilada por 30 minutos, independentemente da temperatura de extração. 


\subsubsection{Análise microbiológica: Teste de Sensibilidade pelo Método de Poço Difusão}

A atividade antimicrobiana dos extratos de boldo-do-Chile (Peumus boldus) foi avaliada pelo método de poço de difusão utilizando-se quatro cepas das seguintes bactérias: Escherichia coli, ATCC 25922; Pseudomonas aeruginosa, ATCC 15442; Salmonella spp, ATCC 13076 e Staphylococcus aureus, ATCC 25923. Para a realização desta análise foram escolhidos os extratos com melhor atividade antioxidante, ou seja, os extratos produzidos nas temperaturas de 45,60 e $90^{\circ} \mathrm{C}$. Observou-se que estes extratos não apresentaram atividade antimicrobiana para essas bactérias, ou seja, não foi detectado halo de inibição para nenhuma das diluições realizadas. Pôde-se observar o surgimento do halo de inibição somente ao redor do poço central que continha o antibiótico controle (clorafenicol) (Figura 12, 13 e 14). Não foram encontradas na literatura informações sobre o poder antimicrobianos de extratos de boldo-do-Chile.

Figura 12: Imagens das análises microbiológicas para o extrato de boldo-do-Chile produzido à $45^{\circ} \mathrm{C}$ (a) Escherichia coli, (b) Salmonella spp, (c) Staphylococcus aureus (d) Pseudomonas aeruginosa.

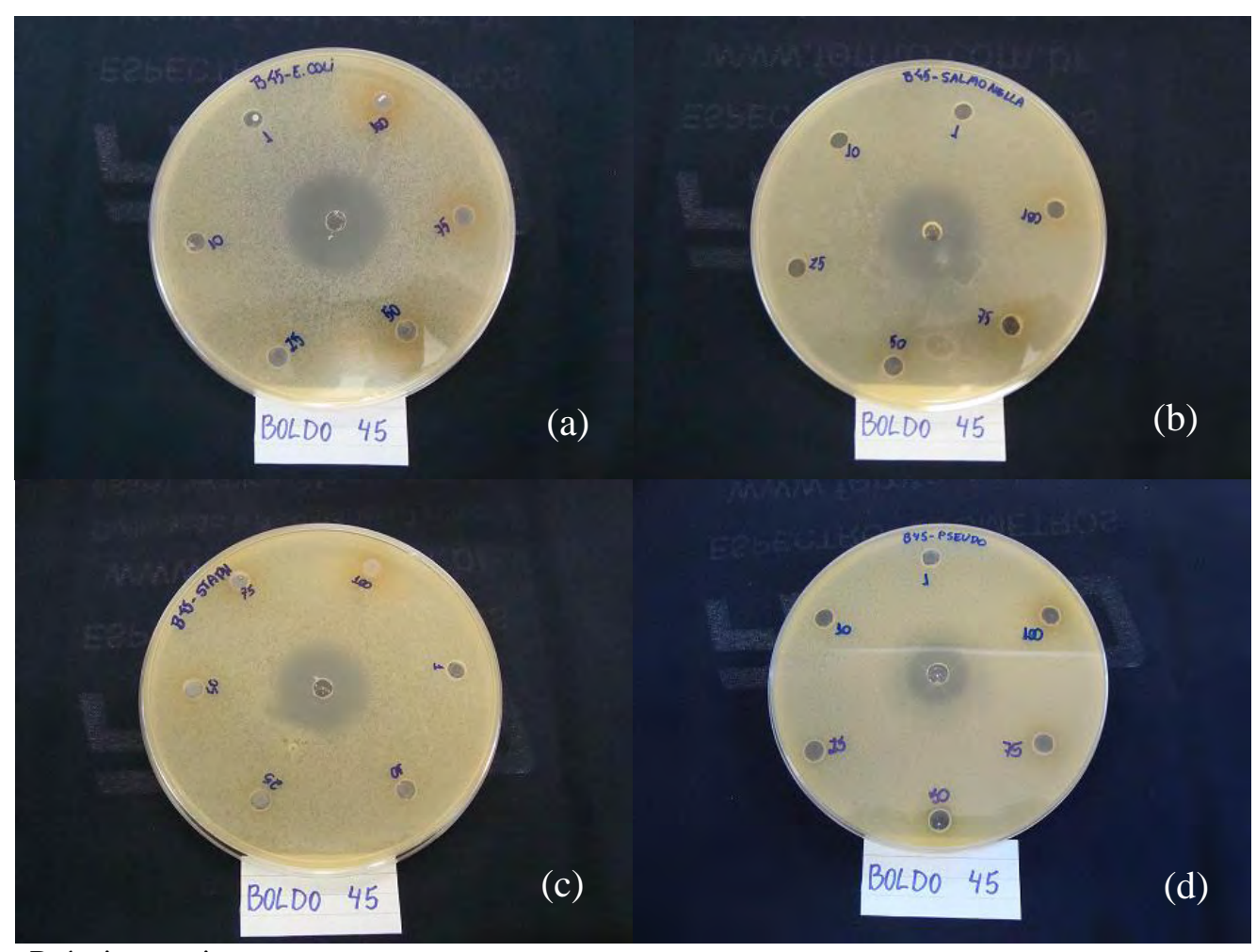

Fonte: Própria autoria 
Figura 13: Imagens das análises microbiológicas para o extrato de boldo-do-Chile produzido à $60^{\circ} \mathrm{C}$ (a) Escherichia coli, (b) Salmonella spp, (c) Staphylococcus aureus (d) Pseudomonas aeruginosa.

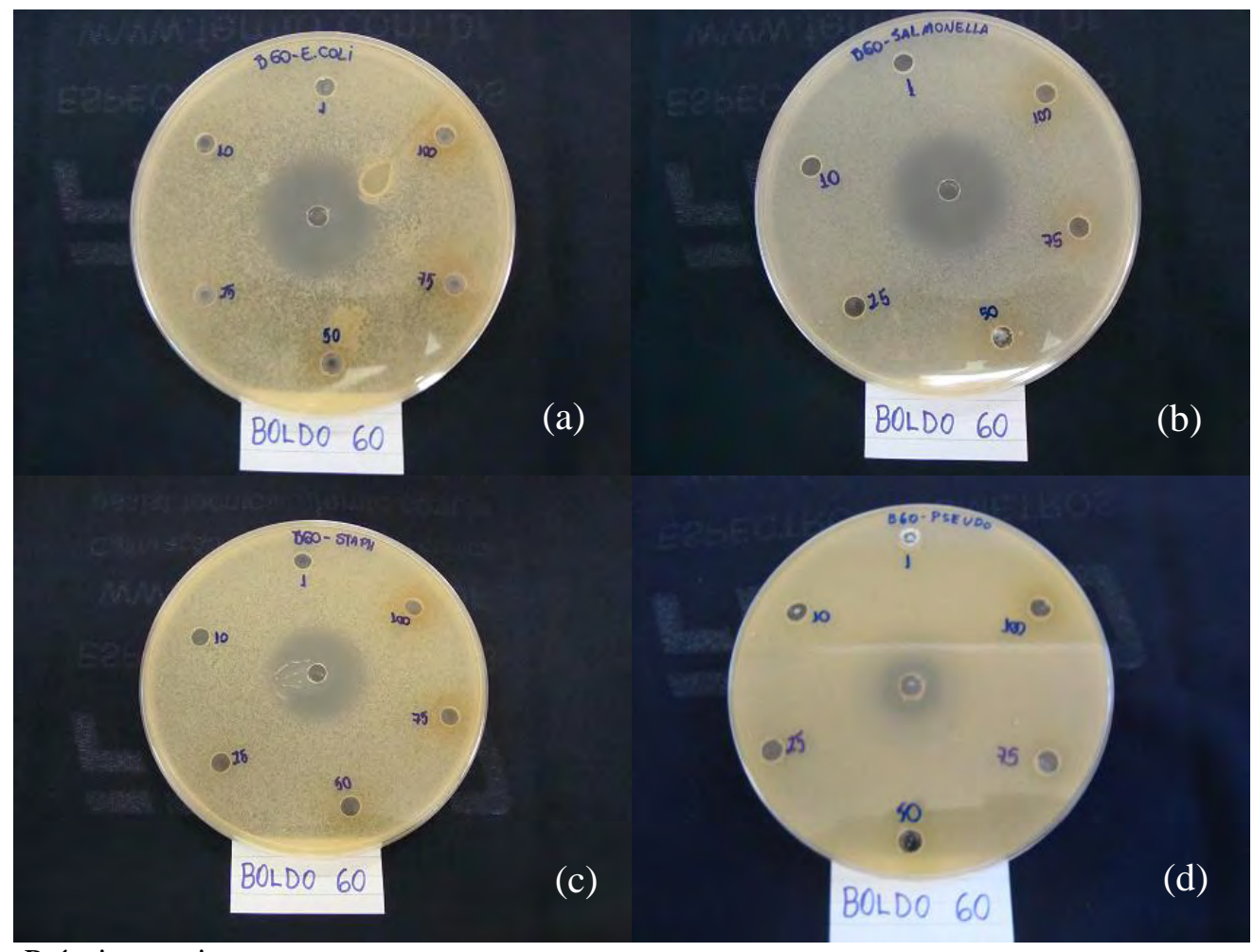

Fonte: Própria autoria 
Figura 14: Imagens das análises microbiológicas para o extrato de boldo-do-Chile produzido à $90^{\circ} \mathrm{C}$ (a) Escherichia coli, (b) Salmonella spp, (c) Staphylococcus aureus (d) Pseudomonas aeruginosa.

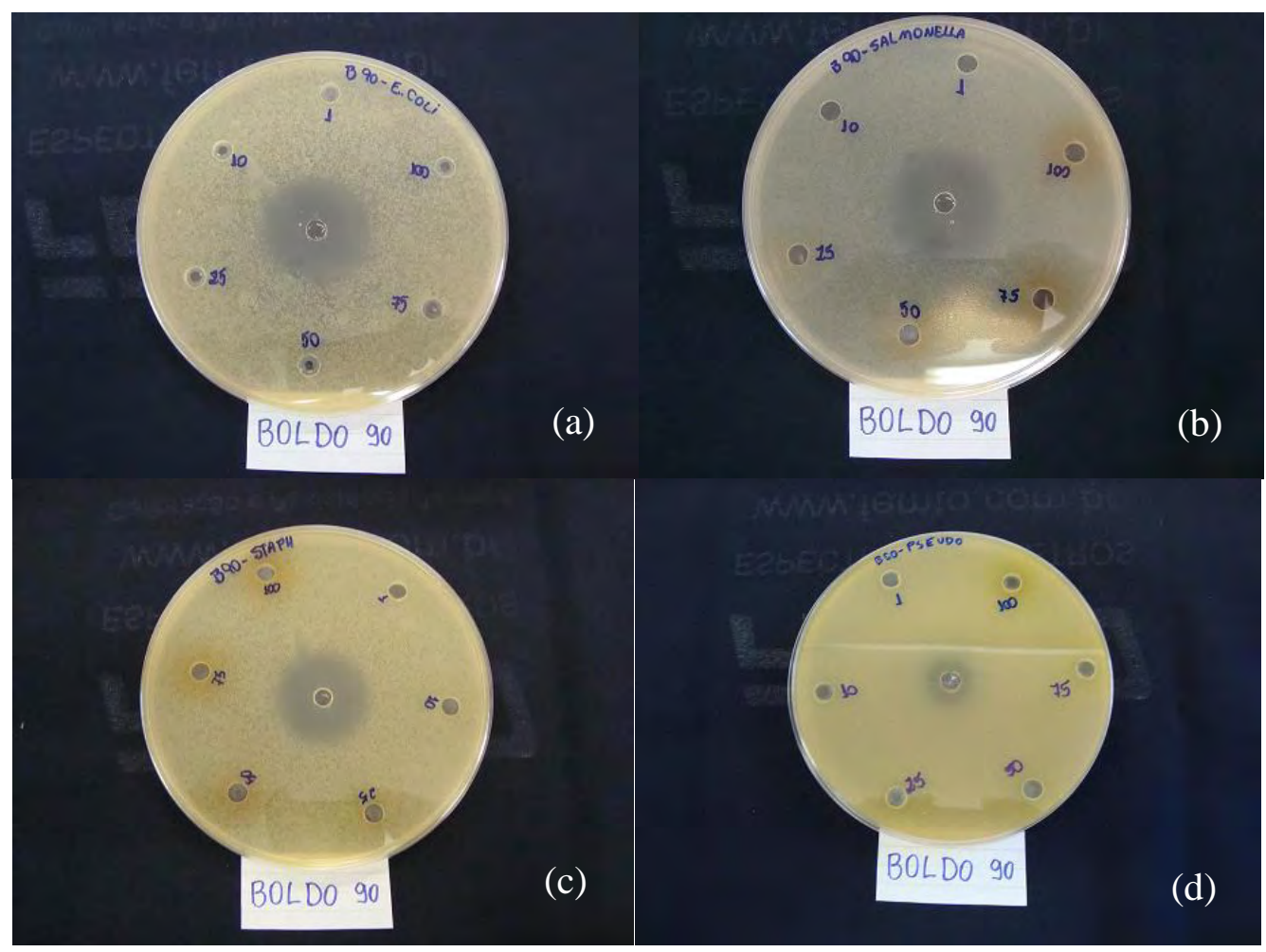

Fonte: Própria autoria

Em função desses resultados das análises microbiológicas dos extratos apresentaram um resultado negativo, optou-se por não realizar as análises antimicrobianas nos filmes de gelatina e colágeno adicionados dos extratos.

\subsubsection{Identificação dos compostos fenólicos por UHPLC-DAD-MS}

Como todos os extratos vegetais, o extrato aquoso de boldo-do-Chile apresentou uma composição muito complexa (Figura 15 e 16). Duas famílias de compostos foram evidenciadas pelas análises cromatográficas UHPLC-DAD-MS: os alcaloides, ionizáveis em modo positivo e os compostos fenólicos, que são mais facilmente detectáveis em modo negativo. Os picos apresentados nas figuras encontram-se identificados nas tabelas Tabela 8 e 9. 
Figura 15: Cromatograma UHPLC-DAD-MS feito em modo electrospray positivo do extrato aquoso do boldo produzido à $30^{\circ} \mathrm{C}$.

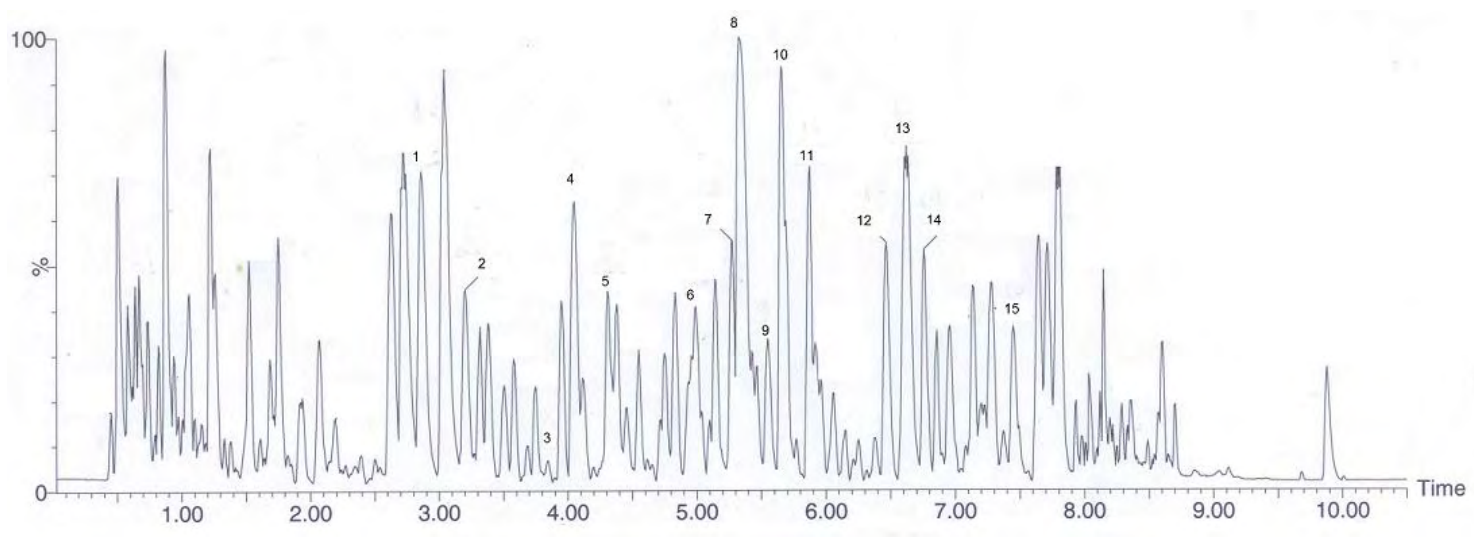

Fonte: Própria autoria

Figura 16: Cromatograma UHPLC-DAD-MS feito em modo electrospray negativo do extrato aquoso do boldo produzido à $30^{\circ} \mathrm{C}$.

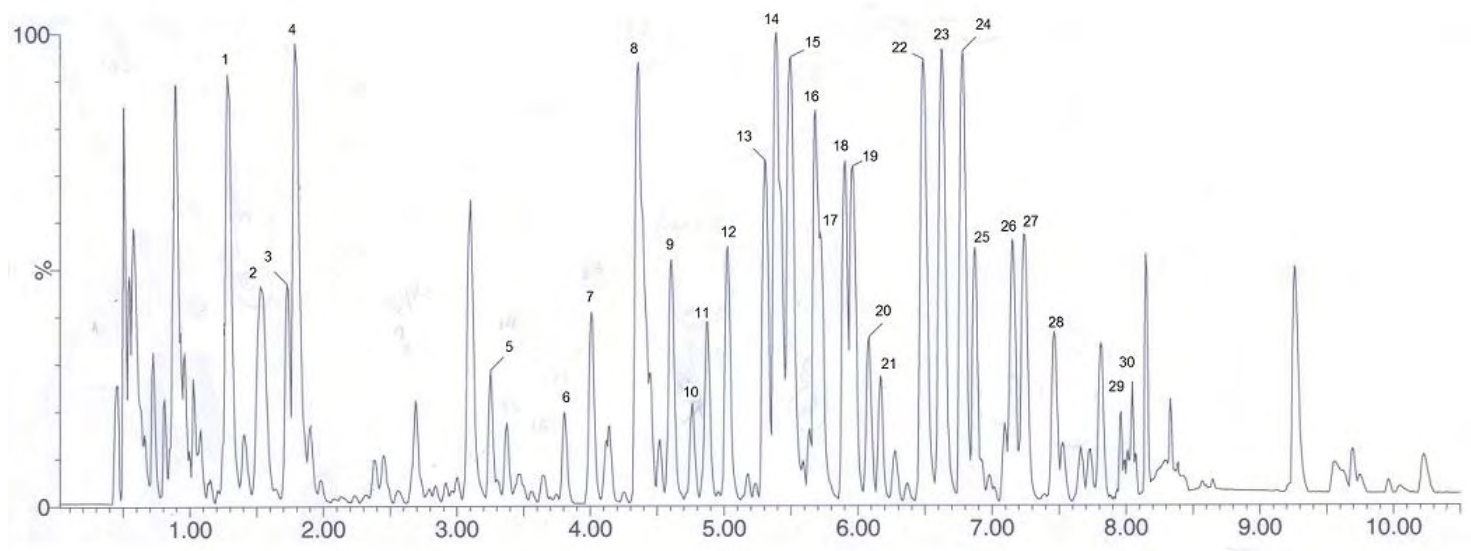

Fonte: Própria autoria

A identificação dos principais compostos foi realizada baseando-se nos espectros UV-Visível dos compostos e seus espectros de massa (em modo positivo ou negativo). As informações obtidas foram comparadas aos dados disponíveis na literatura (FALÉ et al., 2012; SIMIRGIOTIS; SCHMEDA-HIRSCHMANN, 2010; SOTO et al. 2014). Além disso, padrões de alguns compostos foram injetados nas mesmas condições que os extratos e seus espectros obtidos contribuíram para a identificação dos compostos.

Entretanto, para alguns compostos, nenhuma informação foi encontrada. Dessa forma, sua identificação foi realizada por analogia à compostos da mesma família, levando em consideração, a polaridade, o espectro UV e sua fragmentação em 
espectrometria de massa. Além disso, as análises cromatográficas apontaram ainda a existência de isômeros dos compostos adicionados de açúcares (derivados glicosilados).

Com a análise UHPLC-DAD-MS realizada em modo positivo, confirmou-se a presença de 3 alcaloides (boldina, reticulina e n-metilaurotetanina). A partir das informações disponíveis na literatura pode-se sugerir a presença de outros 5 compostos: n-metilcoclaurina, lautotetanina, coclaurina, norglaucina e laudanosina (Tabela 8).

Segundo O’Brien, Carrasco-Pozo e Speisky (2006), estudando sobre as folhas de boldo, os compostos podem ser divididos em aporfinas e benzilisoquinolinas. Dentre as as aporfinas que se destacaram estão: a boldina, norglaucina, n-metilaurotetanina, laurotetatina e outros dos seus derivados (derivados de boldina e norglaucina), e as benzilisoquinolinas: n-metilcoclaurina, coclaurina e laudanosina. Algumas dessas substâncias foram encontradas por Falé et al. (2012), que também trabalharam com extrato aquoso de boldo-do Chile.

Tabela 8: Alcaloides e flavonoides identificados à partir da análise UHPLC-DAD-MS realizada em modo electrospray positivo do extrato aquoso do boldo produzido à $30^{\circ} \mathrm{C}$

\begin{tabular}{|c|c|c|c|c|c|}
\hline Picos & $\begin{array}{c}\mathbf{T}_{\mathbf{R}} \\
(\mathbf{m i n})\end{array}$ & $\lambda \max (\mathrm{nm})$ & $\begin{array}{c}\text { Massa } \\
\text { monoisotópica } \\
(\mathrm{g} / \mathrm{mol})\end{array}$ & Fragmentacão dos ions & Identificação \\
\hline 1 & 2,86 & $201 ; 278$ & 299 & $\mathbf{3 0 0} ; 269 ; 237 ; 194 ; 175 ; 143 ; 107$ & n-methilcoclaurina \\
\hline 2 & 3,20 & 201 & 327 & $\mathbf{3 2 8} ; 297 ; 265 ; 237 ; 233 ; 222 ; 205 ; 177$ & Boldina \\
\hline 3 & 3,82 & 201 & 327 & $\mathbf{3 2 8}, 317 ; 207$ & Laurotetanina \\
\hline 4 & 4,05 & $201 ; 278$ & 329 & 330;299;192;137 & Reticulina \\
\hline $5 *$ & 4,31 & $202 ; 254 ; 353$ & 632 & $\mathbf{6 3 3} ; 487 ; 449 ; 317 ; 303 ; 229 ; 153$ & $\begin{array}{l}\text { derivado de quercetina } \\
\text { (adicionado de } \mathrm{Na} \text { ) }\end{array}$ \\
\hline $6^{*}$ & 4,99 & $201 ; 266 ; 344$ & 604 & $\mathbf{6 0 5} ; 573 ; 453 ; 350 ; 328 ; 247 ; 189$ & $\begin{array}{c}\text { derivado de boldina }+ \text { derivado } \\
\text { de norglaucina }\end{array}$ \\
\hline $7 *$ & 5,28 & $199 ; 265 ; 346$ & 586 & $\mathbf{5 8 7} ; 441 ; 309 ; 287 ; 155$ & derivado kaempferol + $\mathrm{Na}$ \\
\hline 8 & 5,33 & $198 ; 264 ; 347$ & 341 & $\mathbf{3 4 2} ; 311 ; 299 ; 296 ; 279 ; 267 ; 236$ & n-methilaurotetanina \\
\hline 9 & 5,55 & 203 & 285 & $\mathbf{2 8 6} ; 205$ & $\begin{array}{l}\text { coclaurina } \\
\text { derivado de quercetina } \\
\text { (adicionado de } \mathrm{Na} \text { ) }\end{array}$ \\
\hline $10 *$ & 5,65 & $203 ; 253 ; 353$ & 792 & $\mathbf{7 9 3} ; 647 ; 487 ; 331 ; 317 ; 303 ; 153$ & $\begin{array}{c}\text { + derivado de isorhamnetina } \\
\text { (adicionado de } \mathrm{Na}) \\
\text { coeluídos }\end{array}$ \\
\hline $11^{*}$ & 5,88 & $203 ; 253 ; 354$ & 616 & $\mathbf{6 1 7} ; 471 ; 339 ; 317 ; 302 ; 155$ & $\begin{array}{c}\text { derivado de quercetina } \\
\text { (adicionado de } \mathrm{Na})+ \\
\text { derivado de isorhamnetina } \\
\text { (adicionado de } \mathrm{Na} \text { ) } \\
\text { coeluídos }\end{array}$ \\
\hline 12 & 6,47 & $198 ; 263 ; 343$ & 600 & $\begin{array}{c}\mathbf{6 0 1} ; 453 ; 309 ; 287 ; 194 \\
\mathbf{3 4 2} ; 311 ; 296 ; 280\end{array}$ & $\begin{array}{l}\text { derivado de boldina } \\
\text { norglaucina }\end{array}$ \\
\hline $13^{*}$ & 6,62 & $198 ; 264 ; 343$ & 341 & $\mathbf{3 4 2} ; 311 ; 296 ; 280 ; 265$ & $\begin{array}{c}\text { derivado de } \\
\text { n-methilaurotetanina }\end{array}$ \\
\hline $14^{*}$ & 6,76 & $203 ; 253 ; 347$ & 630 & $\mathbf{6 3 1} ; 605 ; 485 ; 393 ; 317 ; 302 ; 153$ & $\begin{array}{l}\text { derivado de isorhamnetina } \\
\text { (adicionado de } \mathrm{Na} \text { ) }\end{array}$ \\
\hline 15 & 7,45 & $210 ; 343$ & 357 & 358; $317 ; 279 ; 189$ & laudanosina \\
\hline
\end{tabular}

Fonte: Própria autoria

* à confirmar 
Em modo negativo, foi possível identificar 35 flavonoides, dos quais 23 puderam ser confirmados (Tabela 9). Foram encontrados flavan-3-ols, a catequina e seus derivados oligoméricos, e também flavonóis, derivados glicosilados de quercetina, kaempferol e de isorhamnetina. Alguns destes compostos também foram identificados em modo positivo. Alguns compostos foram identificados por comparação com dados encontrados na literatura (FALÉ et al., 2012; SIMIRGIOTIS; SCHMEDA-HIRSCHMANN, 2010).

As informações obtidas por UHPLC-MS sobre a composição dos extratos corrobora com os resultados apresentados para as análises antioxidantes (ver tópico 5.2.2), isso porque a presença dos compostos fenólicos evidenciada pelas análises cromatográficas justificam os resultados obtidos para as análises acerca do potencial antioxidante. 
Tabela 9: Flavonoides identificados à partir da análise UHPLC-DAD-MS estabelecidas em modo electrospray em modo negativo do extrato aquoso de boldo produzido à $30^{\circ} \mathrm{C}$.

\begin{tabular}{|c|c|c|c|c|c|}
\hline Picos & $\underset{(\mathrm{min})}{\mathbf{T}_{\mathrm{R}}}$ & $\lambda \max (\mathrm{nm})$ & $\begin{array}{c}\text { Massa } \\
\text { monoisotópica } \\
(\mathrm{g} / \mathrm{mol})\end{array}$ & Fragmentacão dos ions & Identificação \\
\hline 1 & 1,28 & 201 & 578 & $\mathbf{5 7 7 ; 4 0 7 ; 2 8 9 ; 1 6 1 ; 1 2 5}$ & dímero de catequina \\
\hline 2 & 1,53 & $199 ; 278$ & 578 & $\mathbf{5 7 7} ; 407 ; 289 ; 161 ; 125$ & dímero de catequina \\
\hline 3 & 1,73 & $200 ; 278$ & 866 & $\begin{array}{c}\mathbf{8 6 5} ; 739 ; 695 ; 576 ; 407 ; 289 ; 161 ; \\
125\end{array}$ & trímero de catequina \\
\hline 4 & 1,79 & $202 ; 278$ & 290 & $\mathbf{2 9 8} ; 245 ; 203 ; 161 ; 123$ & $\begin{array}{c}\text { catequina } \\
\text { quercetina+ }\end{array}$ \\
\hline 5 & 3,25 & 201 & 742 & $\mathbf{7 4 1 ; 5 9 5 ; 4 4 6 ; 2 9 9 ; 2 7 1 ~}$ & $\begin{array}{l}\text { pentose+hexose+ } \\
\text { ramnose }\end{array}$ \\
\hline 6 & 3,81 & $200 ; 266$ & 726 & $\mathbf{7 2 5} ; 579 ; 431 ; 285$ & $\begin{array}{l}\text { kaempferol }+ \text { pentose }+ \\
\text { hexose }+ \text { rhmanose }\end{array}$ \\
\hline \multirow{2}{*}{7} & 4,01 & $199 ; 265 ; 347$ & 726 & $\mathbf{7 2 5} ; 579 ; 446 ; 284 ; 178$ & $\begin{array}{l}\text { kaempferol }+ \text { pentose }+ \\
\text { hexose+ rhamnose }\end{array}$ \\
\hline & 4,01 & $199 ; 265 ; 347$ & 610 & $\mathbf{6 0 9} ; 464 ; 301 ; 271$ & $\begin{array}{l}\text { quercetina + hexose + } \\
\text { rhamnose (rutina) }\end{array}$ \\
\hline 8 & 4,36 & $202 ; 254 ; 353$ & 756 & $\mathbf{7 5 5} ; 609 ; 447 ; 299 ; 271 ; 151$ & $\begin{array}{l}\text { quercetina + di- } \\
\text { rhamnose + hexose }\end{array}$ \\
\hline 9 & 4,61 & $202 ; 354$ & 580 & $\mathbf{5 7 9} ; 447 ; 301 ; 271 ; 151$ & $\begin{array}{c}\text { quercetina + rhamnose } \\
+ \text { pentose }\end{array}$ \\
\hline 10 & 4,76 & 202 & 596 & $\mathbf{5 9 5} ; 300 ; 271 ; 178$ & derivado de quercetina \\
\hline 11 & 4,87 & $201 ; 348$ & 594 & $\mathbf{5 9 3} ; 447 ; 300 ; 283 ; 271 ; 178$ & quercetina di-rhamnose \\
\hline 12 & 5,03 & $199 ; 265 ; 343$ & 696 & $\mathbf{6 9 5} ; 549 ; 284 ; 178$ & $\begin{array}{l}\text { kaempferol + di- } \\
\text { pentose+ rhamnose }\end{array}$ \\
\hline 13 & 5,31 & $199 ; 265 ; 348$ & 564 & $\mathbf{5 6 3} ; 430 ; 283 ; 255 ; 117$ & $\begin{array}{c}\text { kaempferol + rhamnose } \\
+ \text { pentose }\end{array}$ \\
\hline 14 & 5,39 & $199 ; 264 ; 347$ & 740 & $\mathbf{7 9 3} ; 593 ; 431 ; 285 ; 255$ & $\begin{array}{l}\text { kaempferol + di- } \\
\text { rhamnose + hexose }\end{array}$ \\
\hline 15 & 5,50 & $203 ; 254 ; 348$ & 594 & $\mathbf{5 9 3} ; 447 ; 301 ; 271 ; 151$ & $\begin{array}{l}\text { quercetina + di- } \\
\text { rhamnose }\end{array}$ \\
\hline \multirow{3}{*}{16} & 5,68 & $203 ; 253 ; 353$ & 624 & $\mathbf{6 2 3} ; 478 ; 315 ; 300$ & $\begin{array}{c}\text { isorhamnetina + hexose } \\
+ \text { rhamnose }\end{array}$ \\
\hline & 5,68 & $203 ; 253 ; 353$ & 462 & 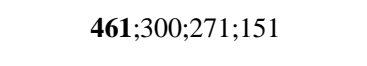 & $\begin{array}{l}\text { quercetina + hexose } \\
\text { (quercetrina) }\end{array}$ \\
\hline & 5,68 & $203 ; 253 ; 353$ & 610 & $\mathbf{6 0 9} ; 447 ; 300 ; 271 ; 151$ & $\begin{array}{c}\text { quercetina + hexose + } \\
\text { rhamnose (rutina) }\end{array}$ \\
\hline 17 & 5,73 & $203 ; 253 ; 353$ & 624 & $\mathbf{6 2 3} ; 461 ; 315 ; 300 ; 255 ; 125$ & $\begin{array}{l}\text { isorhamnetina + di- } \\
\text { rhamnose + hexose }\end{array}$ \\
\hline \multirow[b]{2}{*}{18} & 5,90 & $203 ; 253 ; 354$ & 566 & $\mathbf{5 6 5} ; 300 ; 271 ; 151$ & quercetina + di-pentose \\
\hline & 5,90 & $203 ; 253 ; 354$ & 594 & $\mathbf{5 9 3} ; 447 ; 315 ; 270 ; 197$ & $\begin{array}{l}\text { 1Sorhamnetina + } \\
\text { pentose + rhamnose }\end{array}$ \\
\hline 19 & 5,96 & $203 ; 351$ & 464 & $\mathbf{4 6 3} ; 301 ; 271 ; 151$ & $\begin{array}{l}\text { quercetina + hexose } \\
\text { (quercetrina) }\end{array}$ \\
\hline 20 & 6,08 & $203 ; 265$ & 580 & $\mathbf{5 7 9} ; 284 ; 255 ; 178$ & derivado da kaempferol \\
\hline 21 & 6,17 & $204 ; 347$ & 594 & $\mathbf{5 9 3} ; 460 ; 315 ; 284 ; 178$ & $\begin{array}{l}\text { derivado isorhamnetina } \\
+ \text { kaempferol }\end{array}$ \\
\hline 22 & 6,49 & $198 ; 264 ; 342$ & 578 & $\mathbf{5 7 7} ; 431 ; 285 ; 255$ & $\begin{array}{l}\text { kaempferol + di- } \\
\text { rhamnose }\end{array}$ \\
\hline \multirow[t]{2}{*}{23} & 6,62 & $198 ; 264 ; 343$ & 710 & 709;563;433;300 & $\begin{array}{l}\text { kaempferol +di- } \\
\text { rhamnose + pentose }\end{array}$ \\
\hline & 6,62 & $198 ; 264 ; 343$ & 434 & $\mathbf{4 3 3} ; 300 ; 271$ & quercetina + pentose \\
\hline 24 & 6,78 & $203 ; 253 ; 347$ & 608 & $\mathbf{6 0 7} ; 461 ; 315 ; 300$ & $\begin{array}{l}\text { isorhamnetina + di- } \\
\text { rhamnose }\end{array}$ \\
\hline 25 & 6,87 & $204 ; 347$ & 740 & 739;593;460;314;285;178 & $\begin{array}{l}\text { isorhamnetina + di- } \\
\text { rhamnose + pentose }\end{array}$ \\
\hline 26 & 7,15 & $206 ; 353$ & 624 & $\mathbf{6 2 3} ; 477 ; 315 ; 284 ; 204 ; 129$ & $\begin{array}{c}\text { isorhamnetina + hexose } \\
\text { + rhamnose }\end{array}$ \\
\hline 27 & 7,24 & $206 ; 347$ & 448 & $\mathbf{4 4 7 ; 3 0 1 ; 2 7 1 ; 1 5 1 ~}$ & quercetina + rhamnose \\
\hline 28 & 7,46 & $210 ; 354$ & 478 & $\mathbf{4 7 7 ; 3 1 4 ; 2 7 1 ; 2 4 3 ; 1 5 1 ~}$ & isorhamnetina + hexose \\
\hline 29 & 7,96 & 204 & 448 & $\mathbf{4 4 7} ; 314 ; 300 ; 271 ; 243 ; 153$ & derivado quercetina \\
\hline 30 & 8,05 & 204 & 432 & $\mathbf{4 3 1 ; 2 8 5 ; 2 5 5 ; 2 2 7}$ & kaempferol + rhamnose \\
\hline
\end{tabular}

Fonte: Própria autoria. 


\subsection{Caracterização das soluções filmogênicas de gelatina}

\subsubsection{Propriedades reológicas das soluções de gelatina}

\subsubsection{Testes de varredura de deformação}

Os testes de varredura de deformação foram realizados para determinação do intervalo de viscoelasticidade linear. As análises foram realizadas à 50 (domínio sol) e a $5^{\circ} \mathrm{C}$ (domínio gel), que foram os extremos de temperaturas utilizados em todas as análises, obtendo-se dessa forma, um intervalo comum às duas temperaturas.

Um exemplo de uma das curvas obtidas à $50^{\circ} \mathrm{C}$ encontra-se na Figura 17 , onde somente o módulo de perda (G”) foi representado, porque os valores do módulo de armazenamento (G') foram inferiores ao limite de detecção do equipamento. É sabido que o módulo de armazenamento é um parâmetro reológico característico do sólido viscoelástico (CASSU; FELISBERTI, 2005). Como a solução encontrava-se no domínio sol justificam-se os valores não detectáveis para o G'.

Figura 17: Exemplo de curva de varredura de deformação da solução de gelatina à $50^{\circ} \mathrm{C}$

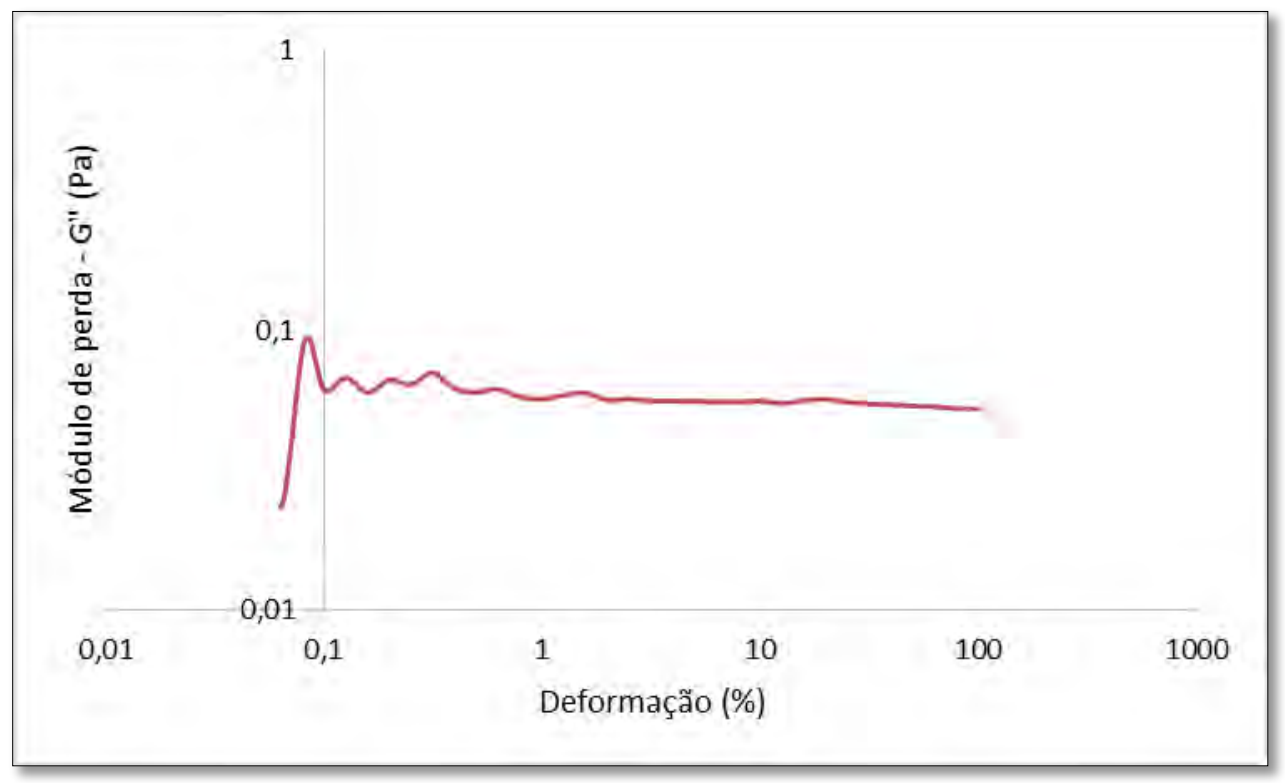

Fonte: Própria autoria 
A $5^{\circ} \mathrm{C}$, observou-se o módulo de armazenamento (G') e o módulo de perda (G’), contudo, constatou-se que a diferença entre essas respostas foi da ordem de $10^{1}$ (Figura 18).

Figura 18: Exemplo de curva de varredura de deformação da solução de gelatina à $5^{\circ} \mathrm{C}$

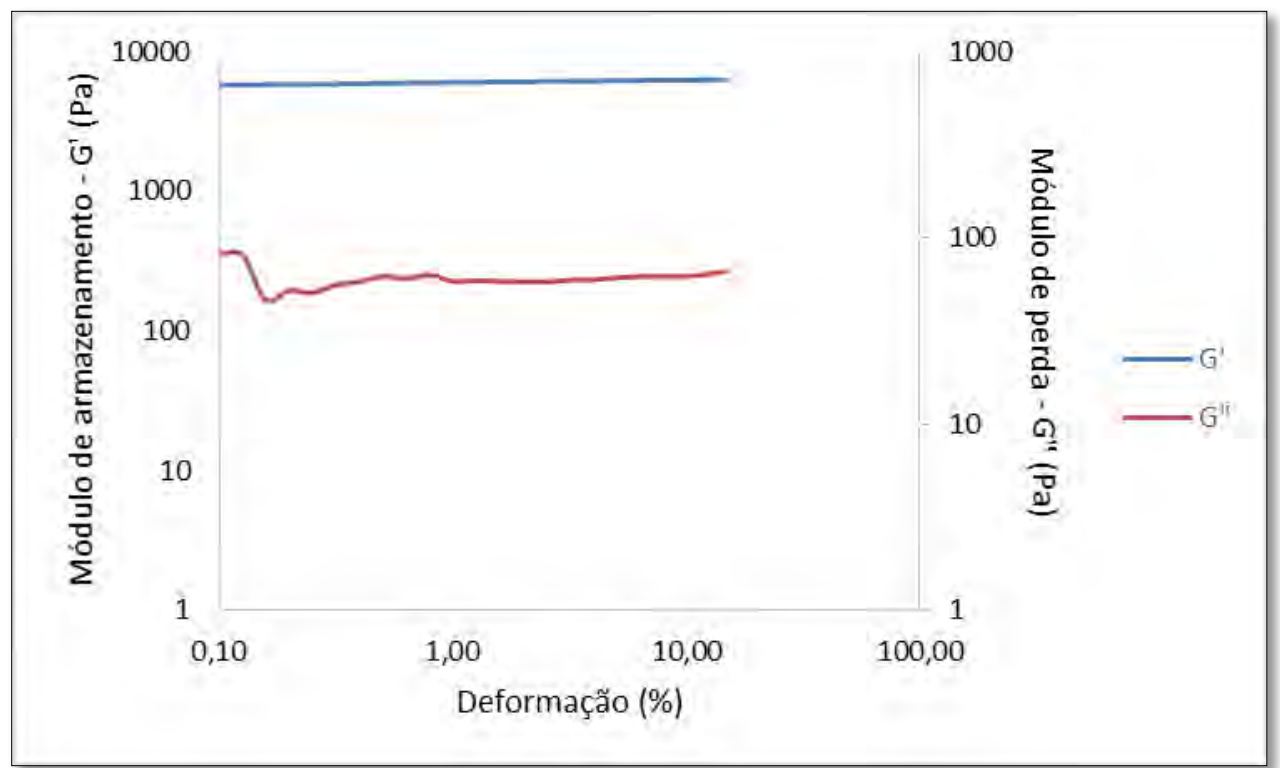

Fonte: Própria autoria

A partir da avaliação dos resultados obtidos, verificou-se que todo o intervalo estudado correspondia ao domínio da viscoelasticidade linear, mas optou-se por considerar seu começo em $1 \%$ de deformação, quando as perturbações se tornaram desprezíveis. Os resultados obtidos neste estudo corroboram com Sarbon, Badii e Howell (2015), que trabalharam com soluções de gelatina de pele de frango ( $10 \mathrm{~g}$ de gelatina/100mL de água), e encontraram que $1 \%$ se encontra no domínio da viscoelasticidade linear. Entretanto, a fim de assegurar a permanência no intervalo de viscoelasticidade linear, neste trabalho optou-se por utilizar uma deformação equivalente à $2 \%$ para todos os testes.

\subsubsection{Testes de varredura de temperatura}

O comportamento viscoelástico ( $G^{\prime}$ e G”) foi similar para todas as formulações: valores superiores de G' para baixas temperaturas e valores superiores de G” para altas 
temperaturas (Figura 19). Esse comportamento é típico de géis físicos que apresentam transições sol-gel e gel-sol, quando a solução é resfriada e aquecida, respectivamente. A temperatura de transição é determinada da inflexão abrupta das rampas de resfriamento e aquecimento (GÓMEZ-ESTACA et al., 2009d; JORGE et al., 2014; KIM; MIN, 2012; MORAES et al., 2009).

Figura 19: Exemplo de curva de varredura de temperatura para a solução de gelatina elaborada com $8 \mathrm{~g} / 100 \mathrm{~g}$ de gelatina e $150 \mathrm{~g}$ de boldo/100g de gelatina.

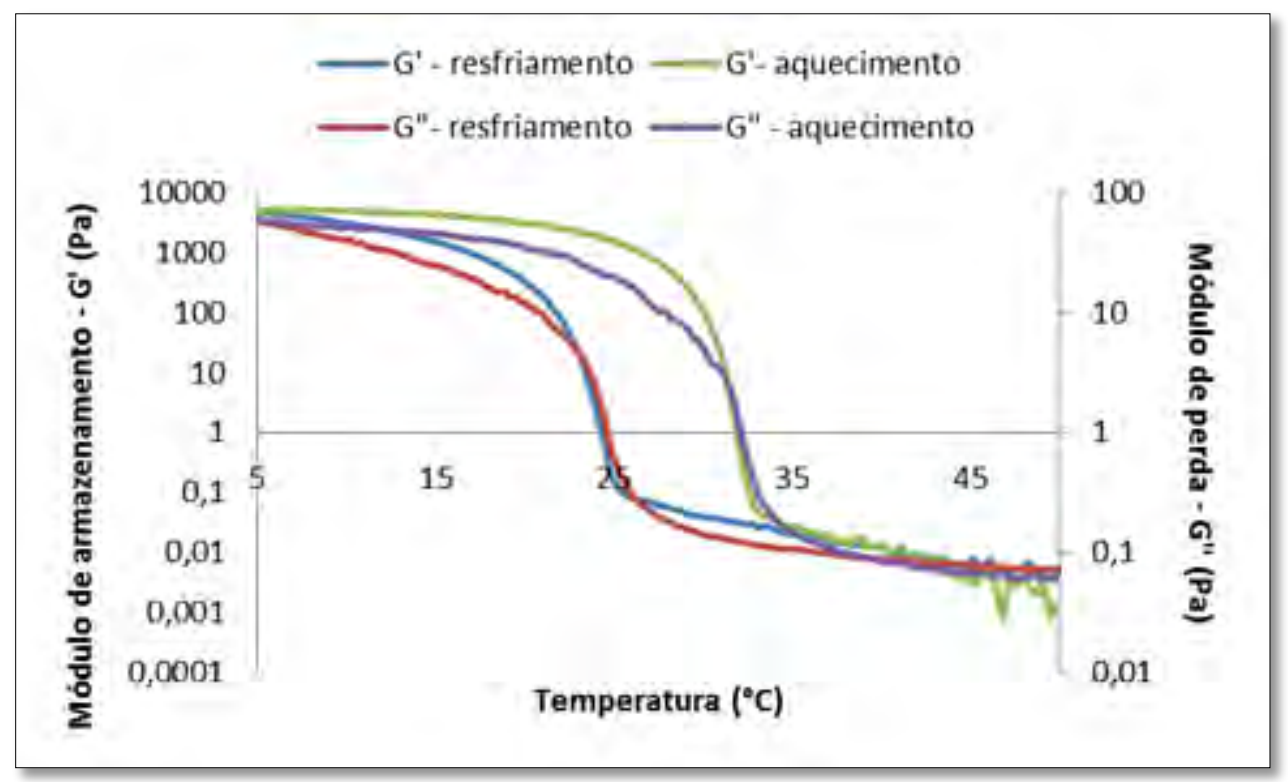

Fonte: Própria autoria.

Pode-se observar na Tabela 10 que o aumento da concentração de gelatina implicou em um aumento das temperaturas de transição sol-gel ( T $_{\text {SOL-GEL }}$ ) e gel-sol (T GEL- $_{\text {- }}$ sol) $(\mathrm{p}<0,05)$, sendo que o aumento foi maior para TsOL-GEL. De acordo com Fitzsimons, Mulvihill e Morris (2008) esse comportamento pode ser associado a processo de formação da tripla hélice de gelatina esse processo é lento e dependente da concentração das macromoléculas, enquanto que a dissociação da tripla hélice (fusão) é um processo de equilíbrio relacionado somente com a temperatura de transição. A temperatura sol-gel variou de 12 à $25^{\circ} \mathrm{C}$, em média, para 2 e $8 \mathrm{~g}$ de gelatina $/ 100 \mathrm{~g}$ de $\mathrm{SF}$, respectivamente. Já a $\mathrm{T}_{\mathrm{GEL}-S O L}$ foi igual à 27 para as soluções com $2 \mathrm{~g}$ de gelatina/100g de $\mathrm{SF}$ e de $31^{\circ} \mathrm{C} \mathrm{em}$ soluções contendo $8 \mathrm{~g}$ de gelatina/100g de SF. Isso pode ser atribuído à uma maior proximidade das moléculas de gelatina para soluções mais concentradas, permitindo tanto a formação do gel em temperaturas maiores. 
Tabela 10: Valores para as temperaturas de transição $T_{\text {SOL-GEL }}$ e $T_{\text {GEL-SOL }}$

\begin{tabular}{ccccccc}
\hline \multirow{2}{*}{$\mathbf{C}_{\text {GEL }}$} & \multicolumn{3}{c}{ T $_{\text {SOL-GEL }}\left({ }^{\circ} \mathbf{C}\right)$} & & \multicolumn{3}{c}{ T $_{\text {GEL-SOL }}\left({ }^{\circ} \mathbf{C}\right)$} \\
& Controle & $\mathbf{5 0}$ & $\mathbf{1 5 0}$ & Controle & $\mathbf{5 0}$ & $\mathbf{1 5 0}$ \\
\hline $\mathbf{2}$ & $12,9 \pm 0,6^{\mathrm{D}, \mathrm{a}}$ & $13,0 \pm 0,5^{\mathrm{D}, \mathrm{a}}$ & $12,6 \pm 0,4^{\mathrm{D}, \mathrm{a}}$ & $27,8 \pm 0,3^{\mathrm{B}, \mathrm{a}}$ & $28,0 \pm 0,3^{\mathrm{C}, \mathrm{a}}$ & $27,5 \pm 0,3^{\mathrm{C}, \mathrm{a}}$ \\
$\mathbf{4}$ & $18,9 \pm 0,5^{\mathrm{C}, \mathrm{a}}$ & $18,7 \pm 0,3^{\mathrm{C}, \mathrm{a}}$ & $18,8 \pm 0,4^{\mathrm{C}, \mathrm{a}}$ & $30,3 \pm 0,3^{\mathrm{A}, \mathrm{a}}$ & $30,1 \pm 0,5^{\mathrm{B}, \mathrm{a}}$ & $30,1 \pm 0,4^{\mathrm{B}, \mathrm{a}}$ \\
$\mathbf{6}$ & $22,7 \pm 0,4^{\mathrm{B}, \mathrm{a}}$ & $22,2 \pm 0,5^{\mathrm{B}, \mathrm{a}}$ & $22,1 \pm 0,5^{\mathrm{B}, \mathrm{a}}$ & $30,6 \pm 0,6^{\mathrm{A}, \mathrm{a}}$ & $30,9 \pm 0,4^{\mathrm{AB}, \mathrm{a}}$ & $31,2 \pm 0,4^{\mathrm{AB}, \mathrm{a}}$ \\
$\mathbf{8}$ & $25,7 \pm 0,8^{\mathrm{A}, \mathrm{a}}$ & $25,5 \pm 0,6^{\mathrm{A}, \mathrm{a}}$ & $25,4 \pm 0,7^{\mathrm{A}, \mathrm{a}}$ & $31,3 \pm 0,6^{\mathrm{A}, \mathrm{a}}$ & $31,9 \pm 0,4^{\mathrm{A}, \mathrm{a}}$ & $31,6 \pm 0,7^{\mathrm{A}, \mathrm{a}}$ \\
\hline
\end{tabular}

Fonte: Própria autoria.

$\mathrm{C}_{\mathrm{GEL}}$ : Concentração de gelatina em g/100g de SF; Controle: formulação sem boldo; 50 : formulação com $50 \mathrm{~g}$ de extrato de boldo/100g de gelatina; 150 : formulação com $150 \mathrm{~g}$ de extrato de boldo/100g de gelatina.

A,B letras maiúsculas diferentes na mesma coluna indicam diferença significativa para o mesmo parâmetro.

a,b letras minúsculas diferentes na mesma linha indicam diferença significativa para o mesmo parâmetro.

A adição do extrato do boldo-do-Chile não apresentou efeito sobre essas transições ( $>$ >0,05) (Tabela 10), sugerindo que os polifenóis presentes no extrato do boldo-do-Chile não interferiram na conformação das cadeias de gelatina na formação do gel. A não interação do extrato de boldo-do-Chile pode estar relacionada ao baixo teor de lisina reativa e também a ausência de ácidos fenólicos (ver no tópico 5.2.4) (CARVALHO; GROSSO, 2004; 2006; WANG et al., 2012).

A diferença entre a $\mathrm{T}_{\mathrm{SOL}-\mathrm{GEL}}$ e a $\mathrm{T}_{\mathrm{GEL}-\mathrm{SOL}}$ corresponde a histerese, que foi calculada e está apresentada na Tabela 11. Observou-se que a histerese foi função da concentração de gelatina, quanto maior a concentração de gelatina menor a histerese $(p>0,05)$, sem efeito da adição do extrato. Jorge et al. (2014) observaram um comportamento similar trabalhando com soluções de gelatinas adicionadas de montmorilonitas, sendo que quando menor a concentração de gelatina maior a histerese. 
Tabela 11: Histerese $(\Delta \mathrm{T})$ da temperatura das soluções ( $\mathrm{T}_{\mathrm{SOL}-\mathrm{GEL}}$ e $\left.\mathrm{T}_{\mathrm{GEL}-\mathrm{SOL}}\right)$ de gelatina em diferentes concentrações de macromoléculas e extrato de boldo-do-Chile.

\begin{tabular}{cccc}
\hline $\mathbf{C}_{\text {GEL }}$ & Controle & $\Delta \mathbf{T}\left({ }^{\circ} \mathbf{C}\right)$ \\
& $14,8 \pm 0,8^{\mathrm{A}, \mathrm{a}}$ & $\mathbf{5 0}$ & $\mathbf{1 5}$ \\
\hline $\mathbf{2}$ & $11,4 \pm 0,8^{\mathrm{B}, \mathrm{a}}$ & $15,1 \pm 0,6^{\mathrm{A}, \mathrm{a}}$ & $14,9 \pm 0,7^{\mathrm{A}, \mathrm{a}}$ \\
$\mathbf{4}$ & $7,8 \pm 0,8^{\mathrm{C}, \mathrm{a}}$ & $8,7 \pm 0,6^{\mathrm{B}, \mathrm{a}}$ & $11,3 \pm 0,7^{\mathrm{C}, \mathrm{a}}$ \\
$\mathbf{6}$ & $5,9 \pm 1,5^{\mathrm{C}, \mathrm{a}}$ & $7,6 \pm 1,3^{\mathrm{C}, \mathrm{a}}$ & $9,1 \pm 0,7^{\mathrm{B}, \mathrm{a}}$ \\
$\mathbf{8}$ & & $6,3 \pm 1,3^{\mathrm{C}, \mathrm{a}}$ \\
\hline
\end{tabular}

Fonte: Própria autoria.

$\mathrm{C}_{\mathrm{GEL}}$ : Concentração de gelatina em g/100g de SF; Controle: formulação sem boldo; 50 : formulação com $50 \mathrm{~g}$ de extrato de boldo/100g de gelatina; 150: formulação com $150 \mathrm{~g}$ de extrato de boldo/100g de gelatina.

A,B letras maiúsculas diferentes na mesma coluna indicam diferença significativa para o mesmo parâmetro.

a,b letras minúsculas diferentes na mesma linha indicam diferença significativa para o mesmo parâmetro.

Moraes et al. (2009) trabalharam com soluções de gelatina ( $2 \mathrm{~g}$ de gelatina/100g de $\mathrm{SF}$ ) e obtiveram temperatura de $\mathrm{T}_{\mathrm{SOL}-\mathrm{GEL}}$ em torno de $15,1^{\circ} \mathrm{C}$, e temperatura de $\mathrm{T}_{\mathrm{GEL}}$ SOL em torno de $28,5^{\circ} \mathrm{C}$, a taxa de aquecimento/resfriamento empregada foi de $1^{\circ} \mathrm{C} / \mathrm{min}$. Cho, Gub e Kim (2005) trabalharam com soluções de gelatina suína (6,67g de gelatina/100mL de água destilada) e obtiveram uma $\mathrm{T}_{\mathrm{SOL}-\mathrm{GEL}}$ igual a $25,6^{\circ} \mathrm{C}$, e uma $\mathrm{T}_{\mathrm{GEL}}$ sol de $36,5^{\circ} \mathrm{C}$ utilizando uma taxa de aquecimento/resfriamento de $0,5^{\circ} \mathrm{C} / \mathrm{min}$. GómezEstaca et al. (2009d) trabalharam com gelatina de couro bovino (4g de gelatina/100mL de água destilada) em uma taxa de aquecimento/resfriamento de $1^{\circ} \mathrm{C} / \mathrm{min}$ e encontraram 20,0 e $30,0^{\circ} \mathrm{C}$ para as temperaturas $\mathrm{T}_{\mathrm{SOL}-\mathrm{GEL}} \mathrm{e} \mathrm{T}_{\mathrm{GEL}-\mathrm{SOL}}$, respectivamente. Jorge et al. (2014) trabalharam em uma taxa de aquecimento/resfriamento de $1{ }^{\circ} \mathrm{C} / \mathrm{min}$ com gelatina de suíno (5 e $8 \%$ w/w) e encontraram temperaturas de transição sol-gel de $21,78^{\circ} \mathrm{C}$ para as soluções à $5 \%$ e $24,01^{\circ} \mathrm{C}$ para as soluções à $8 \%$. As temperaturas de transição gel-sol foram 30,52 e $31,08^{\circ} \mathrm{C}$, para as soluções de 5 e $8 \%$. As temperaturas obtidas nos estudos de Cho, Gub e Kim (2005) e Moraes et al. (2009), considerando as concentrações de gelatina, foram superiores as temperaturas encontradas neste estudo. Entretanto, os valores encontrados por Gómez-Estaca et al. (2009d) e Jorge et al. (2014), foram bastante próximos. Não existem dados na literatura que correlacionam a adição de polifenóis à variação das temperaturas de transição sol-gel e gel-sol. 


\subsubsection{Testes de varredura de frequência}

Os testes de varredura de frequência permitiram que fosse constada a força do gel produzido a partir dessas soluções. Segundo, Sarbon, Badii e Howell (2015), a força do gel pode ser obtida estudando-se o quanto G' depende da frequência. No caso da formação do gel ser equivalente à uma rede emaranhada, observa-se que G' depende da frequência, e no caso do gel ser formado a partir de ligações covalentes, a evolução de G' independe da frequência (SARBON; BADII; HOWELL, 2015) Redes emaranhadas resultam em géis fracos, ao passo que ligações covalentes implicam em géis fortes.

Assim, foi possível constatar que o módulo de armazenamento não depende da frequência (Figura 20), o que sugere que os géis formados a partir das soluções filmogênicas tratam-se de géis fortes. Sarbon, Badii e Howell (2015) justificam a força dos géis de gelatina baseando-se nas ligações hidrofóbicas formadas ao longo do processo de estruturação do gel.

Figura 20: Exemplo de curva de varredura de frequência para uma solução de gelatina elaborada com $8 \mathrm{~g} / 100 \mathrm{~g}$ de SF.

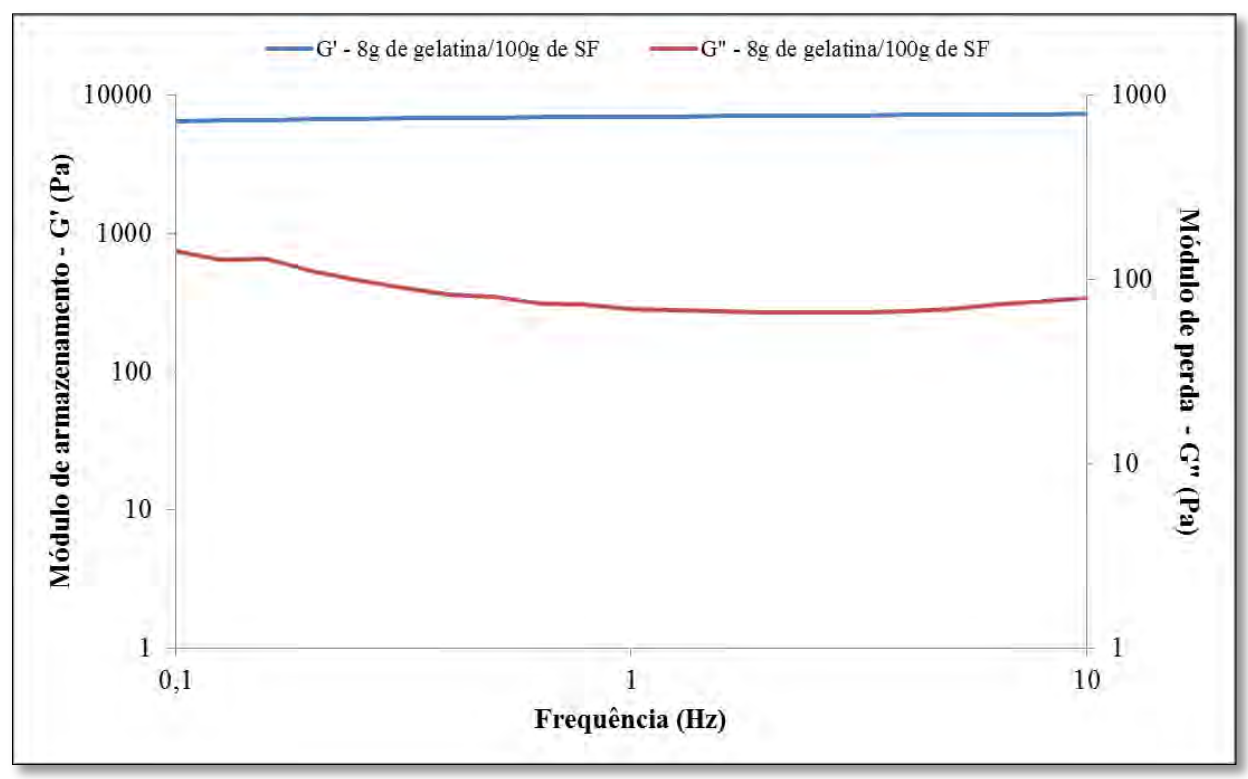

Fonte: Própria autoria 
Figura 21: Exemplos de curvas de varredura de frequência para todas as concentrações de extrato de boldo-do-Chile.

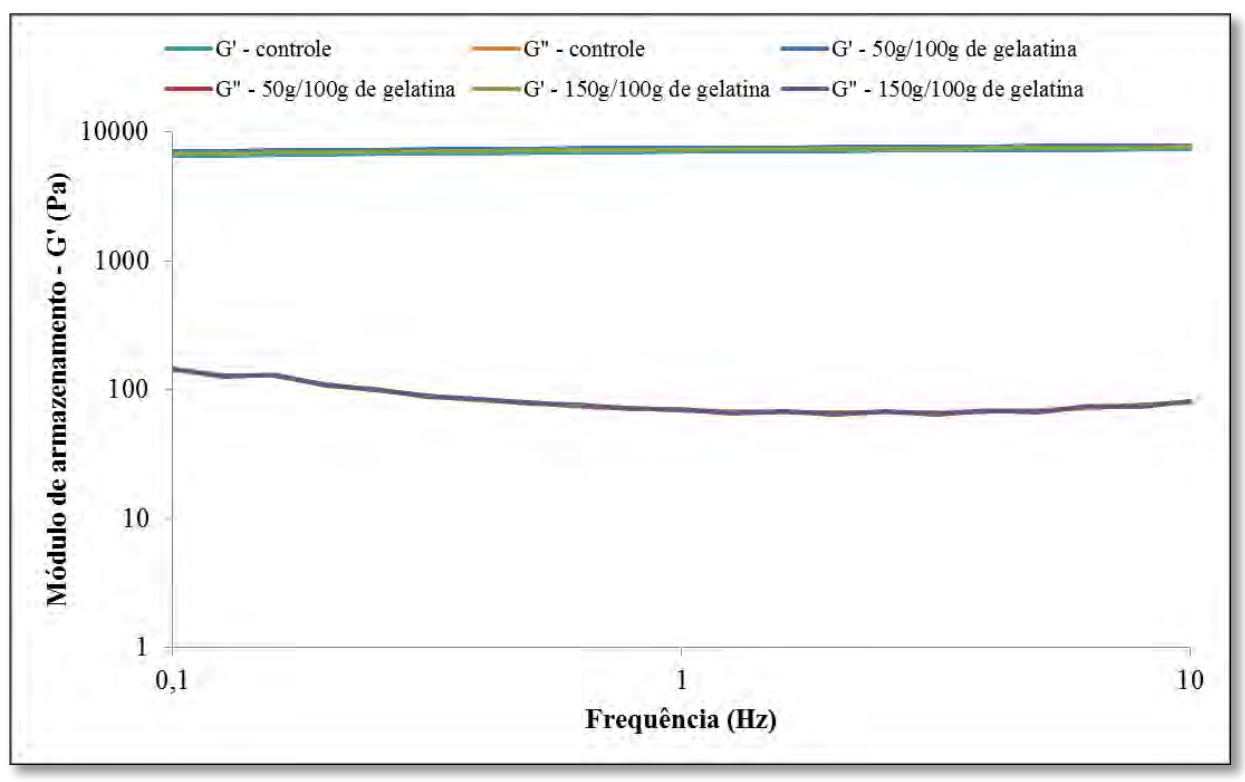

Fonte: Própria autoria

Não foi observada nenhuma diferença de comportamento em função da adição do extrato de bolo-do-Chile (Figura 21). Por outro lado, observou-se que o aumento da concentração de gelatina implicou em um aumento de G', ou seja, em géis mais fortes (Figura 22). Sarbon, Badii e Howell (2015) observaram um comportamento similar para os géis de gelatina elaborados com $10 \%$ de macromoléculas. 
Figura 22: Módulo de armazenamento - ( $\mathrm{G}^{\prime}$ em $\left.\mathrm{Pa}\right)$ em função da variação da frequência para as diferentes concentrações de gelatina.

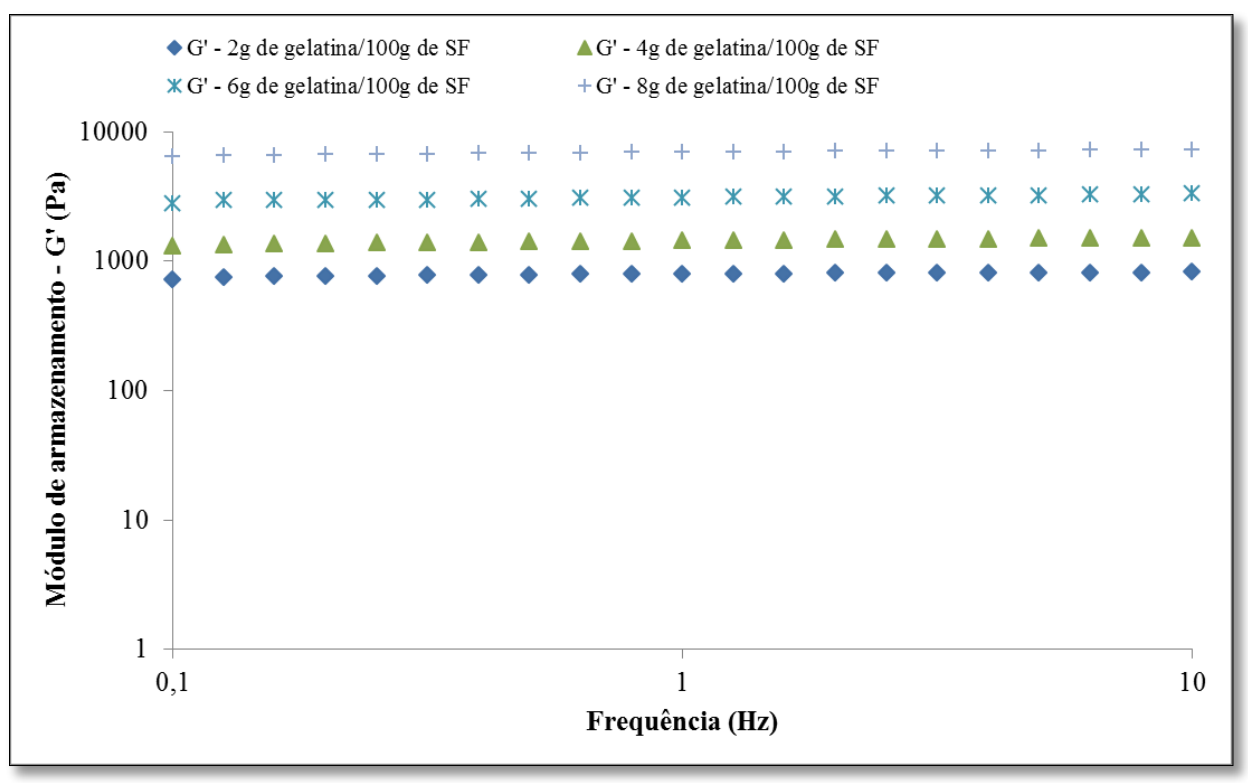

Fonte: Própria autoria

\subsubsection{Curvas de fluxo}

Observou-se que os comportamentos das curvas de fluxos das soluções filmogênicas de gelatina foram similares para todas as concentrações, e que a relação entre a taxa de cisalhamento e a taxa de deformação foi linear, ou seja, comportamento Newtoniano (Figura 23, 24, 25 e 26). Esse comportamento foi atribuído a baixa concentração de macromoléculas nas soluções filmogênicas, sendo essas consideradas como soluções relativamente diluídas, neste caso prevalecendo as interações macromolécula - água (BARRETO et al., 2003; MORAES et al., 2009). 
Figura 23: Curvas de fluxo das soluções com $2 \mathrm{~g}$ de gelatina/100g de $\mathrm{SF}$ (dados experimentais ajustados ao modelo Newtoniano)
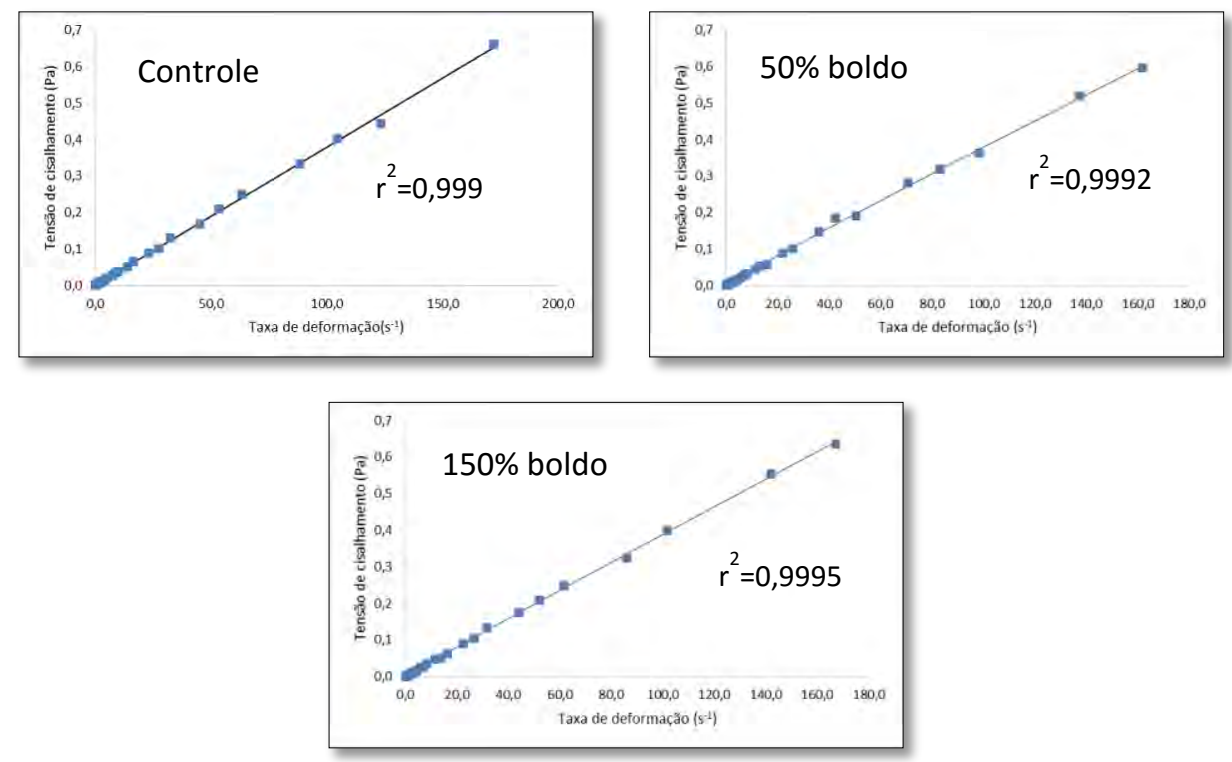

Fonte: Própria autoria.

Controle: formulação sem extrato de boldo; $50 \%$ boldo: formulação com $50 \mathrm{~g}$ de extrato de boldo/100g de gelatina; $150 \%$ boldo: formulação com $150 \mathrm{~g}$ de extrato de boldo/100g de gelatina.

Figura 24: Curvas de fluxo das soluções com $4 \mathrm{~g}$ de gelatina/100g de SF(dados experimentais ajustados ao modelo Newtoniano).
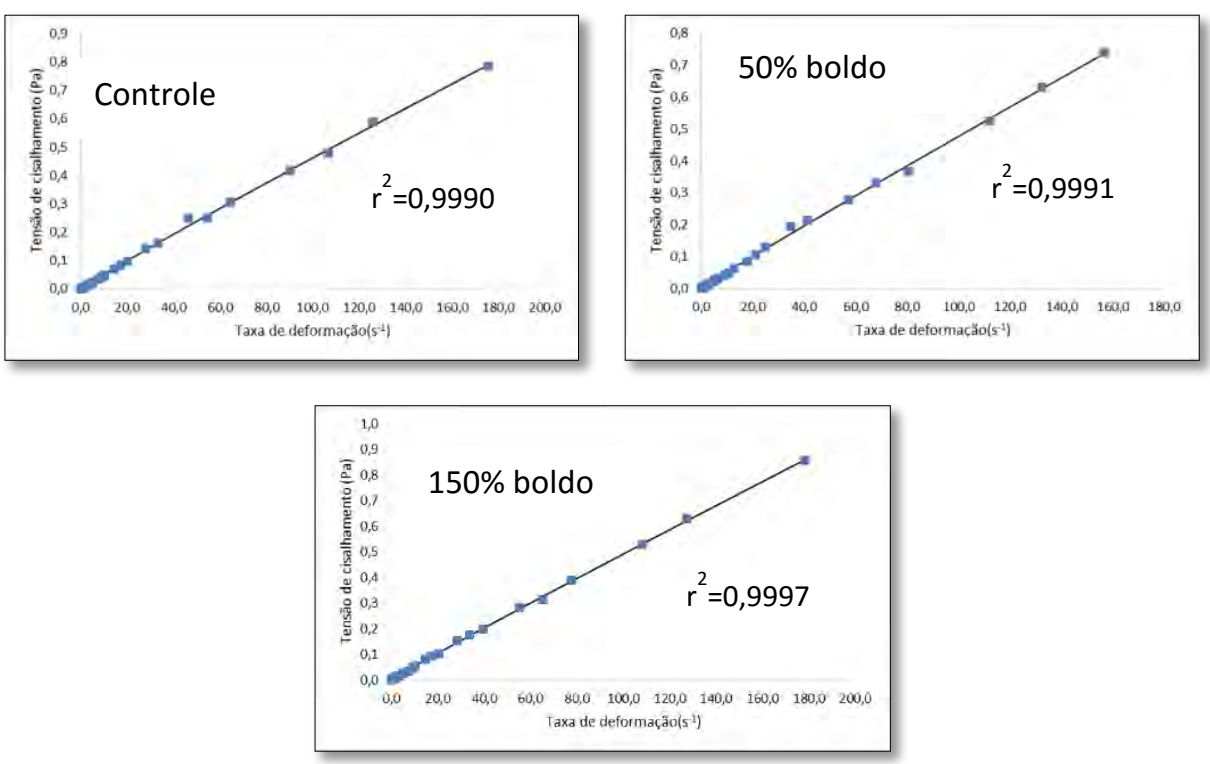

Fonte: Própria autoria.

Controle: formulação sem extrato de boldo; $50 \%$ boldo: formulação com $50 \mathrm{~g}$ de extrato de boldo/ $100 \mathrm{~g}$ de gelatina; $150 \%$ boldo: formulação com $150 \mathrm{~g}$ de extrato de boldo/100g de gelatina. 
Figura 25: Curvas de fluxo das soluções com $6 \mathrm{~g}$ de gelatina/100g de SF ajustadas ao modelo Newtoniano
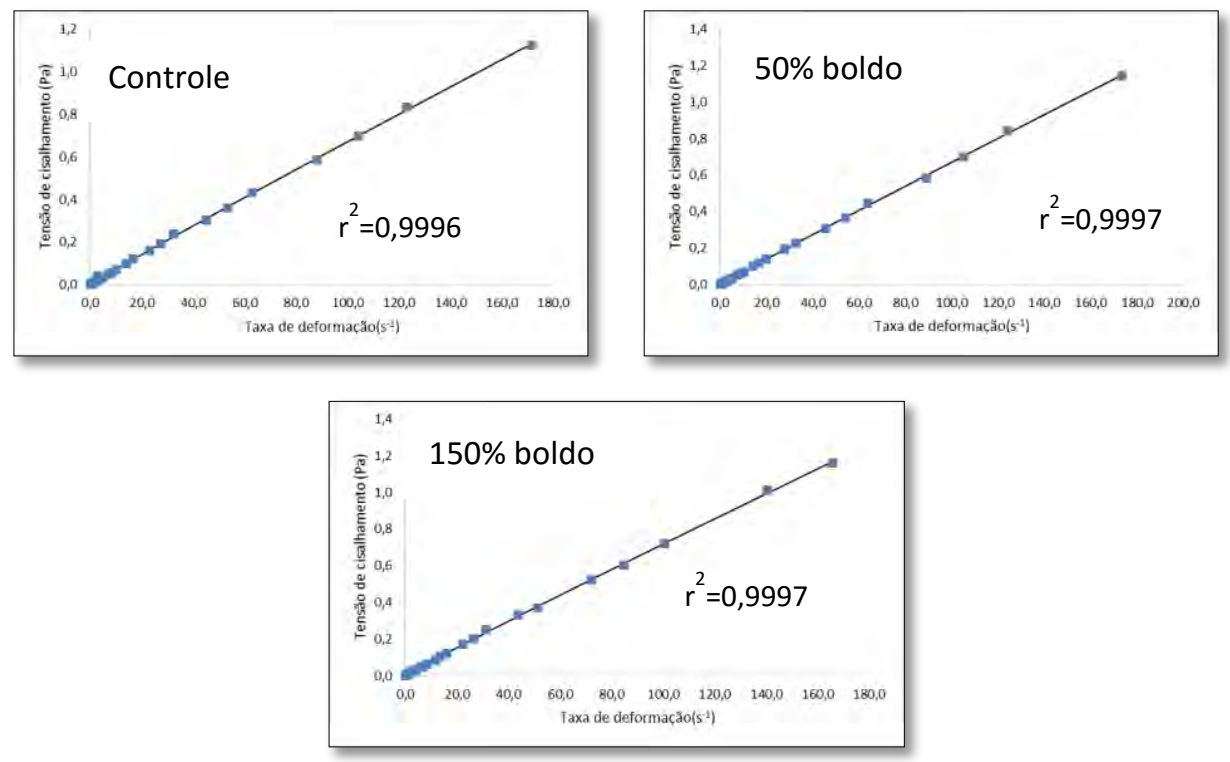

Fonte: Própria autoria.

Controle: formulação sem extrato de boldo; $50 \%$ boldo: formulação com $50 \mathrm{~g}$ de extrato de boldo/100g de gelatina; $150 \%$ boldo: formulação com $150 \mathrm{~g}$ de extrato de boldo/100g de gelatina.

Figura 26: Curvas de fluxo das soluções com $8 \mathrm{~g}$ de gelatina/100g de SF ajustadas ao modelo Newtoniano
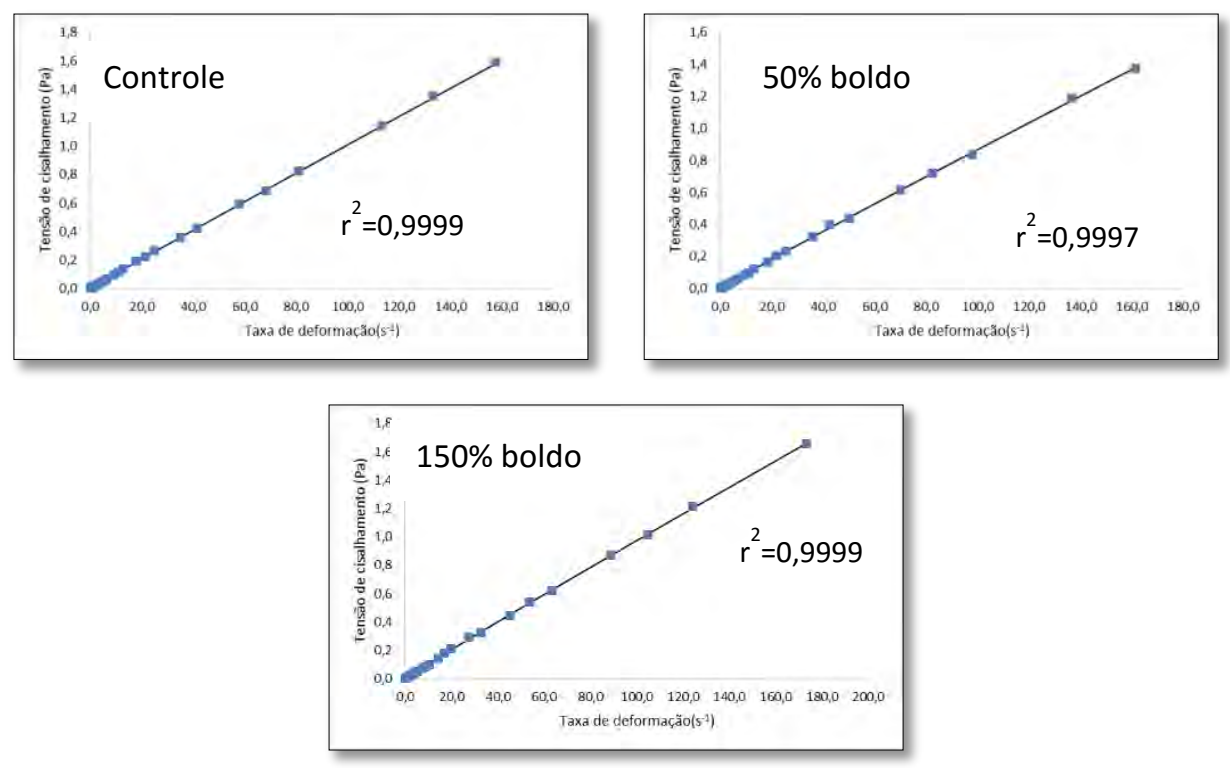

Fonte: Própria autoria

Controle: formulação sem extrato de boldo; $50 \%$ boldo: formulação com $50 \mathrm{~g}$ de extrato de boldo/ $100 \mathrm{~g}$ de gelatina; $150 \%$ boldo: formulação com $150 \mathrm{~g}$ de extrato de boldo/100g de gelatina. 
O aumento na concentração de gelatina implicou em um aumento na viscosidade das soluções filmogênicas (p<0,05) (Tabela 12), que variou de 3,8 à 9,8mPa.s para as soluções de 2 e $8 \mathrm{~g}$ de gelatina/100g de SF, respectivamente.

Assim como nas análises reológicas dinâmicas, não foi observado efeito da adição do extrato de boldo sobre a viscosidade das soluções filmogênicas ( $p>0,05$ ) (Tabela 12). Dessa forma, pode-se sugerir que a presença dos polifenóis contidos no extrato de boldodo-Chile não atuaram sobre as moléculas de gelatina de forma a provocar uma alteração no comportamento reológico das SF.

Tabela 12: Resultados obtidos para a viscosidade das soluções filmogênicas em diferentes concentrações.

\begin{tabular}{cccc}
\hline CGEL & \multicolumn{3}{c}{ Viscosidade (mPa.s) } \\
& Controle & $\mathbf{5 0}$ & $\mathbf{1 5 0}$ \\
\hline $\mathbf{2}$ & $3,8 \pm 0,0^{\mathrm{D}, \mathrm{a}}$ & $3,8 \pm 0,1^{\mathrm{D}, \mathrm{a}}$ & $3,9 \pm 0,0^{\mathrm{D}, \mathrm{a}}$ \\
$\mathbf{4}$ & $4,8 \pm 0,1^{\mathrm{C}, \mathrm{a}}$ & $4,8 \pm 0,0^{\mathrm{C}, \mathrm{a}}$ & $4,9 \pm 0,1^{\mathrm{C}, \mathrm{a}}$ \\
$\mathbf{6}$ & $6,7 \pm 0,1^{\mathrm{B}, \mathrm{a}}$ & $6,9 \pm 0,3^{\mathrm{B}, \mathrm{a}}$ & $7,0 \pm 0,2^{\mathrm{B}, \mathrm{a}}$ \\
$\mathbf{8}$ & $9,6 \pm 0,7^{\mathrm{A}, \mathrm{a}}$ & $9,3 \pm 0,2^{\mathrm{A}, \mathrm{a}}$ & $9,8 \pm 0,1^{\mathrm{A}, \mathrm{a}}$ \\
\hline
\end{tabular}

Fonte: Própria autoria.

$\mathrm{C}_{\mathrm{GEL}}$ : Concentração de gelatina em g/100g de SF; Controle: formulação sem boldo; 50 : formulação com $50 \mathrm{~g}$ de extrato de boldo/100g de gelatina; 150 : formulação com $150 \mathrm{~g}$ de extrato de boldo/100g de gelatina.

A,B letras maiúsculas diferentes na mesma coluna indicam diferença significativa para o mesmo parâmetro.

a,b letras minúsculas diferentes na mesma linha indicam diferença significativa para o mesmo parâmetro.

Moraes et al. (2009), trabalhando com soluções de gelatina, obtiveram o mesmo comportamento Newtoniano observado nesse estudo, entretanto a viscosidade encontrada por esses autores foi de 7,1mPa.s, para soluções de gelatina com $2 \%$.

Silva-Weiss et al. (2014), trabalhando com soluções de mistas de gelatina e carboximetilcelulose adicionadas de extrato de murta (Ugni molinae Turcz) obtiveram soluções não-Newtonianas cujo os dados dos ensaios reológicos se ajustaram ao modelo de lei de potência. A viscosidade aparente foi calculada com o modelo de Ostwald-deWaale, e esta diminuiu com a adição do extrato (sem extrato 3,30Pa.s e com extrato 0,48Pa.s). 
5.3.1.5 Testes oscilatórios ao longo do tempo

As análises realizadas ao longo do tempo (5 horas) mostraram os módulos de armazenamento (G') e módulo de perda (G”) não variaram ao longo do tempo. G' ficou bem próximo ao limite de detecção do equipamento, de forma que seus valores não puderam ser plotados no gráfico (Figura 27). Isso pode ser explicado pelo fato de G' estar associado ao sólido visco-elástico, e como os ensaios foram realizados à $50^{\circ} \mathrm{C}$, a fase viscosa foi predominante. Assim, os valores para G' foram bastante superiores aos de G'.

Figura 27: Exemplo de evolução do módulo de perda - G” ao longo do tempo (5h)

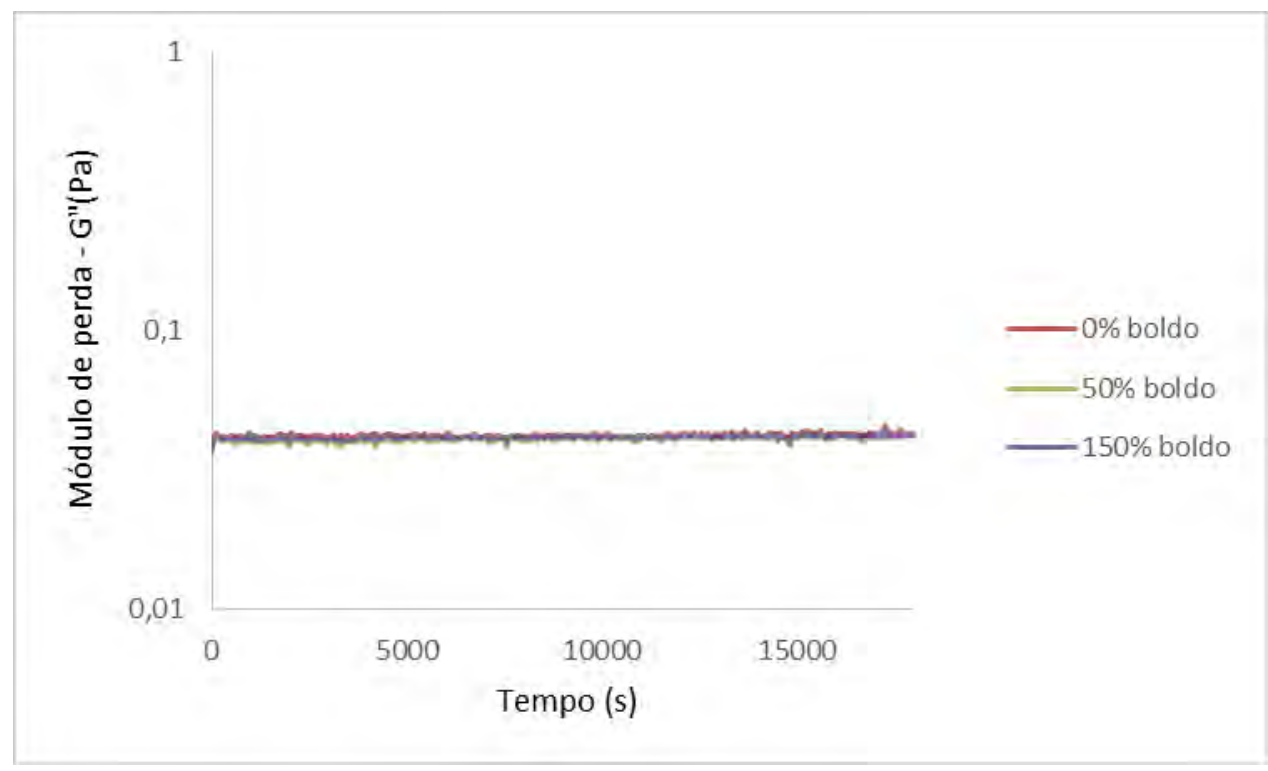

Fonte: Própria autoria

0\% boldo: formulação sem extrato de boldo; $50 \%$ boldo: formulação com $50 \mathrm{~g}$ de extrato de boldo/ $100 \mathrm{~g}$ de gelatina; $150 \%$ boldo: formulação com $150 \mathrm{~g}$ de extrato de boldo/100g de gelatina.

Hellio- Serughetti e Djabourov (2006 a,b) observaram que soluções de gelatina com concentrações superiores à 10\% e adicionadas de agentes reticulantes apresentaram uma evolução dos módulos de armazenamento e perda ao longo do tempo, em geral duas horas. De maneira que ocorreu uma inflexão na curva de G', onde foi possível identificar o momento da formação do gel em função do tempo (HELLIO- SERUGHETTI; DJABOUROV, 2006a,b). Esperava-se com os testes ao longo do tempo, que os polifenóis atuassem sobre as cadeias polipeptídicas provendo novas ligações, de forma que houvesse o incremento do módulo de armazenamento. Contudo, conforme já observado em testes 
anteriores, os compostos contidos no extrato de boldo-do-Chile não interagiram com as moléculas de gelatina, e por isso não houve efeito sobre a evolução de G' e G” ao longo do tempo.

\subsubsection{Análises térmicas das soluções de gelatina}

Nas análises térmicas realizadas por microcalorimetria foram realizadas quatro rampas de programação indicadas de I a IV que resultaram em termogramas como o apresentado na Figura 28. Primeiramente, a amostra permaneceu à $50^{\circ} \mathrm{C}$ por 5 minutos (isoterma - I), para garantir que a amostra estivesse completamente líquida ao início da análise. Nesse caso, foi observado um pico endotérmico relativo à fusão de partes já gelificadas antes do início da análise. Em II, foi realizado o resfriamento da amostra de 50 à $5^{\circ} \mathrm{C}$ e observou-se um pico exotérmico relativo à formação do gel, e em III, foi realizada uma isoterma à $5^{\circ} \mathrm{C}$, que variou em tempos de 30, 60 e 90 minutos. Em seguida, em IV, a solução de gelatina foi aquecida à $50^{\circ} \mathrm{C}$ para a fusão do gel, sendo observado o pico endotérmico de interesse.

Durante a fusão do gel, no início da rampa de aquecimento, observou-se a formação de um "ombro", que pode ser atribuído a heterogeneidade da gelatina utilizada (SARBON; BADII; HOWELL, 2015). 
Figura 28: Exemplo de termograma de uma solução $8 \mathrm{~g}$ de gelatina/100g de solução filmogênica temperatura ; fluxo de calor) com uma isoterma à $5^{\circ} \mathrm{C}$ de 90minutos.

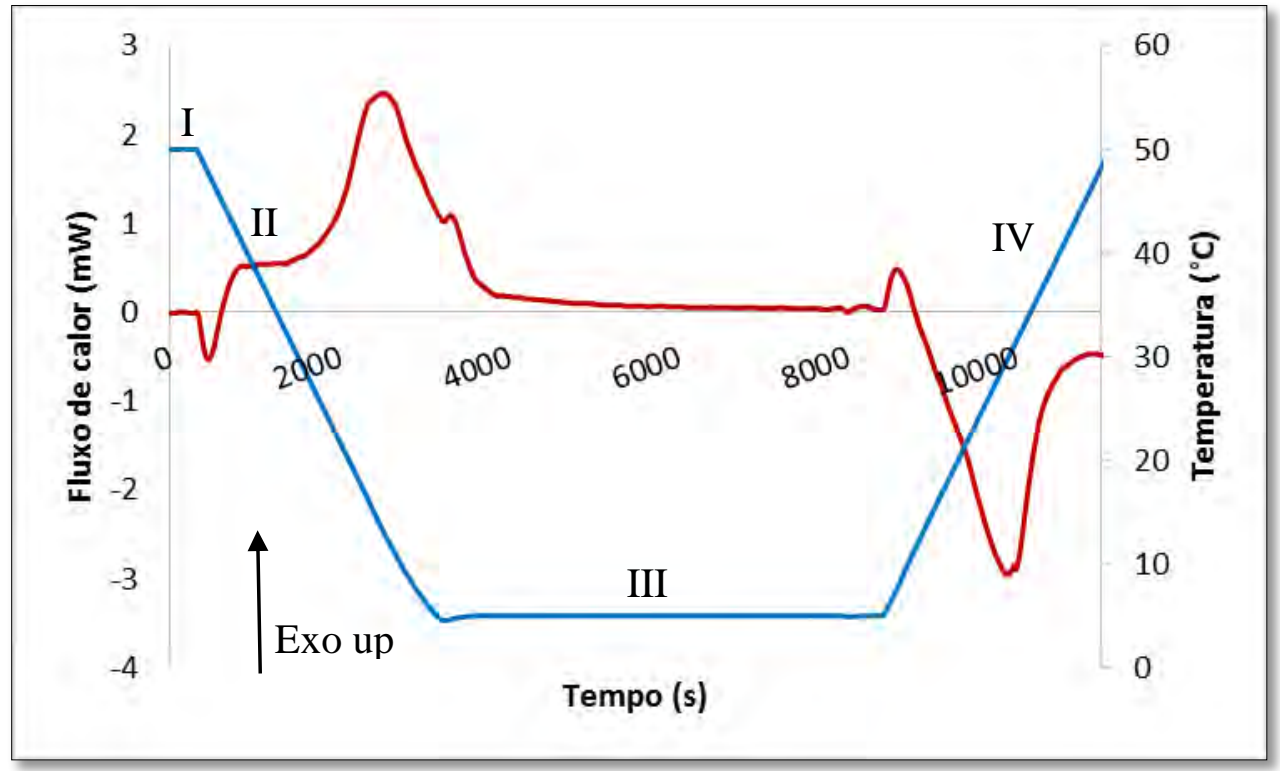

Fonte: Própria autoria.

$\mathrm{Na}$ Figura 29 têm-se exemplos de trechos das curvas obtidas ao longo do aquecimento (zona IV na Figura 28). A área sobre os picos corresponde à entalpia de fusão da gelatina ( $\Delta \mathrm{H}$ em $\mathrm{J} / \mathrm{g})$. Observou-se que o aumento na concentração de gelatina implicou em picos mais evidentes, entretanto, nem a variação da concentração de gelatina, nem a adição do extrato aquoso de boldo-do-Chile, influenciaram a temperatura de fusão ( $p>0,05)$, determinada como a temperatura onde ocorreu o pico endotérmico, sendo que a temperatura média ficou em torno de $29,5 \pm 0,3^{\circ} \mathrm{C}$ (Tabela 13). Esse resultado foi bastante próximo ao determinado por Sarbon, Badii e Howell (2015) ( $\mathrm{T}_{\text {média }}=31,0 \pm 0,2^{\circ} \mathrm{C}$ ), que também observaram pouca variação na temperatura de pico de fusão, em função da adição de isolado proteico de soro de leite nas soluções de gelatina. Diaz -Caldéron et al. (2014) encontraram uma discreta variação na temperatura de fusão $\left(31\right.$ à $\left.33^{\circ} \mathrm{C}\right)$ em função da concentração de gelatina bovina, entre 1,5 e 20\% (m/v). 
Figura 29: Exemplos da zona IV que foi integrada para obtenção da entalpia de fusão $(\Delta \mathrm{H} \mathrm{em} \mathrm{J/g)}$

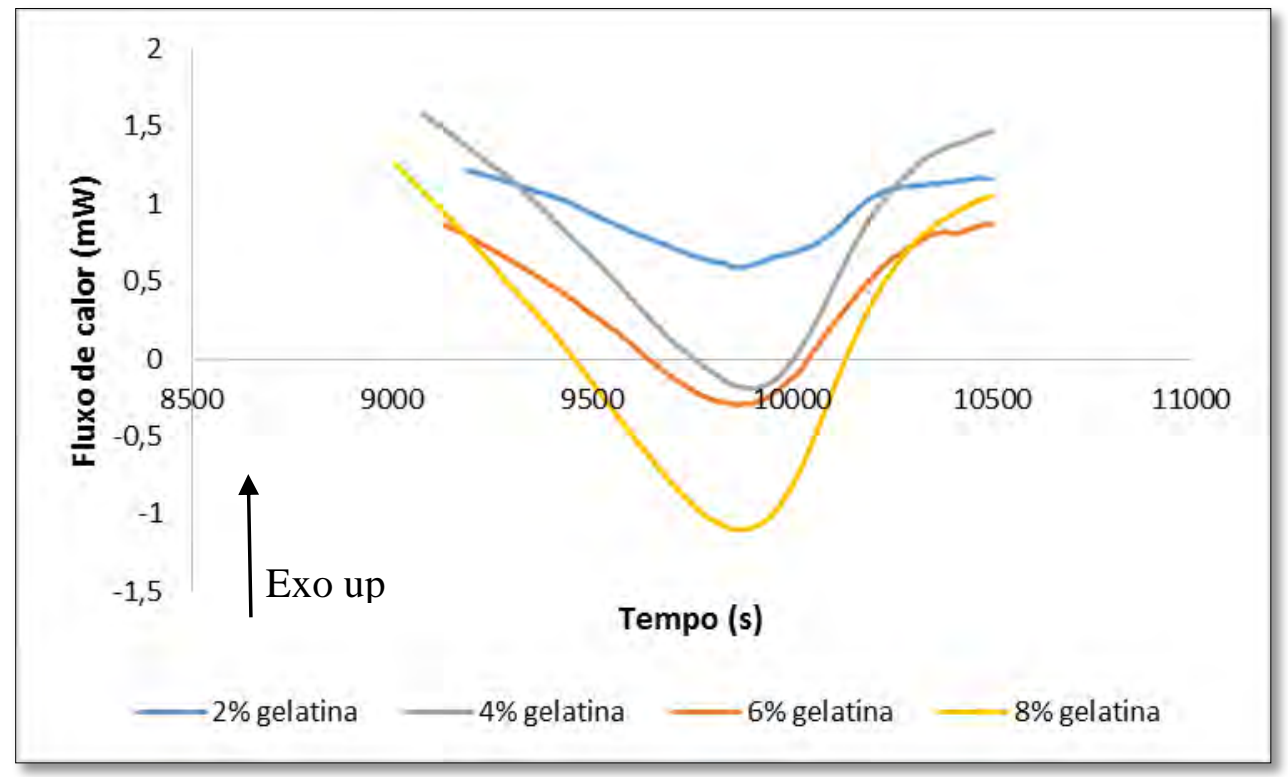

Fonte: Própria autoria.

Esses resultados podem ser correlacionados aos obtidos por reologia nos testes de varredura de temperatura, quando a fusão dos géis ocorreu em torno dos $30^{\circ} \mathrm{C}$. Da mesma forma, pode-se correlacionar à independência do fenômeno de dissociação das ligações tripla hélice da concentração de macromoléculas (FITZSIMONS; MULVIHILL; MORRIS, 2008). E no caso deste estudo, essa dissociação também foi independentemente da concentração do extrato adicionado. 
Tabela 13: Temperatura de fusão dos géis de gelatina determinada nos ensaios de $\mu \mathrm{DSC}$ realizados segundo a metodologia descrita

\begin{tabular}{|c|c|c|c|c|c|c|c|c|c|}
\hline \multirow{3}{*}{$\begin{array}{c}\text { CGEL } \\
\text { (g/100g de } \\
\text { solução) }\end{array}$} & \multicolumn{9}{|c|}{ Temperatura de pico de fusão $\left({ }^{\circ} \mathrm{C}\right)$} \\
\hline & \multicolumn{3}{|c|}{30 minutos $^{(2)}$} & \multicolumn{3}{|c|}{60 minutos } & \multicolumn{3}{|c|}{90 minutos } \\
\hline & CONTROLE & 50 & 150 & CONTROLE & 50 & 150 & CONTROLE & 50 & 150 \\
\hline 2 & $29,4 \pm 0,4^{\mathrm{A}, \mathrm{a}}$ & $28,8 \pm 0,1^{\mathrm{A}, \mathrm{a}}$ & $29,7 \pm 0,2^{\mathrm{A}, \mathrm{a}}$ & $29,1 \pm 0,6^{\mathrm{A}, \mathrm{a}}$ & $29,3 \pm 0,1^{\mathrm{A}, \mathrm{a}}$ & $29,4 \pm 0,3^{\mathrm{A}, \mathrm{a}}$ & $29,3 \pm 0,3^{\mathrm{A}, \mathrm{a}}$ & $29,2 \pm 0,3^{\mathrm{A}, \mathrm{a}}$ & $28,5 \pm 0,5^{\mathrm{A}, \mathrm{a}}$ \\
\hline 4 & $29,7 \pm 0,1^{\mathrm{A}, \mathrm{a}}$ & $29,0 \pm 0,3^{\mathrm{A}, \mathrm{a}}$ & $29,2 \pm 0,2^{\mathrm{A}, \mathrm{a}}$ & $29,6 \pm 0,1^{\mathrm{A}, \mathrm{a}}$ & $29,5 \pm 0,2^{\mathrm{A}, \mathrm{a}}$ & $29,4 \pm 0,1^{\mathrm{A}, \mathrm{a}}$ & $29,6 \pm 0,3^{\mathrm{A}, \mathrm{a}}$ & $29,5 \pm 0,3^{\mathrm{A}, \mathrm{a}}$ & $29,0 \pm 0,2^{\mathrm{A}, \mathrm{a}}$ \\
\hline 6 & $29,8 \pm 0,4^{\mathrm{A}, \mathrm{a}}$ & $29,6 \pm 0,1^{\mathrm{A}, \mathrm{a}}$ & $29,8 \pm 0,1^{\mathrm{A}, \mathrm{a}}$ & $29,7 \pm 0,3^{\mathrm{A}, \mathrm{a}}$ & $29,5 \pm 0,4^{\mathrm{A}, \mathrm{a}}$ & $29,6 \pm 0,1^{\mathrm{A}, \mathrm{a}}$ & $29,8 \pm 0,2^{\mathrm{A}, \mathrm{a}}$ & $29,8 \pm 0,2^{\mathrm{A}, \mathrm{a}}$ & $29,5 \pm 0,4^{\mathrm{A}, \mathrm{a}}$ \\
\hline 8 & $29,6 \pm 0,1^{\mathrm{A}, \mathrm{a}}$ & $29,4 \pm 0,6^{\mathrm{A}, \mathrm{a}}$ & $29,8 \pm 0,2^{\mathrm{A}, \mathrm{a}}$ & $29,6 \pm 0,1^{\mathrm{A}, \mathrm{a}}$ & $29,9 \pm 0,2^{\mathrm{A}, \mathrm{a}}$ & $29,8 \pm 0,2^{\mathrm{A}, \mathrm{a}}$ & $29,7 \pm 0,2^{\mathrm{A}, \mathrm{a}}$ & $29,5 \pm 0,1^{\mathrm{A}, \mathrm{a}}$ & $29,4 \pm 0,2^{\mathrm{A}, \mathrm{a}}$ \\
\hline
\end{tabular}

Fonte: Própria autoria.

(1) $\mathrm{Cg}$ : concentração de gelatina

(2) tempo que amostra permaneceu à $5^{\circ} \mathrm{C}$ (isoterma)

Controle: formulação sem boldo; 50: formulação com 50g de extrato de boldo/100g de gelatina; 150: formulação com $150 \mathrm{~g}$ de extrato de boldo/100g de gelatina. A,B letras maiúsculas diferentes na mesma coluna indicam diferença significativa em diferentes concentrações de gelatina para o mesmo parâmetro.

a,b letras minúsculas diferentes na mesma linha indicam diferença significativa em diferentes concentrações de extrato de boldo-do-Chile para o mesmo parâmetro. 
O aumento na concentração de gelatina apresentou efeito sobre a entalpia de fusão ( $\Delta \mathrm{H} \mathrm{em} \mathrm{J/g} \mathrm{de} \mathrm{solução)} \mathrm{(Figura} \mathrm{30).} \mathrm{Ou} \mathrm{seja,} \mathrm{quanto} \mathrm{maior} \mathrm{a} \mathrm{concentração} \mathrm{de} \mathrm{gelatina,} \mathrm{maior}$ energia para dissociar as ligações na fusão do gel (SARBON; BADII; HOWELL, 2015). Os valores de $\Delta \mathrm{H}$ aumentaram linearmente, ficando entre 0,5 e 2,1J/g de solução, quando os valores de gelatina foram de 2 e $8 \mathrm{~g} / 100 \mathrm{~g}$ de $\mathrm{SF}$, respectivamente. Esse efeito também foi observado por Diaz-Caldéron et al. (2014) e Sarbon, Badii e Howell (2015).

Figura 30: Efeito da concentração de gelatina sobre a entalpia de fusão.

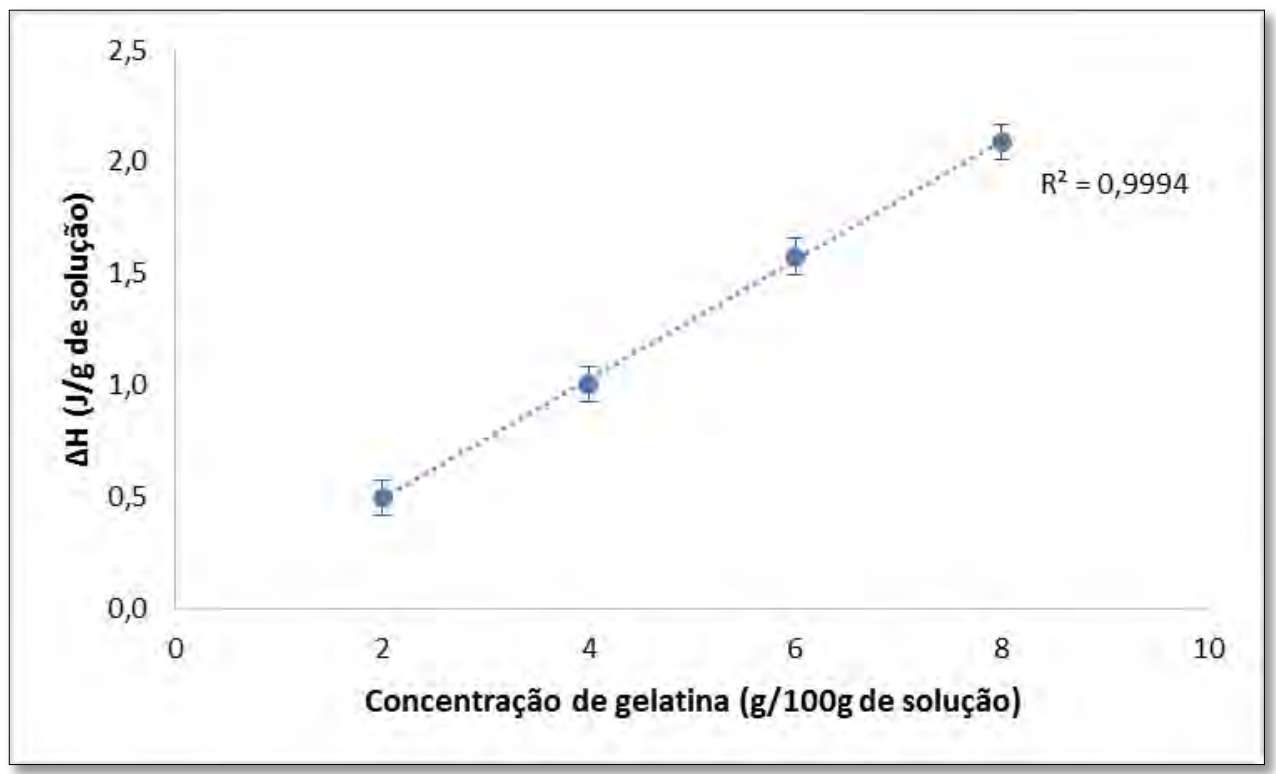

Fonte: Própria autoria.

Com isso, para avaliar o efeito da adição do extrato do boldo-do-Chile foi necessário eliminar o efeito da concentração de gelatina e expressar a entalpia em J/g de gelatina. Observou-se que quando as amostras permaneceram à $5^{\circ} \mathrm{C}$ por 30 minutos (Figura 31), não foi constatado nenhum efeito da adição do extrato de boldo sobre a entalpia de fusão ( $p>0,05$ ), sendo que o valor médio foi em torno de $24,5 \mathrm{~J} / \mathrm{g}$ de gelatina. 
Figura 31: Entalpia de fusão $(\Delta \mathrm{H})$ para as soluções de gelatina em diferentes concentrações para isotermas à $5^{\circ} \mathrm{C}$ durante 30 minutos.

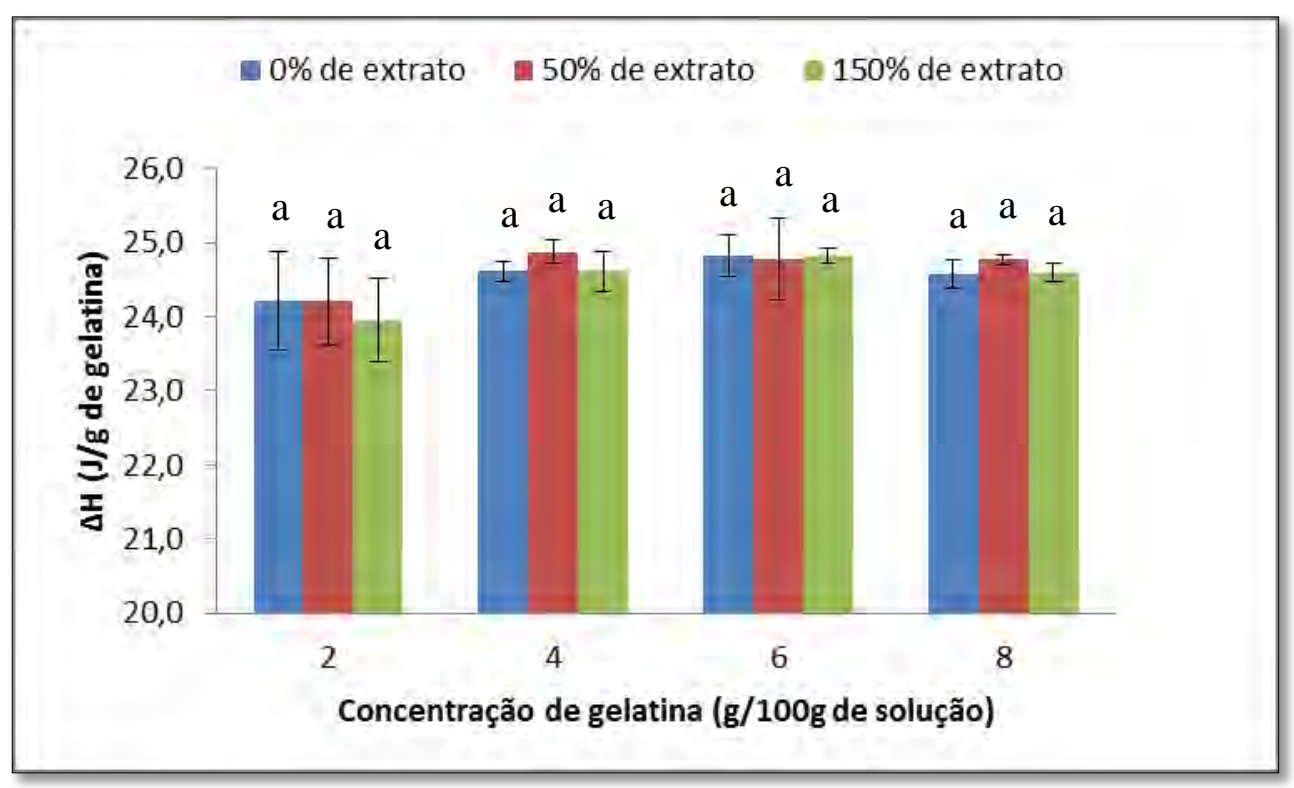

Fonte: Própria autoria.

- 0\% de extrato: Solução filmogênica sem extrato de boldo-do-Chile;

- 50\% de extrato: Solução filmogênica com $50 \mathrm{~g}$ de extrato de boldo-do-Chile/100g de gelatina; - $150 \%$ de extrato: Solução filmogênica com $150 \mathrm{~g}$ de extrato de boldo-do-Chile/100g de gelatina. a,b letras minúsculas diferentes para a mesma concentração de gelatina indicam diferença significativa para diferentes concentrações de extrato de boldo-do-Chile.

Quando se aumentou a duração da isoterma à $5^{\circ} \mathrm{C}$ para 60 minutos (Figura 32), foi possível verificar que a adição do extrato de boldo-do-Chile apresentou efeito sobre a entalpia de fusão $(\mathrm{p}<0,05)$. Quando se aumentou a quantidade de extrato para $150 \mathrm{~g}$ de extrato de boldo-do-Chile/100g de gelatina houve decréscimo da entalpia de fusão, esse comportamento foi observado para as concentrações de 2 a $6 \mathrm{~g}$ de gelatina/100g de solução, contudo o mesmo efeito não foi observado para a solução elaborada com $8 \mathrm{~g}$ de gelatina $/ 100 \mathrm{~g}$ de solução. 
Figura 32: Entalpia de fusão $(\Delta \mathrm{H})$ para as soluções de gelatina em várias concentrações passando por uma isoterma $5^{\circ} \mathrm{C}$ durante 60 minutos.

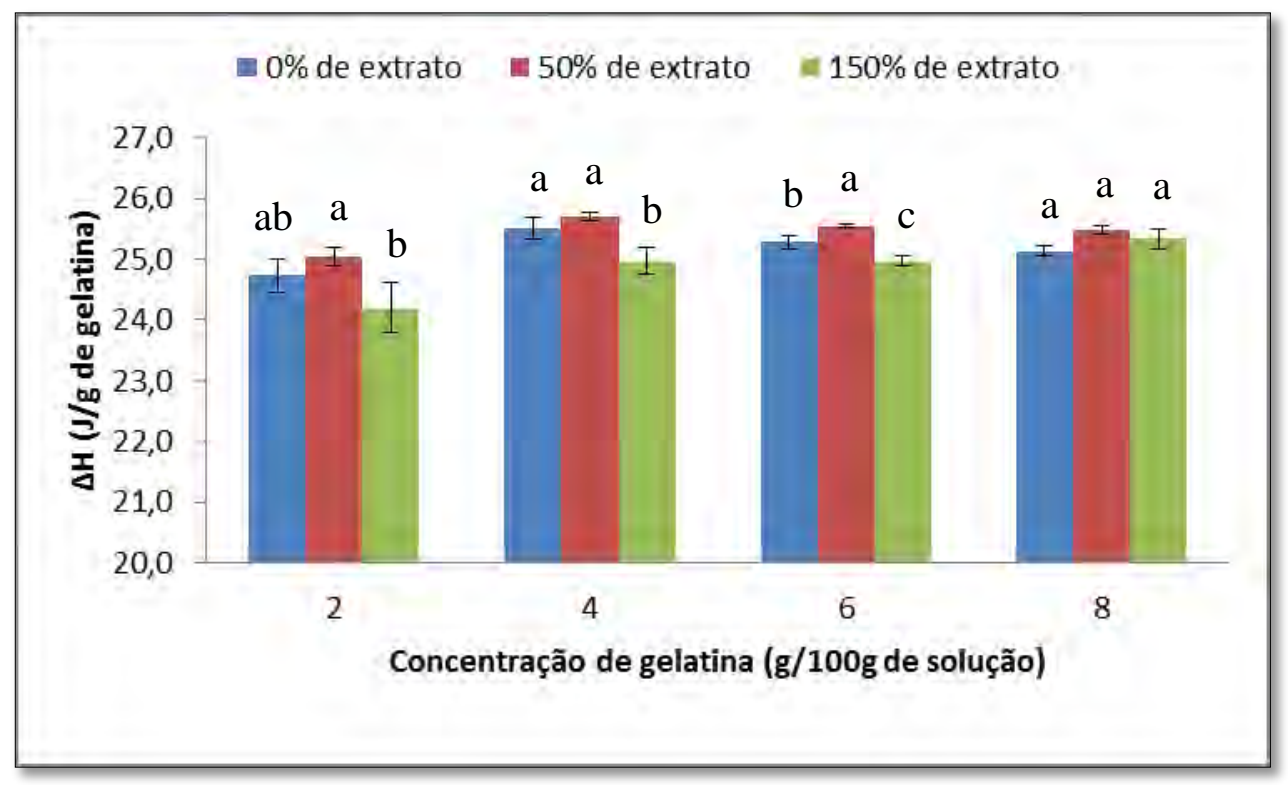

Fonte: Própria autoria.

- 0\% de extrato: Solução filmogênica sem extrato de boldo-do-Chile;

- 50\% de extrato: Solução filmogênica com $50 \mathrm{~g}$ de extrato de boldo-do-Chile/100g de gelatina; - $150 \%$ de extrato: Solução filmogênica com $150 \mathrm{~g}$ de extrato de boldo-do-Chile/100g de gelatina. a,b letras minúsculas diferentes para a mesma concentração de gelatina indicam diferença significativa para diferentes concentrações de extrato de boldo-do-Chile.

No caso da isoterma à 90 minutos (Figura 33), foi possível observar que, nas soluções com 4 e $6 \mathrm{~g}$ de gelatina/100g de solução, houve efeito estatístico significativo ( $p>0,05$ ), sobre o $\Delta \mathrm{H}$ quando adicionou-se $50 \mathrm{~g}$ de extrato/100g de gelatina. Esse efeito foi mais pronunciado para a solução com $6 \mathrm{~g}$ de gelatina/100g de solução. E como no caso da isoterma anterior, a adição de $150 \mathrm{~g}$ de extrato/100g de gelatina provocou uma diminuição na entalpia de fusão. Uma hipótese pode ser considerada nesse caso: as moléculas contidas no extrato se colocaram entre as cadeias peptídicas de gelatina impedindo a formação de alguma estrutura. A formulação que apresentou o maior valor de $\Delta \mathrm{H}$ foi aquela elaborada com $6 \mathrm{~g}$ de gelatina $/ 100 \mathrm{~g}$ de solução e $50 \mathrm{~g}$ de extrato/100g de gelatina $(\Delta \mathrm{H}=27,4 \pm 0,3 \mathrm{~J} / \mathrm{g}$ de gelatina). 
Figura 33: Entalpia de fusão $(\Delta \mathrm{H})$ para as soluções de gelatina em várias concentrações submetidas à uma isoterma à $5^{\circ} \mathrm{C}$ por 90 minutos.

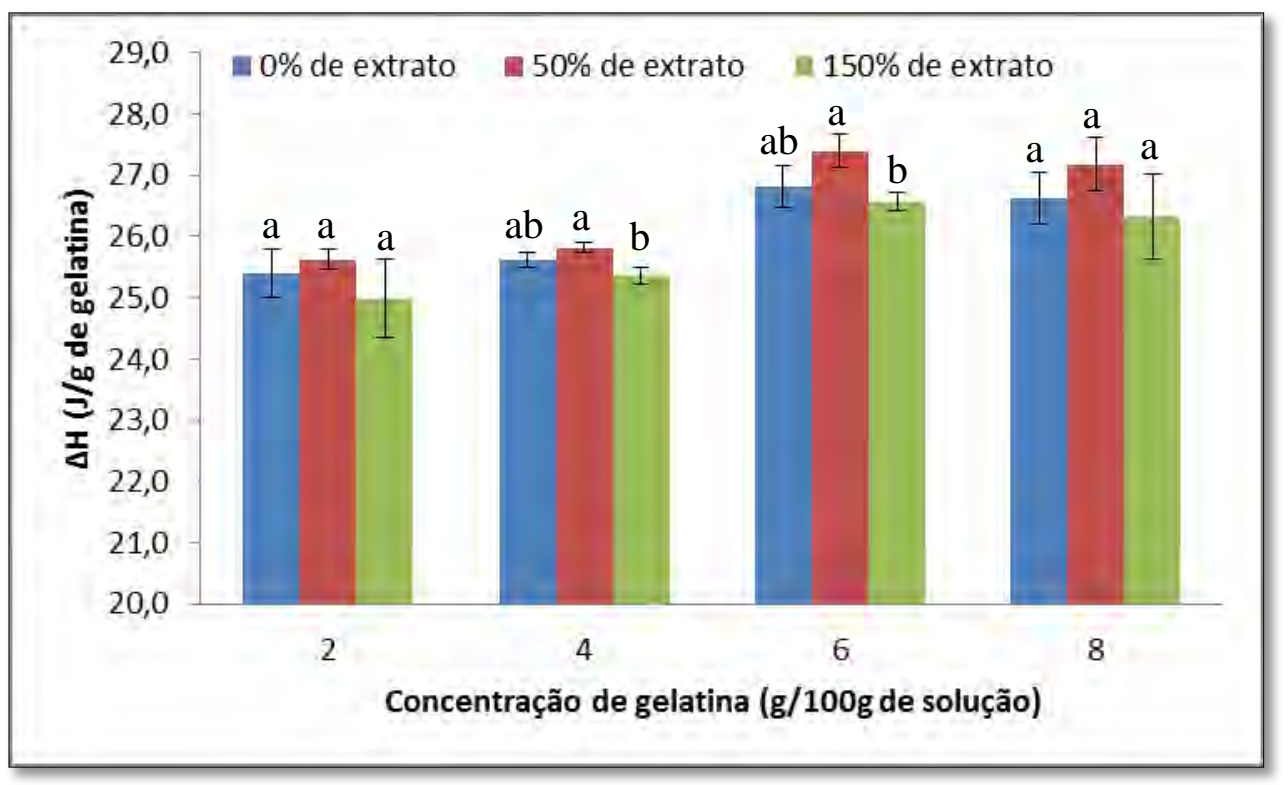

Fonte: Própria autoria.

- 0\% de extrato: Solução filmogênica sem extrato de boldo-do-Chile;

- 50\% de extrato: Solução filmogênica com $50 \mathrm{~g}$ de extrato de boldo-do-Chile/100g de gelatina; - $150 \%$ de extrato: Solução filmogênica com $150 \mathrm{~g}$ de extrato de boldo-do-Chile/100g de gelatina. a,b letras minúsculas diferentes para a mesma concentração de gelatina indicam diferença significativa para diferentes concentrações de extrato de boldo-do-Chile.

Avaliando o efeito da isoterma à $5^{\circ} \mathrm{C}$, utilizando-se os resultados da formulação com $6 \mathrm{~g}$ de gelatina/100g de solução (Figura 34), foi observado um efeito no tempo de duração da isoterma. Quanto maior a permanência da amostra à $5^{\circ} \mathrm{C}$, maior foi a energia necessária na fusão, independente da adição do extrato de boldo-do-Chile. Além disso, quando a quantidade de extrato de boldo-do-Chile adicionada foi de $50 \mathrm{~g} / 100 \mathrm{~g}$ de gelatina, a entalpia apresentou valores mais elevados para as isotermas de 60 e 90 minutos. 
Figura 34: Valores de $\Delta \mathrm{H}$ em função da duração da isoterma à $5^{\circ} \mathrm{C}$ para a amostra com $6 \mathrm{~g}$ de gelatina/100g de solução.

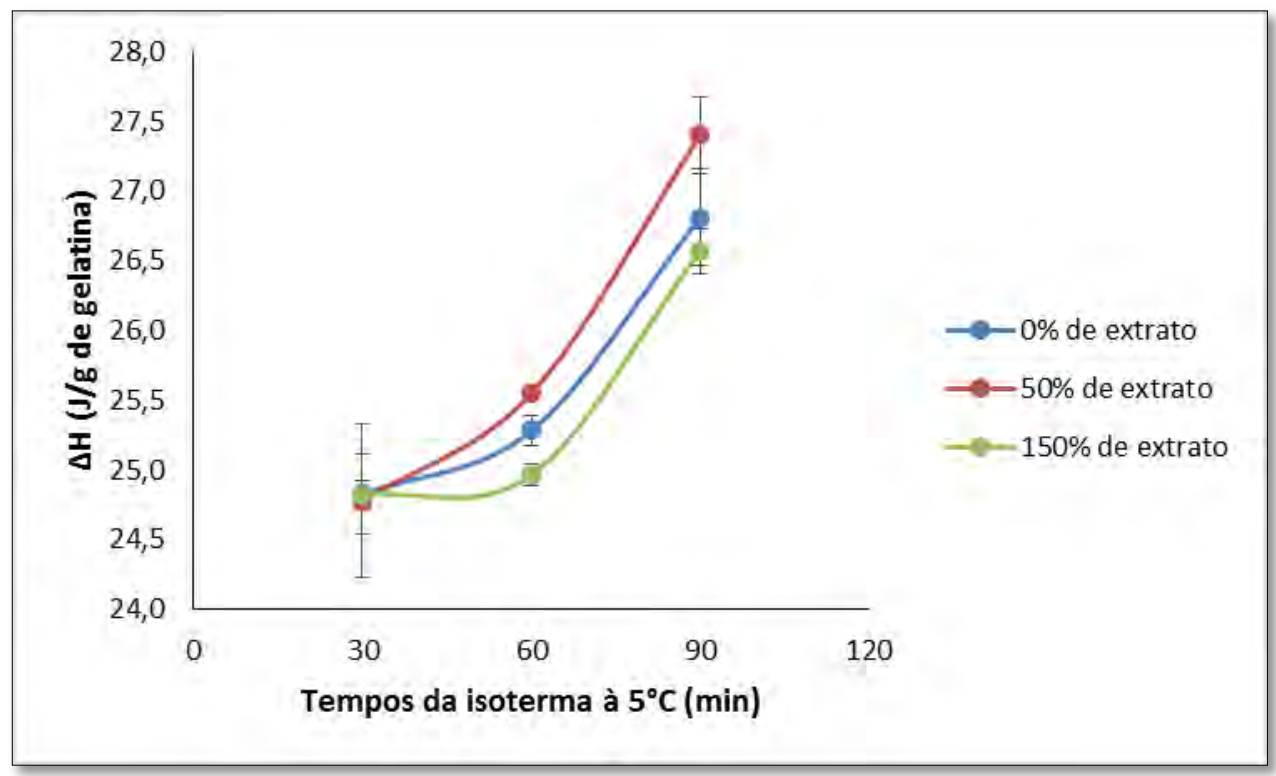

Fonte: Própria autoria

0\% de extrato: Solução filmogênica sem extrato de boldo-do-Chile;

- 50\% de extrato: Solução filmogênica com $50 \mathrm{~g}$ de extrato de boldo-do-Chile $/ 100 \mathrm{~g}$ de gelatina;

- $150 \%$ de extrato: Solução filmogênica com $150 \mathrm{~g}$ de extrato de boldo-do-Chile/100g de gelatina.

a,b letras minúsculas diferentes para a mesma concentração de gelatina indicam diferença significativa para diferentes concentrações de extrato de boldo-do-Chile.

Para melhor compreender o efeito da duração da isoterma sobre as propriedades térmicas das soluções foram lançados ensaios semelhantes aos já descritos. Entretanto nesse caso, a isoterma a $5^{\circ} \mathrm{C}$ teve duração de 240 minutos (Figura 35). Dessa maneira foi possível constatar que quando a amostra teve um tempo maior de contato com o extrato, a entalpia de fusão aumentou ( $\Delta \mathrm{H}=30,5 \pm 0,1 \mathrm{~J} / \mathrm{g}$ de gelatina) para a concentração de $50 \%$ de extrato. Entretanto, com a concentração de $150 \%$ de extrato, observou-se um decréscimo na entalpia, que passou a valores menores que os das soluções sem extrato, respectivamente, $25,8 \pm 0,3$ e $27,8 \pm 0,8 \mathrm{~J} / \mathrm{g}$ de gelatina. 
Figura 35: Entalpia de fusão $(\Delta \mathrm{H})$ para as soluções de gelatina com $6 \mathrm{~g}$ de gelatina/ $100 \mathrm{~g}$ de solução passando por uma isoterma à $5^{\circ} \mathrm{C}$ por 240 minutos

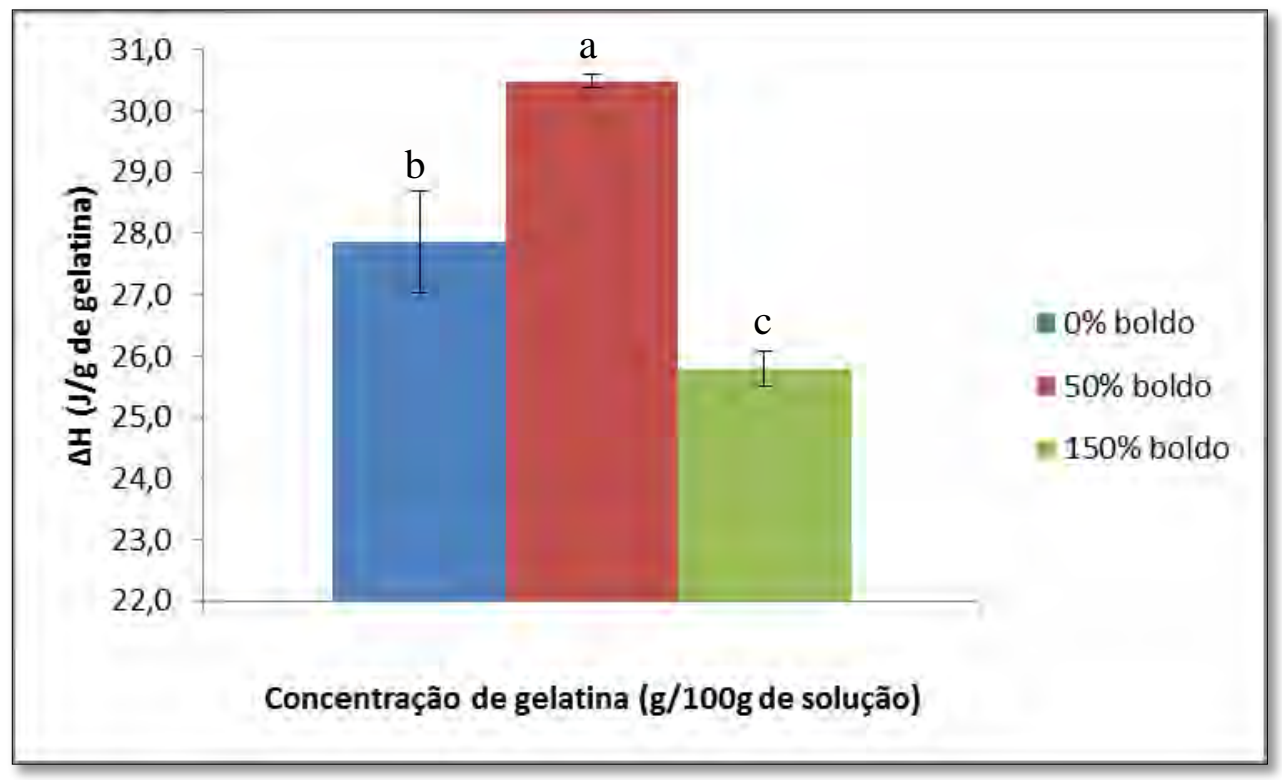

Fonte: Própria autoria.

- 0\% boldo: Solução filmogênica sem extrato de boldo-do-Chile;

- 50\% boldo: Solução filmogênica com $50 \mathrm{~g}$ de extrato de boldo-do-Chile/100g de gelatina;

- $150 \%$ boldo: Solução filmogênica com $150 \mathrm{~g}$ de extrato de boldo-do-Chile/100g de gelatina.

a,b letras minúsculas diferentes para a mesma concentração de gelatina indicam diferença significativa para diferentes concentrações de extrato de boldo-do-Chile.

O efeito do tempo da isoterma sobre os valores da entalpia de fusão não pode ser negligenciado (Figura 36). Sendo que a entalpia de fusão $(\Delta H)$ aumentou linearmente quanto maior foi o tempo em que a amostra permaneceu à $5^{\circ} \mathrm{C}$. $\mathrm{O}$ valor de $\Delta \mathrm{H}$ aumentou cerca de 12,5\% comparando um gel formado à 30 minutos e um formado à 240 minutos de duração de isoterma à $5^{\circ} \mathrm{C}$. Em geral os valores ficaram em torno de $24,8 \pm 0,3$ e $27,9 \pm 0,8 \mathrm{~J} / \mathrm{g}$ de gelatina, respectivamente.

Esses resultados corroboram com Tsereteli e Smirnova (1991), que encontraram que o tempo que a amostra permaneceu na temperatura de formação do gel permitiu a formação de ligações entre as cadeias de moléculas, aumentando a coesão da matriz e por consequência aumentando a entalpia de fusão do gel. 
Figura 36: Entalpia de fusão $(\Delta \mathrm{H})$ para as soluções de gelatina com $6 \mathrm{~g}$ de gelatina/100g de solução sem extrato avaliadas pelo tempo de isotermas diferentes.

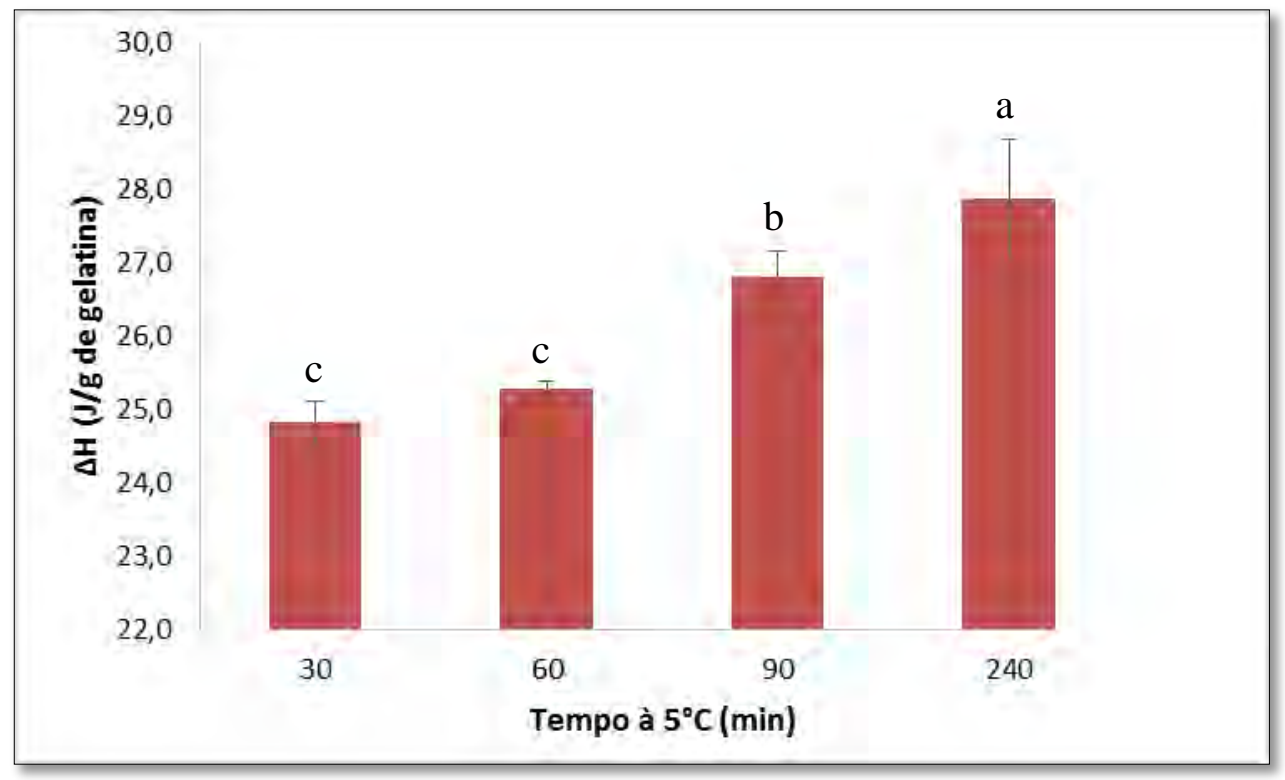

Fonte: Própria autoria.

a,b letras minúsculas diferentes para a diferentes tempos de isoterma à $5^{\circ} \mathrm{C}$ indicam diferença significativa. 


\subsection{Caracterização das soluções filmogênicas de colágeno}

Os testes reológicos de varredura de tensão para as soluções de colágeno mostraram que a variação do espaçamento ("gap") provocou variações tanto no módulo de armazenamento (G’) (Figura 37), como para o módulo de perda (G”) (Figura 38). Quando se variou o "gap" de 1000 para 1200mm, observou-se um aumento nos valores de G' e G", entretanto, ao alterar o "gap” para 1400mm os valores de G' e G” diminuíram, e seguiram oscilando, aumentando ("gap"=1600mm), diminuindo ("gap"=1800nm) e aumentando ("gap"=2000mm).

Figura 37: Resposta para módulo de armazenamento - G'(Pa) para a formulação de colágeno em diferentes "gap".

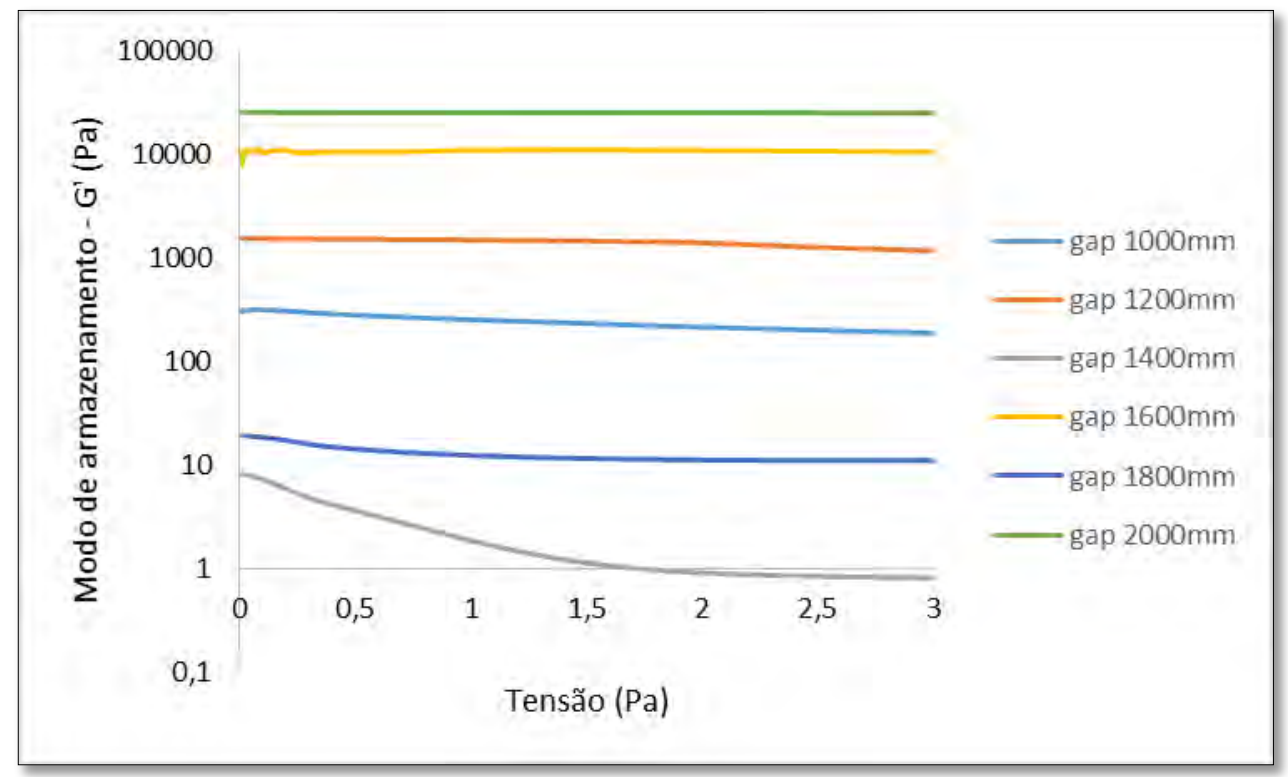

Fonte: Própria autoria.

De acordo com Albano, Franco e Telis (2014), as análieses reológicas devem ser realizadas em um intervalo de "gap" que não apresente efeito sobre G' e G', no caso das soluções de colágeno, não foi possível encontrar esse intervalo. Além disso, não se indica o emprego de grandes espaçamentos, acima de $2000 \mathrm{~mm}$, pois, a geometria pode perder o contato com a amostra gerando resultados incorretos. A solução de colágeno trata-se na realidade de uma dispersão, e sua já mencionada heterogeneidade (ver tópico 4.7) dificultou a realização das análises reológicas. 
Figura 38: Resposta para módulo de perda - G”(Pa) para a formulação de colágeno em diferentes "gap".

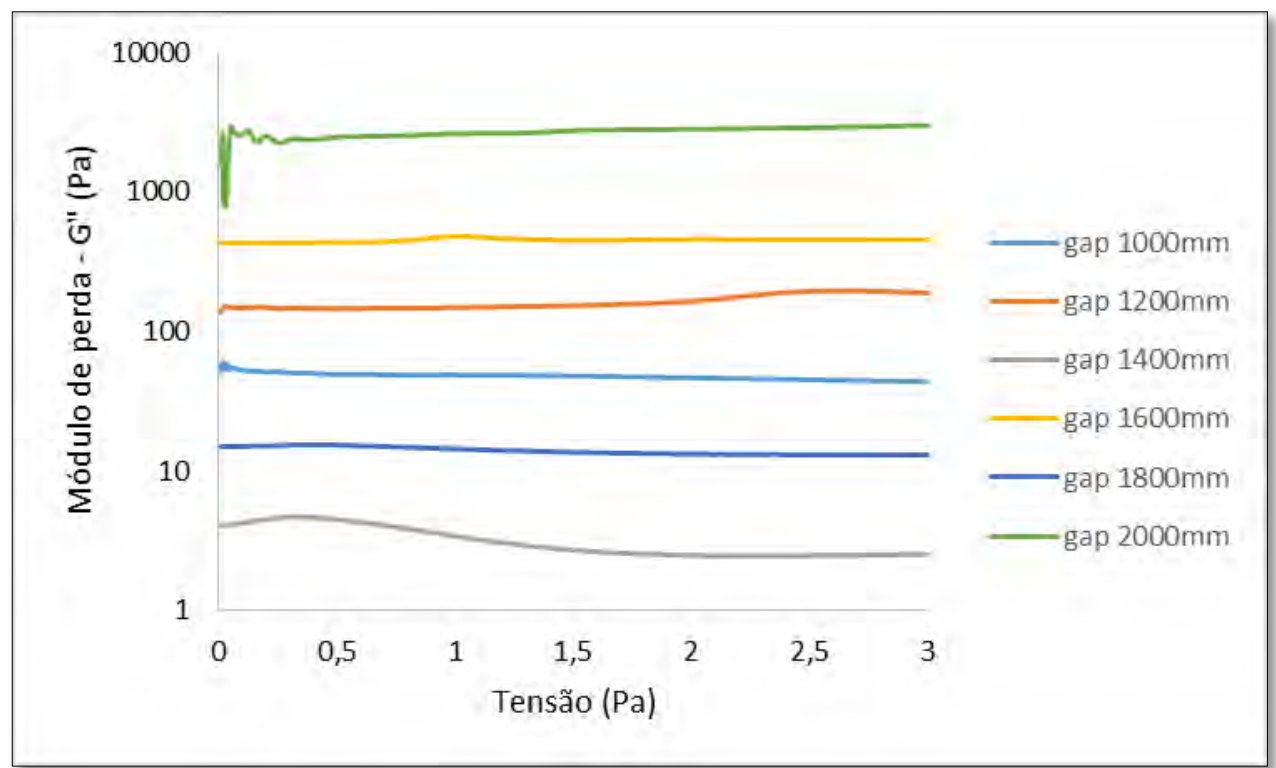

Fonte: Própria autoria. 


\subsection{Estudo das propriedades dos filmes de gelatina aditivados com extrato de boldo-do-Chile}

Os filmes de gelatina aditivados com extrato de boldo-do-Chile mostraram-se bastante homogêneos e transparentes não se observando diferença visual entre as superfícies de secagem e em contato com a placa. Observando-se que a adição do extrato implicou em um aumento da coloração amarela dos filmes (Figura 39).

Figura 39: Exemplos de filmes de gelatina adicionado de extrato de boldo-do-Chile

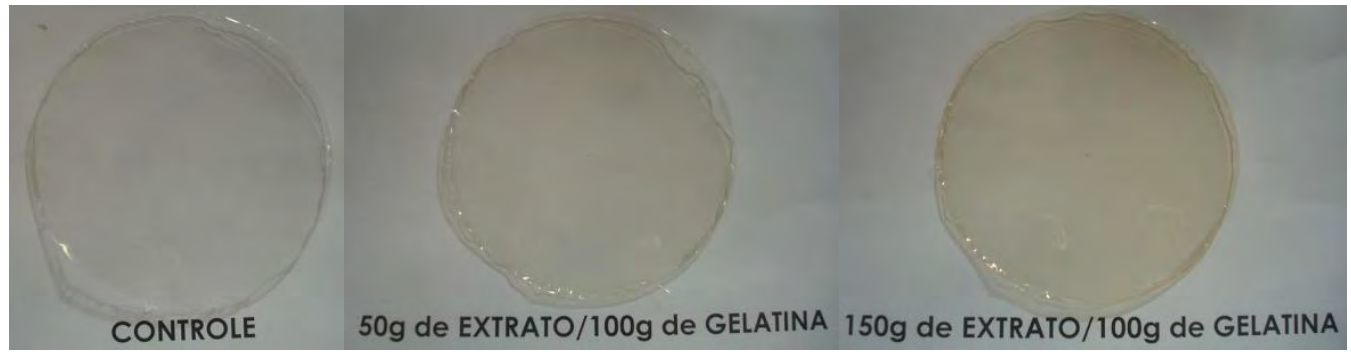

Fonte: Própria autoria

\subsubsection{Avaliação do efeito das concentrações do extrato de boldo-do-Chile e de gelatina nas propriedades mecânicas, solubilidade em água e propriedades óticas dos filmes}

Foram produzidos filmes com quatro concentrações de gelatina $(2,4,6$ e $8 \mathrm{~g}$ de gelatina/100g de SF), e, com três concentrações do extrato aquoso de boldo-do-Chile (produzido à $45^{\circ} \mathrm{C}$, baseado nas propriedades antioxidantes, ver tópico 5.2.2): 0, 50 e $150 \mathrm{~g}$ de extrato/100g de gelatina. Os filmes foram avaliados com relação às suas propriedades mecânicas (tração e perfuração), umidade, solubilidade e propriedades óticas (cor e opacidade). Todas as formulações foram produzidas em triplicata.

\subsubsection{Espessura dos filmes de gelatina}

Na produção dos filmes foi realizado um controle da massa de solução filmogênica aplicada nas placas, para se avaliar apenas o efeito da adição do extrato. Dessa forma, observou-se que a adição do extrato não provocou alteração na espessura dos filmes, ficando essa em torno de $0,083 \mathrm{~mm}$ (Tabela 14). 
Bitencourt el al. (2014), trabalhando com filmes de gelatina com extrato de cúrcuma, também não observaram efeito da adição do extrato na espessura dos filmes. Isso reforça a hipótese de que o extrato não influencia na espessura dos filmes ativos.

Tabela 14: Espessura dos filmes de gelatina adicionados de extrato de boldo em diferentes concentrações de macromolécula e extrato de boldo-do-Chile

\begin{tabular}{cccc}
\hline $\mathbf{C}_{\mathbf{G E L}}$ & Controle & Espessura $(\mathbf{m m})$ & \\
& $\mathbf{5 0}$ & $\mathbf{1 5 0}$ \\
\hline $\mathbf{2}$ & $0,082 \pm 0,005^{\mathrm{A}, \mathrm{a}}$ & $0,087 \pm 0,008^{\mathrm{A}, \mathrm{a}}$ & $0,085 \pm 0,002^{\mathrm{A}, \mathrm{a}}$ \\
$\mathbf{6}$ & $0,086 \pm 0,004^{\mathrm{A}, \mathrm{a}}$ & $0,085 \pm 0,086^{\mathrm{A}, \mathrm{a}}$ & $0,080 \pm 0,005^{\mathrm{A}, \mathrm{a}}$ \\
$\mathbf{8}$ & $0,083 \pm 0,006^{\mathrm{A}, \mathrm{a}}$ & $0,083 \pm 0,003^{\mathrm{A}, \mathrm{a}}$ & $0,080 \pm 0,007^{\mathrm{A}, \mathrm{a}}$ \\
\hline
\end{tabular}

Fonte: Própria autoria.

$\mathrm{C}_{\mathrm{GEL}}$ : Concentração de gelatina em g/100g de SF; Controle: formulação sem boldo; 50 : formulação com $50 \mathrm{~g}$ de extrato de boldo/100g de gelatina; 150: formulação com $150 \mathrm{~g}$ de extrato de boldo/ $100 \mathrm{~g}$ de gelatina.

A,B letras maiúsculas diferentes na mesma coluna indicam diferença significativa para a mesma concentração de extrato de boldo-do-Chile.

a,b letras minúsculas diferentes na mesma linha indicam diferença significativa para a mesma concentração de gelatina.

\subsubsection{Umidade e Solubilidade em água dos filmes de gelatina}

A umidade dos filmes de gelatina permaneceu inalterada frente a variação de concentração da macromolécula (Tabela 15) (p>0,05) e da adição do extrato de boldo-doChile ( $p>0,05$ ), sendo que os valores obtidos ficaram em torno de 13,5\%, característico de filmes à base de proteínas (ALVES et al., 2011; BITENCOURT et al., 2014; SOBRAL; HABITANTE, 2001; VANIN et al. 2005). Ou seja, nem a concentração de gelatina, nem a concentração de extrato alteraram a higroscopicidade dos filmes produzidos neste estudo, esta deve ser controlada pela própria gelatina com contribuição importante do plastificante glicerol. 
Tabela 15: Valores de umidade e solubilidade dos filmes de gelatina adicionados de extrato de boldo-do-Chile em diferentes concentrações de macromolécula e extrato.

\begin{tabular}{ccccccc}
\hline \multirow{2}{*}{ CGEL } & \multicolumn{3}{c}{ Umidade (\%) } & \multicolumn{3}{c}{ Solubilidade (\%) } \\
& Controle & $\mathbf{5 0}$ & $\mathbf{1 5 0}$ & Controle & $\mathbf{5 0}$ & $\mathbf{1 5 0}$ \\
\hline $\mathbf{2}$ & $13,3 \pm 1,0^{\mathrm{A}, \mathrm{a}}$ & $13,9 \pm 0,3^{\mathrm{A}, \mathrm{a}}$ & $12,8 \pm 1,1^{\mathrm{A}, \mathrm{a}}$ & $64,7 \pm 0,5^{\mathrm{A}, \mathrm{a}}$ & $63,8 \pm 2,0^{\mathrm{A}, \mathrm{a}}$ & $65,2 \pm 3,7^{\mathrm{A}, \mathrm{a}}$ \\
$\mathbf{4}$ & $13,2 \pm 1,0^{\mathrm{A}, \mathrm{a}}$ & $13,5 \pm 0,9^{\mathrm{A}, \mathrm{a}}$ & $14,1 \pm 1,6^{\mathrm{A}, \mathrm{a}}$ & $65,0 \pm 2,1^{\mathrm{A}, \mathrm{a}}$ & $64,5 \pm 3,1^{\mathrm{A}, \mathrm{a}}$ & $66,3 \pm 2,2^{\mathrm{A}, \mathrm{a}}$ \\
$\mathbf{6}$ & $12,7 \pm 0,8^{\mathrm{A}, \mathrm{a}}$ & $14,5 \pm 1,2^{\mathrm{A}, \mathrm{a}}$ & $12,7 \pm 0,7^{\mathrm{A}, \mathrm{a}}$ & $63,9 \pm 1,9^{\mathrm{A}, \mathrm{a}}$ & $64,1 \pm 0,3^{\mathrm{A}, \mathrm{a}}$ & $65,2 \pm 2,1^{\mathrm{A}, \mathrm{a}}$ \\
$\mathbf{8}$ & $13,4 \pm 0,9^{\mathrm{A}, \mathrm{a}}$ & $13,6 \pm 0,7^{\mathrm{A}, \mathrm{a}}$ & $12,3 \pm 0,5^{\mathrm{A}, \mathrm{a}}$ & $63,3 \pm 1,7^{\mathrm{A}, \mathrm{a}}$ & $64,2 \pm 1,8^{\mathrm{A}, \mathrm{a}}$ & $64,9 \pm 1,6^{\mathrm{A}, \mathrm{a}}$ \\
\hline
\end{tabular}

Fonte: Própria autoria

$\mathrm{C}_{\mathrm{GEL}}$ : Concentração de gelatina em g/100g de SF; Controle: formulação sem boldo; 50 : formulação com $50 \mathrm{~g}$ de extrato de boldo/100g de gelatina; 150: formulação com $150 \mathrm{~g}$ de extrato de boldo/100g de gelatina.

A,B letras maiúsculas diferentes na mesma coluna indicam diferença significativa para a mesma concentração de extrato de boldo-do-Chile e mesmo parâmetro.

a,b letras minúsculas diferentes na mesma linha indicam diferença significativa para a mesma concentração de gelatina e o mesmo parâmetro.

Comportamento semelhante foi observado para a solubilidade em água dos filmes de gelatina (Tabela 15). A variação da concentração de macromolécula não apresentou efeito significativo na solubilidade dos filmes ( $p>0,05$ ), nem a adição do extrato de boldo-do-Chile ( $p>0,05$ ). Observou-se que o valor médio ficou em torno de $64 \%$.

Bitencourt et al. (2014) trabalharam com filmes de gelatina adicionados de extrato etanólico de cúrcuma, e também observaram que não houve modificação estatisticamente significativa dos valores de umidade dos filmes, que variaram de 12,6 a 13,0\% (base úmida). Porém, esses autores demonstraram que houve diminuição significativa da solubilidade dos filmes, que variou de 40,0 a 35,8\%.

Hoque, Benjakul e Prodpran (2011) trabalharam com filmes de gelatina de peixe com adição de extratos de canela, alho e anis, e observaram uma redução na solubilidade dos filmes adicionados destes extratos. Esses autores atribuíram o efeito da adição do extrato, não somente à interação dos polifenóis contidos nos extratos, mas também ao tamanho das cadeias polipeptídicas da gelatina, afirmando que quanto menor o tamanho da cadeia maior seria a possibilidade de interação dos polifenóis. 


\subsubsection{Propriedades mecânicas por testes de tração}

Avaliando-se apenas o efeito da concentração da macromolécula (Tabela 16), observou-se que, de forma geral o aumento da concentração de gelatina implicou em um aumento significativo na tensão na ruptura $(\mathrm{p}<0,05)($ TR em MPa). Mas, a concentração do extrato não influenciou a tensão na ruptura dos filmes.

Com relação a concentração de gelatina, os resultados observados corroboraram com Jorge (2012), onde o aumento da concentração de gelatina aumentou a resistência à tração de filmes de gelatina suína plastificados com glicerol e produzidos por "spreading-casting". O autor variou a concentração de gelatina de 5 a 14\% e observou que a TR aumentou de 23,5 para 27,7MPa.

Com relação à elongação na ruptura (Tabela 16), foi possível perceber que o aumento na concentração de gelatina diminuiu a elongação na ruptura dos filmes $(p<0,05)$. EA adição do extrato de boldo-do-Chile não apresentou efeito sobre a ER. Avaliando-se os resultados obtidos para o módulo de elasticidade (Tabela 16), observou-se que não houve variação, independentemente da concentração de gelatina ou adição do extrato de boldo-do-Chile, ficando em torno de $4,5 \mathrm{MPa} / \%$.

Bitencourt et al. (2014) trabalharam com filmes de gelatina plastificados com sorbitol e adicionados de extrato etanólico de cúrcuma e constataram aumento na tensão na ruptura e elongação na ruptura dos filmes adicionados do extrato. Porém, não houve efeito sobre o módulo de elasticidade. Rattaya, Benjakul e Prodpran (2009) trabalharam com filmes de gelatina de peixe adicionados de extratos de algas marinhas, e observaram que a adição do extrato aumentou a tensão na ruptura e a elongação na ruptura desses filmes. Em ambos os casos, esses autores sugeriram que uma interação entre os compostos fenólicos do extrato e a matriz polimérica de gelatina seja a causa da alteração nas propriedades dos filmes.

Por outro lado, Li et al. (2014), analisando as propriedades mecânicas de filmes de gelatina de pele de peixe e glicerol adicionados de extratos de chá verde, de folhas de "gingko", de gengibre e de semente de uva, concluíram que a incorporação destes extratos, na maioria das vezes, causou uma diminuição significativa na tensão e elongação na ruptura e, raramente, não interferiu significativamente em tais resultados. Esses autores sugerem que os compostos fenólicos dos extratos possam ter formado ligações de hidrogênio e/ou covalentes com a gelatina, enfraquecendo a interação proteína-proteína da matriz polimérica.

Gómez-Estaca et al (2009b) trabalhando com filmes de gelatina de peixe adicionados de extrato de borragem (Borago officinalis) observaram que a adição do extrato diminuiu 
tanto a tensão na ruptura, como a elongação na ruptura. Eles atribuíram esse efeito à presença de compostos fenólicos que impediram a formação da rede da gelatina.

Dessa forma, pode-se supor que não houve uma interação suficientemente forte dos componentes polifenólicos dos extratos de folhas de boldo-do-Chile com a matriz polimérica do filme de gelatina e glicerol, já que a adição dos extratos não provocou efeito de aumento nem diminuição das propriedades de tração dos filmes. 
Tabela 16: Valores da tensão na ruptura (TR), elongação na ruptura (ER) e módulo de elasticidade (ME) dos filmes de gelatina adicionados de extrato de boldo em diferentes concentrações de macromolécula e extrato.

\begin{tabular}{|c|c|c|c|c|c|c|c|c|c|}
\hline \multirow{2}{*}{ CGel } & \multicolumn{3}{|c|}{ TR (MPa) } & \multicolumn{3}{|c|}{ ER (\%) } & \multicolumn{3}{|c|}{ ME (MPa/\%) } \\
\hline & Controle & 50 & 150 & Controle & 50 & 150 & Controle & 50 & 150 \\
\hline 2 & $8,7 \pm 1,0^{\mathrm{D}, \mathrm{a}}$ & $8,2 \pm 0,8^{\mathrm{D}, \mathrm{a}}$ & $8,1 \pm 0,7^{\mathrm{D}, \mathrm{a}}$ & $93,7 \pm 7,7^{\mathrm{A}, \mathrm{a}}$ & $104,2 \pm 7,2^{\mathrm{A}, \mathrm{a}}$ & $108,0 \pm 7,4^{\mathrm{A}, \mathrm{a}}$ & $4,4 \pm 0,6^{\mathrm{A}, \mathrm{a}}$ & $4,4 \pm 0,3^{\mathrm{A}, \mathrm{a}}$ & $4,0 \pm 0,2^{\mathrm{A}, \mathrm{a}}$ \\
\hline 4 & $13,4 \pm 1,2^{\mathrm{C}, \mathrm{a}}$ & $13,0 \pm 1,1^{\mathrm{C}, \mathrm{a}}$ & $13,3 \pm 1,0^{\mathrm{C}, \mathrm{a}}$ & $74,4 \pm 5,1^{\mathrm{B}, \mathrm{a}}$ & $76,4 \pm 9,0^{\mathrm{B}, \mathrm{a}}$ & $78,8 \pm 10,0^{\mathrm{B}, \mathrm{a}}$ & $4,4 \pm 0,6^{\mathrm{A}, \mathrm{a}}$ & $4,4 \pm 0,3^{\mathrm{A}, \mathrm{a}}$ & $4,2 \pm 0,5^{\mathrm{A}, \mathrm{a}}$ \\
\hline 6 & $18,9 \pm 1,2^{\mathrm{B}, \mathrm{a}}$ & $17,9 \pm 1,1^{\mathrm{B}, \mathrm{a}}$ & $17,3 \pm 2,2^{\mathrm{B}, \mathrm{a}}$ & $57,7 \pm 6,0^{\mathrm{C}, \mathrm{a}}$ & $57,3 \pm 6,8^{\mathrm{C}, \mathrm{a}}$ & $58,9 \pm 6,7^{\mathrm{B}, \mathrm{a}}$ & $4,5 \pm 0,5^{\mathrm{A}, \mathrm{a}}$ & $4,6 \pm 0,5^{\mathrm{A}, \mathrm{a}}$ & $4,3 \pm 0,4^{\mathrm{A}, \mathrm{a}}$ \\
\hline 8 & $23,6 \pm 1,2^{\mathrm{A}, \mathrm{a}}$ & $22,3 \pm 2,1^{\mathrm{A}, \mathrm{a}}$ & $23,6 \pm 1,5^{\mathrm{A}, \mathrm{a}}$ & $36,1 \pm 5,3^{\mathrm{D}, \mathrm{a}}$ & $42,6 \pm 4,7^{\mathrm{C}, \mathrm{a}}$ & $34,6 \pm 5,7^{\mathrm{C}, \mathrm{a}}$ & $4,2 \pm 0,4^{\mathrm{A}, \mathrm{a}}$ & $4,0 \pm 0,2^{\mathrm{A}, \mathrm{a}}$ & $4,3 \pm 0,3^{\mathrm{A}, \mathrm{a}}$ \\
\hline
\end{tabular}

Fonte: Própria autoria.

$\mathrm{C}_{\mathrm{GEL}}$ : Concentração de gelatina em g/100g de SF; Controle: formulação sem boldo; 50: formulação com 50g de extrato de boldo/100g de gelatina; 150 : formulação com $150 \mathrm{~g}$ de extrato de boldo/100g de gelatina.

A,B letras maiúsculas diferentes na mesma coluna indicam diferença significativa para o mesmo parâmetro.

a,b letras minúsculas diferentes na mesma linha indicam diferença significativa para o mesmo parâmetro. 
5.5.1.4 Propriedades mecânicas por testes de perfuração

Os resultados dos testes de perfuração (Tabela 17) dos filmes com extrato de boldodo-Chile apresentaram um comportamento semelhante aos resultados obtidos para o teste de tração (Tabela 16). A força na perfuração (FP) variou entre 10,3 e 27,9N, para filmes com $2 \mathrm{~g}$ de gelatina/100g de SF e $150 \mathrm{~g}$ de extrato de boldo-do-Chile, e filmes com $8 \mathrm{~g}$ de gelatina/100g de SF sem adição de extrato, respectivamente.

Além disso, observou-se que apenas a variação na concentração de gelatina apresentou efeito sobre a força na perfuração $(p<0,05)$ sendo que quando se aumentou a concentração de gelatina aumentou-se a resistência à perfuração. A concentração do extrato de boldo-do-Chile não apresentou efeito sobre esta propriedade $(p>0,05)$.

Tabela 17: Valores da força na perfuração (FP), deformação na perfuração (DP) dos filmes de gelatina adicionados de extrato de boldo em diferentes concentrações de macromolécula e extrato.

\begin{tabular}{ccccccc}
\hline \multirow{2}{*}{ CGEL } & \multicolumn{3}{c}{ FP $(\mathbf{N})$} & & \multicolumn{3}{c}{ DP $(\%)$} \\
& Controle & $\mathbf{5 0}$ & $\mathbf{1 5 0}$ & Controle & $\mathbf{5 0}$ & $\mathbf{1 5 0}$ \\
\hline $\mathbf{2}$ & $10,8 \pm 0,4^{\mathrm{C}, \mathrm{a}}$ & $10,8 \pm 0,9^{\mathrm{C}, \mathrm{a}}$ & $10,3 \pm 0,8^{\mathrm{D}, \mathrm{a}}$ & $10,4 \pm 0,3^{\mathrm{A}, \mathrm{b}}$ & $11,0 \pm 0,3^{\mathrm{A}, \mathrm{ab}}$ & $11,2 \pm 0,3^{\mathrm{A}, \mathrm{a}}$ \\
$\mathbf{4}$ & $17,4 \pm 1,1^{\mathrm{B}, \mathrm{a}}$ & $17,2 \pm 0,8^{\mathrm{B}, \mathrm{a}}$ & $16,9 \pm 1,1^{\mathrm{C}, \mathrm{a}}$ & $7,5 \pm 0,3^{\mathrm{B}, \mathrm{a}}$ & $7,6 \pm 0,4^{\mathrm{B}, \mathrm{a}}$ & $7,9 \pm 0,3^{\mathrm{B}, \mathrm{a}}$ \\
$\mathbf{6}$ & $25,3 \pm 1,3^{\mathrm{A}, \mathrm{a}}$ & $23,5 \pm 1,3^{\mathrm{A}, \mathrm{a}}$ & $22,5 \pm 2,1^{\mathrm{B}, \mathrm{a}}$ & $5,6 \pm 0,3^{\mathrm{C}, \mathrm{a}}$ & $5,7 \pm 0,4^{\mathrm{C}, \mathrm{a}}$ & $5,9 \pm 0,2^{\mathrm{C}, \mathrm{a}}$ \\
$\mathbf{8}$ & $27,9 \pm 0,9^{\mathrm{A}, \mathrm{a}}$ & $26,5 \pm 0,9^{\mathrm{A}, \mathrm{a}}$ & $26,4 \pm 0,6^{\mathrm{A}, \mathrm{a}}$ & $3,8 \pm 0,2^{\mathrm{D}, \mathrm{a}}$ & $4,0 \pm 0,1^{\mathrm{D}, \mathrm{a}}$ & $4,1 \pm 0,2^{\mathrm{D}, \mathrm{a}}$ \\
\hline
\end{tabular}

Fonte: Própria autoria.

$\mathrm{C}_{\mathrm{GEL}}$ : Concentração de gelatina em g/100g de SF; Controle: formulação sem boldo; 50 : formulação com $50 \mathrm{~g}$ de extrato de boldo/100g de gelatina; 150 : formulação com $150 \mathrm{~g}$ de extrato de boldo/100g de gelatina.

A,B letras maiúsculas diferentes na mesma coluna indicam diferença significativa para o mesmo parâmetro.

a,b letras minúsculas diferentes na mesma linha indicam diferença significativa para o mesmo parâmetro.

Com relação à deformação na perfuração, observou-se um efeito inverso ao da força na perfuração $(p<0,05)$. Ou seja, o aumento na concentração de gelatina implicou em uma diminuição na elongação na perfuração. Isso pode ser atribuído ao fato de que o aumento na concentração de macromolécula deixou os filmes mais resistentes, e, portanto, menos deformáveis (CARVALHO; GROSSO, 2004). Observou-se efeito estatístico significativo 
$(\mathrm{p}<0,05)$ da concentração do extrato somente para $2 \mathrm{~g}$ de gelatina/100g de $\mathrm{SF}$, onde a adição do extrato deixou os filmes mais deformáveis.

Gómez-Guillén et al. (2007), trabalhando com filmes de gelatina de atum adicionados de extrato de murta (Ugni molinae Turcz), observaram que a adição do extrato provocou uma diminuição tanto na força na perfuração, como na deformação na perfuração. Esses autores correlacionaram esse efeito negativo sobre as propriedades dos filmes como sendo oriundo da não formação de ligações hidrogênio-hidrogênio.

Desse modo, sugere-se que o boldo-do-Chile não foi capaz de alterar as propriedades mecânicas dos filmes produzidos com gelatina, e isso provavelmente está correlacionado à não interação dos compostos fenólicos presentes no extrato com a moléculas de gelatina.

\subsubsection{Cor e opacidade}

Os ensaios de cor e opacidade mostraram, de forma geral que a adição do extrato de boldo-do-Chile influenciou os parâmetros de cor L*, a* e b* (Tabela 18). Entretanto a concentração de gelatina não apresentou efeito sobre esses parâmetros. Observou-se que, embora tenha havido efeito estatístico significativo $(\mathrm{p}<0,05)$, o parâmetro $\mathrm{L}^{*}$, que se relaciona à luminosidade apresentou valores muito próximos para todas as concentrações, seja de gelatina ou de extrato de boldo. O valor ficou em torno de 90,0, ou seja, o filme apresentou tonalidade muito clara.

Com relação ao parâmetro $\mathrm{a}^{*}$, que varia do verde (-a*) ao vermelho ( $\left.\mathrm{a}^{*}\right)$, os filmes, ainda que sem a presença do extrato de boldo, mostraram-se levemente esverdeados. Nesse caso, de maneira geral, não se observou efeito da concentração de macromoléculas ( $p>0,05$. Já adição do extrato apresentou efeito significativo $(p<0,05)$, fazendo com que os filmes tendessem a sua coloração mais para o extremo verde, isso se comprova por valores mais negativos $(-0,8$ à $-1,5)$ quanto maior a adição de extrato. 
Tabela 18: Resultados dos parâmetros $\mathrm{L}^{*}, \mathrm{a}^{*}$ e $\mathrm{b}^{*}$ de filmes produzidos em diferentes concentrações de gelatina e extratos de boldo-do-Chile

\begin{tabular}{|c|c|c|c|c|c|c|c|c|c|}
\hline \multirow{2}{*}{ CGel } & \multicolumn{3}{|c|}{$\mathbf{L}^{*}$} & \multicolumn{3}{|c|}{$\mathbf{a}^{*}$} & \multicolumn{3}{|c|}{$\mathbf{b}^{*}$} \\
\hline & Controle & 50 & 150 & Controle & 50 & 150 & Controle & 50 & 150 \\
\hline 2 & $91,5 \pm 0,6^{\mathrm{A}, \mathrm{a}}$ & $91,0 \pm 0,6^{\mathrm{A}, \mathrm{a}}$ & $89,1 \pm 0,1^{\mathrm{A}, \mathrm{b}}$ & $-0,8 \pm 0,0^{\mathrm{A}, \mathrm{a}}$ & $-1,0 \pm 0,1^{\mathrm{B}, \mathrm{a}}$ & $-1,5 \pm 0,1^{\mathrm{A}, \mathrm{b}}$ & $2,6 \pm 0,0^{\mathrm{A}, \mathrm{c}}$ & $5,1 \pm 0,5^{\mathrm{A}, \mathrm{b}}$ & $10,0 \pm 0,2^{\mathrm{A}, \mathrm{a}}$ \\
\hline 4 & $91,1 \pm 0,0^{\mathrm{A}, \mathrm{a}}$ & $91,0 \pm 0,6^{\mathrm{A}, \mathrm{a}}$ & $89,7 \pm 0,3^{\mathrm{A}, \mathrm{b}}$ & $-0,8 \pm 0,0^{\mathrm{A}, \mathrm{a}}$ & $-0,9 \pm 0,1^{\mathrm{B}, \mathrm{a}}$ & $-1,5 \pm 0,2^{\mathrm{A}, \mathrm{b}}$ & $2,6 \pm 0,1^{\mathrm{A}, \mathrm{c}}$ & $4,9 \pm 0,1^{\mathrm{A}, \mathrm{b}}$ & $9,3 \pm 0,5^{\mathrm{A}, \mathrm{a}}$ \\
\hline 6 & $91,5 \pm 0,3^{\mathrm{A}, \mathrm{a}}$ & $91,5 \pm 0,2^{\mathrm{A}, \mathrm{a}}$ & $89,9 \pm 1,2^{\mathrm{A}, \mathrm{b}}$ & $-0,8 \pm 0,0^{\mathrm{A}, \mathrm{a}}$ & $-1,0 \pm 0,1^{\mathrm{B}, \mathrm{a}}$ & $-1,4 \pm 0,2^{\mathrm{A}, \mathrm{b}}$ & $2,7 \pm 0,2^{\mathrm{A}, \mathrm{c}}$ & $5,4 \pm 0,3^{\mathrm{A}, \mathrm{b}}$ & $9,2 \pm 1,3^{\mathrm{A}, \mathrm{a}}$ \\
\hline 8 & $91,2 \pm 0,0^{\mathrm{A}, \mathrm{a}}$ & $91,5 \pm 0,2^{\mathrm{A}, \mathrm{a}}$ & $89,9 \pm 1,2^{\mathrm{A}, \mathrm{b}}$ & $-0,8 \pm 0,0^{\mathrm{A}, \mathrm{a}}$ & $-1,4 \pm 0,2^{\mathrm{A}, \mathrm{a}}$ & $-1,5 \pm 0,0^{\mathrm{A}, \mathrm{b}}$ & $2,5 \pm 0,1^{\mathrm{A}, \mathrm{c}}$ & $4,9 \pm 0,3^{\mathrm{A}, \mathrm{b}}$ & $8,7 \pm 0,3^{\mathrm{A}, \mathrm{a}}$ \\
\hline
\end{tabular}

Fonte: Própria autoria.

$\mathrm{C}_{\mathrm{GEL}}$ : Concentração de gelatina em g/100g de SF; Controle: formulação sem boldo; 50: formulação com 50g de extrato de boldo/100g de gelatina; 150 : formulação com $150 \mathrm{~g}$ de extrato de boldo/100g de gelatina.

A,B letras maiúsculas diferentes na mesma coluna indicam diferença significativa para o mesmo parâmetro.

a,b letras minúsculas diferentes na mesma linha indicam diferença significativa para o mesmo parâmetro. 
Comportamento semelhante foi observado para $o b^{*}$, que representa a variação entre azul (-b*) e amarelo (+b*). Não houve efeito significativo da variação da concentração de gelatina ( $p>0,05)$. Sendo que a alteração de cor ocorrida nos filmes foi atribuída a concentração do extrato. A coloração predominante foi amarelada, $\left(2,5 \leq \mathrm{b}^{*} \leq 10,0\right)$.

Para o cálculo da diferença total de cor $\left(\Delta \mathrm{E}^{*}\right)$ (Tabela 19) utilizou-se um padrão de valores $\mathrm{L}_{0} *=94,8, \mathrm{a}_{0} *=-0,8 \mathrm{e} \mathrm{b}_{0}{ }^{*}=2,1$, relativo à placa branca utilizada nos testes. A variação da concentração de macromoléculas mais uma vez não apresentou efeito estatístico significativo ( $p>0,05)$. Porém, a concentração de extrato de-boldo-do-Chile implicou em um aumento $(\mathrm{p}<0,05)$ dos valores de $\Delta \mathrm{E}^{*}$, sendo que quanto maior a concentração do extrato, maior o valor de $\Delta \mathrm{E}^{*}$, ou seja, os filmes tornaram-se mais coloridos. De acordo com Rattaya, Benjakul e Prodpran (2009), a alteração de cor nos filmes pela adição do extrato pode ser atribuída aos pigmentos contidos no extrato de boldo-do-Chile.

Tabela 19: Valores de diferença total de cor $\left(\Delta \mathrm{E}^{*}\right)$ e opacidade para os filmes produzidos em diferentes concentrações de gelatina e extrato de boldo-do-Chile.

\begin{tabular}{ccccccc}
\hline \multirow{2}{*}{$\mathbf{C}_{\text {GEL }}$} & \multicolumn{3}{c}{$\boldsymbol{\Delta \mathbf { E } ^ { * }}$} & & \multicolumn{3}{c}{ Opacidade } \\
& Controle & $\mathbf{5 0}$ & $\mathbf{1 5 0}$ & Controle & $\mathbf{5 0}$ & $\mathbf{1 5 0}$ \\
\hline $\mathbf{2}$ & $3,3 \pm 0,2^{\mathrm{A}, \mathrm{c}}$ & $5,1 \pm 0,2^{\mathrm{A}, \mathrm{b}}$ & $9,7 \pm 0,2^{\mathrm{A}, \mathrm{a}}$ & $0,7 \pm 0,5^{\mathrm{A}, \mathrm{a}}$ & $0,2 \pm 0,1^{\mathrm{A}, \mathrm{a}}$ & $0,6 \pm 0,2^{\mathrm{A}, \mathrm{a}}$ \\
$\mathbf{4}$ & $3,8 \pm 0,0^{\mathrm{A}, \mathrm{c}}$ & $5,1 \pm 0,5^{\mathrm{A}, \mathrm{b}}$ & $8,9 \pm 0,2^{\mathrm{A}, \mathrm{a}}$ & $0,2 \pm 0,0^{\mathrm{A}, \mathrm{a}}$ & $0,4 \pm 0,3^{\mathrm{A}, \mathrm{a}}$ & $0,6 \pm 0,1^{\mathrm{A}, \mathrm{a}}$ \\
$\mathbf{6}$ & $3,4 \pm 0,2^{\mathrm{A}, \mathrm{b}}$ & $4,7 \pm 0,3^{\mathrm{A}, \mathrm{b}}$ & $8,7 \pm 1,8^{\mathrm{A}, \mathrm{a}}$ & $0,3 \pm 0,4^{\mathrm{A}, \mathrm{a}}$ & $0,5 \pm 0,4^{\mathrm{A}, \mathrm{a}}$ & $0,5 \pm 0,4^{\mathrm{A}, \mathrm{a}}$ \\
$\mathbf{8}$ & $3,7 \pm 0,0^{\mathrm{A}, \mathrm{b}}$ & $4,3 \pm 0,1^{\mathrm{A}, \mathrm{b}}$ & $8,3 \pm 0,5^{\mathrm{A}, \mathrm{a}}$ & $0,4 \pm 0,3^{\mathrm{A}, \mathrm{a}}$ & $0,5 \pm 0,4^{\mathrm{A}, \mathrm{a}}$ & $0,3 \pm 0,1^{\mathrm{A}, \mathrm{a}}$ \\
\hline
\end{tabular}

Fonte: Própria autoria

$\mathrm{C}_{\mathrm{GEL}}$ : Concentração de gelatina em g/100g de SF; Controle: formulação sem boldo; 50 : formulação com $50 \mathrm{~g}$ de extrato de boldo/100g de gelatina; 150 : formulação com $150 \mathrm{~g}$ de extrato de boldo/ $100 \mathrm{~g}$ de gelatina.

A,B letras maiúsculas diferentes na mesma coluna indicam diferença significativa para o mesmo parâmetro.

a,b letras minúsculas diferentes na mesma linha indicam diferença significativa para o mesmo parâmetro.

A opacidade dos filmes não sofreu efeito nem na concentração de gelatina $(p>0,05)$ e nem da concentração do extrato de boldo-do-Chile, sendo que esses valores ficaram em torno de 0,5, ou seja, os filmes continuaram muito transparentes. Bitencourt et al. (2014) trabalharam com filmes de gelatina adicionados de extrato etanólico de cúrcuma e observaram que a adição do extrato também afetou os parâmetros de cor L*, a* e b*, com importante de aumento da cor amarela nos filmes. Hoque, Benjakul e Prodpran (2011) 
trabalharam com filmes de gelatina de peixe adicionados de extratos de anis, canela e cravo, e também observaram efeitos sobre os parâmetros de cor ( $L^{*}, a^{*}$ e b*). Rattaya, Benjakul e Prodpran (2009) estudaram a adição de extratos de algas marinhas em filmes de gelatina de peixe e obtiveram diferenças nos parâmetros de cor $\left(\mathrm{L}^{*}, \mathrm{a}^{*} \mathrm{e} \mathrm{b}^{*}\right)$, nesse caso, os filmes tenderam à cor verde, que era a cor dos extratos produzidos.

A opacidade de filmes de gelatina da formulação controle, sem adição de extrato, foi semelhante aos resultados obtidos por Vanin et al. (2005), trabalhando com filmes de gelatina plastificados com glicerol, que determinaram uma opacidade em torno de 0,4.

Entretanto, filmes de gelatina de peixe adicionados de extratos aquosos de orégano, alecrim e apresentaram aumento nos valores de opacidade. $\mathrm{O}$ aumento no valor de $\mathrm{Y}$ foi atribuído à interação dos compostos fenólicos com a gelatina, onde a estabilização das cadeias polipeptídicas teria deixado os filmes mais opacos (GÓMEZ-ESTACA et al., 2009b,c). Ainda assim, os filmes produzidos por estes autores foram bastantes transparentes $(\mathrm{Y} \rightarrow 0)$, com valores de $\mathrm{Y}$ que ficaram em torno de 0,4 e 0,6. 


\subsection{Estudo das propriedades dos filmes de colágeno aditivados com extrato de boldo-do-Chile}

Os filmes de colágeno se apresentaram com um aspecto rugoso na face em contato com o ar de secagem, porém, a face em contato com a placa apresentou-se bastante lisa e brilhante (Figura 40). Os filmes foram preparados pela técnica "casting" que consiste em verter a solução sobre uma placa, à secagem foi realizada em estufa de circulação forçada à $30^{\circ} \mathrm{C}$.

Figura 40: Imagens dos filmes de colágeno produzidos na concentração de $6 \%$ (w/w).

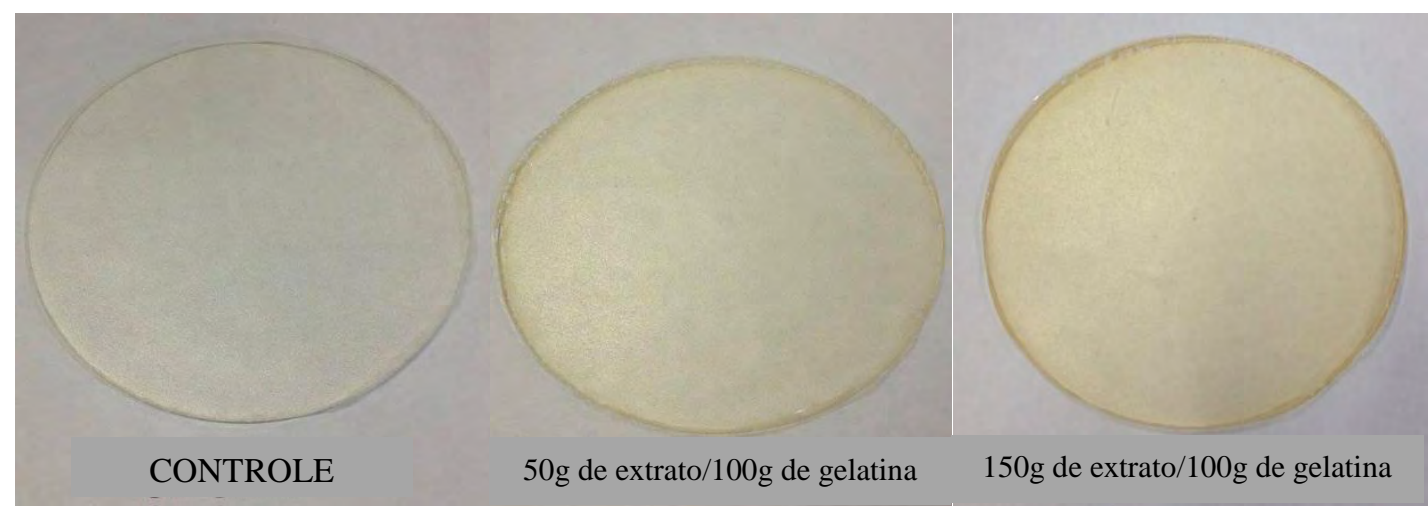

Fonte: Própria autoria

\subsubsection{Avaliação do efeito das concentrações do extrato de boldo-do-Chile e de colágeno nas propriedades mecânicas, solubilidade e propriedades óticas dos filmes}

Os filmes de colágeno também foram produzidos com quatro concentrações de diferentes $(2,4,6$ e $8 \mathrm{~g}$ de colágeno/100g de SF), e, com três concentrações do extrato aquoso de boldo-do-Chile (produzido à $45^{\circ} \mathrm{C}$, ver tópico 5.2.2): 0,50 e $150 \mathrm{~g}$ de extrato/ $100 \mathrm{~g}$ de colágeno. As propriedades estudadas nos filmes foram propriedades mecânicas (tração e perfuração), umidade, solubilidade e propriedades óticas (cor e opacidade). Ressaltando-se que todas as formulações foram produzidas em triplicata. 
5.6.1.1 Espessura dos filmes de colágeno

Com relação à espessura dos filmes de colágeno (Tabela 20) foi realizado o mesmo controle de massa de solução filmogênica/placa em função da concentração. Dessa forma foi possível manter a espessura dos filmes fixa, sem efeitos da concentração do colágeno (p>0,05). Percebeu-se que a adição do extrato de boldo-do-Chile também não afetou essa propriedade, de forma que a espessura média dos filmes ficou em torno $0,085 \mathrm{~mm}$.

Tabela 20: Espessura dos filmes de gelatina adicionados de extrato de boldo em diferentes concentrações de macromolécula e extrato de boldo-do-Chile

\begin{tabular}{cccc}
\hline C $\mathbf{C O L}$ & Controle & Espessura $(\mathbf{m m})$ & \\
& $0,087 \pm 0,006^{\mathrm{A}, \mathrm{a}}$ & $0,088 \pm 0,007^{\mathrm{A}, \mathrm{a}}$ & $\mathbf{1 5 0}$ \\
\hline $\mathbf{2}$ & $0,085 \pm 0,003^{\mathrm{A}, \mathrm{a}}$ & $0,084 \pm 0,006^{\mathrm{A}, \mathrm{a}}$ & $0,088 \pm 0,005^{\mathrm{A}, \mathrm{a}}$ \\
$\mathbf{4}$ & $0,086 \pm 0,006^{\mathrm{A}, \mathrm{a}}$ & $0,085 \pm 0,004^{\mathrm{A}, \mathrm{a}}$ & $0,083 \pm 0,006^{\mathrm{A}, \mathrm{a}}$ \\
$\mathbf{6}$ & $0,088 \pm 0,007^{\mathrm{A}, \mathrm{a}}$ & $0,087 \pm 0,002^{\mathrm{A}, \mathrm{a}}$ & $0,084 \pm 0,006^{\mathrm{A}, \mathrm{a}}$ \\
\hline
\end{tabular}

Fonte: Própria autoria.

$\mathrm{C}_{\mathrm{COL}}$ : Concentração de colágeno em g/100g de SF; Controle: formulação sem extrato de boldo; 50 : formulação com $50 \mathrm{~g}$ de extrato de boldo/100g de colágeno; 150 : formulação com $150 \mathrm{~g}$ de extrato de boldo/100g de colágeno.

A,B letras maiúsculas diferentes na mesma coluna indicam diferença significativa para o mesmo parâmetro.

a,b letras minúsculas diferentes na mesma linha indicam diferença significativa para o mesmo parâmetro.

\subsubsection{Umidade e solubilidade dos filmes de colágeno}

Não se observou efeito nem da concentração, nem da concentração do boldo-doChile sobre a umidades dos filmes ( $>00,05$ ), que permaneceu em torno de 15\% (Tabela 21). A umidade dos filmes de colágeno foi característica de filmes à base de proteínas plastificados com glicerol (SOBRAL; HABITANTE, 2001; VANIN et al., 2005).

A concentração de colágeno não apresentou efeito sobre a solubilidade dos filmes de colágeno $(\mathrm{p}>0,05)$, exceto para os filmes que continham de $150 \mathrm{~g}$ de extrato de boldo-doChile/100g de colágeno. Nessa condição, a concentração de $6 \%$ de colágeno apresentou o menor valor de solubilidade $63,4 \%$. 
Por outro lado, o efeito da concentração do extrato do boldo-do-Chile só pode ser percebido para a concentração de $8 \%$ de colágeno, de forma que a adição de $50 \mathrm{~g}$ de extrato/100g de colágeno apresentou o menor valor para a solubilidade $(63,9 \%)$, nessas condições.

Tabela 21: Valores para umidade e solubilidade para os filmes de colágeno adicionados de extrato de boldo em diferentes concentrações de macromolécula e extrato.

\begin{tabular}{ccccccc}
\hline \multirow{2}{*}{ C col } & \multicolumn{3}{c}{ Umidade (\%) } & \multicolumn{3}{c}{ Solubilidade (\%) } \\
& Controle & $\mathbf{5 0}$ & $\mathbf{1 5 0}$ & Controle & $\mathbf{5 0}$ & 150 \\
\hline $\mathbf{2}$ & $15,6 \pm 0,4^{\mathrm{A}, \mathrm{a}}$ & $15,3 \pm 0,1^{\mathrm{A}, \mathrm{a}}$ & $15,1 \pm 0,4^{\mathrm{A}, \mathrm{a}}$ & $66,3 \pm 2,0^{\mathrm{A}, \mathrm{a}}$ & $68,2 \pm 0,9^{\mathrm{A}, \mathrm{a}}$ & $68,1 \pm 1,4^{\mathrm{A}, \mathrm{a}}$ \\
$\mathbf{4}$ & $15,1 \pm 0,4^{\mathrm{A}, \mathrm{a}}$ & $14,8 \pm 0,4^{\mathrm{A}, \mathrm{a}}$ & $14,9 \pm 0,4^{\mathrm{A}, \mathrm{a}}$ & $65,5 \pm 2,6^{\mathrm{A}, \mathrm{a}}$ & $66,9 \pm 2,0^{\mathrm{A}, \mathrm{a}}$ & $67,4 \pm 1,2^{\mathrm{A}, \mathrm{a}}$ \\
$\mathbf{6}$ & $15,8 \pm 0,4^{\mathrm{A}, \mathrm{a}}$ & $15,2 \pm 0,4^{\mathrm{A}, \mathrm{a}}$ & $15,7 \pm 0,4^{\mathrm{A}, \mathrm{a}}$ & $65,4 \pm 0,6^{\mathrm{A}, \mathrm{a}}$ & $63,1 \pm 3,9^{\mathrm{A}, \mathrm{a}}$ & $63,4 \pm 1,1^{\mathrm{B}, \mathrm{a}}$ \\
$\mathbf{8}$ & $15,2 \pm 0,0^{\mathrm{A}, \mathrm{a}}$ & $15,1 \pm 0,2^{\mathrm{A}, \mathrm{a}}$ & $14,8 \pm 0,3^{\mathrm{A}, \mathrm{a}}$ & $66,1 \pm 0,3^{\mathrm{A}, \mathrm{a}}$ & $63,9 \pm 0,9^{\mathrm{A}, \mathrm{b}}$ & $65,5 \pm 1,1^{\mathrm{AB}, \mathrm{ab}}$ \\
\hline
\end{tabular}

Fonte: Própria autoria.

$\mathrm{C}_{\mathrm{COL}}$ : Concentração de colágeno em g/100g de SF; Controle: formulação sem extrato de boldo; 50 : formulação com $50 \mathrm{~g}$ de extrato de boldo/100g de colágeno; 150 : formulação com $150 \mathrm{~g}$ de extrato de boldo/100g de colágeno.

A,B letras maiúsculas diferentes na mesma coluna indicam diferença significativa para o mesmo parâmetro.

a,b letras minúsculas diferentes na mesma linha indicam diferença significativa para o mesmo parâmetro.

Wolf, Sobral e Telis (2009) observaram que a solubilidade de filmes de colágeno foi de $46 \%$ para uma concentração de $2 \%$ de macromoléculas, inferior ao obtido nesse estudo e pode estar correlacionado com a origem do colágeno empregado, ou sobre a presença das fibras colágeno usadas como reforço.

5.6.1.3 Propriedades mecânicas por testes de tração de filmes de colágeno

Os ensaios de tração para os filmes de colágeno (Tabela 22) mostraram que houve efeito significativo $(\mathrm{p}<0,05)$ da concentração da macromolécula na tensão na ruptura (TR, em MPa). A TR foi de 6,7 e 25,2MPa paras os filmes de 2 e $8 \mathrm{~g}$ de colágeno/100g de SF, respectivamente. Entretanto, não foi observado efeito sobre esta propriedade da concentração do extrato de boldo-do-Chile ( $p>0,05)$. 
Wolf, Sobral e Telis (2009) trabalharam com filmes de colágeno (2\%w/v) adicionados de fibras e obtiveram para a formulação controle (sem fibras) uma tensão na ruptura em torno de $6,8 \mathrm{MPa}$, sendo este valor bastante similar ao encontrado para a mesma concentração de colágeno deste estudo sem adição de extrato de boldo-do-Chile.

Angele et al. (2004) trabalharam com matrizes de colágeno (2,5w/v) reticuladas com EDC-NHS (EDC: 1-ethyl-3-(3-dimetil aminopropil) carbodiimida e NHS: Nhidroxisuccinimida) e para a formulação controle (sem reticulação) os valores de TR foram de 119kPa, ou seja inferiores ao valores de tensão deste estudo. Charulatha e Rajaram (2003) estudaram o comportamento mecânico de membranas de colágeno $(0,5 \%$ w/v) e obtiveram uma TR equivalente à 4,29MPa, valor este, que proporcionalmente a concentração de macromoléculas, é superior aos encontrados neste trabalho.

A elongação na ruptura (ER) dos filmes de colágeno também sofreu efeito da concentração da macromolécula $(\mathrm{p}<0,05)$. Quanto maior o teor de colágeno menor foi a elongação dos filmes (Tabela 22). Esse aumento pode ser explicado por uma maior resistência à tração dos filmes pela maior proximidade das macromoléculas o que facilita a formação da rede polimérica ao logo do processo de secagem. Porém, a adição do extrato de boldo-do-Chile não apresentou nenhum efeito sobre a ER dos filmes, mais uma vez reforçando a hipótese de que não houve interação dos polifenóis presentes no extrato de boldo-do-Chile e as cadeias polipeptídicas.

Wolf, Sobral e Telis (2009) obtiveram valores de ER equivalentes à 110\% para filmes de colágenos com $2 \%$ de macromoléculas, valores bastante semelhantes aos obtidos nesse estudo para a mesma concentração de colágeno.

Matrizes de colágeno reticuladas com EDC-NHS (EDC: 1-ethyl-3-(3-dimetil aminopropil) carbodiimida e NHS: N-hidroxisuccinimida) apresentaram valores de ER iguais à 9\%, para a formulação sem reticulação (ANGELE et al., 2004), já a ER para membranas de colágeno foi de 56\% (CHARULATHA; RAJARAM, 2003), as concentrações de macromoléculas nas SF que produziram as matrizes estudadas foram 2 e 2,5\%, respectivamente.

Em relação à rigidez dos filmes produzidos, propriedades esta que é representada pelo módulo de elasticidade (ME em MPa/\%), observou-se que nem a concentração, nem a concentração do extrato de boldo-do-Chile apresentou efeito significativo $(\mathrm{p}<0,05)$ sobre a mesma. Os valores obtidos foram, em média, iguais à 1,0MPa/\%. Wolf, Sobral e Telis (2009) obtiveram valores inferiores para o ME de filmes de colágeno com $2 \%$ de macromoléculas 
$(0,2 \mathrm{MPa} / \%)$, mesmo comportamento observado por Angele et al (2004), que detrminaram valores de $0,312 \mathrm{kPa} / \%$. 
Tabela 22: Valores da tensão na ruptura (TR), elongação na ruptura (ER) e módulo de elasticidade (ME) dos filmes de colágeno adicionados de extrato de boldo em diferentes concentrações de macromolécula e extrato.

\begin{tabular}{|c|c|c|c|c|c|c|c|c|c|}
\hline \multirow{2}{*}{ CCOL } & \multicolumn{3}{|c|}{ TR (MPa) } & \multicolumn{3}{|c|}{ ER (\%) } & \multicolumn{3}{|c|}{ ME (MPa/\%) } \\
\hline & Controle & 50 & 150 & Controle & 50 & 150 & Controle & 50 & 150 \\
\hline 2 & $6,7 \pm 0,4^{\mathrm{D}, \mathrm{a}}$ & $7,2 \pm 0,3^{\mathrm{D}, \mathrm{a}}$ & $7,0 \pm 0,5^{\mathrm{D}, \mathrm{a}}$ & $110,4 \pm 7,8^{\mathrm{A}, \mathrm{a}}$ & $108,4 \pm 4,5^{\mathrm{A}, \mathrm{a}}$ & $106,8 \pm 4,8^{\mathrm{A}, \mathrm{a}}$ & $1,1 \pm 0,1^{\mathrm{A}, \mathrm{a}}$ & $1,0 \pm 0,1^{\mathrm{A}, \mathrm{a}}$ & $1,1 \pm 0,1^{\mathrm{A}, \mathrm{a}}$ \\
\hline 4 & $13,8 \pm 0,6^{\mathrm{C}, \mathrm{a}}$ & $14,1 \pm 0,4^{\mathrm{C}, \mathrm{a}}$ & $14,4 \pm 0,5^{\mathrm{C}, \mathrm{a}}$ & $93,3 \pm 2,9^{\mathrm{B}, \mathrm{a}}$ & $93,6 \pm 3,1^{\mathrm{B}, \mathrm{a}}$ & $95,5 \pm 2,5^{\mathrm{B}, \mathrm{a}}$ & $1,1 \pm 0,2^{\mathrm{A}, \mathrm{a}}$ & $1,1 \pm 0,0^{\mathrm{A}, \mathrm{a}}$ & $1,1 \pm 0,1^{\mathrm{A}, \mathrm{c}}$ \\
\hline 6 & $19,5 \pm 0,8^{\mathrm{B}, \mathrm{a}}$ & $20,4 \pm 0,7^{\mathrm{B}, \mathrm{a}}$ & $21,1 \pm 1,4^{\mathrm{B}, \mathrm{a}}$ & $83,8 \pm 1,2^{\mathrm{BC}, \mathrm{a}}$ & $86,2 \pm 2,5^{\mathrm{B}, \mathrm{a}}$ & $88,0 \pm 1,1^{\mathrm{C}, \mathrm{a}}$ & $1,0 \pm 0,0^{\mathrm{A}, \mathrm{a}}$ & $1,0 \pm 0,0^{\mathrm{A}, \mathrm{a}}$ & $1,2 \pm 0,2^{\mathrm{A}, \mathrm{a}}$ \\
\hline 8 & $25,2 \pm 0,6^{\mathrm{A}, \mathrm{a}}$ & $24,9 \pm 0,5^{\mathrm{A}, \mathrm{a}}$ & $24,4 \pm 0,5^{\mathrm{A}, \mathrm{a}}$ & $73,1 \pm 2,1^{\mathrm{C}, \mathrm{a}}$ & $73,2 \pm 2,9^{\mathrm{C}, \mathrm{a}}$ & $76,3 \pm 1,2^{\mathrm{D}, \mathrm{a}}$ & $1,2 \pm 0,1^{\mathrm{A}, \mathrm{a}}$ & $1,2 \pm 0,0^{\mathrm{A}, \mathrm{a}}$ & $1,1 \pm 0,0^{\mathrm{A}, \mathrm{a}}$ \\
\hline
\end{tabular}

Fonte: Própria autoria.

$\mathrm{C}_{\mathrm{COL}}$ : Concentração de colágeno em g/100g de SF; Controle: formulação sem extrato de boldo; 50 : formulação com 50g de extrato de boldo/100g de colágeno; 150: formulação com $150 \mathrm{~g}$ de extrato de boldo/100g de colágeno.

A,B letras maiúsculas diferentes na mesma coluna indicam diferença significativa para o mesmo parâmetro.

a,b letras minúsculas diferentes na mesma linha indicam diferença significativa para o mesmo parâmetro. 
5.6.1.4 Propriedades mecânicas por testes de perfuração de filmes de colágeno

Os resultados obtidos para os testes de perfuração com os filmes de colágeno encontram-se na Tabela 23. Observou-se efeito significativo sobre a força na perfuração (FP, em $\mathrm{N}$ ) quando aumentou-se a concentração de colágeno $(\mathrm{p}<0,05)$, com exceção das concentrações de 6 e $8 \%$ que não apresentaram diferença estatística significativa entre si (p>0,05). Os valores para a FP variaram de 13,5 à 24,8N na formulação controle. Houve efeito sobre a FP devido à concentração do extrato de boldo-do-Chile nas concentrações extremas de colágeno ( 2 e $8 \%$ ), onde a concentração do extrato implicou em filmes menos resistentes a perfuração $(p<0,05)$. Para as concentrações de 4 e $6 \%$ não foi observado efeito significativo ( $p>0,05)$, embora, os valores para a FP das formulações que continham o extrato também foram discretamente inferiores à formulação controle, sugerindo que a concentração do extrato do boldo-do-Chile deixou os filmes menos resistentes à perfuração.

Para a deformação na perfuração (DP, em \%) observou-se o comportamento inverso, ou seja, quanto maior a concentração de colágeno, menos deformáveis foram os filmes $(\mathrm{p}<0,05)$, porém não havendo, de forma geral, efeito estatístico entre as concentrações de 6 e $8 \%$ de colágeno. A adição do extrato de boldo-do-Chile implicou em filmes mais deformáveis para todas as concentrações de colágeno estudadas.

Não existem relatos na literatura sobre ensaios de perfuração em filmes de colágeno, contudo, conforme já relatado, Gómez-Guillén et al. (2007), trabalhando com filmes de gelatina de atum adicionados de extrato de murta (Ugni molinae Turcz), observaram que a adição desse extrato implicou em filmes menos resistentes e mais deformáveis à perfuração. Esses autores ainda relataram que essa variação poderia ser atribuída à não formação de certas ligações, como as hidrogênio-hidrogênio. Vale ressaltar que a gelatina é produzida a partir do colágeno, dessa forma, sugere-se que provavelmente o extrato de boldo-do-Chile impediu a formação de algumas ligações durante a formação da matriz de colágeno. 
Tabela 23: Valores da força na perfuração (FP), deformação na perfuração (DP) dos filmes de colágeno adicionados de extrato de boldo em diferentes concentrações de macromolécula e extrato.

\begin{tabular}{ccccccc}
\hline \multirow{2}{*}{ CoL } & \multicolumn{3}{c}{ FP (N) } & & \multicolumn{3}{c}{ DP (\%) } \\
& Controle & $\mathbf{5 0}$ & $\mathbf{1 5 0}$ & Controle & $\mathbf{5 0}$ & $\mathbf{1 5 0}$ \\
\hline $\mathbf{2}$ & $13,5 \pm 0,3^{\mathrm{C}, \mathrm{a}}$ & $12,4 \pm 0,2^{\mathrm{C}, \mathrm{b}}$ & $12,1 \pm 0,5^{\mathrm{C}, \mathrm{b}}$ & $7,4 \pm 0,4^{\mathrm{A}, \mathrm{b}}$ & $8,7 \pm 0,1^{\mathrm{A}, \mathrm{a}}$ & $9,0 \pm 0,4^{\mathrm{A}, \mathrm{a}}$ \\
$\mathbf{4}$ & $18,5 \pm 1,2^{\mathrm{B}, \mathrm{a}}$ & $18,9 \pm 0,3^{\mathrm{B}, \mathrm{a}}$ & $18,0 \pm 0,3^{\mathrm{B}, \mathrm{a}}$ & $5,0 \pm 0,3^{\mathrm{B}, \mathrm{b}}$ & $5,4 \pm 0,1^{\mathrm{B}, \mathrm{b}}$ & $6,0 \pm 0,2^{\mathrm{B}, \mathrm{a}}$ \\
$\mathbf{6}$ & $23,4 \pm 0,2^{\mathrm{A}, \mathrm{a}}$ & $24,1 \pm 0,4^{\mathrm{A}, \mathrm{a}}$ & $23,5 \pm 0,6^{\mathrm{A}, \mathrm{a}}$ & $4,0 \pm 0,2^{\mathrm{C}, \mathrm{c}}$ & $4,7 \pm 0,2^{\mathrm{C}, \mathrm{b}}$ & $5,2 \pm 0,2^{\mathrm{C}, \mathrm{a}}$ \\
$\mathbf{8}$ & $24,8 \pm 0,7^{\mathrm{A}, \mathrm{a}}$ & $23,4 \pm 0,9^{\mathrm{A}, \mathrm{ab}}$ & $22,8 \pm 0,4^{\mathrm{A}, \mathrm{b}}$ & $3,5 \pm 0,4^{\mathrm{C}, \mathrm{b}}$ & $4,2 \pm 0,2^{\mathrm{C}, \mathrm{ab}}$ & $5,0 \pm 0,4^{\mathrm{C}, \mathrm{a}}$ \\
\hline
\end{tabular}

Fonte: Própria autoria.

$\mathrm{C}_{\mathrm{COL}}$ : Concentração de colágeno em g/100g de SF; Controle: formulação sem extrato de boldo; 50: formulação com $50 \mathrm{~g}$ de extrato de boldo/100g de colágeno; 150 : formulação com $150 \mathrm{~g}$ de extrato de boldo/100g de colágeno.

A,B letras maiúsculas diferentes na mesma coluna indicam diferença significativa para o mesmo parâmetro.

a,b letras minúsculas diferentes na mesma linha indicam diferença significativa para o mesmo parâmetro.

\subsubsection{Cor e opacidade}

Avaliando os parâmetros de cor obtidos para os filmes de colágeno percebeu-se que para a luminosidade ( $\left.L^{*}\right)$ não houve efeito da concentração de macromoléculas $(p>0,05)$. Entretanto, a adição do extrato de boldo-do-Chile implicou em filmes menos claros (Tabela 24). Para o parâmetro $a^{*}$, que mostra a variação do verde (-a*) ao vermelho ( $\left.a^{*}\right)$, observouse que a coloração dos filmes, de maneira geral, tende ao verde. Contudo, ainda que tenha havido efeito estatístico significativo $(\mathrm{p}<0,05)$, de maneira geral os valores foram muito próximos, sendo que o efeito da adição do extrato não foi tão expressivo (Tabela 24).

Já com relação ao parâmetro b*, que vai do azul (-b*) ao amarelo (b*), observou-se que a adição do extrato de boldo-do-Chile implicou em um aumento significativo $(\mathrm{p}<0,05)$ dos valores em direção ao amarelo. No entanto, a concentração de colágeno não influenciou expressivamente essa variável, embora tenha se observado efeito estatístico para algumas concentrações (Tabela 24). De forma geral, a cor dos filmes pode ser atribuída a adição do extrato de boldo-do-Chile, uma vez que, os parâmetros variam mediante o aumento na concentração de extrato adicionada. 
Tabela 24: Resultados obtidos dos parâmetros L*, a* e b* de filmes produzidos em diferentes concentrações de colágeno e extratos de boldo-doChile

\begin{tabular}{|c|c|c|c|c|c|c|c|c|c|}
\hline \multirow{2}{*}{ CCOL } & \multicolumn{3}{|c|}{$\mathbf{L}^{*}$} & \multicolumn{3}{|c|}{$\mathbf{a}^{*}$} & \multicolumn{3}{|c|}{$\mathbf{b}^{*}$} \\
\hline & Controle & 50 & 150 & Controle & 50 & 150 & Controle & 50 & 150 \\
\hline 2 & $91,2 \pm 0,4^{\mathrm{A}, \mathrm{a}}$ & $89,9 \pm 0,5^{\mathrm{A}, \mathrm{a}}$ & $88,0 \pm 0,6^{\mathrm{A}, \mathrm{b}}$ & $-0,8 \pm 0,1^{\mathrm{A}, \mathrm{a}}$ & $-0,8 \pm 0,0^{\mathrm{A}, \mathrm{a}}$ & $-0,9 \pm 1,0^{\mathrm{AB}, \mathrm{a}}$ & $5,1 \pm 0,2^{\mathrm{A}, \mathrm{c}}$ & $8,6 \pm 0,3^{\mathrm{A}, \mathrm{b}}$ & $14,8 \pm 1,0^{\mathrm{A}, \mathrm{a}}$ \\
\hline 4 & $90,9 \pm 0,4^{\mathrm{A}, \mathrm{a}}$ & $90,4 \pm 0,3^{\mathrm{A}, \mathrm{a}}$ & $88,5 \pm 0,4^{\mathrm{A}, \mathrm{b}}$ & $-0,8 \pm 0,1^{\mathrm{AB}, \mathrm{a}}$ & $-0,9 \pm 0,1^{\mathrm{A}, \mathrm{a}}$ & $-0,7 \pm 0,3^{\mathrm{A}, \mathrm{a}}$ & $4,9 \pm 0,5^{\mathrm{A}, \mathrm{c}}$ & $7,8 \pm 0,1^{\mathrm{B}, \mathrm{b}}$ & $12,4 \pm 1,1^{\mathrm{A}, \mathrm{a}}$ \\
\hline 6 & $91,7 \pm 0,3^{\mathrm{A}, \mathrm{a}}$ & $90,4 \pm 0,2^{\mathrm{A}, \mathrm{b}}$ & $89,1 \pm 0,1^{\mathrm{A}, \mathrm{c}}$ & $-1,0 \pm 0,0^{\mathrm{B}, \mathrm{a}}$ & $-1,0 \pm 0,0^{\mathrm{A}, \mathrm{a}}$ & $-1,2 \pm 0,1^{\mathrm{B}, \mathrm{b}}$ & $4,9 \pm 0,3^{\mathrm{A}, \mathrm{c}}$ & $7,7 \pm 0,2^{\mathrm{B}, \mathrm{b}}$ & $12,7 \pm 0,1^{\mathrm{A}, \mathrm{a}}$ \\
\hline 8 & $91,7 \pm 0,1^{\mathrm{A}, \mathrm{a}}$ & $90,6 \pm 0,2^{\mathrm{A}, \mathrm{a}}$ & $88,7 \pm 0,9^{\mathrm{A}, \mathrm{b}}$ & $-1,0 \pm 0,0^{\mathrm{B}, \mathrm{a}}$ & $-0,9 \pm 0,1^{\mathrm{A}, \mathrm{a}}$ & $-0,9 \pm 0,2^{\mathrm{AB}, \mathrm{a}}$ & $4,5 \pm 0,1^{\mathrm{A}, \mathrm{c}}$ & $7,7 \pm 0,3^{\mathrm{B}, \mathrm{b}}$ & $12,9 \pm 2,0^{\mathrm{A}, \mathrm{a}}$ \\
\hline
\end{tabular}

Fonte: Própria autoria.

$\mathrm{C}_{\mathrm{COL}}$ : Concentração de colágeno em g/100g de SF; Controle: formulação sem extrato de boldo; 50 : formulação com $50 \mathrm{~g}$ de extrato de boldo/100g de colágeno; 150: formulação com $150 \mathrm{~g}$ de extrato de boldo/100g de colágeno.

A,B letras maiúsculas diferentes na mesma coluna indicam diferença significativa para o mesmo parâmetro.

a,b letras minúsculas diferentes na mesma linha indicam diferença significativa para o mesmo parâmetro. 
A diferença total de cor $\left(\Delta \mathrm{E}^{*}\right)$ foi calculada considerando-se o padrão $\mathrm{L}^{*}=94,8$, a $\mathrm{a}^{*}=-$ $0,7, b^{*}=2,1$ (placa branca de referência) (Tabela 25). Observou-se que o $\Delta E^{*}$ foi influenciado pela adição do extrato, ou seja, os filmes tornaram-se mais coloridos quanto maior a quantidade de extrato adicionada (mais amarelados). Os filmes sem adição de extrato apresentaram valores de $\Delta \mathrm{E}^{*}$ médio em torno de 4,5 , enquanto que os filmes adicionados da maior concentração de extrato resultaram em um $\Delta \mathrm{E}^{*}$ médio equivalente à 13 . Essa variação na cor dos filmes pode ser atribuída aos pigmentos extraídos no processo de produção dos extratos (RATTAYA; BENJAKUL; PRODPRAN, 2009; BITENCOURT et al., 2014).

Tabela 25: Valores de diferença total de cor $\left(\Delta \mathrm{E}^{*}\right)$ e opacidade para os filmes produzidos em diferentes concentrações de colágeno e extrato de boldo-do-Chile.

\begin{tabular}{ccccccc}
\hline \multirow{2}{*}{ C $\mathbf{c o L}$} & \multicolumn{3}{c}{$\Delta \mathbf{E}^{*}$} & & \multicolumn{3}{c}{ Opacidade } \\
& Controle & $\mathbf{5 0}$ & $\mathbf{1 5 0}$ & Controle & $\mathbf{5 0}$ & $\mathbf{1 5 0}$ \\
\hline $\mathbf{2}$ & $4,7 \pm 0,4^{\mathrm{A}, \mathrm{c}}$ & $8,1 \pm 0,5^{\mathrm{A}, \mathrm{b}}$ & $14,4 \pm 1,2^{\mathrm{A}, \mathrm{a}}$ & $3,1 \pm 1,0^{\mathrm{A}, \mathrm{a}}$ & $2,4 \pm 0,7^{\mathrm{A}, \mathrm{a}}$ & $3,2 \pm 1,4^{\mathrm{AB}, \mathrm{a}}$ \\
$\mathbf{4}$ & $4,8 \pm 0,6^{\mathrm{A}, \mathrm{c}}$ & $7,2 \pm 0,3^{\mathrm{B}, \mathrm{b}}$ & $12,1 \pm 1,1^{\mathrm{A}, \mathrm{a}}$ & $3,1 \pm 1,0^{\mathrm{A}, \mathrm{b}}$ & $2,8 \pm 0,8^{\mathrm{A}, \mathrm{b}}$ & $5,6 \pm 0,8^{\mathrm{A}, \mathrm{a}}$ \\
$\mathbf{6}$ & $4,2 \pm 0,4^{\mathrm{A}, \mathrm{c}}$ & $7,1 \pm 0,3^{\mathrm{B}, \mathrm{b}}$ & $12,0 \pm 0,1^{\mathrm{A}, \mathrm{a}}$ & $5,3 \pm 1,7^{\mathrm{A}, \mathrm{a}}$ & $2,1 \pm 1,0^{\mathrm{A}, \mathrm{b}}$ & $2,8 \pm 0,8^{\mathrm{B}, \mathrm{ab}}$ \\
$\mathbf{8}$ & $3,9 \pm 0,0^{\mathrm{A}, \mathrm{b}}$ & $7,0 \pm 0,3^{\mathrm{B}, \mathrm{b}}$ & $12,4 \pm 2,2^{\mathrm{A}, \mathrm{a}}$ & $4,8 \pm 1,3^{\mathrm{A}, \mathrm{a}}$ & $3,8 \pm 0,7^{\mathrm{A}, \mathrm{a}}$ & $3,7 \pm 0,7^{\mathrm{AB}, \mathrm{a}}$ \\
\hline
\end{tabular}

Fonte: Própria autoria.

$\mathrm{C}_{\mathrm{COL}}$ : Concentração de colágeno em g/100g de SF; Controle: formulação sem extrato de boldo; 50 : formulação com $50 \mathrm{~g}$ de extrato de boldo/100g de colágeno; 150 : formulação com $150 \mathrm{~g}$ de extrato de boldo/100g de colágeno.

A,B letras maiúsculas diferentes na mesma coluna indicam diferença significativa para o mesmo parâmetro.

a,b letras minúsculas diferentes na mesma linha indicam diferença significativa para o mesmo parâmetro.

Não existem informações na literatura sobre cor e opacidade de filmes de colágeno adicionados de extratos de plantas. Contudo, Wolf (2009) estudou a adição de fibras em filmes de colágeno, produzindo uma formulação controle com $2 \%$ de colágeno. Os resultados obtidos para os parâmetros $L^{*}, a^{*}$ e b* mostraram-se levemente superiores aos encontrados nesse estudo $\left(\Delta \mathrm{E}^{*}=13,90\right)$, entretanto a opacidade dos filmes foi similiar $(\mathrm{Y}=3,5)$. 


\subsection{Propriedades de filmes de gelatina e colágeno produzidos com $6 \mathrm{~g}$ de macromoléculas/100g de SF aditivados com extrato de boldo-do-}

\section{Chile}

Escolheu-se a formulação com $6 \mathrm{~g}$ de macromoléculas/100g de SF para efetuar testes comparativos dos resultados obtidos nos tópicos 5.5 e 5.6, dos filmes produzidos com gelatina e colágeno. Observou-se que a espessura dos filmes não apresentou diferença estatística significativa entre as macromoléculas $(\mathrm{p}>0,05)$. Em relação às propriedades mecânicas, avaliando-se os resultados para o teste de tração, percebeu-se que os filmes de colágeno, de maneira geral, apresentaram valores de tensão na ruptura (TR) ligeiramente superiores aos valores dos filmes de gelatina $(\mathrm{p}<0,05)$, o mesmo comportamento foi observado para a elongação na ruptura (ER). Os filmes de gelatina mostraram-se mais resistentes à tração que os filmes de colágeno, uma vez que o módulo elástico (ME) dos filmes de gelatina foi 4 vezes maior que para os filmes de colágeno $(p<0,05)$. Para as propriedades mecânicas do teste de perfuração, não houve diferença $(p>0,05)$ em relação à força na perfuração (FP) dos filmes. Contudo, a deformação na perfuração (DP) dos filmes de gelatina mostrou-se superior aos filmes de colágeno.

Os filmes de gelatina e colágeno apresentaram valores semelhantes para a solubilidade em água, já a umidade foi ligeiramente maior nos filmes de colágeno. Com relação aos parâmetros de cor $\left(L^{*}, a^{*}\right.$ e $\left.b^{*}\right)$, embora tenha sido observada diferença estatística para o $\mathrm{L}^{*}$ e o a*, a diferença foi mais evidente para o $\mathrm{b}^{*}$, onde os filmes de colágeno apresentaram valores de $b^{*}$ maiores que para os filmes de gelatina, mostrando-se mais amarelados. A opacidade dos filmes de colágeno também foi estatisticamente maior $(\mathrm{p}<0,05)$ para os filmes de colágeno. 


\subsection{Caracterizações complementares dos filmes}

Além das caracterizações apresentadas em 5.5 e 5.6 para os filmes feitos com gelatina e colágeno aditivados com extrato de boldo-do-Chile, baseando-se nos critérios mencionados no tópico 4.9 foi escolhida uma concentração de macromoléculas $6 \mathrm{~g}$ de macromoléculas/100g de SF para a realização de outras análises, à título de complementação. As análises complementares realizadas foram: determinação das propriedades térmicas por calorimetria diferencial de varredura (DSC), análises de cristalinidade por difração de raio $\mathrm{X}$ (DRX), espectroscopia de infravermelho com transformada de Fourier (FTIR), permeabilidade ao vapor de água (PVA), microscopia eletrônica de varredura (MEV), brilho, determinação do ângulo de contato, propriedades de barreira UV/Visível e atividade antioxidante por ABTS. Foram produzidos filmes sem adição de extrato de boldo-do-Chile e com $50 \mathrm{~g}$ e $150 \mathrm{~g}$ de extrato de boldo-do-Chile/100g de macromoléculas. As análises foram realizadas em triplicata.

\subsubsection{Análises térmicas por calorimetria diferencial de varredura}

Os resultados obtidos nas análises térmicas mostram que tanto em filmes de gelatina, como em filmes de colágeno, na primeira varredura (linha contínua - Figura 41), houve uma transição vítrea $(\mathrm{Tg})$ que está relaciona às interações proteína-glicerol, seguida por um pico endotérmico, relacionado à fusão dos cristais das macromoléculas, indicando que os filmes produzidos são materiais semi-cristalinos. Na segunda varredura (linha tracejada - Figura 41), evidenciou-se somente a transição vítrea, deslocada para temperaturas menores, comportamento típico de materiais completamente amorfos.

Exemplos de termogramas obtidos para os filmes de gelatina e colágeno encontramse na Figura 41, as curvas obtidas para os filmes de gelatina foram bastante semelhantes às encontradas por Vanin et al. (2005), os termogramas dos filmes de colágeno apresentaram uma fusão mais complexa, provavelmente relacionada a heterogeneidade da macromolécula. 
Figura 41: Exemplos de termogramas para os filmes de gelatina e colágeno adicionados de diferentes concentrações de extrato de boldo Controle; $50 \mathrm{~g}$ de extrato de boldo/100g de macromoléculas; $150 \mathrm{~g}$ de extrato de boldo/100g de macromoléculas
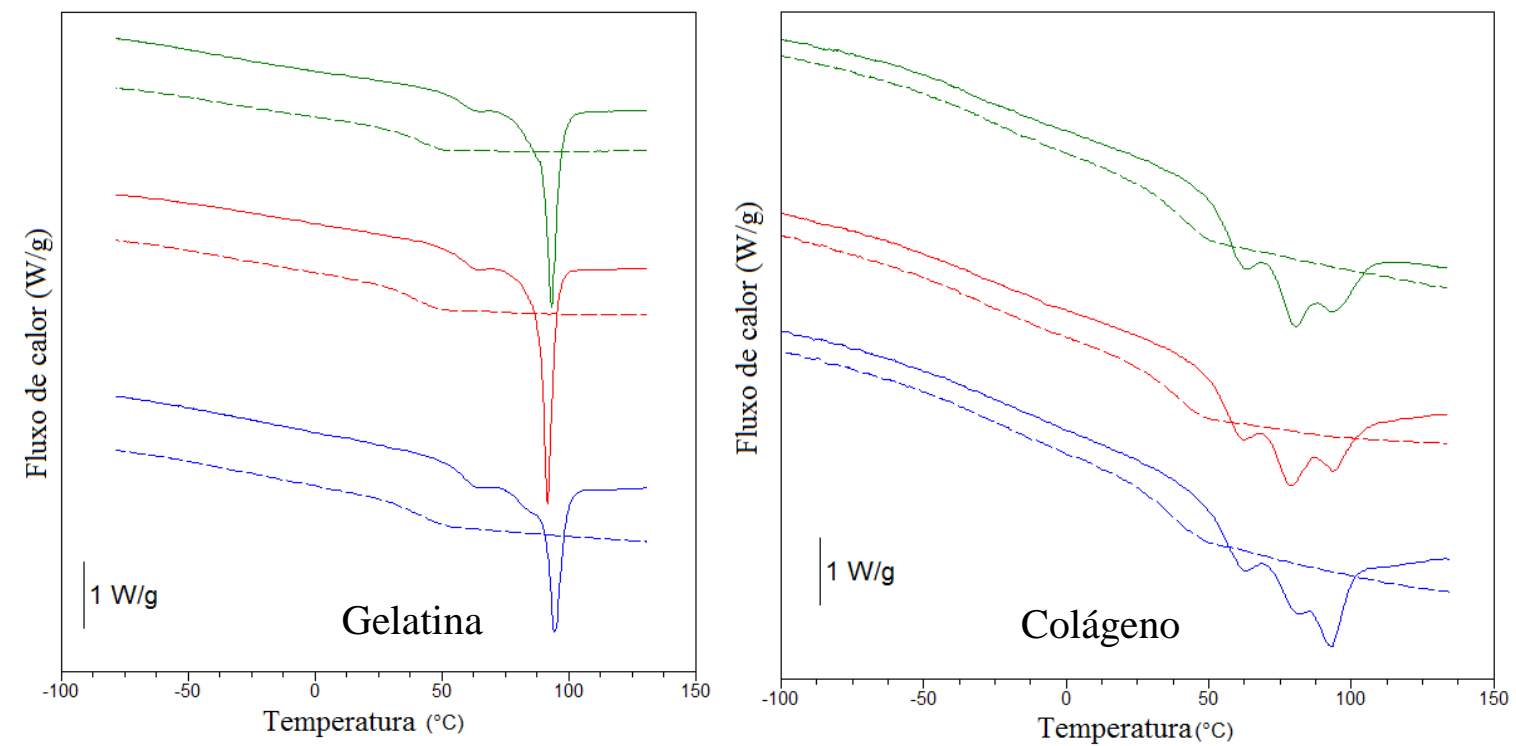

Fonte: Própria autoria

Os valores da transição vítrea (Tg), temperatura de fusão $(\mathrm{Tm})$ e entalpia de fusão $(\Delta \mathrm{H})$ determinados na primeira e segunda varredura encontram-se na Tabela 26. 
Tabela 26: Resultados dos parâmetros obtidos para as análises térmicas dos filmes de gelatina e colágeno adicionados de extrato de boldo-do-Chile em diferentes concentrações

\begin{tabular}{|c|c|c|c|}
\hline Parâmetros & CONTROLE & 50 & 150 \\
\hline \multicolumn{4}{|l|}{$\operatorname{Tg}\left({ }^{\circ} \mathrm{C}\right)$} \\
\hline Gelatina & $59,7 \pm 0,5^{\mathrm{A}, \mathrm{a}}$ & $58,3 \pm 1,4^{\mathrm{A}, \mathrm{a}}$ & $58,1 \pm 0,1^{\mathrm{A}, \mathrm{a}}$ \\
\hline Colágeno & $58,5 \pm 0,5^{\mathrm{A}, \mathrm{a}}$ & $56,8 \pm 0,5^{\mathrm{A}, \mathrm{ab}}$ & $56,4 \pm 1,0^{\mathrm{B}, \mathrm{b}}$ \\
\hline \multicolumn{4}{|l|}{$\operatorname{Tm}\left({ }^{\circ} \mathbf{C}\right)$} \\
\hline Gelatina & $93,4 \pm 0,3^{\mathrm{A}, \mathrm{a}}$ & $91,0 \pm 0,5^{\mathrm{A}, \mathrm{b}}$ & $93,3 \pm 1,2^{\mathrm{A}, \mathrm{a}}$ \\
\hline Colágeno & $81,1 \pm 0,6^{\mathrm{B}, \mathrm{b}}$ & $92,0 \pm 0,2^{\mathrm{A}, \mathrm{a}}$ & $92,5 \pm 1,0^{\mathrm{A}, \mathrm{a}}$ \\
\hline \multirow{2}{*}{\multicolumn{4}{|c|}{$\begin{array}{c}\Delta \mathrm{H}(\mathrm{J} / \mathrm{g} \text { de } \\
\text { macromoléculas })\end{array}$}} \\
\hline & & & \\
\hline Gelatina & $29,9 \pm 0,2^{\mathrm{A}, \mathrm{a}}$ & $29,0 \pm 0,9^{\mathrm{A}, \mathrm{a}}$ & $24,4 \pm 0,9^{\mathrm{A}, \mathrm{b}}$ \\
\hline Colágeno & $15,5 \pm 0,6^{\mathrm{B}, \mathrm{b}}$ & $17,4 \pm 0,6^{\mathrm{A}, \mathrm{a}}$ & $17,2 \pm 0,6^{\mathrm{A}, \mathrm{a}}$ \\
\hline $\operatorname{Tg}\left({ }^{\circ} \mathbf{C}\right)$ & CONTROLE & 50 & 150 \\
\hline Gelatina & $41,9 \pm 1,2^{\mathrm{A}, \mathrm{a}}$ & $38,9 \pm 1,1^{\mathrm{A}, \mathrm{a}}$ & $39,0 \pm 2,9^{\mathrm{A}, \mathrm{a}}$ \\
\hline Colágeno & $42,8 \pm 0,7^{\mathrm{A}, \mathrm{a}}$ & $40,6 \pm 0,6^{\mathrm{A}, \mathrm{ab}}$ & $39,4 \pm 1,8^{\mathrm{A}, \mathrm{b}}$ \\
\hline
\end{tabular}

Fonte: Própria autoria

Controle: formulação sem extrato de boldo-do-Chile; 50: formulação com 50g de extrato de boldodo-Chile/100g de macromoléculas; 150 : formulação com $150 \mathrm{~g}$ de extrato de boldo-do-Chile/100g de macromoléculas.

A,B letras maiúsculas diferentes na mesma coluna indicam diferença significativa para o mesmo parâmetro.

a,b letras minúsculas diferentes na mesma linha indicam diferença significativa para o mesmo parâmetro. 
Observou-se que a adição do extrato do boldo-do-Chile não provocou alteração na transição vítrea dos filmes de gelatina ( $p>0,05)$, sendo que a Tg média da primeira varredura para esses filmes foi de $58,7 \pm 0,8^{\circ} \mathrm{C}$ (Tabela 26). Entretanto, para os filmes de colágeno a adição do extrato diminuiu discretamente a $\mathrm{Tg}(\mathrm{p}<0,05)$, sendo que o filme controle (sem adição de extrato de boldo-do-Chile) apresentou uma $\mathrm{Tg}$ igual a $58,5 \pm 0,5^{\circ} \mathrm{C}$ e os filmes adicionados do extrato de boldo-do-Chile, apresentaram uma Tg média igual a $56,0 \pm 0,3^{\circ} \mathrm{C}$. Quando comparados os filmes de gelatina com os filmes de colágeno, foi possível observar que a $\mathrm{Tg}$ dos filmes de gelatina foi discretamente superior à dos filmes de colágeno $(\mathrm{p}>0,05)$, com efeito estatístico significativo somente para a formulação que continha $150 \mathrm{~g}$ de extrato de boldo-do-Chile/100g de macromoléculas $(\mathrm{p}<0,05)$.

Para os filmes de gelatina, a adição do extrato de boldo-do-Chile apresentou influência sobre a Tm $(\mathrm{p}<0,05)$, sendo que os filmes com $50 \%$ de extrato de boldo-do-Chile apresentaram o menor valor $\left(\mathrm{Tm}=91,0 \pm 0,5^{\circ} \mathrm{C}\right)$, as demais formulações apresentaram uma Tm média igual à $93,3 \pm 0,01^{\circ} \mathrm{C}$. Já para os filmes de colágeno a adição do extrato de boldo provocou um aumento significativo $(\mathrm{p}<0,05)$ na Tm dos filmes, sendo que para os filmes controle a Tm foi de $81,1^{\circ} \mathrm{C}$ e a Tm média dos filmes com extrato foi de $92,2^{\circ} \mathrm{C}$. Isso sugere que, a adição do extrato pode ter estabilizado a matriz polimérica dos filmes de colágeno (Tabela 26).

Comparando-se os filmes de gelatina e colágeno, em relação a Tm, observou-se que houve diferença significativa $(\mathrm{p}<0,05)$ entre os filmes sem adição de extrato de boldo-doChile. Essa diferença entre os valores de Tm pode ser atribuída a quebra de ligações provocada pelo abaixamento do $\mathrm{pH}$ na produção dos filmes de colágeno (Tabela 26).

O comportamento da entalpia de fusão $(\Delta \mathrm{H})$ dos filmes foi semelhante ao apresentado para Tm. A adição do extrato de boldo-do-Chile apresentou efeito sobre a energia necessária à fusão para os filmes de gelatina $(\mathrm{p}<0,05)$, sendo que esta foi menor para filmes produzidos com $150 \%$ de extrato de boldo $(\Delta \mathrm{H}=24,4 \mathrm{~J} / \mathrm{g}$ de macromoléculas). Entretanto, foi observado efeito sobre o valor de $\Delta H$ para os filmes de colágeno $(p<0,05)$, independentemente da concentração de extrato adicionada, o $\Delta \mathrm{H}$ foi maior que o apresentado para formulação controle. Esses resultados corroboram para a hipótese de que os compostos fenólicos presentes no extrato do boldo-do-Chile podem ter estabilizado as ligações na matriz polimérica dos filmes de colágeno.

A partir dos valores de Tg da segunda varredura (Tabela 26) observou-se que, mais uma vez, a adição do extrato não apresentou efeito sobre a transição vítrea (Tg) dos filmes 
de gelatina. Contudo, observou-se uma discreta diminuição no valor da Tg para os filmes de colágeno conforme aumentou-se a concentração do extrato adicionada. Hsu, Chai e Tsai (2004) relataram que polímeros contendo grupos hidroxi-fenólicos possuem menor temperatura de transição vítrea do que polímeros com ligações de hidrogênio.

Vanin et al. (2005), trabalhando com filmes de gelatina plastificados com diferentes plastificantes, obtiveram resultados bastante semelhantes para os parâmetros $\mathrm{Tg}$ (primeira e segunda varredura), Tm, e $\Delta \mathrm{H}$ dos filmes de gelatina. Akhtar et al. (2013) estudaram filmes de HPMC (hidroxipropilmetilcelulose) aditivados com um extrato comercial NRC (natural red color) extraído do suco de beterraba, rico em compostos fenólicos. Esses autores também tiveram uma diminuição no valor da transição vítreas dos filmes com extrato de NRC.

Figueiró et al. (2004) estudaram blendas de colágeno bovino com galactomanana, e a Tg determinada foi de $52,2^{\circ} \mathrm{C}$ na formulação contendo $100 \%$ colágeno, valor que foi semelhante ao obtido neste estudo. Resultados semelhantes também foram obtidos para a os filmes de colágeno por Ding, Zhang e Li (2015), que estudaram blendas de colágeno com $\operatorname{HPMC}\left(\mathrm{Tm}=56,2^{\circ} \mathrm{C}\right)$.

\subsubsection{Análises de cristalinidade por difratometria de raio $\mathrm{X}$}

Os difratogramas obtidos nas análises de cristalinidade dos filmes de gelatina e colágeno adicionados do extrato de boldo-do-Chile foram bastante semelhantes para ambas macromoléculas (Figura 42). Foi possível observar, em todos os casos, dois picos largos, o primeiro pico (Pico 1 - Figura 42) foi em torno de $2 \Theta=8^{\circ}$, que é relativo à estrutura de formação da tripla hélice do colágeno e da gelatina. O segundo pico (Pico 2 - Figura 42) foi aproximadamente igual a $2 \Theta=20^{\circ}$, este comportamento característico de materiais semicristalinos (BIGI; PANZAVOLTA; RUBINI; 2004; RIVERO; GARCIA; PINOTI, 2010; YAKIMETS et al., 2005; YAKIMETS et al., 2007).

A cristalinidade dos filmes não foi afetada pela adição do extrato de boldo-do-Chile, indicando que o extrato de boldo-do-Chile não influenciou na formação das redes cristalinas dos filmes. 
Figura 42: Exemplos de difratogramas para os filmes de gelatina e colágeno adicionados de $50 \mathrm{~g}$ de extrato de boldo-do-Chile/100g de macromoléculas
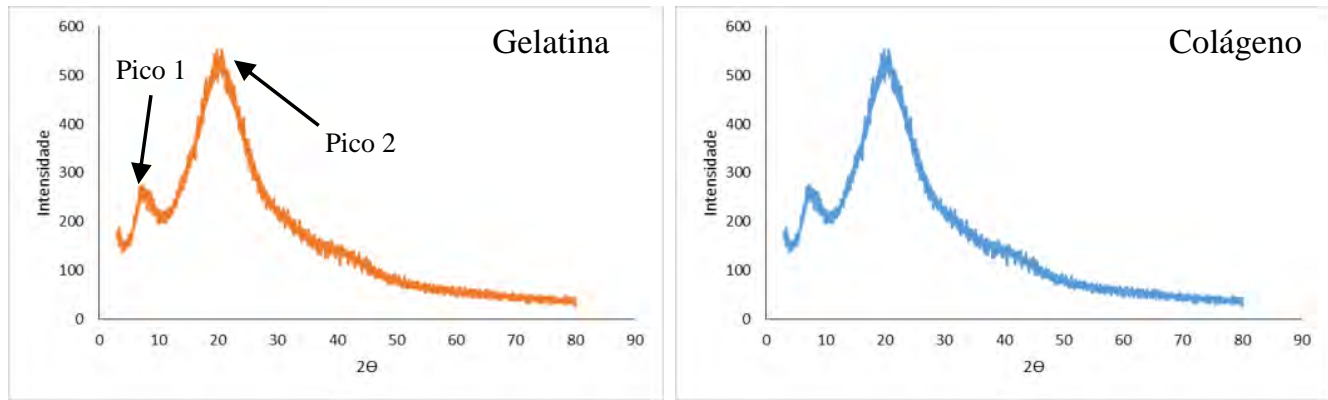

Fonte: Própria autoria.

Yakimets et al. (2005) estudaram filmes de gelatina e obtiveram espectros semelhantes aos obtidos nesta tese. Esses autores relataram que o processo de secagem influenciou na formação das triplas hélices dos filmes de gelatina, de forma que em filmes mais espessos (espessura $=100 \mu \mathrm{m})$, onde o tempo de secagem $(\sim 24 \mathrm{~h})$ foi maior que para os filmes finos (espessura $=10 \mu \mathrm{m}$ ), a formação de tripla hélice foi superior. Isso porque quando a secagem é mais lenta, as moléculas têm mais tempo para a formação das ligações. Os autores determinaram a porcentagem da fração cristalina relativa à tripla hélice diminui de 13 para $3 \%$. Outro fator que influencia na cristalinidade é a umidade final dos filmes, sendo que em unidades entre 13 e $15 \%$ estima-se que o maior valor de cristalinidade seja atingindo (YAKIMETS et al., 2007). Os filmes produzidos nesta tese podem ser considerados, segundo Yakimets et al. (2005), filmes espessos (espessura=85 $\mu \mathrm{m}$ ) cujo o tempo de secagem foi de aproximadamente $24 \mathrm{~h}$, além disso as umidades dos filmes de gelatina e colágeno foram em média 13 e 15\%, respectivamente, isso sugere que, de acordo com Yakimets et al., 2005 e Yakimets et al. (2007), que foi atingido o máximo de ligações tripla hélice formadas.

Rivero, Garcia e Pinoti (2010) trabalharam com filmes de gelatina plastificados com glicerol e também obtiveram difratogramas semelhantes aos obtidos nesta tese. Lima et al. (2006) estudaram blendas de colágeno e quitosana e também observaram nos filmes de colágeno, sem adição de quitosana, os mesmos tipos de difratogramas desta tese.

\subsubsection{Espectroscopia de infravermelho com transformada de Fourier (FTIR)}

De acordo com os espectros obtidos na a análise de espectroscopia de infravermelho com transformada de Fourier (FTIR) dos filmes de gelatina (Figura 43) e colágeno (Figura 
44), observou-se que os filmes das diferentes macromoléculas apresentaram espectros similares, isso pode ser justificado pela similaridade entre a gelatina e o colágeno. A gelatina é produzida a partir da hidrólise parcial do colágeno e a ambas apresentam em suas cadeias o triplete glucina-prolina-hidroxiprolina (GÓMEZ-GUILLÉN et al, 2011). Além disso, a adição do extrato de boldo-do-Chile não foi possível constatar mudanças no comportamento das interações químicas das substâncias envolvidas. Os espectros dos filmes foram bastante semelhantes, esses resultados indicam que que não houve interação entre os compostos fenólicos presentes nos extratos de boldo-do-Chile e as cadeias polipeptídicas de gelatina e colágeno, uma vez que não houve a formação de novas ligações.

Figura 43: Espectros obtidos para os filmes de gelatina produzidos com diferentes concentrações de extrato de boldo

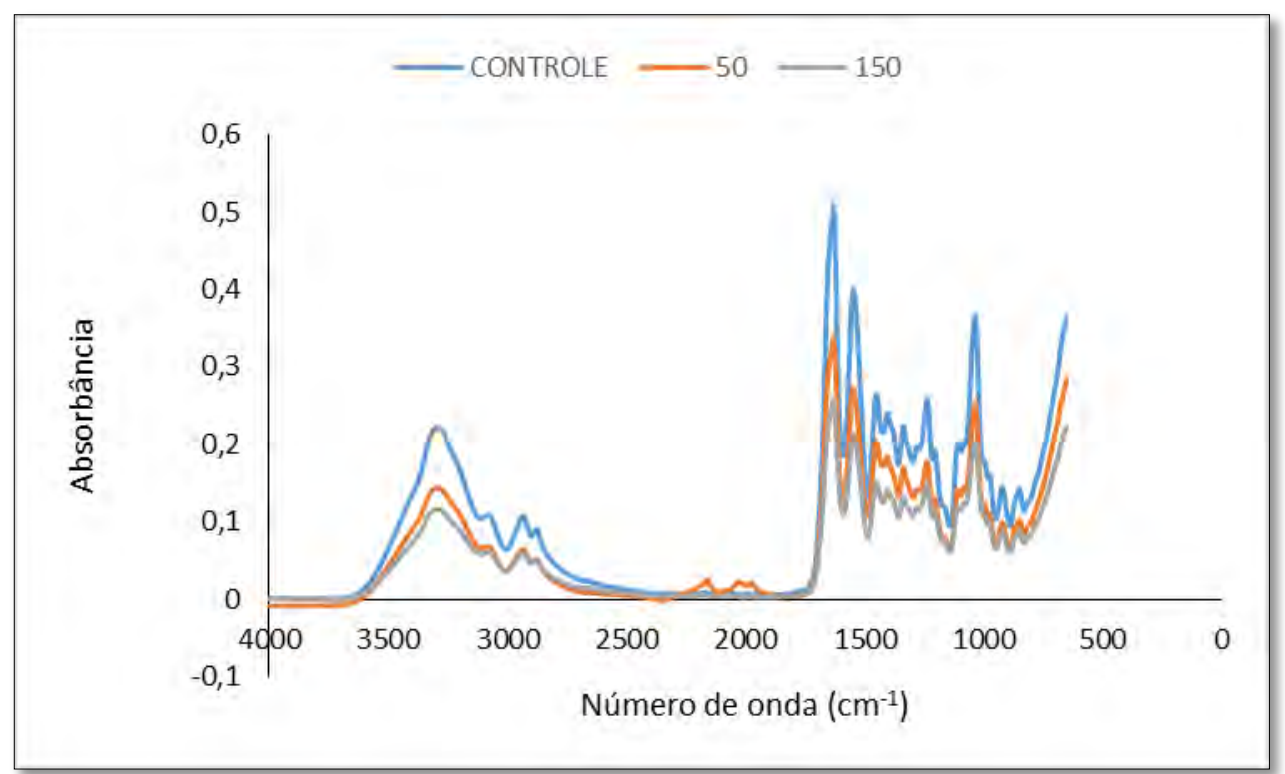

Fonte: Própria autoria

Controle: formulação sem extrato de boldo-do-Chile; 50: formulação com 50g de extrato de boldo-do-Chile/100g de gelatina; 150: formulação com 150g de extrato de boldo-doChile/100g de gelatina. 
Figura 44: Espectros obtidos para os filmes de colágeno produzidos com diferentes concentrações de extrato de boldo

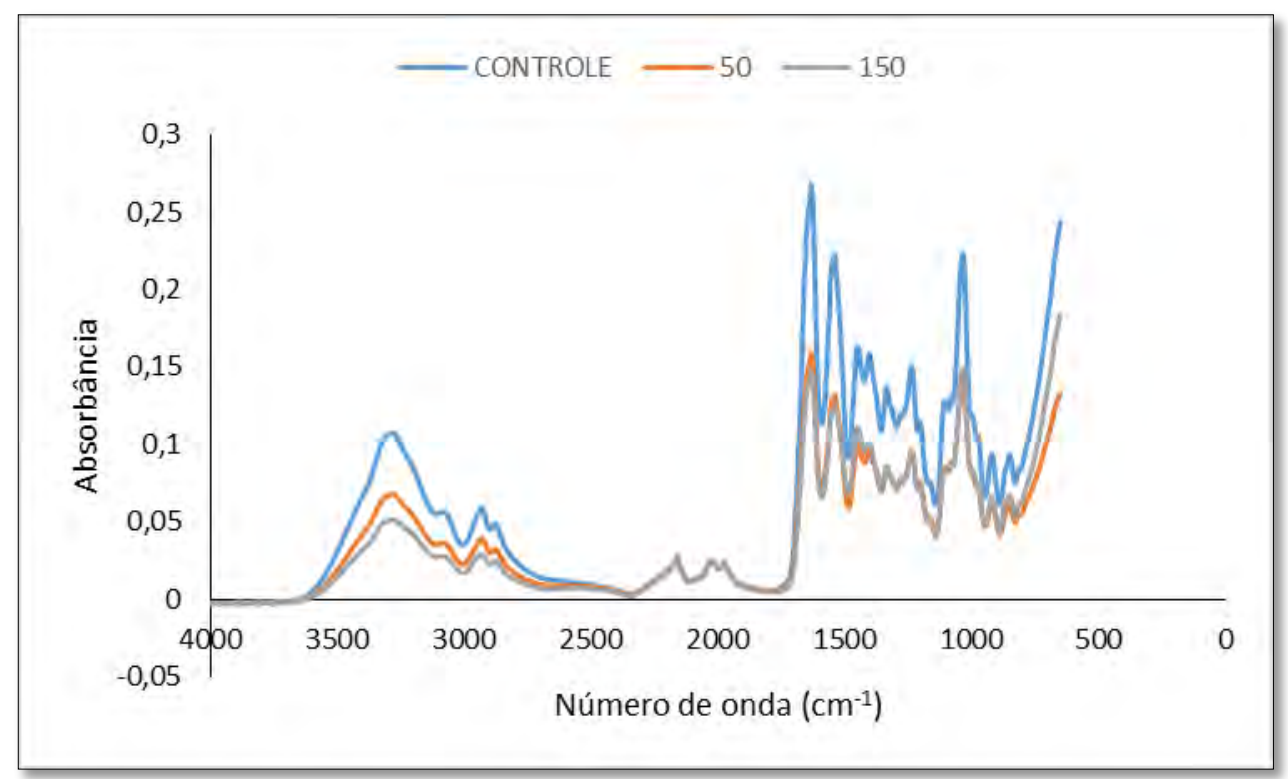

Fonte: Própria autoria

Controle: formulação sem extrato de boldo-do-Chile; 50: formulação com 50g de extrato de boldo-do-Chile/100g de gelatina; 150: formulação com $150 \mathrm{~g}$ de extrato de boldo-doChile/100g de gelatina.

A banda $3268 \mathrm{~cm}^{-1}$ representa o alongamento da ligação N-H. O alongamento da ligação C-H foi indicado em 2926 $\mathrm{cm}^{-1}$ (HOQUE; BENJAKUL; PRODPRAN, 2011). As bandas $1631,1537,1241 \mathrm{~cm}^{-1}$ representam respectivamente, amida primária (amida I), amida secundária (amida II) e amida terciária (amida III), sendo considerados picos característicos da gelatina e do colágeno (BERGO; SOBRAL, 2007; BITENCOURT et al., 2014; DING, ZHANG; LI, 2015; LI et al., 2014; LIMA et al., 2006). A amida primária representa a ligação $\mathrm{C}-\mathrm{O}$, e a amida secundária representa o alongamento vibracional da ligação $\mathrm{C}-\mathrm{N}$ e a deformação angular da ligação N-H (BITENCOURT et al., 2014). O pico em $1030 \mathrm{~cm}^{-1}$ está relacionado a presença de glicerol nos filmes (BERGO; SOBRAL, 2007; BITENCOURT et al., 2014).

Filmes de gelatina suína adicionados de extrato etánolico de cúrcuma também não apresentaram alterações nos espectros de infravermelho com transformada de Fourier (BITENCOURT et al., 2014). Hoque, Benjakul e Prodpran (2011) estudaram a adição de extratos de canela, cravo e anis em filmes de gelatina de peixe e tampouco observaram modificações nos espectros FTIR dos filmes. 


\subsubsection{Permeabilidade ao vapor de água}

De maneira geral, a adição do extrato de boldo não apresentou efeito sobre a permeabilidade ao vapor de água (PVA) tanto para os filmes de colágeno, como para os filmes de gelatina ( $>0,05)$ (Figura 45). Foi possível somente, observar que os filmes de gelatina foram menos permeáveis que os dos filmes de colágeno, sobretudo quando se adicionou $50 \%$ de extrato de boldo-do-Chile $(\mathrm{p}<0,05)$ (Figura 45). Os valores de PVA para os filmes de gelatina foram em média de $0,392 \pm 0,002 \mathrm{~g} \cdot \mathrm{mm} / \mathrm{m}^{2} . \mathrm{h} \cdot \mathrm{kPa}$ e para os filmes de colágeno $0,421 \pm 0,007 \mathrm{~g} \cdot \mathrm{mm} / \mathrm{m}^{2}$.h.kPa.

Wolf (2009) produziram filmes de colágeno $(2 \mathrm{~g}$ de colágeno/100mL de água) adicionados de fibras e para formulação controle (sem fibras) observaram uma PVA de $6,55 \times 10^{-5} \mathrm{~g} \cdot \mathrm{mm} / \mathrm{m}^{2} . \mathrm{h} . \mathrm{kPa}$, sendo este valor menor que o encontrado no presente trabalho, essa diferença pode ser explicada pela diferente origem do colágeno. Não foram encontradas informações na literatura para filmes de colágeno adicionados de extratos de plantas.

Figura 45: Permeabilidade ao vapor de água (PVA) para os filmes de gelatina e colágeno adicionados de extrato de boldo-do-Chile em diferentes concentrações

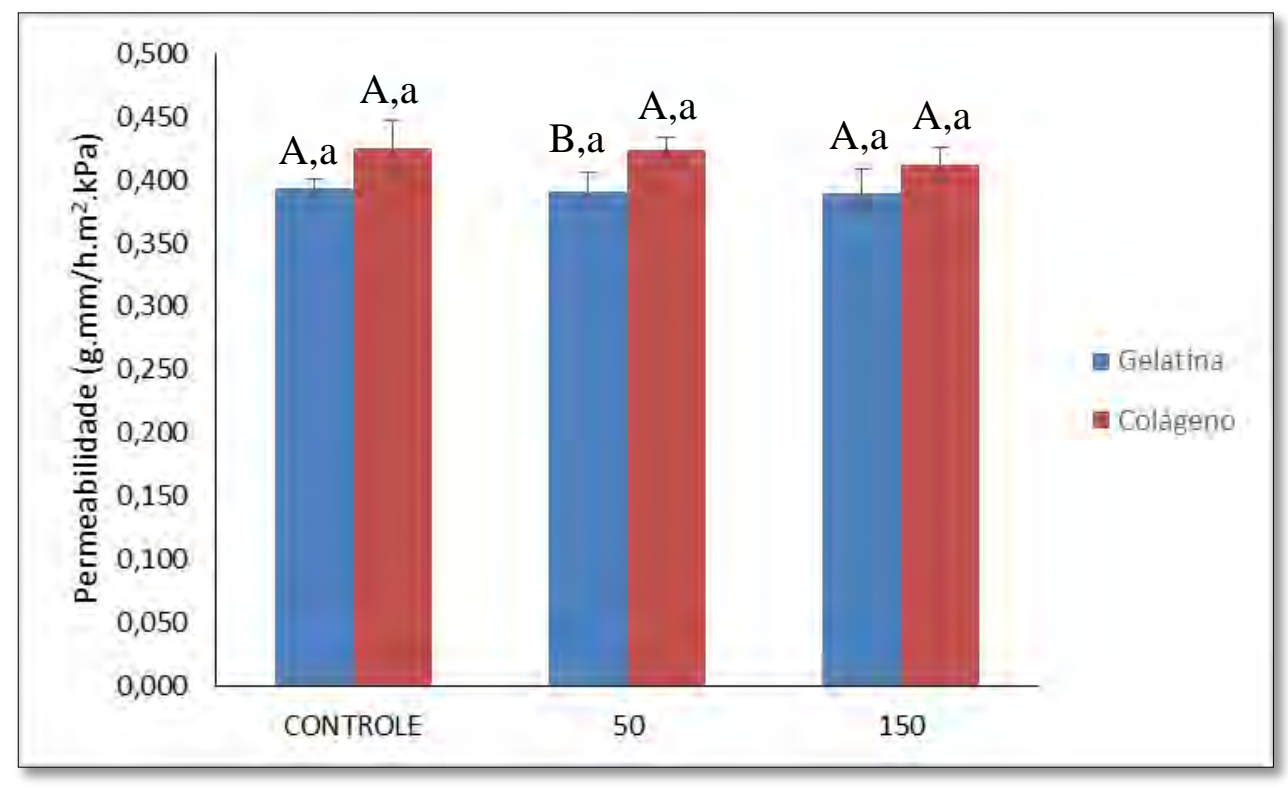

Fonte: Própria autoria

Controle: formulação sem extrato de boldo-do-Chile; 50: formulação com 50g de extrato de boldodo-Chile/100g de macromoléculas; 150: formulação com $150 \mathrm{~g}$ de extrato de boldo-do-Chile/100g de macromoléculas.

A,B letras maiúsculas diferentes entre macromoléculas diferentes indicam diferença significativa para a mesma concentração de extrato de boldo-do-Chile.

a,b letras minúsculas diferentes para a mesma macromolécula indicam diferença significativa para diferentes concentrações de extrato de boldo-do-Chile. 
Bitencourt et al. (2014) trabalharam com filmes de gelatina suína com extrato etanólico de cúrcuma plastificados com sorbitol, e encontraram valores para a PVA que variaram de $4,4 \times 10^{-7}$ a $3,6 \times 10^{-7} \mathrm{~g} \cdot \mathrm{mm} / \mathrm{cm}^{2} . \mathrm{h} . \mathrm{kPa}\left[0,0044\right.$ e $\left.0,0036 \mathrm{~g} \cdot \mathrm{mm} / \mathrm{m}^{2} . \mathrm{h} \cdot \mathrm{kPa}\right]$ para as formulações controle (sem adição de extrato) e a maior concentração de extrato $(200 \mathrm{~g}$ de extrato/100g de gelatina), respectivamente. Embora os valores tenham sido inferiores aos obtidos neste estudo, observou-se que houve efeito da adição do extrato sobre a PVA dos filmes. Li et al. (2014) estudaram filmes de gelatina de peixe ( $3 \mathrm{~g}$ de gelatina/100mL de água) adicionados de extratos comerciais (chá verde, semente de uva, gengibre e ginkgo) e obtiveram uma redução da PVA quando os filmes foram adicionados de extrato de chá verde (1,0mg de extrato/ml de SF), sendo que a PVA do filme controle foi $0,109 \mathrm{~g} . \mathrm{mm} / \mathrm{m}^{2} . \mathrm{h} . \mathrm{kPa}$ e com extrato de chá verde foi $0,075 \mathrm{~g} . \mathrm{mm} / \mathrm{m}^{2}$.h.kPa. Bitencourt et al. (2014) e Li et al. (2014) atribuíram a diminuição da permeabilidade ao vapor de água à interação dos polifenóis presentes nos extratos com as cadeias polipeptídicas da gelatina havendo a formação de ligações covalentes.

Por outro lado, Goméz-Guillen et al. (2007) estudaram a adição do extrato de murta em filmes de gelatina de peixe e observaram que a adição do extrato de murta não influenciou na permeabilidade de vapor de água dos filmes, sendo que esta ficou em torno de $0,216 \mathrm{~g} \cdot \mathrm{mm} / \mathrm{m}^{2}$.h.kPa para o filme controle e $0,287 \mathrm{~g} \cdot \mathrm{mm} / \mathrm{m}^{2} . \mathrm{h} . \mathrm{kPa}$ para o filme com extrato. Esses autores sugeriram que não houve interação entre os polifenóis do extrato de murta e as cadeias polipeptídicas da gelatina. Os resultados obtidos nesta tese corroboram com os resultados obtidos por Goméz-Guillen et al. (2007), uma vez que não houve diferença na permeabilidade ao vapor de água.

\subsubsection{Microscopia eletrônica de varredura (MEV)}

Observando-se as micrografias dos filmes de gelatina (Figura 46), percebeu-se que as superfícies dos filmes, tanto lado em contato com ar (Figura 46 a, b, c) como do lado em contato com a placa (Figura 46 c, d, e), se apresentaram bastante homogêneas, com ausência de rugosidade ou falhas. E ainda, a adição do extrato de boldo-do-Chile não provocou alteração nas mesmas. A seção transversal dos filmes (Figura 46 g, h, i) também se mostrou com a superfície bastante lisa e compactada típica de filmes de hidrocolóides. 
Figura 46: Micrografias de filmes de gelatina da superfície de secagem (a), (b), (c), em contato com a placa (d), (e), (f) e criofraturada (g), (h), (i) (aumento de 1,0k)
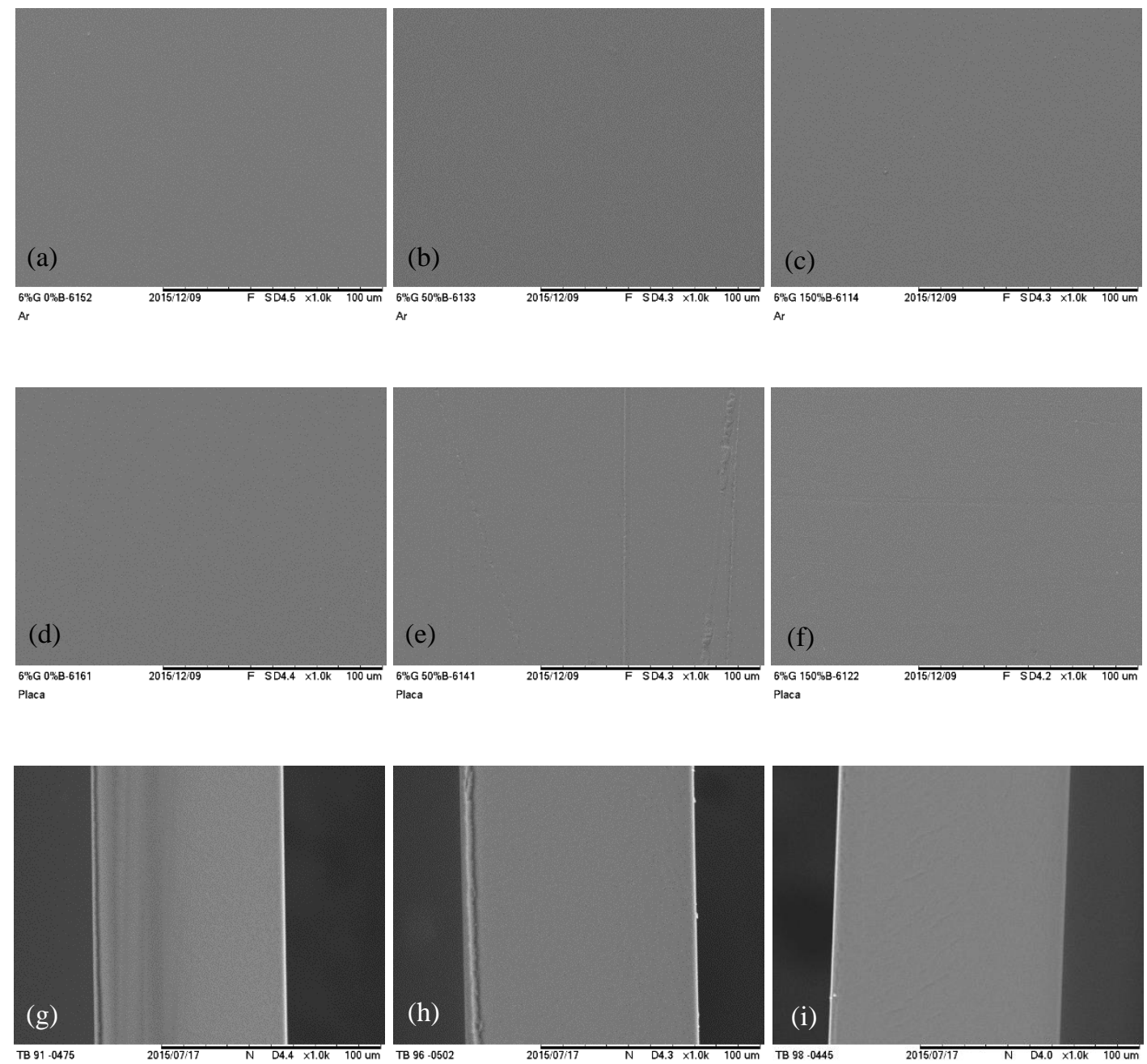

Fonte: Própria Autoria

Controle: (a); (d); (g)

$50 \mathrm{~g}$ de extrato de boldo $/ 100 \mathrm{~g}$ de gelatina: (b), (e), (h) $150 \mathrm{~g}$ de extrato de boldo/100g de gelatina (c), (f), (i)

Já as micrografias dos filmes de colágeno, mostraram superfícies de secagem (Figura $47 \mathrm{a}, \mathrm{b}, \mathrm{c})$ heterogêneas, com aspecto rugoso. Entretanto, a superfície que ficou em contato com a placa (Figura 47 d, e, f) mostrou-se lisa e homogênea. A solução filmogênica de colágeno é uma dispersão, onde é possível observar a presença de pequenas partículas insolubilizadas. O processo de secagem provavelmente provocou o arraste dessas partículas para a superfície fazendo com que esta tivesse um aspecto rugoso, diferente da superfície em contato com a placa. Com relação à seção transversal dos filmes de colágeno (Figura 47 g, h, i), foi possível observar uma estrutura levemente heterogênea, com presença de algumas 
estrias. Além disso, foi possível observar a ondulação no lado direito das imagens (superfície de secagem), o que ressaltou a já mencionada rugosidade desta superfície. Em nenhum dos casos, observou-se que a adição do extrato de boldo-do-Chile alterou as imagens obtidas.

Figura 47: Micrografias dos filmes de colágeno da superfície de secagem (a), (b), (c), em contato com a placa (d), (e), (f) e criofraturada (g), (h), (i) (aumento de 1,0k)
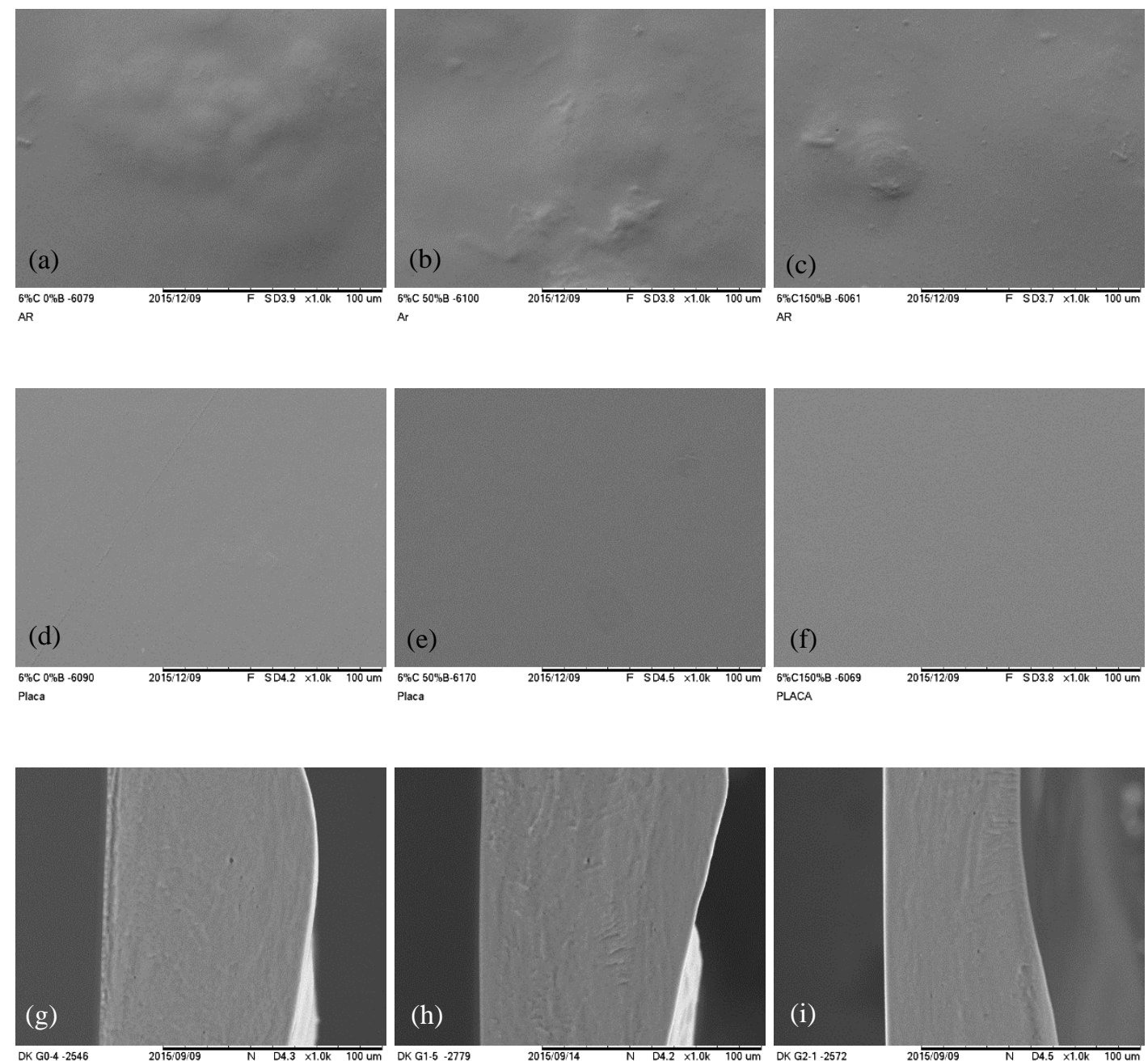

Fonte: Própria Autoria

Controle: (a); (d); (g)

$50 \mathrm{~g}$ de extrato de boldo/100g de colágeno: (b), (e), (h)

$150 \mathrm{~g}$ de extrato de boldo/100g de colágeno (c), (f), (i)

Gómez-Guillén et al. (2007) estudaram a adição de extrato aquoso de murta em filmes de gelatina de peixe, e constataram que a adição deste extrato deixou a superfície dos filmes mais homogênea e coesa. Já para filmes de gelatina de peixe adicionada de extratos comerciais de chá verde, gengibre, semente de uva e ginkgo não foi observada diferença nas superfícies dos filmes adicionados dos extratos (LI et al., 2014). 
Para filmes de colágeno, Sionkowska (2000) e Tang et al. (2015) observaram a presença de rugosidades nas superfícies dos filmes, sendo estas atribuídas a diferenças na conformação primária da estrutura da molécula de colágeno. Segundo, Persikov et al. (2000) existem alguns aminoácidos que possuem cadeias laterais volumosas que quando entram na posição X ou Y da sequência glicina-X-Y resultam na formação de fibras.

\subsubsection{Brilho}

O brilho dos filmes de gelatina e colágeno não foi influenciado pela adição do extrato de boldo-do-Chile ( $>>0,05)$ independente da superfície avaliada (Tabela 27). Entretanto, quando se comparou os filmes de gelatina com os filmes de colágeno foi possível observar que os filmes de gelatina foram mais brilhantes que os de colágeno $(\mathrm{p}<0,05)$ para todas as concentrações de extrato de boldo-do-Chile, independente da superfície analisada.

Tabela 27: Brilho dos filmes de gelatina e colágeno da superfície em contato com o ar de secagem

\begin{tabular}{cccc}
\hline Macromoléculas & \multicolumn{3}{c}{${\text { Brilho }(\mathbf{G U})-\mathbf{6 0}^{\circ}}$} \\
$(\mathbf{6 g} / \mathbf{1 0 0 g}$ de SF) & CONTROLE & $\mathbf{5 0}$ & $\mathbf{1 5 0}$ \\
\hline Gelatina (AR) & $157,4 \pm 1,2^{\mathrm{A}, \mathrm{a}}$ & $144,8 \pm 7,1^{\mathrm{A}, \mathrm{a}}$ & $147,3 \pm 7,2^{\mathrm{A}, \mathrm{a}}$ \\
Gelatina (PLACA) & $153,9 \pm 4,3^{\mathrm{A}, \mathrm{a}}$ & $138,1 \pm 12,4^{\mathrm{A}, \mathrm{a}}$ & $141,1 \pm 11,7^{\mathrm{A}, \mathrm{a}}$ \\
Colágeno (AR) & $21,2 \pm 0,7^{\mathrm{C}, \mathrm{a}}$ & $19,6 \pm 1,0^{\mathrm{C}, \mathrm{a}}$ & $20,4 \pm 0,1^{\mathrm{C}, \mathrm{a}}$ \\
Colágeno (PLACA) & $95,2 \pm 0,3^{\mathrm{B}, \mathrm{a}}$ & $94,8 \pm 1,3^{\mathrm{B}, \mathrm{a}}$ & $95,0 \pm 0,7^{\mathrm{B}, \mathrm{a}}$ \\
\hline
\end{tabular}

Fonte: Própria autoria

Controle: formulação sem extrato de boldo-do-Chile; 50: formulação com 50g de extrato de boldodo-Chile/100g de macromoléculas; 150 : formulação com $150 \mathrm{~g}$ de extrato de boldo-do-Chile/100g de macromoléculas.

A,B letras maiúsculas diferentes na mesma coluna indicam diferença significativa para a mesma concentração de extrato de boldo-do-Chile.

a,b letras minúsculas diferentes na mesma linha indicam diferença significativa para as diferentes concentrações de extrato de boldo-do-Chile.

Foi possível observar que, para os filmes de colágeno (Tabela 27), as respostas para a superfície em contato com o ar de secagem foram menos brilhantes que as superfícies em contato com a placa $(\mathrm{p}<0,05)$. Contudo, esse comportamento não foi observado para os filmes de gelatina. Esses resultados corroboram com as informações obtidas nas 
micrografias já apresentadas (ver tópico 5.8.5), onde a superfície dos filmes de colágeno em contato com o ar mostrou-se rugosa. Villalobos et al. (2005) relataram que o brilho dos filmes está correlacionado com a morfologia da superfície, sendo que quanto maior a rugosidade, menor será o valor de seu brilho.

Os resultados obtidos nesta tese, para os filmes de gelatina sem extrato de boldo-doChile, foram semelhantes aos encontrados por Bitencourt et al. (2014) para os filmes de gelatina suína, também sem extrato. Entretanto, esses autores observaram que o aumento da concentração do extrato etanólico de cúrcuma implicou em uma diminuição do brilho dos filmes de gelatina.

\subsubsection{Determinação do ângulo de contato}

Os ângulos de contato determinados $\left(\Theta, \mathrm{em}^{\circ}\right)$ apresentaram valores maiores para dos filmes de gelatina que para os filmes de colágeno (Tabela 28). Além disso, a adição do extrato de boldo-do-Chile diminuiu o ângulo de contato para o lado placa dos filmes de gelatina (Tabela 28) $(\mathrm{p}<0,05)$, essa tendência permaneceu na superfície em contato com o ar para estes filmes, embora sem efeito estatístico ( $p>0,05)$.

Também para os filmes de colágeno, a adição do extrato de boldo-do-Chile, implicou em valores de $\Theta$ menores tanto para o lado em contato com o ar, como para do lado em contato com a placa (Tabela 28), esses resultados sugerem que o aumento da concentração do extrato aumentou a hidrofilicidade das superfícies.

De maneira geral, os resultados para a determinação do ângulo de contato dos filmes adicionados de extrato de boldo-do-Chile mostraram que os filmes de gelatina possuem uma superfície mais hidrofóbica que os filmes de colágeno (Tabela 28) para ambos os lados do filme ( $\mathrm{p}<0,05)$, considerando-se que os ângulos determinados apresentaram valores maiores para dos filmes de gelatina que para os filmes de colágeno. 
Tabela 28: Resultados do ângulo de contato dos filmes de gelatina e colágeno da superfície em contato com o ar de secagem

\begin{tabular}{cccc}
\hline Macromoléculas & \multicolumn{3}{c}{ Ângulo de contato $\left({ }^{\circ}\right)-\mathbf{3 0 s}$} \\
$(\mathbf{6 g} / \mathbf{1 0 0 g}$ de SF) & CONTROLE & $\mathbf{5 0}$ & $\mathbf{1 5 0}$ \\
\hline Gelatina (AR) & $87,5 \pm 0,5^{\mathrm{B}, \mathrm{a}}$ & $85,9 \pm 2,2^{\mathrm{B}, \mathrm{a}}$ & $84,5 \pm 0,9^{\mathrm{B}, \mathrm{a}}$ \\
Gelatina (PLACA) & $95,1 \pm 1,6^{\mathrm{A}, \mathrm{a}}$ & $90,6 \pm 2,4^{\mathrm{A}, \mathrm{b}}$ & $90,6 \pm 1,9^{\mathrm{A}, \mathrm{a}}$ \\
Colágeno (AR) & $77,5 \pm 1,1^{\mathrm{C}, \mathrm{a}}$ & $75,5 \pm 0,5^{\mathrm{C}, \mathrm{a}}$ & $72,2 \pm 1,3^{\mathrm{C}, \mathrm{b}}$ \\
Colágeno (PLACA) & $87,4 \pm 0,8^{\mathrm{B}, \mathrm{a}}$ & $83,6 \pm 1,6^{\mathrm{B}, \mathrm{b}}$ & $83,5 \pm 1,7^{\mathrm{B}, \mathrm{b}}$ \\
\hline
\end{tabular}

Fonte: Própria autoria

Controle: formulação sem extrato de boldo-do-Chile; 50: formulação com 50g de extrato de boldodo-Chile/100g de macromoléculas; 150: formulação com $150 \mathrm{~g}$ de extrato de boldo-do-Chile/100g de macromoléculas.

A,B letras maiúsculas diferentes na mesma coluna indicam diferença significativa para a mesma concentração de extrato de boldo-do-Chile.

a,b letras minúsculas diferentes na mesma linha indicam diferença significativa para as diferentes concentrações de extrato de boldo-do-Chile.

Comparando-se os resultados da superfície de secagem e a superfície em contato com a placa (Tabela 28), percebeu-se que os valores de $\Theta$ para a superfície de secagem foi inferior aos obtidos para a superfície em contato com a placa para todos os tratamentos. Para os filmes de colágeno, esse resultado pode ser facilmente justificado pela rugosidade do lado ar, que foi apontada nas micrografias e confirmada nas análises de brilho (ver tópicos 5.8.5 e 5.8.6). Exemplos das imagens capturadas pelo durante as análises estão apresentadas Figura 48 e 49. 
Figura 48: Exemplos de imagens capturadas na determinação do ângulo de contato para filmes de colágeno das superfícies em contato com ar (a, b, c) e em contato com a placa (d, e, f)

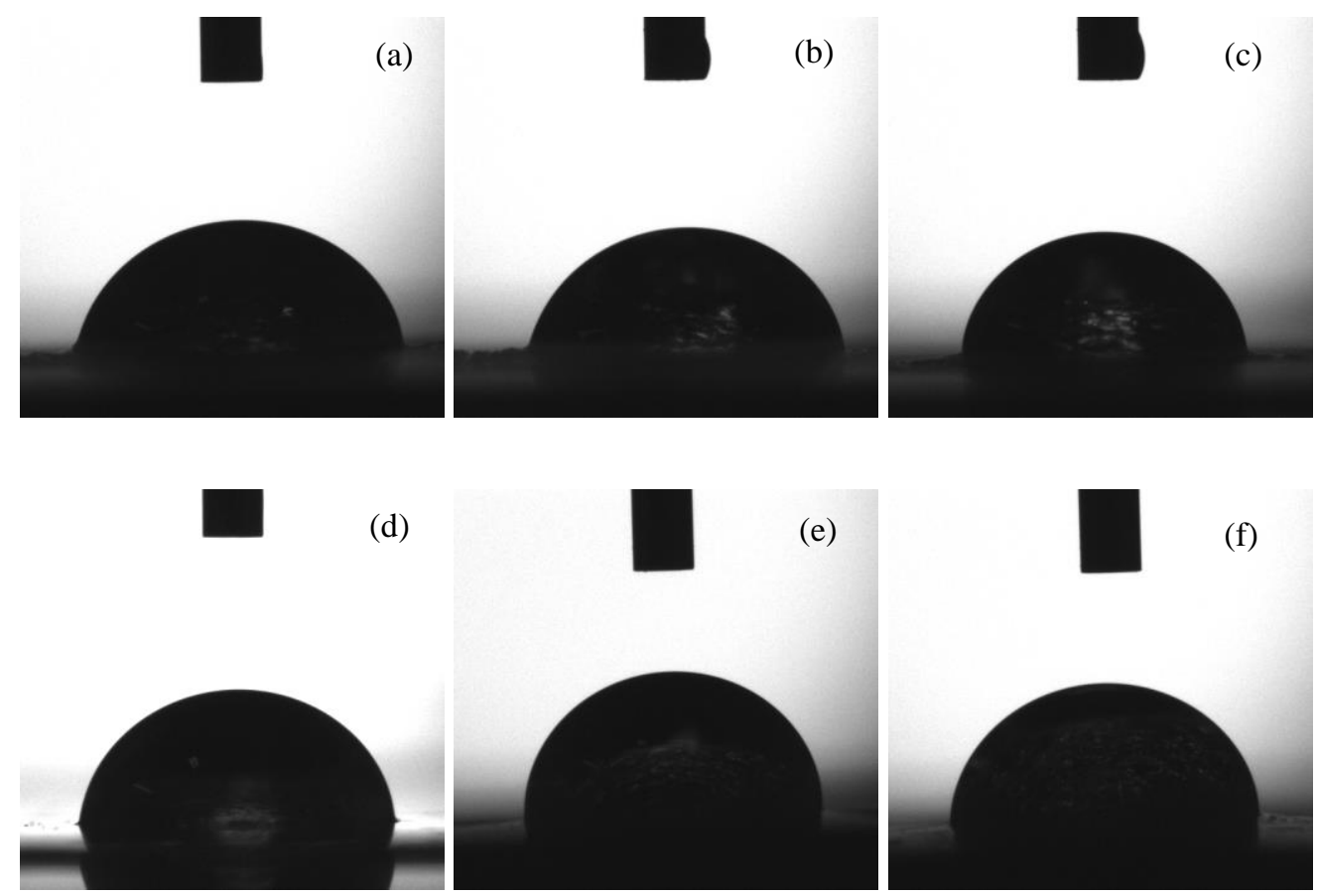

Fonte: Própria autoria 
Figura 49: Exemplos de imagens capturadas na determinação do ângulo de contato para filmes de gelatina das superfícies em contato com ar (a, b, c) e em contato com a placa (d, e, f)

(a)

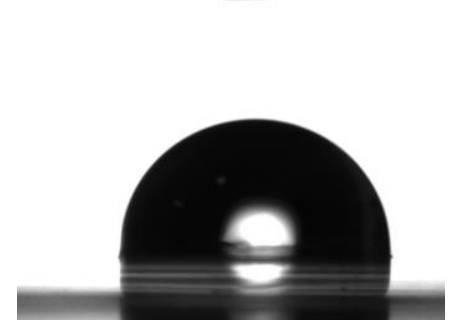

(d)

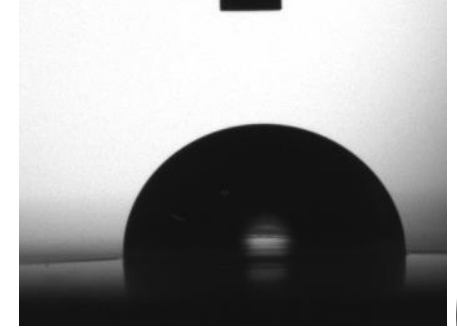

(b)

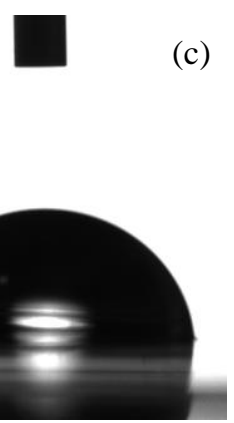

(e)
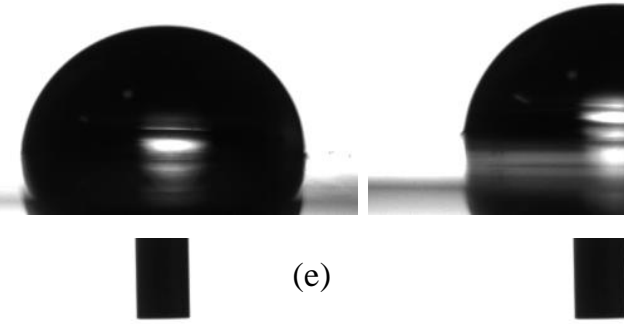

(f)

(c)

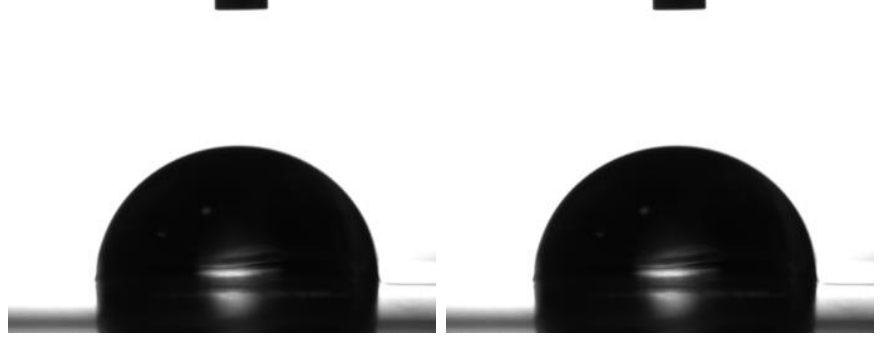

Filmes de gelatina adicionados de extrato aquoso de alga marinha (Ascophyllum nodosum), rico em compostos fenólicos, também apresentaram decréscimo nos valores para o ângulo de contato a medida em que foi aumentada a concentração do extrato (KADAM et al., 2015). Esses autores relataram que a presença de vários grupos hidroxila, nos compostos fenólicos do extrato, aumentou a polaridade da superfície diminuindo, por consequência, o ângulo de contato. $\mathrm{O}$ extrato de boldo-do-Chile incorporado nos filmes de gelatina e colágeno deste estudo, também possui substâncias com alta polaridade, então, pode-se sugerir que houve aumento da polaridade da superfície pela presença de tais compostos.

Contudo, os filmes produzidos no presente trabalho podem ser considerados hidrofóbicos, isso, segundo a definição de Vogler (1998) onde superfícies com $\Theta>65^{\circ}$ podem ser consideradas hidrofóbicas. 


\subsubsection{Propriedades de barreira à luz (UV/Visível)}

De maneira geral, todos os compostos orgânicos podem absorver a radiação eletromagnética, porque possuem elétrons na camada de valência que podem ser excitados para níveis superiores em energia. Entretanto, para o caso da radiação no comprimento de onda do UV/Visível (200 a 700nm) só é possível a absorção de radiação, caso as moléculas sejam cromóforas. Ou seja, estas moléculas devem apresentar grupamentos insaturados intercalados que possibilitem a transição de elétrons de orbitais não ligantes (n) ou ligantes $\pi$ para orbitais antiligantes $\pi^{*}$ (SKOOG; HOLLER; CROUCH, 2007).

Observou-se que, de maneira geral, tanto os filmes de gelatina, como os filmes de colágeno apresentaram barreira até, aproximadamente, 250nm (Figura 50). Os filmes de gelatina adicionados de extrato de boldo-do-Chile ofereceram barreira UV até 300nm, assim como os filmes de colágeno sem extrato de boldo-do-Chile. Os filmes de colágeno adicionados que continham extrato de boldo-do-Chile apresentaram barreira até próximo ao início da região da radiação visível ( 390nm).

De maneira geral os filmes de colágeno, apresentaram menores valores de transmitância que os filmes de gelatina, em todo o espectro UV/Visível, independente da concentração de extrato de boldo-do-Chile adicionada. Isso pode ser atribuído a opacidade dos filmes de colágeno, que de certa forma já oferecem uma barreira à radiação UV/Visível.

Contudo, a incorporação do extrato de boldo-do-Chile diminuiu os valores de transmitância na região do UV/Visível quando comparados às formulações controle (Figura 50). Os filmes adicionados de extrato de boldo apresentaram menores valores de transmitância em toda faixa espectral analisada, indicando que a adição do extrato promove uma melhoria na propriedade de barreira UV/Visível dos filmes.

Esse incremento na barreira da radiação UV/Visível pode ser atribuído à presença de compostos fenólicos contidos no extrato de boldo, esses compostos possuem em sua estrutura insaturações que são responsáveis pela absorção da luz na faixa do UV/Visível (BITENCOURT et al., 2014; GÓMEZ-ESTACA et al., 2009a). Além disso, o incremento na propriedade de barreira UV/Visível dos filmes de gelatina e colágeno sugere que estes podem ser utilizados como embalagens alimentícias pois o uso destes materiais pode impedir aceleração da oxidação lipídica através da luz. 
Figura 50: Propriedades de barreira UV/Visível dos filmes de gelatina $(\mathrm{G})$ e colágeno $(\mathrm{C})$ produzidos com diferentes concentrações de extrato de boldo

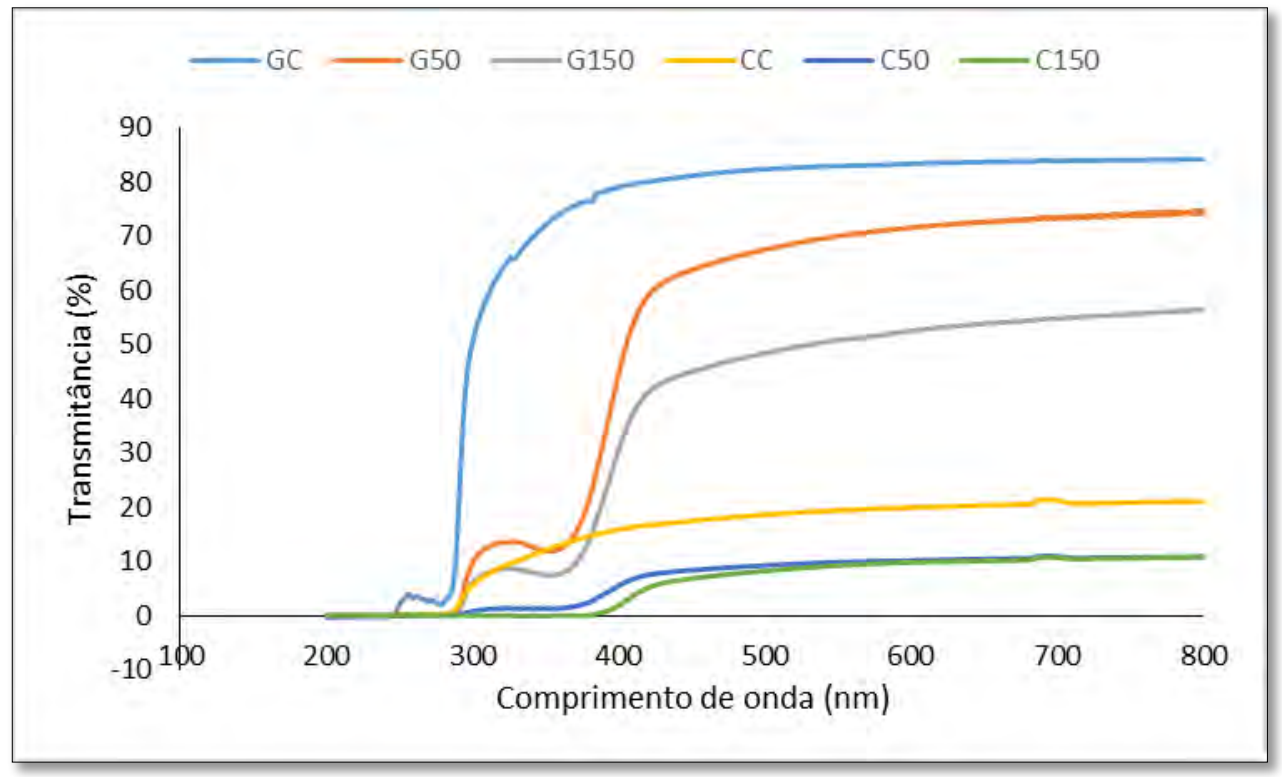

Fonte: Própria autoria

GC: Filme de gelatina sem extrato de boldo; G50: Filme de gelatina contendo 50g de extrato de boldo/100g de gelatina; G150: Filme de gelatina contendo $150 \mathrm{~g}$ de extrato de boldo/100g de gelatina; CC: Filme de colágeno sem extrato de boldo; C50: Filme de colágeno contendo 50g de extrato de boldo/100g de colágeno; C150: Filme de colágeno contendo $150 \mathrm{~g}$ de extrato de boldo/100g de colágeno.

Os resultados obtidos nesta tese estão em consonância com os resultados apresentados por Bitencourt et al. (2014), que estudaram filmes de gelatina adicionados de extrato etanólico de cúrcuma e obtiveram redução da transmitância com o aumento da adição do extrato nos filmes. O mesmo comportamento foi encontrado por Gómez-Estaca et al (2009a) que estudaram filmes de gelatina de peixe e de gelatina bovina incorporados de extratos aquosos de orégano e alecrim, onde também a adição do extrato aumentou a barreira UV/Visível dos filmes. Wu et al. (2013) estudaram filmes de gelatina de peixe adicionados de extrato aquoso de chá verde e também reportaram que o aumento da concentração do extrato nos filmes implicou em uma diminuição da transmitância, sobretudo no intervalo de 200-350nm. 


\subsubsection{Atividade antioxidante dos filmes}

A atividade antioxidante dos filmes foi medida avaliando-se a capacidade dos filmes em inibir o radial ABTS. A adição do extrato de boldo apresentou efeito significativo $(\mathrm{p}<0,05)$ sobre a atividade antioxidantes dos filmes (Figura 51). O aumento da concentração do extrato de boldo nos filmes implicou em um aumento na porcentagem de inibição do radical ABTS. As formulações que não tiveram o extrato de boldo em sua produção (controle) não apresentaram atividade antioxidante frente ao radical ABTS, independente da macromolécula utilizada (Figura 51).

Quando comparados os filmes produzidos com gelatina com aqueles produzidos com colágeno, observou-se que os filmes de gelatina apresentaram maior capacidade inibitória que os filmes de colágeno $(\mathrm{p}<0,05)$, sobretudo para a formulação com $150 \mathrm{~g}$ de extrato de boldo/100g de macromoléculas. Lemańska et al. (2001) e Altunkaya, Gökmen e Skibsted (2016) relataram que a atividades antioxidante de compostos fenólicos mostrou-se reduzida em meios ácidos. Essa hipótese que pode explicar a diferença entre a atividade antioxidante dos filmes de gelatina e colágeno é a diminuição do poder antioxidante dos compostos fenólicos em meio ácido. A solução de colágeno, no momento da adição do extrato de boldo, tinha $\mathrm{pH}$ 3,0 dessa forma, os compostos fenólicos podem ter tido atividade antioxidante reduzida. 
Figura 51: Resposta para a inibição do reagente ABTS em relação à concentração de extrato de boldo-do-Chile adicionado aos filmes de $\bigcirc$ gelatina e $\bigcirc$ colágeno

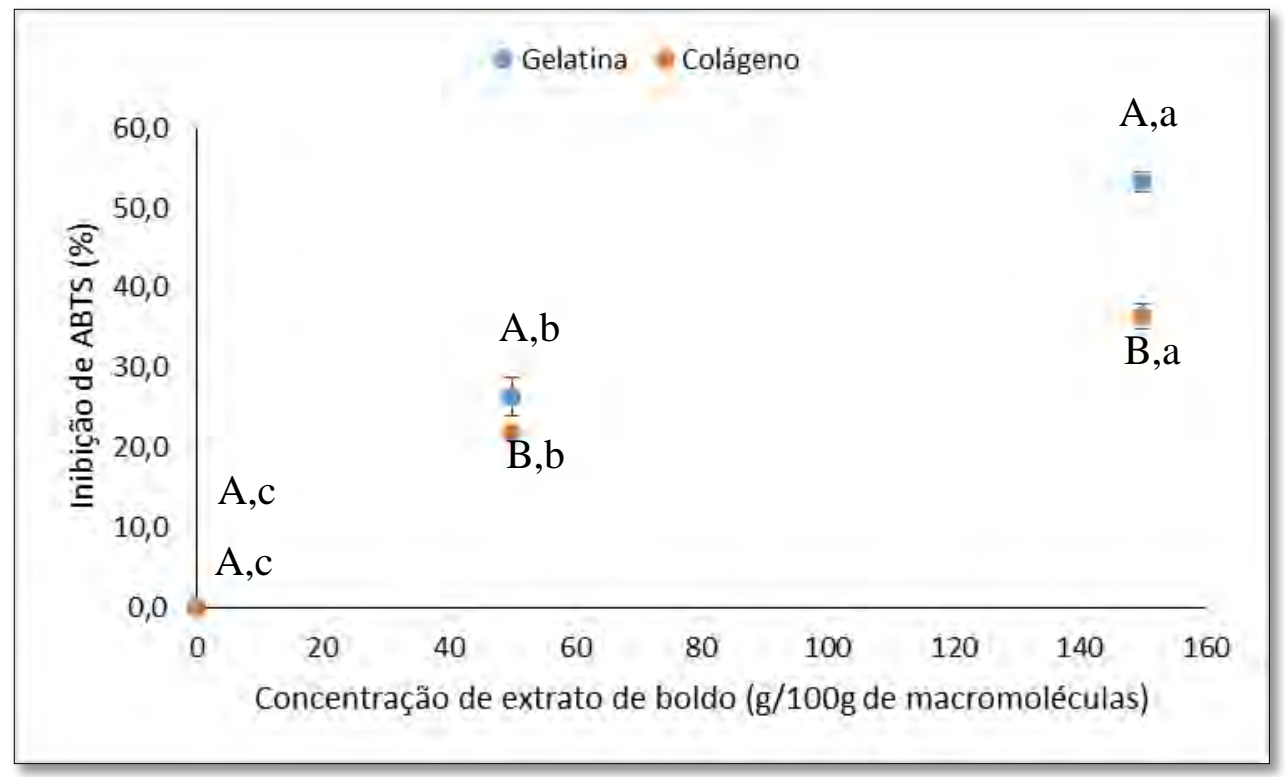

Fonte: Própria autoria

0: formulação sem extrato de boldo-do-Chile; 50: formulação com $50 \mathrm{~g}$ de extrato de boldo-doChile/100g de macromoléculas; 150: formulação com 150g de extrato de boldo-do-Chile/100g de macromoléculas.

A,B letras maiúsculas diferentes para diferentes macromoléculas indicam diferença significativa para o mesmo parâmetro.

a,b letras minúsculas diferentes para diferentes concentrações de extrato de boldo-do-Chile indicam diferença significativa para o mesmo parâmetro.

Filmes de gelatina adicionados de extrato de cúrcuma também apresentaram atividade antioxidante frente ao radical ABTS, e da mesma forma que neste estudo, o aumento da concentração do extrato também implicou em uma maior atividade antioxidante (BITENCOURT et al. 2014). Também foi relatada atividade antioxidante pelo método ABTS nos filmes de HPMC aditivados com NRC, que é um extrato comercial oriundo da beterraba (AKHTAR et al., 2012). Moradi et al. (2012) reportaram a inibição do radical ABTS em filmes em filmes de quitosana adicionados de extrato de semente de uva constatando que os filmes apresentavam atividade antioxidante. Goméz-Guillén et al. (2007) também produziram filmes de gelatina adicionados de extrato aquoso de murta que possuíam atividade antioxidante. 


\section{Conclusões}

Os resultados obtidos nessa tese permitem concluir que o extrato aquoso de boldodo-Chile possui propriedades antioxidantes, sendo que o intervalo de temperatura de extração compreendido entre 45 e $90^{\circ} \mathrm{C}$ implicou em extratos com maior potencial antioxidante. Os resultados da análise de UHPLC-MS foram bastante abrangentes permitindo a identificação de muitos compostos fenólicos como alcaloides e flavonoides, fornecendo assim uma caracterização satisfatória do extrato de boldo-do-Chile produzido neste estudo.

Com relação às propriedades das soluções filmogênicas, a hetereogeneidade da solução de colágeno não permitiu a execução das mesmas análises realizadas para a solução de gelatina, impossibilitado a comparação entre as diferentes macromoléculas. Não foi possível correlacionar os resultados obtidos para as análises térmicas das soluções filmogênicas (SF) e as análises reológicas, com exceção da temperatura de transição gel-sol que foi semelhante em ambas as análises. As informações obtidas nas análises térmicas das SF mostraram que a adição do extrato foi capaz de modificar as propriedades térmicas das mesmas quando a solução foi mantida em baixas temperaturas por longos intervalos de tempo.

Os filmes produzidos com gelatina e colágeno adicionados de extratos aquosos de boldo-do-Chile, quando comparados à formulação controle, mantiveram alguns parâmetros inalterados, ou seja, a adição do extrato não apresentou influência sobre as propriedades mecânicas, a solubilidade, a umidade, a cristalinidade, a permeabilidade ao vapor de água. As análises térmicas dos filmes de gelatina também não foram influenciadas pela adição do referido extrato, no entanto, os filmes de colágeno quando adicionado do extrato de boldodo-Chile, tiveram valores de entalpia de fusão e temperatura de fusão aumentados, indicando uma possível estabilização das cadeias polipeptídicas do colágeno pelos compostos fenólicos contidos no extrato. Entretanto, as análises de espectroscopia de infravermelho com transformada de Fourier apontaram que não houve aparecimento de novas ligações.

Por outro lado, as propriedades óticas e de barreira UV/Visível foram influenciadas pela adição do extrato de boldo-do-Chile, tanto para os filmes de colágeno como para os filmes de gelatina. $\mathrm{O}$ extrato de boldo-do-Chile conferiu uma coloração amarelada aos filmes, e aumentou as propriedades de barreira UV/Visível sugerindo que os filmes produzidos podem diminuir a oxidação lipídica por oferecerem uma barreira à luminosidade. 
As propriedades de superfície dos filmes de gelatina mostraram-se bastante homogêneas, lisas e brilhantes em ambos os lados. Já nos filmes de colágeno, a superfície de secagem mostrou-se bastante rugosa, ao passo que a superfície em contato com a placa era lisa e brilhante.

O ângulo de contato dos filmes também confirmou a diferença entre os lados dos filmes para ambas macromoléculas, além disso, a adição do extrato de boldo diminuiu o ângulo de contato dos filmes, provavelmente pela presença de grupamentos polares nos compostos do extrato de boldo-do-Chile.

Por fim, os filmes adicionados do extrato de boldo-do-Chile apresentaram atividade antioxidante frente ao radical ABTS, e foi possível constatar que o incremento da concentração do extrato de boldo-do-Chile aumentou o potencial antioxidante dos filmes.

Dessa forma, concluiu-se que apesar da adição do extrato de boldo-do-Chile não ter provocado melhorias em algumas das propriedades físicas estudadas neste trabalho, os filmes aditivados com o extrato em questão apresentaram boas propriedades de barreira UV/Visível e atividade antioxidante, podendo então ser considerados filmes ativos. 


\section{Referências Bibliográficas}

AKHTAR, M.J. et al. Antioxidant capacity and light-aging study of HPMC films functionalized with natural plant extract. Carbohydrate Polymers, Barking, Inglaterra, GB, v. 89, p.1150- 1158, 2012

AKHTAR, M.-J. et al. Fabrication and physicochemical characterization of HPMC films with commercial plant extract: Influence of light and film composition. Food Hydrocolloids, Oxford, Inglaterra, GB, v.31, p.420-427, 2013.

ALARCÓN, E. et al. Antioxidant capacity of herbal infusions and tea extracts: A comparison of ORAC-fluorescein and ORAC-pyrogallol red methodologies. Food Chemistry, London, GB, v. 107, p. 1114-1119, 2008.

ALBANO, K.; FRANCO, C.L.; TELIS, V.R.N. Rheological behavior of Peruvian carrot starch gels as affected by temperature and concentration. Food Hydrocolloids, Oxford, Inglaterra, GB, v. 40, p. 30-43, 2014.

ALTUNKAYA, A.; GÖKMEN, V.; SKIBSTED, L.H. pH dependent antioxidant activity of lettuce (L. sativa) and synergism with added phenolic antioxidants. Food Chemistry, London, GB, v. 190, p. 25-32, 2016.

ALVES, P.M.A. et al. Development of films based on blends of gelatin and poly(vinyl alcohol) cross linked with glutaralhehyde. Food Hydrocolloids, Oxford, Inglaterra, GB, v.25, p.1751-1757, 2011.

ANGELE, P. et al. Influence of different collagen species on physico-chemical properties of crosslinked collagen matrices. Biomaterials, Surrey, Inglaterra, GB, v. 25, n. 14, p. 2831-2841, 2004.

AOAC, ASSOCIATION OF OFFICIAL ANALYTICAL CHEMISTS. Official methods of analysis. 16. ed. Arlington: AOAC, 1995.

ARVANITOYANNIS, I.; BILIADERIS, C.G. Physical properties of polyol-plasticized edible blends made of methylcellulose and soluble starch. Carbohydrate Polymers, Barking, Inglaterra, GB, v. 38, n. 1, p. 47-58, 1999.

ARVANITOYANNIS, I.S. Formation and Properties of collagen and gelatin films and coatings. In: GENNADIOS, A. (Ed.), Protein-based films and coatings. CRC Press, p.275-304, 2002.

ASTM. American Society for Testing Materials. Standard test method for water vapor transmission of materials. Annual book of ASTM standards. Designation E96/96M. Philadelphia: American Society for Testing Materials, 2010a.

ASTM. Standard practice for calculation of color tolerances and color differences from instrumentally measured color coordinates. Annual book of ASTM standards.

Designation D2244 - 11. Philadelphia: American Society for Testing Materials, 2011. 
ASTM. Standard test method for tensile properties of thin plastic sheeting. Annual book of ASTM standards. Designation D882-10. Philadelphia: American Society for Testing Materials, 2010b.

BARRETO, P.L.M. et al. Effect of concentration, temperature and plasticizer of sodium caseinate and sodium caseinate/sorbitol solutions and glass transition of their films. Food Chemistry, London, GB, v. 82, n. 3, p. 425-431, 2003.

BERGO, P.; MORAES, I.C.F.; SOBRAL, P.J.A. Infrared spectroscopy, mechanical analysis, dielectric properties and microwave response of pigskin gelatin films plasticized with glycerol. Food Bioscience, Amsterdam, Netherlands, v. 1, p. 10-15, 2013.

BERGO, P.; SOBRAL, P.J.A.; Effects of plasticizer on physical properties of pigskin gelatin films. Food Hydrocolloids, Oxford, Inglaterra, GB, v. 21 p. 1285-1289, 2007.

BIFANI, V. et al. Effects of murta (Ugni molinae Turcz) extract on gas and water vapor permeability of carboxymethylcellulose-based edible films. LWT - Food Science and Technology, London, GB, v. 40, p. 1473-1481, 2007.

BIGI, A. et al. Mechanical and thermal properties of gelatin films at different degrees of glutaraldehyde crosslinking. Biomaterials, Surrey, Inglaterra, GB, v. 22, p. 763-768, 2001.

BIGI, A.; PANZAVOLTA, S.; RUBINI, K. Relationship between triple-helix content mechanical properties of gelatin films. Biomaterials, Surrey, Inglaterra, GB, v.25, p. 5675-5680, 2004.

BITENCOURT, C.M. et al. Gelatin-based films additivated with curcuma ethanol extract: Antioxidant activity and physical properties of films. Food Hydrocolloids, Oxford, Inglaterra, GB, v 40, p. 145-152, 2014.

BONDET, V.; BRAND-WILLIANS, W.; BERSET, C. kinetics and mechanisms of antioxidant activity using the DPPH • free radical method. LWT - Food Science and Technology, London, GB, v. 30, p.609-615, 1997.

BRAND-WILLIANS, W.; CUVELLIER, M.E.; BERSET, C. Use of a free radical method to evaluate antioxidant activity. LWT - Food Science and Technology, London, GB, v.28, n.1, p.-25-30, 1995.

BROINIZI, P.R.B. et al. Avaliação da atividade antioxidante dos compostos fenólicos naturalmente presentes em subprodutos do pseudofruto de caju (Anacardium occidentale L.). Ciência e Tecnologia de Alimentos, Campinas, SP, v. 27, n. 4, p. 902-908, 2007.

BUSSEMER, T.; DASHEVSKY, A.; BODMEIER, R. A pulsatile drug delivery system based on rupturable coated hard gelatin capsules. Journal of Controlled Release, Amsterdam, NL, v. 93, p. $331-339,2003$.

CARVALHO, R.A.; GROSSO, C.R.F. Characterization of gelatin based films modified with transglutaminase glyoxal and formaldehyde. Food Hydrocolloids, Oxford, Inglaterra, GB, v. 18, n. 5, p.717-726, 2004. 
CARVALHO, R.A.; GROSSO, C.R.F. Properties of chemically modified gelatin films. Brazilian Journal of Chemical Engineering, São Paulo, SP, v. 23, n.1, p.45-53, 2006.

CASSU, S.N.; FELISBERTI, M.I. Comportamento dinâmico-mecânico e relaxações em polímeros e blendas poliméricas. Química Nova, São Paulo, SP, v. 28, n. 2, p. 255-263, 2005 .

CERQUEIRA, M.A. et al. Seed extracts of Gleditsia triacanthos: Functional properties evaluation and incorporation into galactomannan films. Food Research International, Barking, Inglaterra, GB, v. 43, n. 8, p. 2031-2038, 2010.

CHARULATHA, V.; RAJARAM, A. Influence of different crosslinking treatments on the physical properties of collagen membranes. Biomaterials, Surrey, Inglaterra, GB, v. 24, p. 759-767, 2003.

CHAUDRY, Z.F. et al. Preparação e caracterização de colageno anionico por hidrolise seletiva de grupos carboxamida internos. Polímeros: Ciência e Tecnologia, São Carlos, SP, v. Abr/Jun, p. 40-46, 1997.

CHEN, T. et al. The isolation and identification of two compounds with predominant radical scavenging activity in hempseed (seed of Cannabis sativa L.). Food Chemistry, London, GB, v.134, p. 1030-1037, 2012.

CHO, S.M.; GUB, Y.S.; KIM, S.B. Extracting optimization and physical properties of yellowfin tuna (Thunnus albacares) skin gelatin compared to mammalian gelatins. Food Hydrocolloids, Oxford, Inglaterra, GB, v. 19, p. 221-229, 2005.

CIELAB. Representação do sólido de cores. Disponível em:< http://dba.med.sc.edu/price/irf/Adobe_tg/models/cielab.html.>. Acesso em: 29 de setembro de 2015.

COLLIN, S. et al. Chapitre 1 : Nomenclature et voies de synthèses des principaux polyphénols. In: COLLIN, S.; CROUZET, J. Polyphénols et procédés. Lavoisier, p. 5-27, 2011

CONCA, K.R. Chapter 23 Protein- Based Films And Coatings For Military Packaging Applications. In: GENNADIOS, A. Protein-Based Films and Coatings. DOI: 10.1201/9781420031980.ch23, CRCPress, 2002.

DEIBER, J.A.; PEIROTTI, M.B.; OTTONE, M.L. Rheological characterization of edible films made from collagen colloidal particle suspensions. Food Hydrocolloids, Oxford, Inglaterra, GB, v. 25, p. 1382-1392, 2011.

DEL RÉ, P.V.; JORGE, N. Especiarias como antioxidantes naturais: aplicações em alimentos e implicação na saúde. Revista Brasileira de Plantas Medicinais, Botucatu, SP, v.14, n.2, p 389-399, 2012.

DEL VALLE, J.M. et al. Extraction of boldo (Peumus boldus M.) leaves with supercritical $\mathrm{CO} 2$ and hot pressurized water. Food Research International, Barking, Inglaterra, GB, v. 38, p. 203-213, 2005. 
DEL VALLE, J.M. et al. Recovery of antioxidants from boldo (Peumus boldus M.) by conventional and supercritical CO2 extraction. Food Research International, Barking, Inglaterra, GB, v. 37, p.695-702, 2004.

DÍAZ-CALDERÓN, P. et al. Molecular configuration of gelatin water suspensions at low concentration. Food Hydrocolloids, Oxford, Inglaterra, GB, v. 39, p. 171-179, 2014.

DING, C.; ZHANG, M.; LI, G. Preparation and characterization of collagen/hydroxypropyl methylcellulose (HPMC) blend film. Carbohydrate Polymers, Barking, Inglaterra, GB, v. 119, p. 194-201, 2015.

DONG, Z.; WANG, Q.; DU, Y. Alginate/gelatin blend films and their properties for drug controlled release. Journal of Membrane Science, Amsterdam, NL, v. 280, p. 37-44, 2006.

DUARTE, M.C.T. et al. Activity of essential oils from Brazilian medicinal plants on Escherichia coli. Journal of Ethnopharmacology, Lausanne, Suica, CH, v. 111, n. 2, p. 197-201, 2007.

EASYRGB. Disponível em: <http://www.easyrgb.com/index.php?X=CALC>. Acesso em: 03 de outubro de 2015.

EYSTURSKARĐ, J. et al. Mechanical properties of mammalian and fish gelatins based on their weight average molecular weight and molecular weight distribution. Food Hydrocolloids, Oxford, Inglaterra, GB, v. 23, p. 2315-2321, 2009.

FALÉ, P.L. et al. Acetylcholinesterase inhibition, antioxidant activity and toxicity of Peumus boldus water extracts on HeLa and Caco-2 cell lines. Food and Chemical Toxicology, Oxford, Inglaterra, GB, v. 50, p. 2656-2662, 2012.

FANG, Y. et al. Tensile and barrier properties of edible films made from whey proteins. Journal of Food Science, Chicago, Ill., US, v. 67, n. 1, p. 188-193, 2002.

FIGUEIRÓ, S.D. et al. On the physico-chemical and dielectric properties of glutaraldehyde crosslinked galactomannan-collagen films. Carbohydrate Polymers, Barking, Inglaterra, GB, v. 56, p. 313-320, 2004.

FITZSIMONS, S.M.; MULVIHILL, D.M.; MORRIS, E.R. Segregative interactions between gelatin and polymerized whey protein. Food Hydrocolloids, Oxford, Inglaterra, GB, v.2, p.485-492, 2008.

FRIESS, W. Collagen - biomaterial for drug delivery. European Journal of Pharmaceutics and Biopharmaceutics, London, GB, v. 45, p. 113 - 136, 1998.

GALIETTA, G. et al. Mechanical and Thermomechanical Properties of Films Based on Whey Proteins as Affected by Plasticizer and Crosslinking Agents. Journal of Dairy Science, Champaign, III., US, v. 81, n. 12, p. 3123-3130, 1998. 
GERMAN, J.B. Chapter 18: Antioxidants. In: THORNGATE III, J.H.; SALMINEN, S.; BRANEN, L.A.; DAVIDSON, M.P. (Eds). Food Additives, DOI: 10.1201/9780824741709.ch18, CRC Press, 2002.

GIMÉNEZ, B. et al. Release of active compounds from agar and agar-gelatin films with green tea extract. Food Hydrocolloids, Oxford, Inglaterra, GB, v. 30, n. 1, p. 264-271, 2013.

GÓMEZ-ESTACA, J. et al. Antioxidant properties of tuna-skin and bovine-hide gelatin films induced by the addition of oregano and rosemary extracts. Food Chemistry, London, GB, v. 112, p. 18-25, 2009a.

GÓMEZ-ESTACA, J. et al. Effect of functional edible films and high pressure processing on microbial and oxidative spoilage in cold-smoked sardine (Sardina pilchardus). Food Chemistry, London, GB, v. 105, n. 2, p. 18-25, 2007.

GÓMEZ-ESTACA, J. et al. Incorporation of antioxidant borage extract into edible films based on sole skin gelatin or a commercial fish gelatin. Journal of Food Engineering, Essex, Inglaterra, GB, v. 92, p. 78-85, 2009b.

GÓMEZ-ESTACA, J. et al. Physical and chemical properties of tuna-skin and bovine-hide gelatin films with added aqueous oregano and rosemary extracts. Food Hydrocolloids, Oxford, Inglaterra, GB, v. 23, p.1334-1341, 2009c.

GÓMEZ-ESTACA, J. et al. Physico-chemical and film-forming properties of bovine-hide and tuna-skin gelatin: A comparative study. Journal of Food Engineering, Essex, Inglaterra, GB, v.90, p. 480-486, 2009 d.

GÓMEZ-GUILLÉN, M.C. et al. Edible films made from tuna-fish gelatin with antioxidant extracts of two different murta ecotypes leaves (Ugni molinae Turcz). Food

Hydrocolloids, Oxford, Inglaterra, GB, v.21, p. 1133-1143, 2007.

GÓMEZ-GUILLÉN, M.C. et al. Functional and bioactive properties of collagen and gelatin from alternative sources: A review. Food Hydrocolloids, Oxford, Inglaterra, GB, v. 25, p. 1813-1827, 2011.

GONTARD, N. Panorama des emballages alimentaires actifs. In: GONTARD, N. (Ed.) Les emballages actifs, p.1, Tec \& Doc, 2000.

GONTARD, N.; GUILBERT, S.; CUQ, J.L. Edible wheat gluten films: influence of the main process variables on film properties using response surface methodology. Journal of Food Science, Chicago, III., US, v. 57, p. 190-195, 1992.

GOUNGA, M.E.; XU, S.-Y.; WANG, Z.; Whey protein isolate-based edible films as affected by protein concentration, glycerol ratio and pullulan addition in film formation. Journal of Food Engineering, Essex, Inglaterra, GB, v. 83, n. 4, p. 521-530, 2007.

GROVER, C.N. et al. Crosslinking and composition influence the surface properties, mechanical stiffness and cell reactivity of collagen-based films. Acta Biomaterialia, Amsterdam, Netherlands v. 8, p. 3080-3090, 2012. 
GUTIERREZ, M.Q. et al. Carboxymethylcellulose-montmorillonite nanocomposite films activated with murta (Ugni molinae Turcz) leaves extract. Carbohydrate Polymers, Barking, Inglaterra, GB, v. 87, n 2, p.1495-1502, 2012.

HAGEN, S.R.; FROST, B.; AUGUSTIN, J. Precolumn phenylisothiocyanate derivatization and liquid chromatography of amino acids in food. Journal of the Association of Official Analytical Chemists (JAOAC), Rockville, USA v.72, n.6, p. 912916, 1989.

HALLIWELL, B. Chapter 1: Food-derived antioxidants: how to evaluate their importance in food and in vivo. In: CADENAS, E.; PACKER, L. Handbook of Antioxidants, DOI: 10.1201/9780203904046.pt1, CRC Press, 2001.

HE, L. et al. Modification of collagen with a natural cross-linker, procyanidin.

International Journal of Biological Macromolecules, Guildford, Inglaterra, GB, v. 48, p. 354-359, 2011.

HELLIO- SERUGHETTI, D.; DJABOUROV, M. Gelatin hydrogels cross-linked with bis(vinylsulfonyl)methane (BVSM):1. The Chemical Networks. Langmuir, Washington, US, v.22, p. 8509-8515, 2006a.

HELLIO-SERUGHETTI, D.; DJABOUROV, M. Gelatin hydrogels cross-linked with Bisvinyl Sulfonemethyl. 2. The physical and chemical networks. Langmuir, Washington, US, v.22, 8516-8522, $2006 \mathrm{~b}$.

HONG, S. I.; KROCHTA, J. M. Oxygen barrier performance of whey-proteincoated plastic films as affected by temperature, relative humidity, base film and protein type. Journal of Food Engineering, Essex, Inglaterra, GB, v.77, p. 739-745, 2006.

HOQUE, M.S.; BENJAKUL, S.; PRODPRAN, T. Properties of film from cuttlefish (Sepia pharaonis) skin gelatin incorporated with cinnamon, clove and star anise extracts. Food Hydrocolloids, Oxford, Inglaterra, GB, v. 25, p. 1085-1097, 2011.

HSU, S.L.C.; CHEN, H.T.; TSAI, S.J. Novel positive-working and aqueousbasedevelopable photosensitive poly (imide benzoxazole) precursor. Journal of Polymer Science, New York, US, v. 42, p. 5990-5998, 2004.

JANSSON, A.; THUVANDER, F. Influence of thickness on the mechanical properties for starch films. Carbohydrate Polymers, Barking, Inglaterra, GB, v. 56, p. 499-503, 2004.

JORGE, M.F.C. Caracterização de filmes nanocompositos biodegradáveis a base de gelatina produzidos com um aplicador automático de filmes. 2012. 137f. Tese (doutorado) - Faculdade de Zootecnia e Engenharia de Alimentos, Universidade de São Paulo, Pirassununga, 2012.

JORGE, M.F.C. et al. Viscoelastic and rheological properties of nanocomposite-forming solutions based on gelatin and montmorillonite. Journal of Food Engineering, Essex, Inglaterra, GB, v. 120, p. 81-87, 2014. 
KADAM, S.U. et al. Development of biopolymer-based gelatin and casein films incorporating brown seaweed Ascophyllum nodosum extract. Food Packaging and Shelf Life, Amsterdam, Netherlands, v. 6, p. 68-74, 2015.

KALMAN, D.S.; Gelatin, Ch7, p.105-113. In: WOLINSKY, I.; DRISKELL, J.A. Nutritional Ergogenic Aids, DOI: 10.1201/9780203507704.ch7, 2004.

KALOGEROPOULOS, N.; CHIOU, A. Chapter 18: Antioxidants. In: NOLLET, L.M.L.; TOLDRÁ, F. (Ed), Handbook of Seafood and Seafood Products Analysis, p. 309-326, CRC Press, 2009.

KARBOWIAK, T.; DEBEAUFORT, F.; VOILLEY, A. Importance of surface tension characterization for fodd, pharmaceutical and packaging products: a review. Critical Reviews in Food Science and Nutrition, Boca Raton, Fla., US, v. 46, p. 391-407, 2006.

KHOSHGOZARAN-ABRAS, S. et al. Mechanical, physicochemical and color properties of chitosan based-films as a function of Aloe vera gel incorporation. Carbohydrate Polymers, Barking, Inglaterra, GB, v. 87, p. 2058-2062, 2012.

KIM, D.; MIN, S.C., Trout skin gelatin-based edible film development. Journal of Food Science, Chicago, Ill., USA, v. 77, p. E240-E246, 2012.

KROCHTA, J.M. Chapter 1. Proteins as Raw Materials for Films and Coatings: Definitions, Current Status, and Opportunities. In: GENNADIOS, A. Protein-Based Films and Coatings. DOI: 10.1201/9781420031980.ch1, CRC Press 2002

LEE, H.S. Phenolic compounds in foods. In: NOLLET, L.M.L (Ed.), Handbook of Food Analysis. Second Edition, CRC Press, p. 657-715, 2004.

LEMAŃSKA, $\mathrm{K}$. et al. The influence of $\mathrm{pH}$ on antioxidant properties and the mechanism of antioxidant action of hydroxyflavones. Free Radical Biology \& Medicine, New York, US, v. 31, n. 7, p. 869-881, 2001.

LENS, J.-P. et al. Influence of processing and storage conditions on the mechanical and barrier properties of films cast from aqueous wheat gluten dispersions. Industrial Crops and Products, Amsterdam, Netherlands, v. 17, n. 2, p. 119-130, 2003.

LI, J.-H. et al. Preparation and characterization of active gelatin-based films incorporated with natural antioxidants. Food Hydrocolloids, Oxford, Inglaterra, GB, v.37, p. 166-173, 2014.

LIMA, C.G.A. et al. DC conductivity and dielectric permittivity of collagen-chitosan films. Materials Chemistry and Physics, Lausanne, Suica, CH, v.99, p. 284-288, 2006.

LÓPEZ-RUBIO, A. et al. Overview of active polymer-based packaging technologies for food applications. Food Reviews International, New York, US, v. 20, n. 4, p. 357-387, 2004.

MACHEIX, J.-J.; FLEURIET, A.; SARNI-MANCHADO, P. Chapitre 1: Composés phénoliques dans la plante - Structure, biosynthèse, répartition et rôles. In: SARNI- 
MANCHADO, P.; CHEYNIER, V (Ed.), Les polyphénols en agroalimentaire. Lavoisier, p. $1-28,2006$.

MAIA, L.H.; PORTE, A.; SOUZA, V.F. Filmes comestíveis: Aspectos gerais, propriedades de barreira à umidade e oxigênio. Boletim CEPPA, v. 18, p. 105-128, 2000.

MAKISHI, G.L.A. et al. Films based on castor bean (Ricinus communis L.) proteins crosslinked with glutaraldehyde and glyoxal. Industrial Crops and Products, Amsterdam, Netherlands, v. 50, p. 375-382, 2013.

MARCOS, B. et al. Development of biodegradable films with antioxidant properties based on polyesters containing a-tocopherol and olive leaf extract for food packaging applications. Food Packaging and Shelf Life, Amsterdam, Netherlands, v. 1, p. 140-150, 2014.

MARCUZZO, E. et al. Effect of ultrasound treatment on properties of gluten-based film. Innovative Food Science and Emerging Technologies, Amsterdam, NL, v. 11, p. 451457, 2010.

MARQUIE, C. et al. Biodegradable packaging made from cottonseed flour: formation and improvement by chemical treatments with gossypol, formaldehyde, and glutaraldehyde. Journal of Agricultural and Food Chemistry, Easton, Pa., US, v. 43, n. 10, p. 27622767, 1995.

MARTIN,J.G. Antimicrobial potencial and chemical compositions of agro-industrial wastes. Journal of Natural Products, Cincinnati, Ohio, US, v. 5, p. 527- 536, 2012.

MATSUBARA, S.; RODRIGUEZ-AMAYA, D.B. Conteúdo de mircetina, quercetina e kaempferol em chás comercializados no Brasil. Ciência e Tecnologia de Alimentos, Campinas, SP, v. 26, p. 380-385, 2006.

MOLYNEUX, P. The use of the stable free radical diphenylpicrylhydrazyl (DPPH) for estimating antioxidant activity. Songklanakarin Journal of Food Science and Technology, Hat Yai, Songkhla ,Thailand, v. 26, n. 2, p. 211-219, 2004.

MORADI, M. et al. Characterization of antioxidant chitosan film incorporated with Zataria multiflora Boiss essential oil and grape seed extract. LWT - Food Science and Technology, London, GB, v. 46, n.2, p. 477-484, 2012.

MORAES, I.C.F. et al. Film forming solutions based on gelatin and poly(vinyl alcohol) blends: Thermal and rheological characterizations. Journal of Food Engineering, Essex, Inglaterra, GB, v. 95, p. 588-596, 2009.

MORAIS, S.M. et al. Ação antioxidante de chás e condimentos de grande consumo no Brasil. Revista Brasileira de Farmacognosia, São Paulo, SP, v. 19, p. 315-320, 2009.

MUKHOPADHYAY, M. Chapter 8: Natural Antioxidants. In: MUKHOPADHYAY, M. (Ed), Natural Extracts Using Supercritical Carbon Dioxide, CRC Press, p. 225-248, 2000 . 
MUNIZ, L.B.; MATTOS, L.M.; MORETTI, C.L. Protocolo de avaliação da qualidade física e química de cebola. Comunicado Técnico EMBRAPA, n. 83, 5p., ISSN: 1414.9850, outubro, 2012.

MUÑOZ-VELÁZQUEZ, E.E. et al. Conparción del contenido fenólico, capacidad antioxidante y actividad antiinflamatoria de infusionesherbales comerciales. Revista Mexicana de Ciencias Agrícolas, México, MX, v.3, p481-495, 2012.

NAKATANI, N. Chapter 4: Antioxidantes from spices and herbs. IN: SHAHIDI, F. (Ed.) Natural antioxidants: Chemistry, health effects, and applications, p. 64-75, The American Oil Chemists Society, 1997.

NEVES, L.C.; ALENCAR, S.M.; CARPES, S.T. Determinação da atividade antioxidante e do teor de compostos fenólicos e flavonoides totais em amostras de pólen apícola de Apis melífera. Brazilian Journal of Food Technology, Campinas, SP, junho, p. 107-110, 2009.

NORAJIT, K.; KIM, K.M.; RYU, G.H. Comparative studies on characterization and antioxidante properties of biodegradable alginate films containing ginseng extract. Journal of Food Engineering, Essex, Inglaterra, GB, v. 98, n. 3, p. 377-384, 2010.

O'BRIEN, P.; CARRASCO-POZO, C.; SPEISKY, H. Boldine and its antioxidant or health-promoting properties. Chemico-Biological Interactions, Limerick, Irlanda, IE, v. 159, p. 1-17, 2006.

OLIVEIRA, A.C.et al. Fontes vegetais naturais de antioxidantes. Química Nova, São Paulo, SP, v, 32, n. 3, p. 689-702, 2009.

OSBURN, W.N. Chapter 17: Collagen Casings. In: GENNADIOS, A. (Ed) Protein-Based Films and Coatings. DOI:10.1201/9781420031980.ch17, CRC Press, p.445-466, 2002

OSÉS, J. et al. Stability of the mechanical properties of edible films based on whey protein isolate during storage at different relative humidity. Food Hydrocolloids, Oxford, Inglaterra, GB, v. 23, n. 1, p. 125-131, 2009.

PERESSINI, D. et al. Starch-methylcellulose based edible films: rheological properties of film-forming dispersions. Journal of Food Engineering, Essex, Inglaterra, GB, v. 59, p. 25-32, 2003.

PÉREZ-GAGO, M.B. Chapter 2. Protein-based films and coatings. In: BAI, J. (Ed) Edible Coatings and Films to Improve Food Quality, p. 13-77, CRC Press 2011.

PERSIKOV, A.V. et al. Amino acid propensities for the collagen triple-helix.

Biochemistry, Washington, DC, v. 39, n. 48, p.14960-14967, 2000.

PRADO, A. Composição fenólica e atividade antioxidante de frutas tropicais. 2009. 107f. Dissertação (Mestrado) - Escola Superior de Agricultura Luiz de Queiroz, Universidade de São Paulo, Piracicaba, 2009. 
QUEZADA, N. et al. Antioxidant activity of crude extract, alkaloid fraction, and flavonoid fraction from boldo (Peumus boldus Molina) leaves. Journal of Food Science, Chicago, Ill., US, v. 69, n. 5, p. C.371-C.376, 2004.

RAMALHO, V.C.; JORGE, N. Antioxidantes utilizados em óleos, gorduras e alimentos gordurosos. Química Nova, São Paulo, SP, v. 29, n. 4, p. 755-760, 2006

RATANAVARAPORN, J. et al. Influences of physical and chemical crosslinking techniques on electrospun type A and B gelatin fiber mats. International Journal of Biological Macromolecules, Guildford, Inglaterra, GB, v. 47, p. 431-438, 2010.

RATTAYA, S.; BENJAKUL, S.; PRODPRAN, T. Properties of fish skin gelatin film incorporated with seaweed extract. Journal of Food Engineering, Essex, Inglaterra, GB, v. 95, p. 151-157, 2009.

RE, R. et al. Antioxidant Activity Applying An Improved Abts Radical Cation Decolorization Assay. Free Radical Biology \& Medicine, New York, US, v. 26, n. 9/10, p. 1231-1237, 1999.

REISCHE, D.W.; LILLARD, D.A.; EITENMILLER, R.R.; Chapter 15: Antioxidants. In: AKOH, C.C.; MIN, D.B. (Eds.). Food lipids - Chemistry, nutrition, and biotechnology, p. 409-433, Third Edition, CRC Press, 2008.

RIVERO, S.; GARCÍA, M.A.; PINOTTI, A. Correlations between structural, barrier, thermal and mechanical properties of plasticized gelatin films. Innovative Food Science and Emerging Technologies, Amsterdam, NL, v. 11, p. 369-375, 2010.

ROHN, S. Possibilities and limitations in the analysis of covalent interactions between phenolic compounds and proteins. Food Research International, Barking, Inglaterra, GB, v. 65, p. 13-19, 2014.

RUFINO,M.M. et al. Metodologia científica: Determinação da atividade antioxidante total em frutas pela captura do radical livre $\mathrm{ABTS}^{\cdot+}$. Comunicado Técnico EMBRAPA, n. 128, 4p., ISSN 1679-6535, julho, 2007.

RUIZ, A.L.T.G. et al. Farmacologia e Toxicologia de Peumus boldus e Baccharis genistelloides. Revista Brasileira de Farmacognosia, São Paulo, SP, v. 18, n. 2, p. 295 300, 2008.

SARBON, N.M.; BADII, F.; HOWELL, N.K. The effect of chicken skin gelatin and whey protein interactions on rheological and thermal properties. Food Hydrocolloids, Oxford, Inglaterra, GB, v. 45, p. 83-92, 2015.

SCHMEDA-HIRSCHMANN, G. et al. Free-radical scavengers and antioxidants from Peumus boldus Mol. ("Boldo"). Free Radical Research, London, GB, v. 37, n. 4, p. 447452, 2003.

SHAHIDI, F. Chapter 1: Natural Oxidants: An Overview. In: SHAHIDI, F. (Ed.) Natural antioxidants: Chemistry, health effects, and applications, p. 1-11, The American Oil Chemists Society, 1997. 
SHAHIDI, F.; ZHONG, Y. Chapter 12: Antioxidants: Regulatory status. In: SHAHIDI, F. (Ed). Edible oil and fat products: chemistry, properties, and health effects, vol 1, Bailey's industrial oil and fat products, p. 491-512, Sixth Edition, John Wiley \& Sons, Inc., Publication, 2005.

SILVA, C.C. et al. Effect of the $\mathrm{pH}$ on the piezoelectric properties of collagen films. Materials Science and Engineering: B, Lausanne, Suica, CH, v. 83, n. 1-3, p. 165-172, 2001.

SILVA-WEISS, A. et al. Polyphenol-rich extract from murta leaves on rheological properties of film-forming solutions based on different hydrocolloid blends. Journal of Food Engineering, Essex, Inglaterra, GB, v. 140, p. 28-38, 2014.

SIMIRGIOTIS, M.J.; SCHMEDA-HIRSCHMANN, G. Direct identification of phenolic constituents in Boldo Folium (Peumus boldus Mol.) infusions by high-performance liquid chromatography with diode array detection and electrospray ionization tandem mass spectrometry. Journal of Chromatography A, Amsterdam, NL, v.12171, p. 443-449, 2010.

SINGLETON, V.L.; ROSSI JR, J.A. Colorimetry of total phenolocs with phosphomolybdic-phosphotugstic acid reagents. American Journal of Enology and Viticulture, Davis, Calif., US, p. 144-158, 1965.

SIONKOWSKA, A. et al. Chemical and thermal cross-linking of collagen and elastin hydrolysates. International Journal of Biological Macromolecules, Guildford, Inglaterra, GB, v. 47, p. 570-577, 2010.

SIONKOWSKA, A. Modification of collagen films by ultraviolet irradiation. Polymer Degradation and Stability, Essex, Inglaterra, GB, v. 68, p. 147-151, 2000.

SIRIPATRAWAN, U.; HARTE, B.R. Physical properties and antioxidant activity of an active film from chitosan incorporated with green tea extract. Food Hydrocolloids, Oxford, Inglaterra, GB, v. 24, p.770 - 775, 2010.

SKOOG, D. A.; HOLLER. F. J.; CROUCH, S. R. Principles of Instrumental Analysis. 6. ed. USA: Thomson Brooks/Cole, 2007.

SOBRAL, P. J. A.; HABITANTE, A. M. Q. B. Phase transitions of pigskin gelatin. Food Hydrocolloids, Oxford, Inglaterra, GB, v. 15, n. 4-6, p. 377-382, 2001.

SOBRAL, P.J.A. et al. Mechanical, water vapor barrier and thermal properties of gelatin based edible films. Food Hydrocolloids, Oxford, Inglaterra, GB, v. 15, n. 4-6, p. 423-432, 2001.

SOTO, C. et al. Effect of extraction conditions on total phenolic content and antioxidant capacity of pretreated wild (Peumus boldus) leaves from Chile. Food and Bioproducts Processing, Rugby, Inglaterra, GB, v. 92, p. 328-333, 2014. 
SOUZA, A.C.; DITCHFIELD, C.; TADINI, C.C. Chapter 17:Biodegradable Films Based on Biopolymers for Food Industries. In: PASSOS, M.L.; RIBEIRO, C.P. (Ed.), Innovation in Food Engineering: New Techniques and Products. CRC Press, p. 511-537, 2010.

SPANNEBERG, R. et al. Glyoxal modification of gelatin leads to change in properties of soluçãos and resulting films, Soft Matter, Cambridge, U.K., v. 8, p. 2222-2229, 2012.

SRINIVASA, P.C. et al. Properties of chitosan films prepared under different drying conditions. Journal of Food Engineering, Essex, Inglaterra, GB, v. 63, p. 79-85, 2004.

SRINIVASA, P.C.; RAMESH, M.N.; THARANATHAN, R.N. Effect of plasticizers and fatty acids on mechanical and permeability characteristics of chitosan films. Food Hydrocolloids, Oxford, Inglaterra, GB, v. 21, p. 1113-1122, 2007.

STEVENS, E.S. Green Plastics: An Introduction to the New Science of Biodegradable Plastics, Princeton University Press, New Jersey, 238p., 2002.

SUCUPIRA, N.R. et al. Métodos para determinação da atividade antioxidante de frutos. UNOPAR Cientifíca. Ciências biológicas e da saúde, Londrina, PR, v. 14, n. 4, p. 263 $269,2012$.

SUN, S.; SONG, Y.; ZHENG, Q. Morphologies and properties of thermo-molded biodegradable plastics based on glycerol-plasticized wheat gluten. Food Hydrocolloids, Oxford, Inglaterra, GB, v. 21, n. 7, p. 1005-1013, 2007.

TALJA, R.A. et al. Effect of type and content of binary polyol mixtures on physical and mechanical properties of starch-based edible films. Carbohydrate Polymers, Barking, Inglaterra, GB, v. 71, p. 269-276, 2008.

TANG, L. et al. Physicochemical properties and film-forming ability of fish skin collagen extracted from different freshwater species. Process Biochemistry, London, GB, v. 50, p. $148-155,2015$.

THARANATHAN, R.N. Biodegradable films and composite coatings: past, present and future. Trends in Food Science \& Technology, Cambridge, Inglaterra, GB, v. 14, p.7178, 2003.

THEIVENDRAN, S.; HETTIARACHCHY, N.S.; JOHNSON, M.G. Inhibition of Listeria monocytogenes by Nisin Combined with Grape Seed Extract or Green Tea Extract in Soy Protein Film Coated on Turkey Frankfurters. Journal of Food Science, Chicago, Ill., US, v. 71, p. M39-M44, 2006.

THOMAZINE, M.; CARVALHO, R.A.; SOBRAL, P.J.A. Physical properties of gelatin films plasticized by blends of glycerol and sorbitol. Journal of Food Science, Chicago, Ill., US, v. 70, n.3, p. E172-E176, 2005.

TOMÉ, L.S.C. Preparação e avaliação da permeabilidade de substratos de celulose modificados. 2008. 85f. Dissertação (Mestrado) - Universidade de Aveiro, Aveiro, 2008. 
TORRES, J.A. Edible films and coatings from proteins. In: HETTIARACHY, N.S.; ZIEGLER, G.R. (Ed.). Protein functionality in food systems. New York: M. Dekker, p.467-507, 1994.

TRONCOSO, N. et al. Fast high performance liquid chromatography and ultravioletvisible quantification of principal phenolic antioxidants in fresh rosemary. Journal of Chromatography A, Amsterdam, NL, v.1100, n.1, p.20-25, 2005.

TSERETELI, G.I.; SMIRNOVA, O.I. Calorimetric study of the melting of gelatin gels. Polymer Science, Oxford, Inglaterra, GB, v. 33, n. 10, p. 2112-2118, 1991.

UQUICHE, E. et al. Effect of boldo (Peumus boldus M.) pretreatment on kinetics of supercritical $\mathrm{CO}_{2}$ extraction of essential oil. Journal of Food Engineering, Essex, Inglaterra, GB, v. 109, p. 230-237, 2012.

VALENCIA, G.A. et al. Nanocomposite-forming solutions based on cassava starch and laponite: Viscoelastic and rheological characterization. Journal of Food Engineering, Essex, Inglaterra, v.166, p.174-181, 2015.

VALENTÃO, P. et al. Antioxidative properties of cardoon (Cynara cardunculus L.) infusion against superoxide radical, hydroxyl radical, and hypochlorous acid. Journal of Agricultural and Food Chemistry, Easton, Pa., US, v.50, n.17, p.4989-4993, 2002.

VANIN, F.M. et al. Effects of plasticizers and their concentrations on thermal and functional properties of gelatin-based films. Food Hydrocolloids, Oxford, Inglaterra, GB, v. 19, p. 899-907, 2005.

VAQUERO, M.J.R. et al. Antioxidant capacity and antibacterial activity of phenolic compounds from argentinean herbs infusions. Food Control, Guildford, Inglaterra, GB, v. 21, p. 779-785 2010.

VICENTINI, N.M. et al. Prediction of cassava starch edible film properties by chemometric analysis of infrared spectra. Spectroscopy Letters, New York, US, v. 38, n. 6, p. 749-767, 2005.

VILLALOBOS, R. et al. Gloss and transparency of hydroxypropyl methylcellulose films containing surfactants as affected by their microstructure. Food Hydrocolloids, Oxford, Inglaterra, GB, v. 19, n. 1, p. 53-61, 2005.

VOGLER, E.A. Structure and reactivity of water at biomaterial surfaces. Advances in Colloid and Interface Science, Amsterdam, NL, v. 74, p. 69-117, 1998.

WANASUNDARA, P.K.J.P.D.; SHAHIDI, F. Chapter 11: Antioxidants - Science, technology, and applications. In: In: SHAHIDI, F. (Ed). Edible oil and fat products: chemistry, properties, and health effects, vol 1, Bailey's industrial oil and fat products, p. 431-490, Sixth Edition, John Wiley \& Sons, Inc., Publication, 2005.

WANG, S. et al. Fortification of dietary biopolymers-based packaging material with bioactive plant extracts. Food Research International, Barking, Inglaterra, GB, v. 49, p. 80-91, 2012. 
WOLF, K.L. Propriedades físico-químicas e mecânicas de biofilmes elaborados a partir de fibra e pó de colágeno. 2007. 103f. Dissertação (Mestrado) - Instituto de Biociências, Letras e Ciências Exatas, Universidade Estadual Paulista "Júlio de Mesquita Filho", São José de Rio Preto, 2009.

WOLF, K.L.; SOBRAL, P.J.A.; TELIS, V.R.N. Physicochemical characterization of collagen fibers and collagen powder for self-composite film production. Food Hydrocolloids, Oxford, Inglaterra, GB, v. 23, p. 1886-1894, 2009.

WU, J. et al. Preparation, properties and antioxidant activity of an active film from silver carp (Hypophthalmichthys molitrix) skin gelatin incorporated with green tea extract. Food Hydrocolloids, Oxford, Inglaterra, GB, v. 32, p. 42-51, 2013.

YAKIMETS, I. et al. Mechanical properties with respect to water content of gelatin films in glassy state. Polymer, London, GB, v. 46, p. 12577-12585, 2005.

YAKIMETS, I. et al. Effect of Water Content on the Structural Reorganization and Elastic Properties of Biopolymer Films: A Comparative Study. Biomacromolecules, Washington, US, v. 8, 1710-1722, 2007.

YOON, S.-D.; PARK, M.-H.; BYUN, H.-S. Mechanical and water barrier properties of starch/PVAcomposite films by adding nano-sized poly(methyl methacrylate-coacrylamide) particles. Carbohydrate Polymers, Barking, Inglaterra, GB, v. 87, p.676686, 2012.

ZISMAN, W.A. Relation of the equilibrium contact angle to liquid and solid constitution. Advances in Chemistry Series, Washington, US, v.43 p. 1-51, 1964. 